\title{
Afghanistan News
}

No.. 46

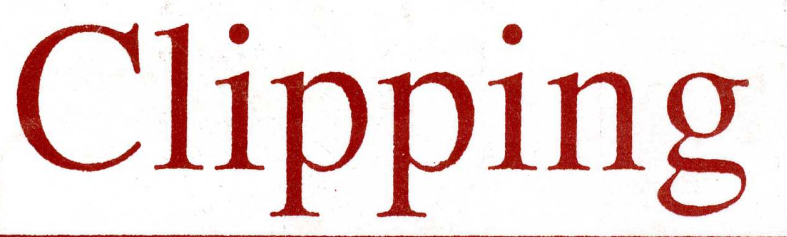

APRIL, 1994

Monthly collection prepared by Afghanistan News Clipping Services

So, Kabul Has
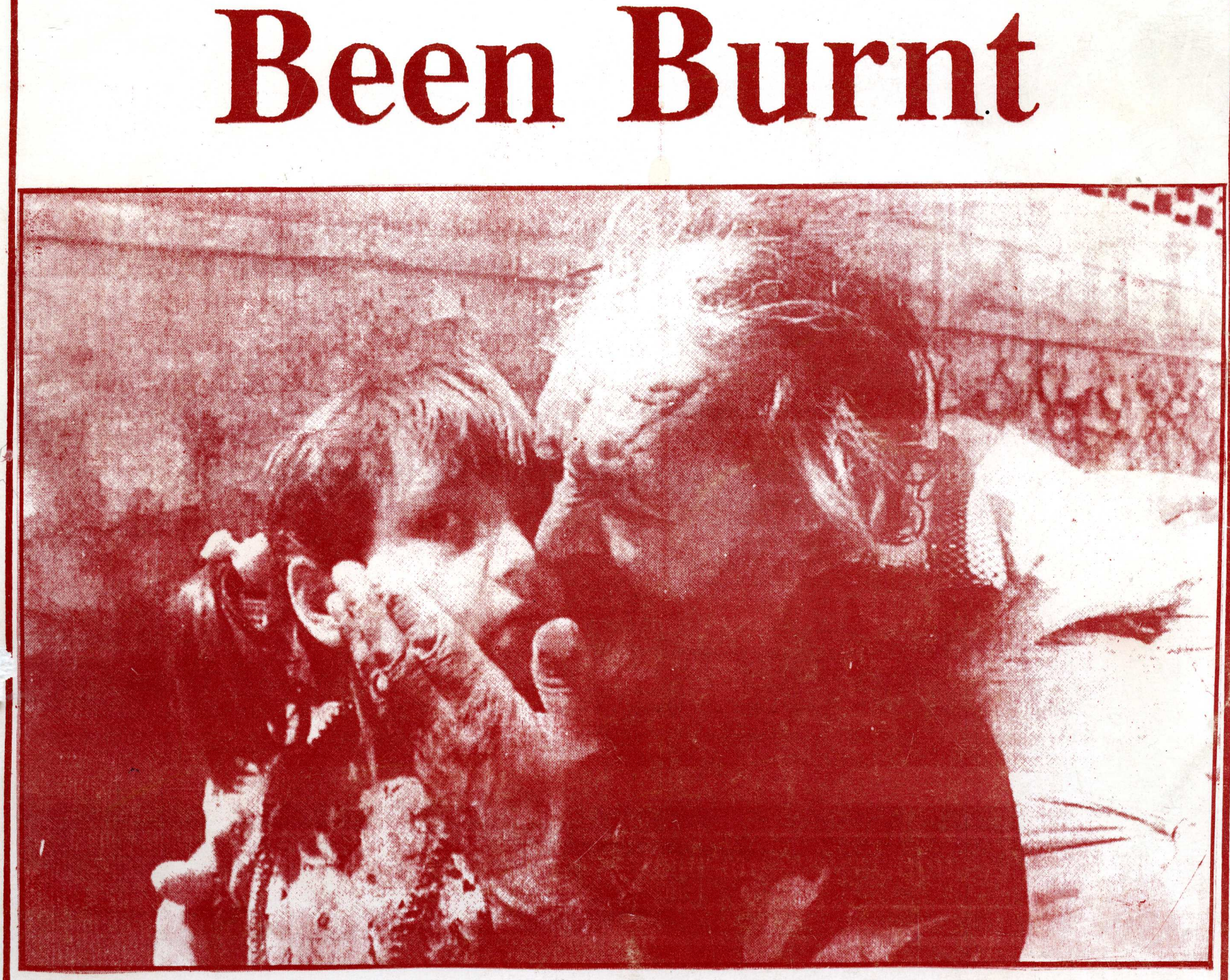


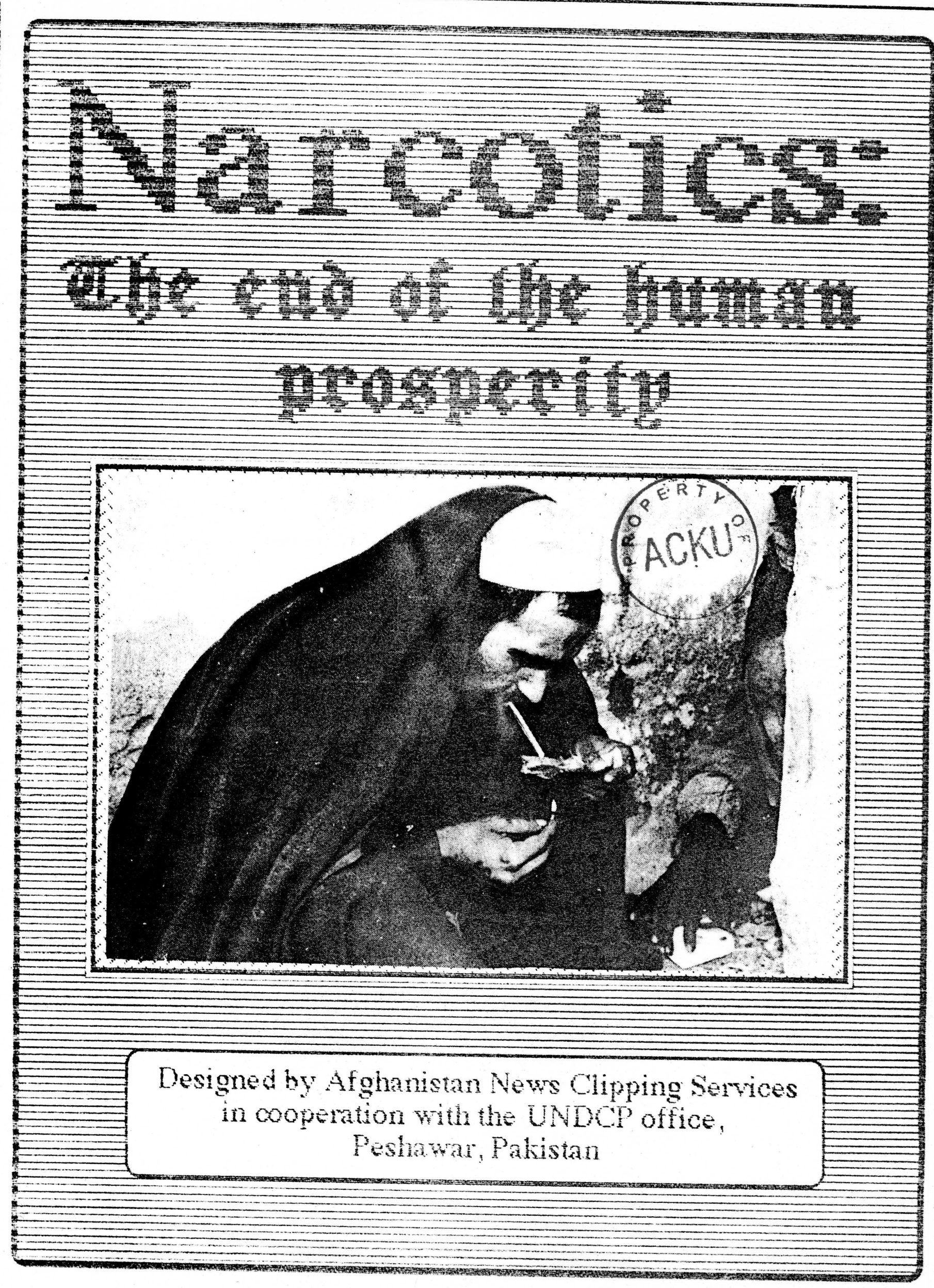




\section{Afghanistan News Clipping}

No. 46, April 1994

* AFGHANISTAN:

Political Aspects........1 Mestiri's Peace Mission..16 Peace efforts.........38 Zahir Shah...........43 Mines...............46 Poppy Cultivation.......47 Islamic Scholars' PeaceMission..............49 Arab Nationals.........59 Comments...........660 General............56

* KaBUl/AFGHAN GOVT.

Political Affairs......75 Domestic Affairs.......883 Factional Fighting......88 Ceasefire Efforts......100 Najibullah(Fmr. Prdnt.).103 Pakistanis in Jail.....104

* LEADERS/PARTIES

Maulavi Nabi (HII).....105 Gilani (NIFA)........107 Yonus Khalis (HIA).....109 Mujaddedi (ANLF) .......110 Hekmatyar (HIA) ........112 Sayyaf (IIA) ..........115

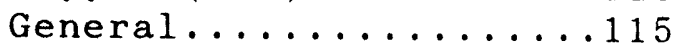
Sayed Jamaluddin......118

\section{* $\quad$ REFUGEES}

Political Aspects......120 Social Aspects........124 Repatriation.........126 New Refugees..........127 Refugees in Pakistan...129 UN/WFP Mission........130 Pak. Govt. Policy......131
* ForEIGN INTEREST:

Pakistan............133

UN................143

Amnesty International...145

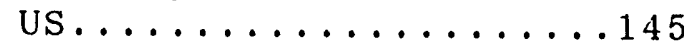

Britain............145

UN/OIC..................

Saudi Arabia...................

Iran...............149

Photos..............150

Cartoons................168

Blow Back from
the Afghan
Battlefield

..............Page 69

$* * * * * * * * * * * * * * * * * * * * * * * *$

Mahmood Mestiri's

Peace Mission

In Afghanistan

..............Page 16

$* * * * * * * * * * * * * * * * * * * * * * * * * * *$

\section{Afghanistan News Clipping}

Prepared by Afghanistan News Clipping Services (ANCS) Mailing Address: G.P.O.Box \# (383), Peshawar, Pakistan Publishing Staff: Fawad Ahmad Azizi and Taufiq Ahmad Azizi

Cover: An old man comforts his daughter who is frightened by the sound of exploding rockets in Kabul. _AFP Photo (File Photo) Cover Design by Fawad Ahmad

Price: Pakistan Rs.400- US\$20- (Abroad: US\$30-) 
When former president Najeebulquish his post, his party divided into two factions. One was led by Gen. Rashid Dostum while the other, mainly the Pukhtoon political stalwarts and officers of the armed forces, bureaucracy, joined Gulbadin Hikmatyar's Hizbe Islami. Dostum announced a coup in the nonhern Afghanistan and was joined by another former president, Babrak Karmal.

The top ranking leaders of PDPA (the then ruling party) thought what would be their position in a situation when Najeebullah had resigned and there was no clear ruler of Kabul. They did not want to become prey to a mujahideen group or alliance ruling the country or its capital. This consiteration-led to a Freatyol the North:-A number of generals joined Dostum and Karmal. While Najeeb's defence minister, Aslam Watanjar. joined Hikmatyar. The components of the North Treaty concentrated their forces in Mazar-i-Sharif and those of Najeebullah's former confidants who joined the camp included Gen. Momin, Gen. Baba Jan. and Gen. Jafar Naderi.

Najeebullah, as is now known to all and sundry, wanted to resign because he wanted to leave the country without any bloodshed. $\mathrm{He}$ wanted transfer of power in a sinooth manner. But the warlords of the mujahideen groups started aining Kabul with all kind of exploes to grab the capital exclusively. mly during the last month's suzkashi over Kabul, which began on the New Year's day, has resulted in the murder of at least 15,000 unarmed inhabitants of the Afghan capital and its suburbs. More than 80 per cent buildings have been completely destroyed in Kabul and there is no end to the murder-incold-blood in sight.

Immediately after Najeebullah was deposed the Karmal-Dostum forces captured all the northern provinces of Afghanistan. these included Mazar-i-Sharif, Taaluqqan, Bahlan, Kunduz, Jozjan, Faryab, Samangan, Badghes and Parwan.

Ahmad Shah Masud, the commander-in-chief of president Burhanuddin Rabbani's armed forces, started moving from his rieadquarters in Panjsher, about 100 kilometres from Kabul, towards the capital, and captured the province of Parwan, and the Bagram airport - near Kabul. Masud was supported by a portion of Najeeb's forces and also of Rashid Dostum's air-force.

Under the Peshawar Accord reached among the mujahideen forces immediately after Najeeb's ouster, Sibghatullah Mujaddadi was assigned presidentship for an interim two month period. Hikmatyar's party was allotted the post of the prime minister while Ahmad Shah Masud was designated as defence minister of Afghanistan.

On joining of the Pukhtoon generals like Aslam Watanjar, Manuke Mangal and Gen. Rafi, the general impression was that Hikmatyar was rallying the Pukhtoon element of the PDPA. Because the non-Pukhtoon PDPA generals and party leaders had joined Rashid Dostum. But the fact remains to be highlighted that when Dostum started mobilising his torees against Najeethtilatis the de posed president sent signals to Hikmatyar for joining forces. The result was that Najeebullah's Pukhtoon comrades joined Hikmatyar. A whole Fifth Division of the Khad joined Hizbe Islami of Hikmatyar.

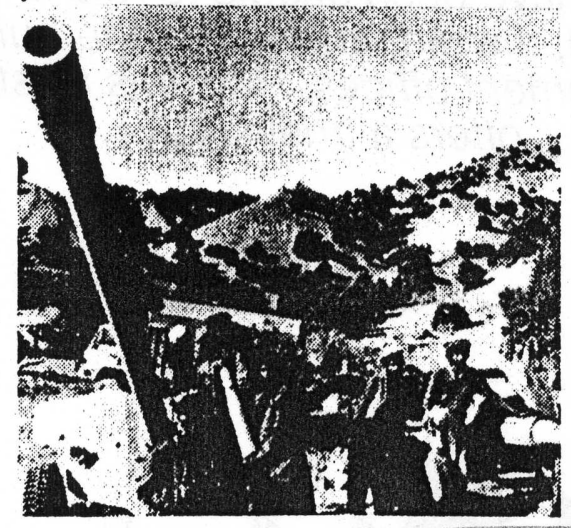

This triggered a proces; of division on the bases of Pukitoon and non-Pukhtoon and this wis started by the comrades of Najeeiullah for taking a cover after his ouster. Some of the Pukhtoon lenders of PDPA, however, joined Babrak

Karmal. They were Abdul Haq Uloomi and Noorul Haq Uloomi. They were the members of PDPA's Central Committee. Raz Moharnmad Pakteen, a Jabbar Militia general, joined Gulbadin Hikmatyar.

The army divided on the two sides so that the Northern Flank merged under the forces brought to Dostum by gen. Baba Jan, gen. Jafar Naderi and Gen. Momin's militias, with their headquarters in Mazar-i-Sharif. The integration was given the name: Junbash-i-Nazzar and it became to be known as Ellaf-i-Shumali(the Northern Pact): This alliance captured Kabul. Rabbani being the leader of Masud, started ruling as president with the assistance of Masud and Dostum forces. Hikmatyar sensec being left out.

\section{The Tussle}

When the Northern Pact captured Kabul, and Hikmatyar stationed himself in Caharsyab, instead of Kabul, the Peshawar Accord became irrelevant. Now the war for Kabul started and the positions were, for the first time, clearly taken against one another by the mu. jahideen factions. Opponents of the present bloodshed in Kabul are of the opinion that the Peshawar Accord was the first step towards this random murder of thousands, in Kabul and elsewbere in Afghanistan. Becatise as soon as the mujahideen groups arrived in Kabul, the tussle for capital started and the city started! eceiving rain of rockets and missiles. Hikmatyar demanded immediate ouster of president Mujaddadi. Ahmad Shah Masud started defending Kabul against Hikmatyar, as defence minister. President Ghulam Ishaq Khan wrote to Mujaddadi that he had a term of two months and should relinquish presidential slot at the end of the 60 stipulated days. The post was given

to Burhanuddin Rabbani, as envisaged in the Peshawar Accord.

But the change of president in Kabul did not prove any bit of a start of a process for peace making between Masud and Hikmatyar. Rather the change led to further bloodshed and Hikmatyar started pounding the capital with whatever he had in his arsenal. The PDPA forces that had joined Hikmatyar, were assisting him in his onslaught on Kabul.

It was an essential undertaking in the Peshawar Accord that during the four-month presidential term of Burhanuddin Rabbani, a Shoora Hal-o-Aqb (Council of Men of Wisdom) would be evolved which would determine the share in power for a ruling coalition of the mujahideen groups. That stage is yet to come. The war against Rabbani by Hikmatyar continued during which Rabbani rallied the support of commanders from far and wide of Afghanistan. Thus he assumed the position of a permanent president. This resulted in furthering the bloodshed. The Afghan leaders were called to Islamabad Accord and then, the Makka Accort. 


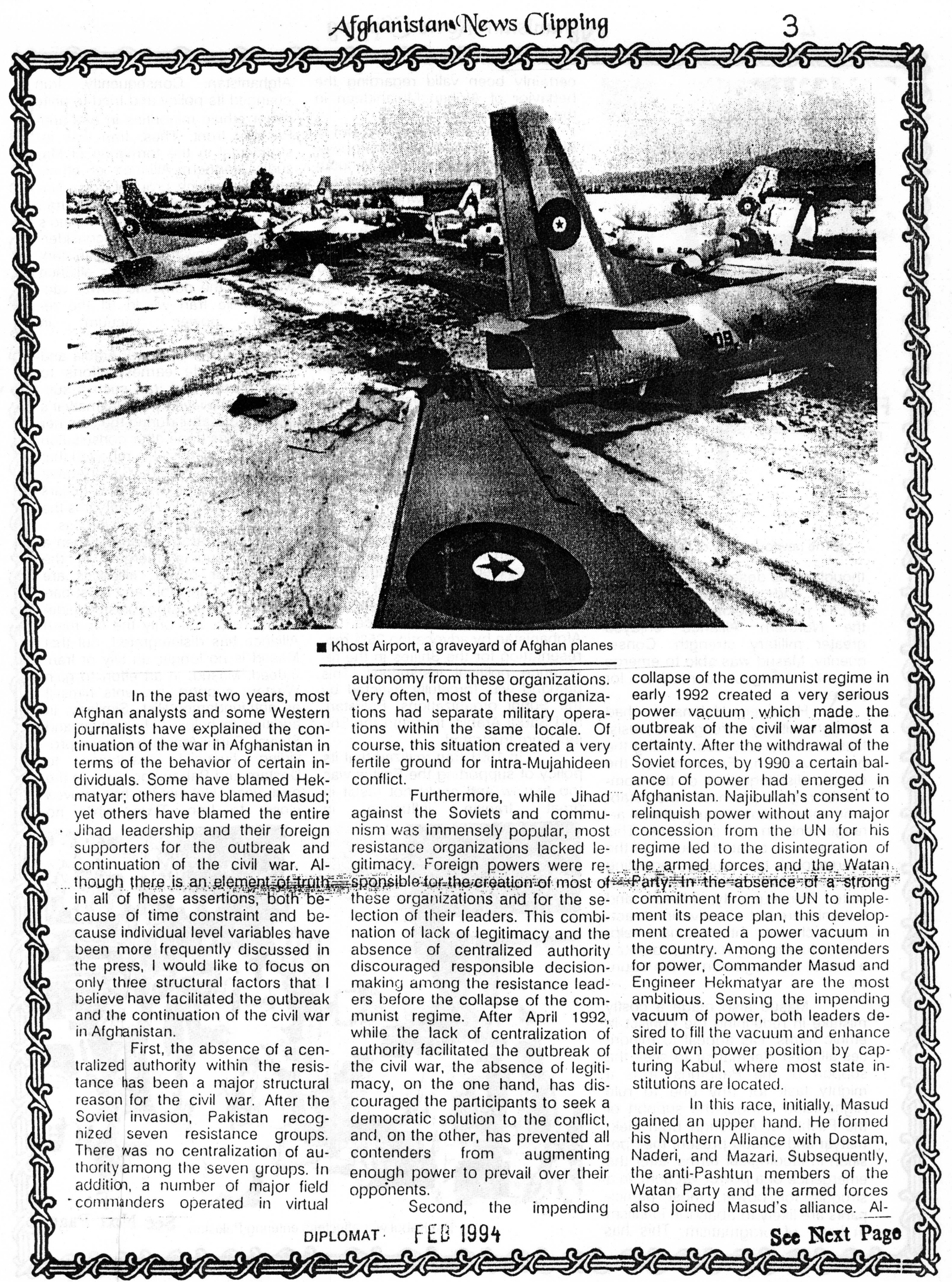




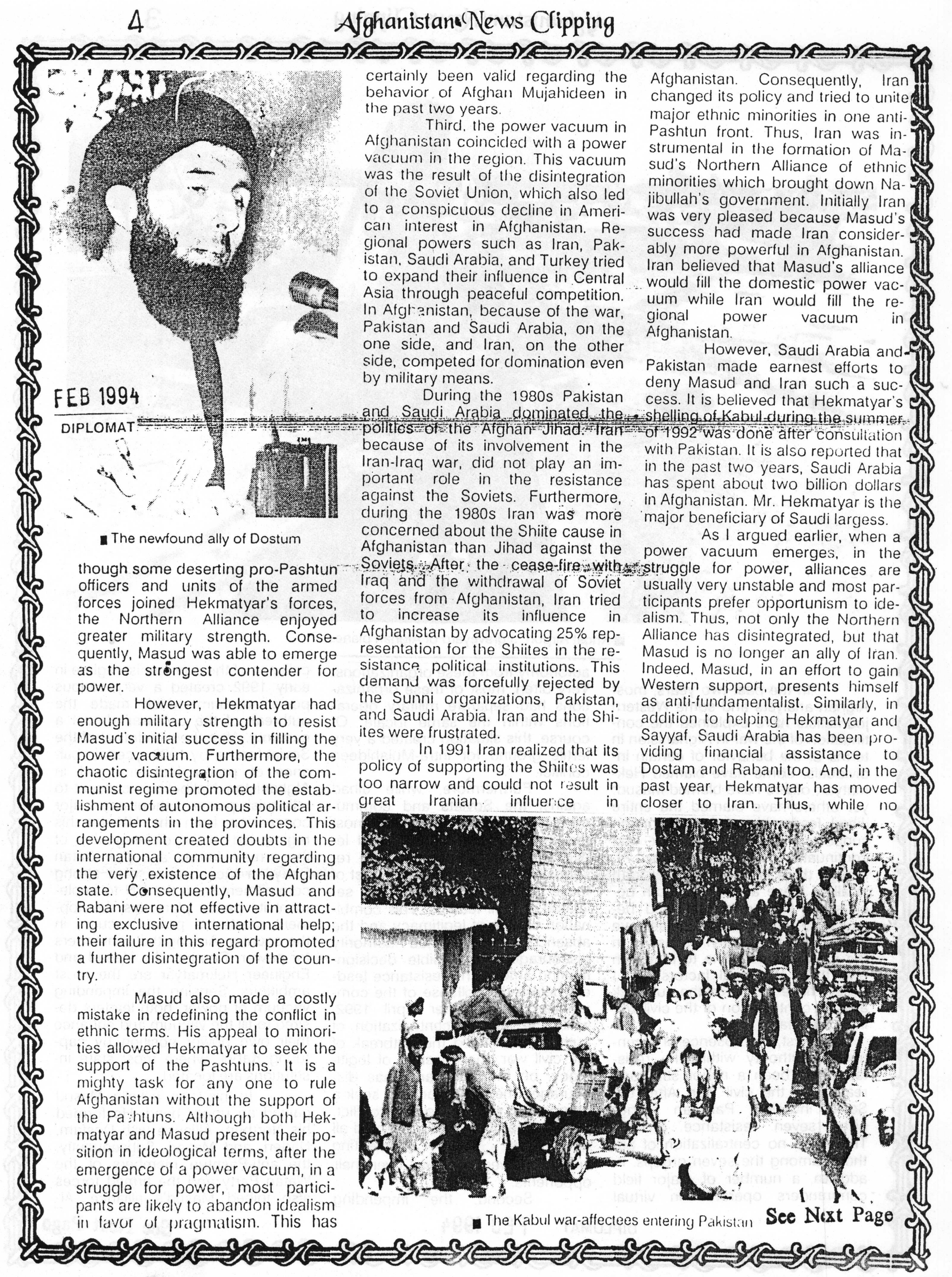




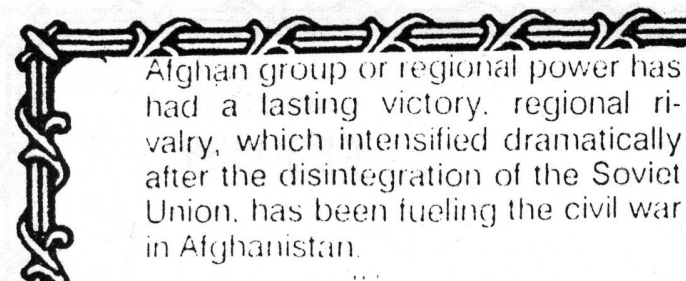

\section{What Can Be Done?}

Can the international community help to resolve the Afghan conflict? I believe that the Afghan conflict is ripe for resolution. Afghan groups who intended to clominate Alghan politics have failed in their efforts: they realize this failure. Regional powers also realize their failure to dominate Afghanistan. The current political and military stalemate is likely to increase the willingness of the participants to reach a compromise. However, without international intervention in favour of peace, I do not think that the Afghans by themselves can estab-

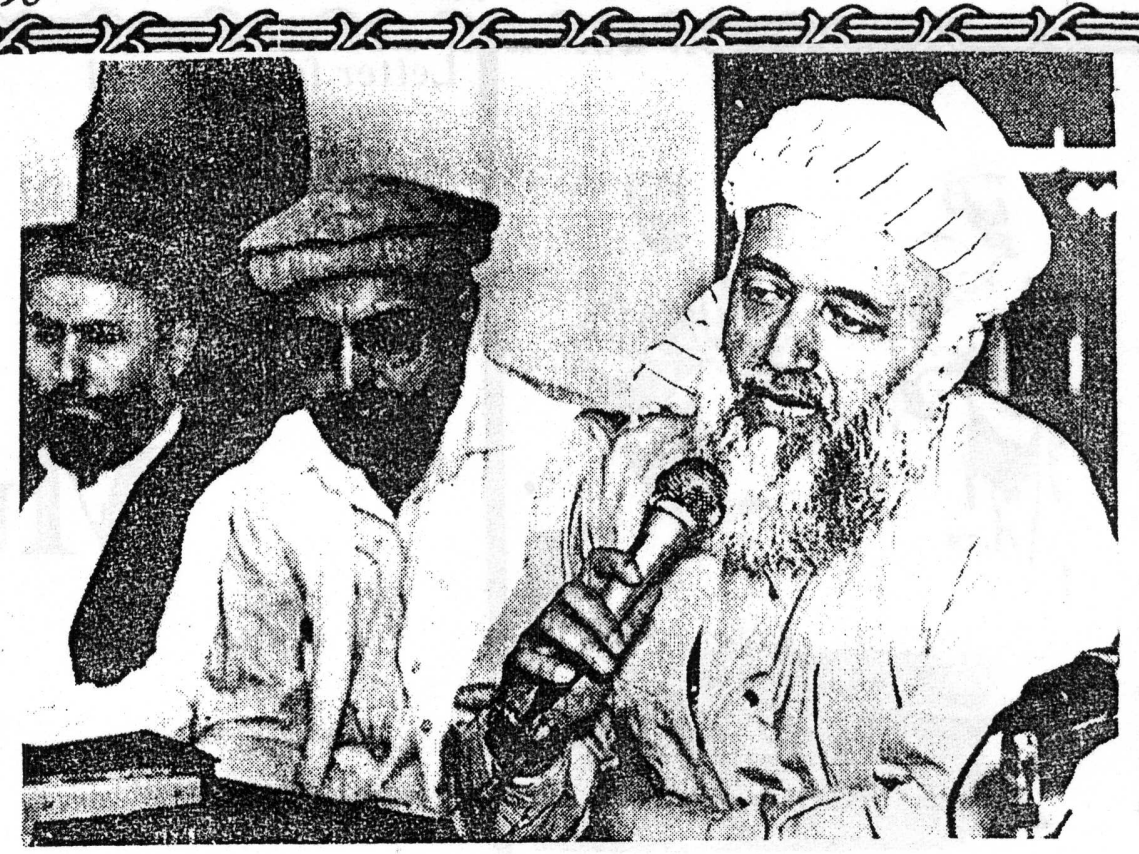

Future uncertain lish peace in the country. Without international intervention and foreign assistance to the warlords, the current stalemate is likely to lead to a deface to disintegration of the country.

The United Nations should resume its peace-making mission in Afghanistan. In order to be successful, the UN must have the support of the United States, Russia, Saudi Arabia, Iran, and Pakistan. Although in the past, the regional powers did not want the UN to succeed in Afghanistan, I believe that now they are likely to welcome a resumption of the UN peace-making mission.

two major objective. First, the state has broken-down; the UN must help) to reconstitute the Afghan state. Historically, state-building in Afghanistan has always required foreign assistance; this time international assistance is even more crucial. Second, in the long run, the state and the regime has to be legitimate. I believe that the Afghans are able to negotiate their differences regarding substantive legitimacy. Such negotiated agreements should be reflected in the constitution. However, I do not believc that without general elections genuine procedural legitimacy can be achieved. Unfortunately, genuine elections are impossible without se-

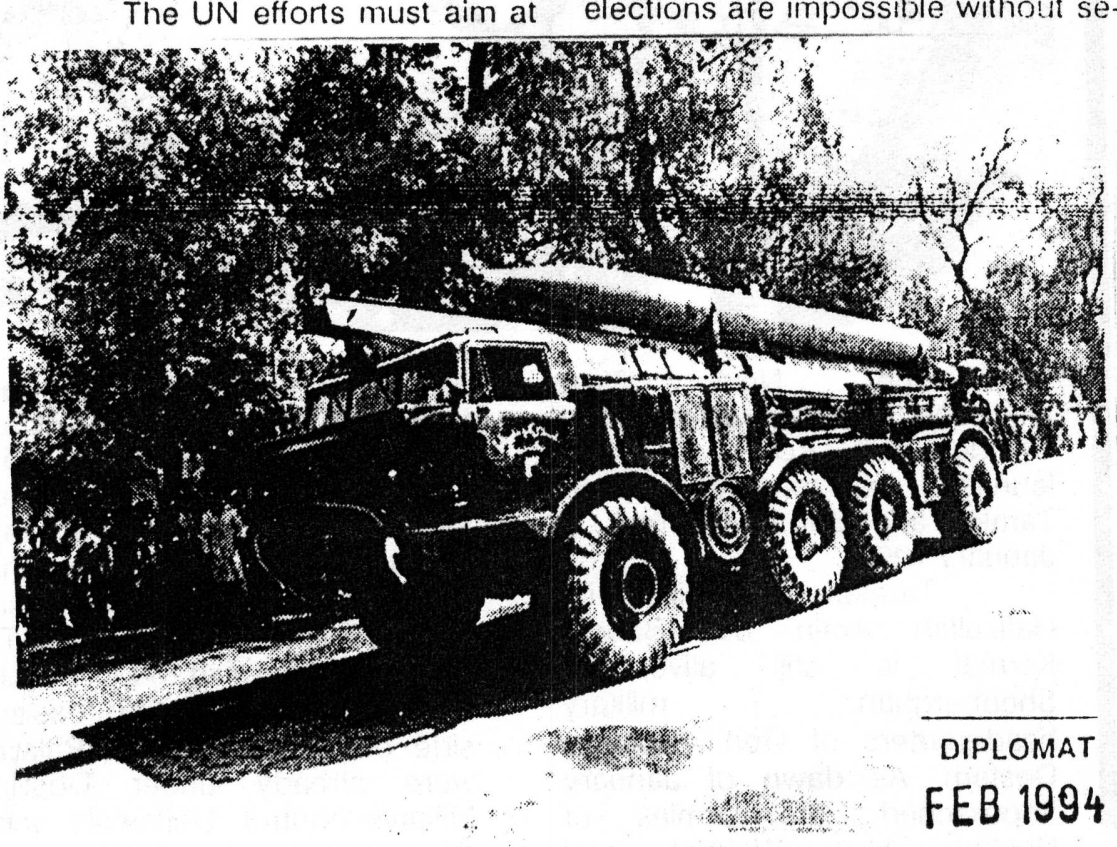

curity. Thus, the UN should first foeus on reconstituting the Afghan state: In this regard the elimination of the private armies and the establishment of a non-partisan national security and defence forces are absolutely necessary.

The issue of who should preside over the rebuilding of the state institutions is very controversial. I can think of three alternatives. First, following the Cambodian model, the UN can assume large responsibility for rebuilding state institutions. Although, given the distrust among Afghan groups, in my opinion, this is the most desirable alternative, given the scarcity of UN resources, I do not think this is a realistic alternative. Second, a group of non-partisan Afghan technocrats, in a transitional government, can be entrusted with the responsibility of refonstitutiug the state Howeyer these individuals should not seek public office immediately after the transitional period. I think this is both a realistic and desirable alternative. And third, although the resistance organizations that have formed the existing so-called govermment are very much distrusted by the people, if they insist on forming the transitional government, they can assume responsibility for rebuilding the state institutions provided that they involve the UN in w hese sforts. Otherwise, distrust of among themselves is likely to leadfr to another round of violence. Furthermore. without the UN involvement, they are not likely to establish $\mathbf{4}$ a state and a regime that would 


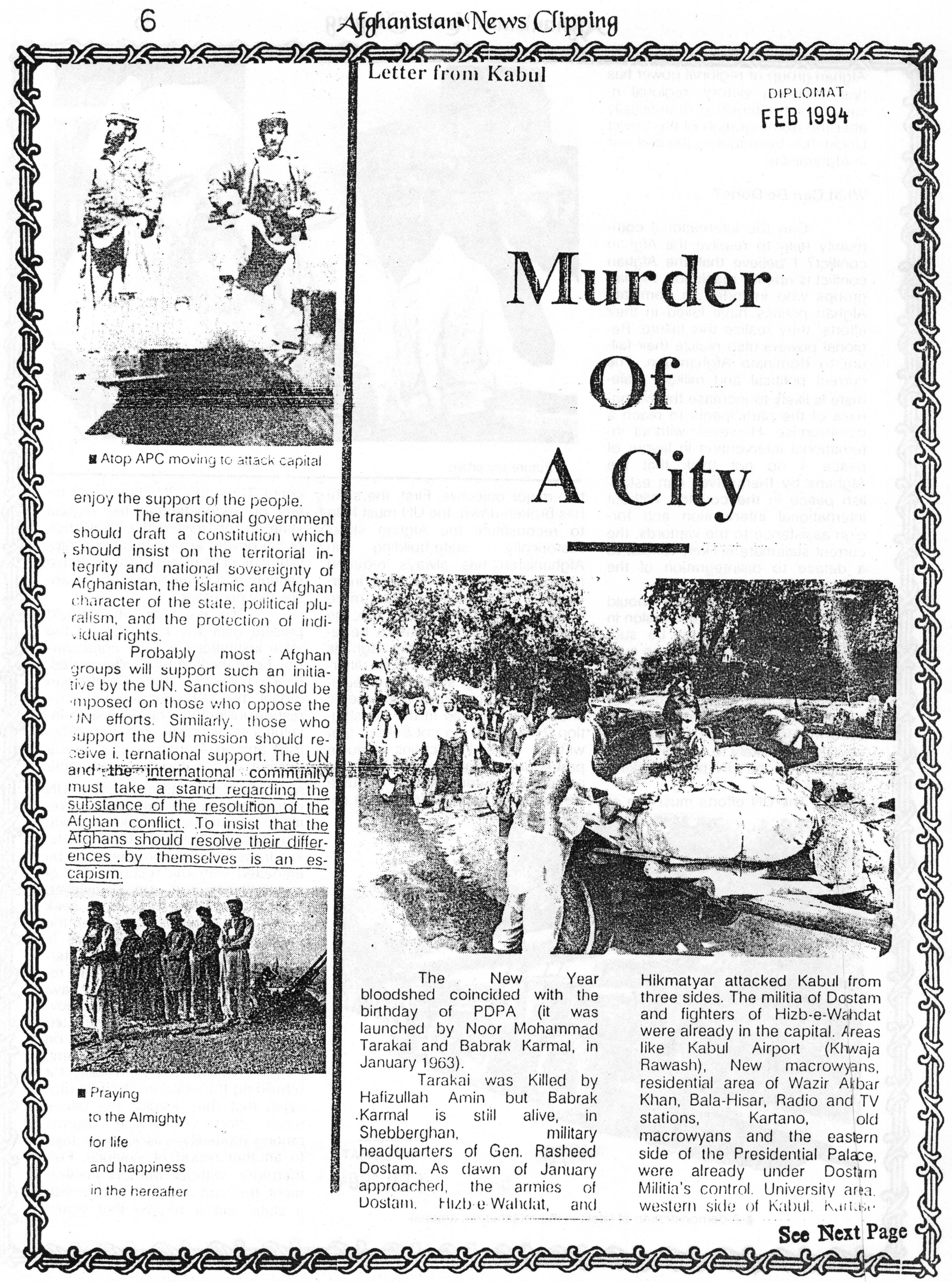




\section{Afghanistan "News Clipping}

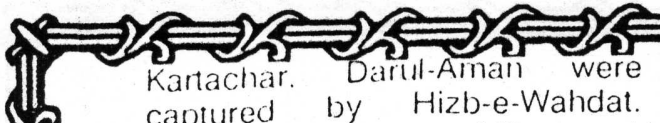

captured by Hizb-e-Wahdat Hizb-e-Islami (Hikmatyar) captured the eastern and southern suberban areas of Kabul city. The armies of Hikmatyar. Dostum and Hizb-eWahdat altacked the city from eastern, southern and western sicies, respectively. The attack was so severe that vithin two hours the combined armies captured the ministry of defence and other official buildings. But later the armies of Ahmed Shah Masood encountered the attack and retook these areas. Thousands of innocent citizens died during early hours as residential and official buildings were perished. Approximately 7000 rockets hit Kabul during the first attack. Many people including children, the old and women were injured. No one was there to rush them to hospitals. Hundreds were buried alive-under the debris.

Heavy snow fall and zero temperature, no electricity and water supply in the city has made life practically impossible. The city is still under shelling and rocket attack. Dust and the clouds of smoke have engulfed the whole town. During air attacks by Dostum forces, most men died for lack of first aid. people who were living in Soviet made flats, were forced to leave their houses and take shelter underground. Reports from there are that they are suffering lack of food and worm clothes. Because of shorlage of food and electricity many children and old Kabulites died and are dying every day. Dostum's fighter planes contloue anto annihilate the civilian population. The historic pule khishti mosque of Kabul has completely demolished. In this mosque Pakistan's dictator, Gen. Zia wished to offer prayers of thanks on "Fatha Kabul". Business areas like Srai Shahzada which is the centre of currency exchange has also been destroyed.

Aftur one week's heavy fighting the official armies recaptured, the entire eastern, southern and western areas of River Kabul, including Kabul the air port, whch was captured by Dostum's malitia in the first

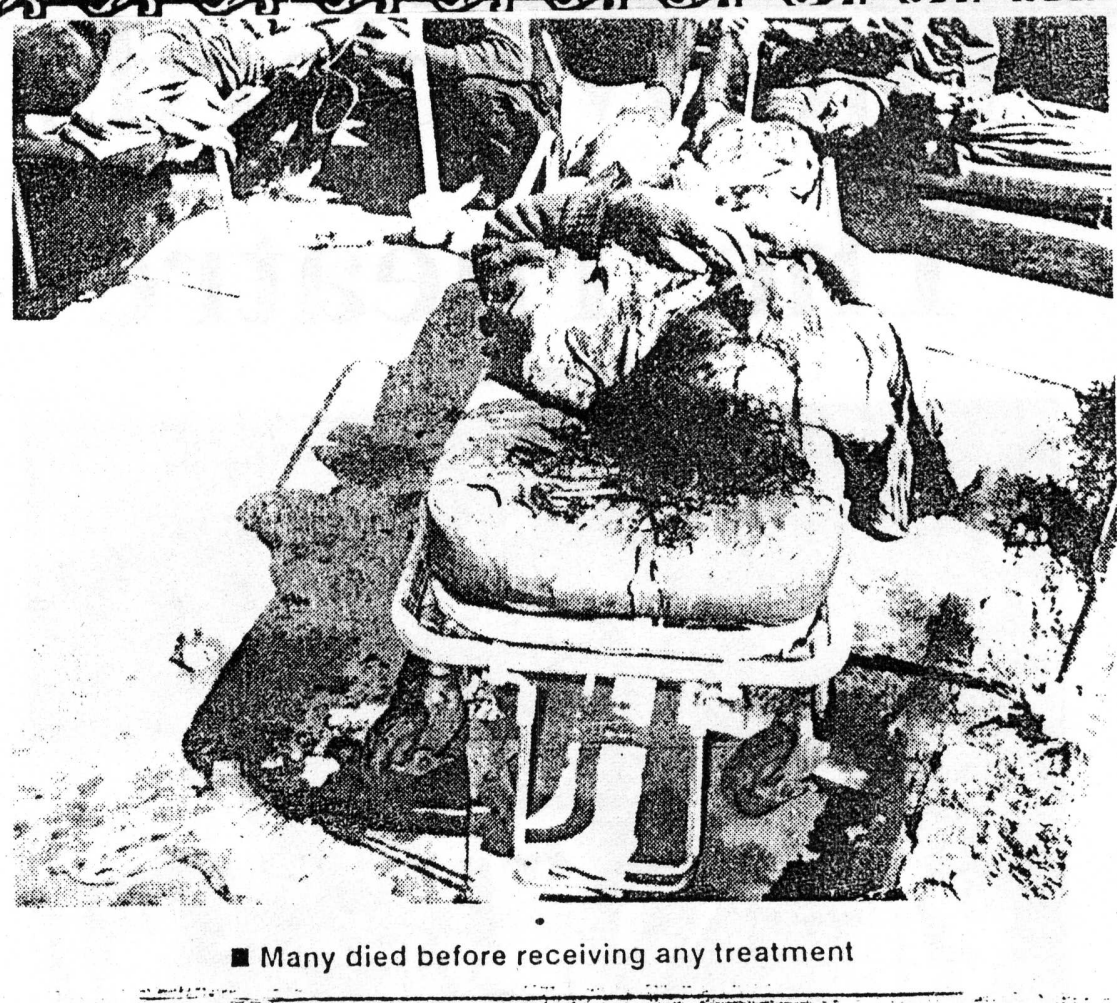

attack. But in this process of capturing and recapturing the building of the airport was razed to ground. The runway was almost completely destroyed and rendered inoperative.

The bloodiest clashes took place on Bibi Mehro Mountain and in its surroundings. This mountain was first under Dostum malitia's control from where he attacked the charasyab area, location of Hikmatyar's headquarters. It is considered to be the strongest post of Dostum's militia storing heavy ammunitions. But after Dostum and Hikmatyar joined har is; the same post was $\mathrm{u}^{\prime} \mathrm{d}$ for attacking the President \& Palace, Wazik Akbackhan lacrowyan and the airport. Heav / shelling was made on Kabul from this mountain. But now this mountain is under control of the official forces which recaptured following a ierce and bloody battle. Heavy loss of men was reported from both sides. Fighting here was stopped only for one day on the appeal of Pakistan, United Nations and other countries. People of Kábul had brief respite during which they fled the Afghan capital and its suburbs through the northern and eastern outlets. No transport was available to these citizens running for life.
Many ran barefoot in chilling cold down the stone-strew pathways. Thousands of men, women and children were moving along the road sides with barely sufficient clothes on to brave the freezing winter, on roads covered with kneeof the dislocated Kabulites reached Pule Charkhi but there was no food, no shelter to greet them. Pule Charkhi was also covered with. snow. The staff of Pakistani, Lybian, Indian, Indonesian, South Korean, Saudi Arabian, Iranian, Egyptian and French embassies left the city during the 24-hour ceasefire they had the transport facility available, का residents of old macrowyan under Dostum Militia's control had to face untold miseries. Dostum's malitiamen did not allow them to flee the city. Afghan women, who were moving towards North and East, had no proper clothes and ran without their traditional $b$ zils on. They talked among themselves that the Mujahedden after capturing Kabul issued orders that no women should leave home without the veil on. But now women were forced to leave their homes, without Hijab.

Seo Next Page -Waheedullah deep snow By evening scores 


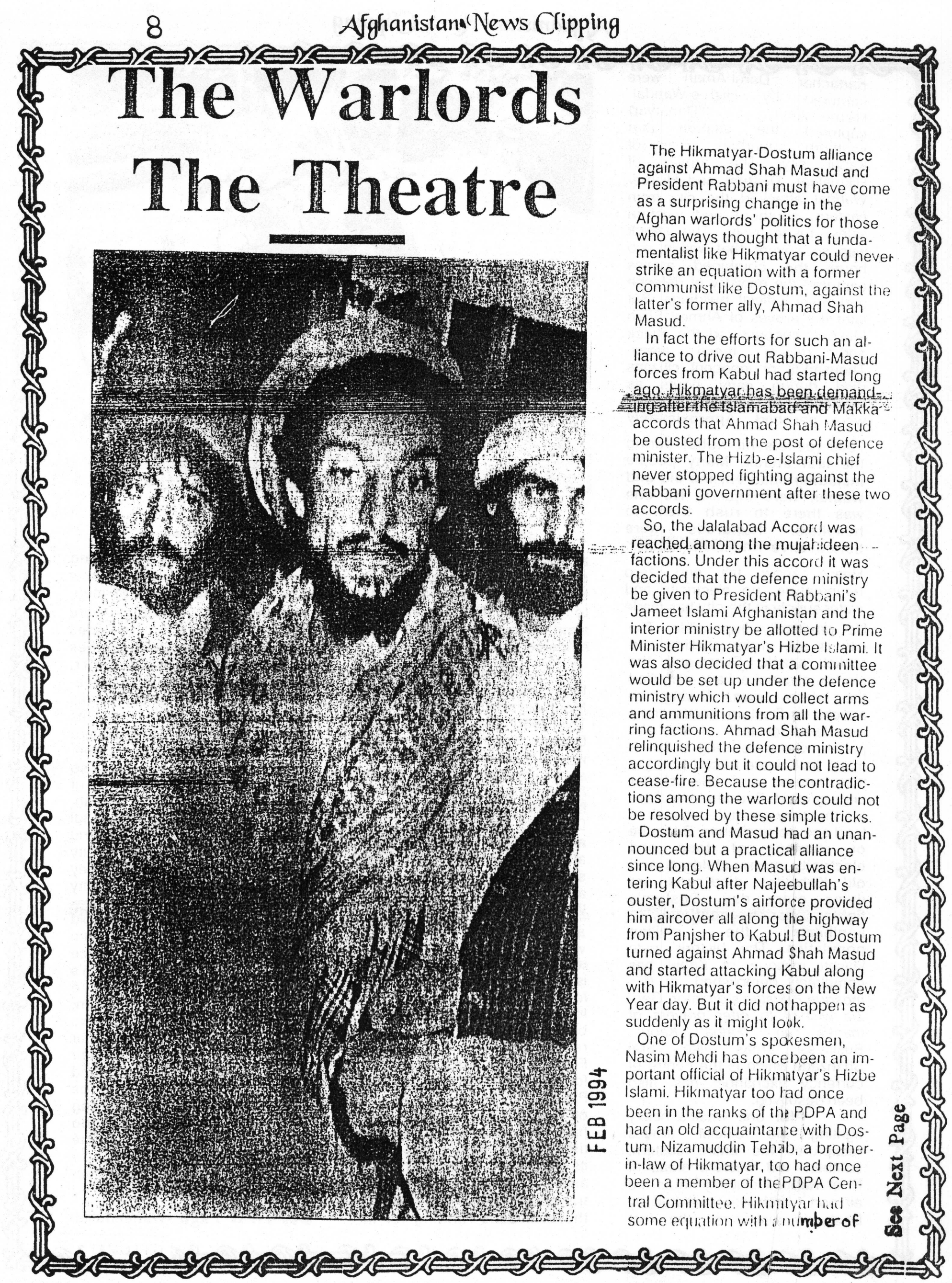




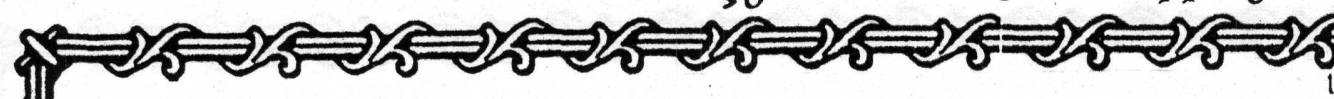

turit's connrades knew that Mastid

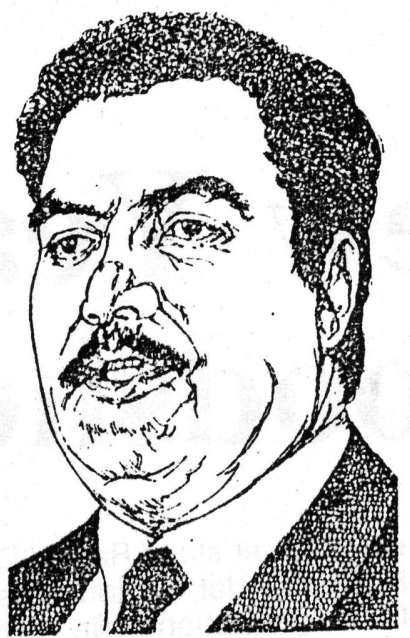

Najibullah.

PDPA officials though he was an unacceptable figure in the party, to the majority of party officials.

About a year ago, three gentlemen travelled in a vehicle secretly, from Kabul to Dostum's office in Baghlan province. They were

ard those feelings

comcerned over the

new situation. Some

of the formeriy ames-

Rabbani hardirners

like Moulavi

Mohammad Naki, Qari Baba, Yovirus Khalis, commander's

of the Hilmand province, Rasoor Akhunzada, asid the

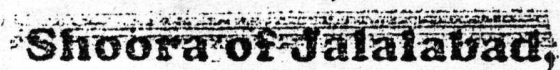
are now supporting him.

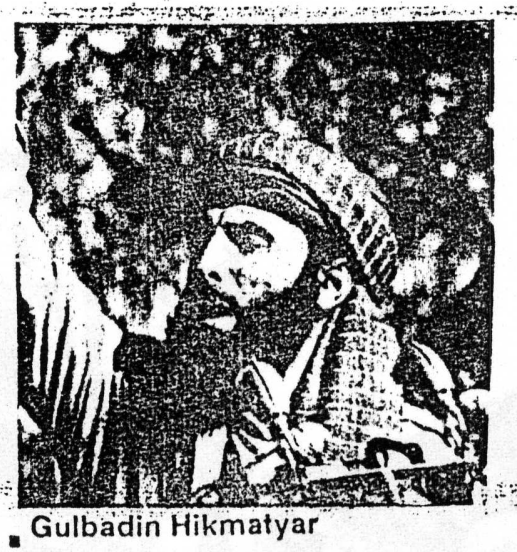

Ghairat Baheer (son-in-law of Hikmatyar), Engineer Waheeduilah (reportedly a commander of Hikmatyar's forces in Azarb, jan), and Engineer Kashmir (a cr:mmander of Hizb forces in the pro ince of Kuharr): They held talks ith Dostum on behalf of Hikmatyai These contacts later evolved into lose relations between the two, ior chalking out a united future strategy.

Ahmad Shah Masud knew about these contacts and struggled, all the while, to secure a rupture of the Northern Pact forces. He wished isolation of Gen. Baba Jan, Gen. Momin, and Gen. Jaffar Naderi from the Pact forces.

On his part', Dostum has been

demanding Junbash-i-Milli's share but practically Masud was holding power in Kabul and his failure to oblige him infuriated Dostum. Dos- was in the way of letting them have a share in Kabul government while Hikmatyar was already a discard, out of the capital. The anti-Masud sentiments on the part of the two warlords and their old contacts revitalised, pave the way for the alliance that tried to run Kabul over on New Year Day.

Can Hikmatyar-Dostum alliance last? is a question being asked by many now in Afghanistan and those feeling concerned over the new situation. Some of the formerly antiRabbani hardliners like Moulavi Mohammad Nabi, Qari Baba, Younus Khalis, commanders of the Hilmand province, Rasool

Akhunzada, and the Shoora of Jalalabad, are now supporting him.

In these circumstance, Dostum, as a force defeated in the first attack, can neither continue fighting a prolonged battle nor can his alliance with Hikmatyar prove a durable practice. Dostum's forces have been forced into a siege in Mazar-eSharif. He can no longtr receive. reinforcement and aid from Uzbekistan via Salanag Highway which has been blocked by Masud forces. There is no question of receiving reinforcement by air since the

Bagram and Kabul airports are under Masud's control.

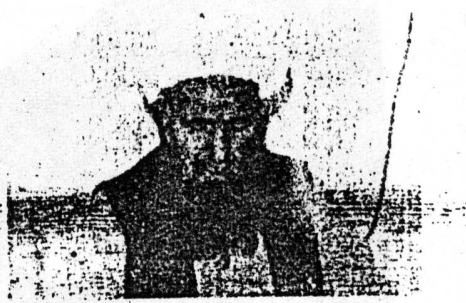

Younus Khalis

The government of Pakistan is in no position to continue support to Hikmatyar while on the other hand, the pro-Masud forces have mobbed upindifferentwareffected provinces and snatching Kabul from him by the alliance, without a prolonged battle, is an impossible proposition. Masud has also added to his political maneuverability and status by successfully repulsing the initial attack by Hikmatyar-Dostum alliance on the Afghan capital. Hikmatyar has lost considerably as a Pukhtoon leader by striking a patch up with an Uzbek leader who has recently been a staunch communist stalwart.

- Waheedullah

Seo Next Pago FEB 1994: 


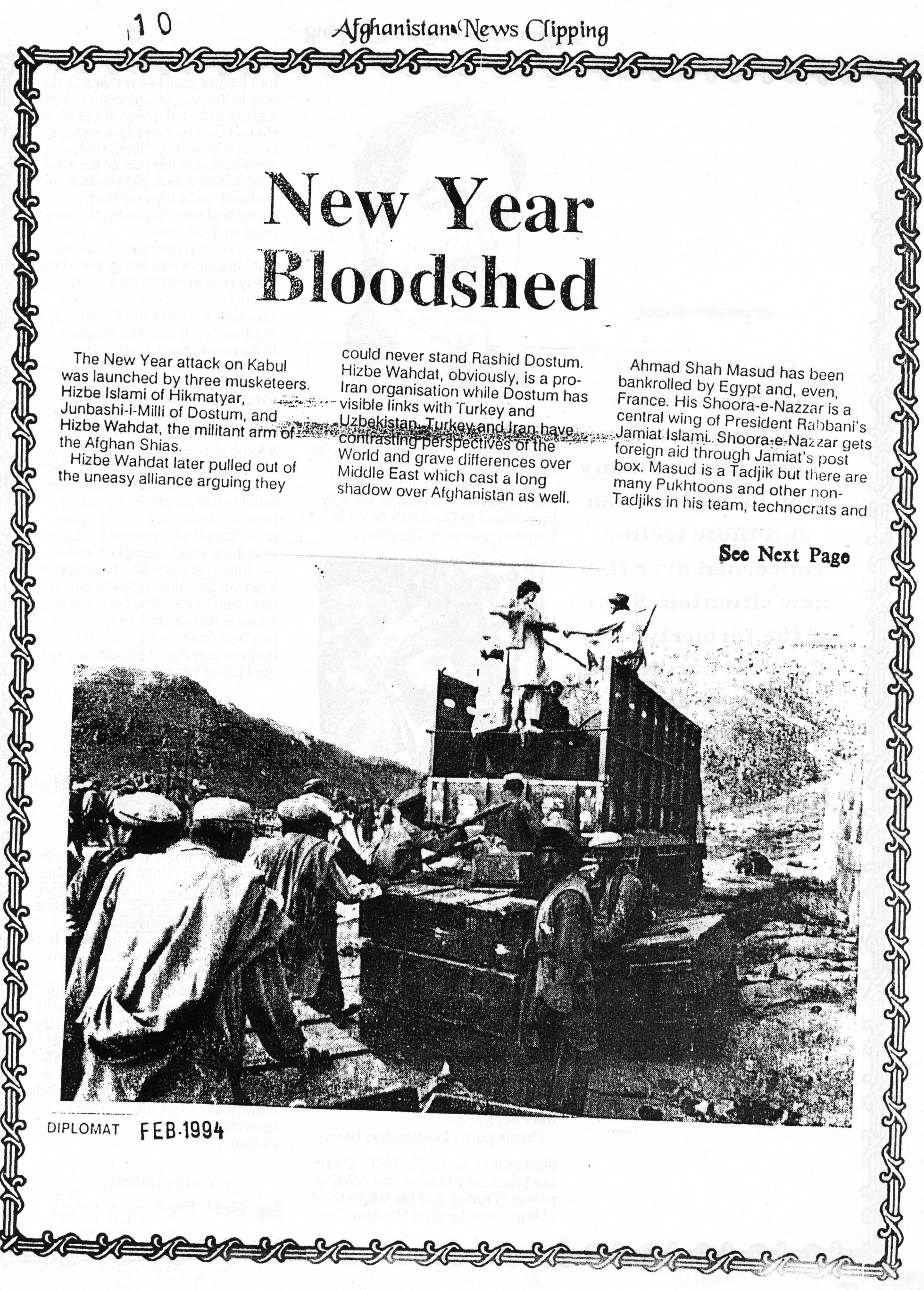




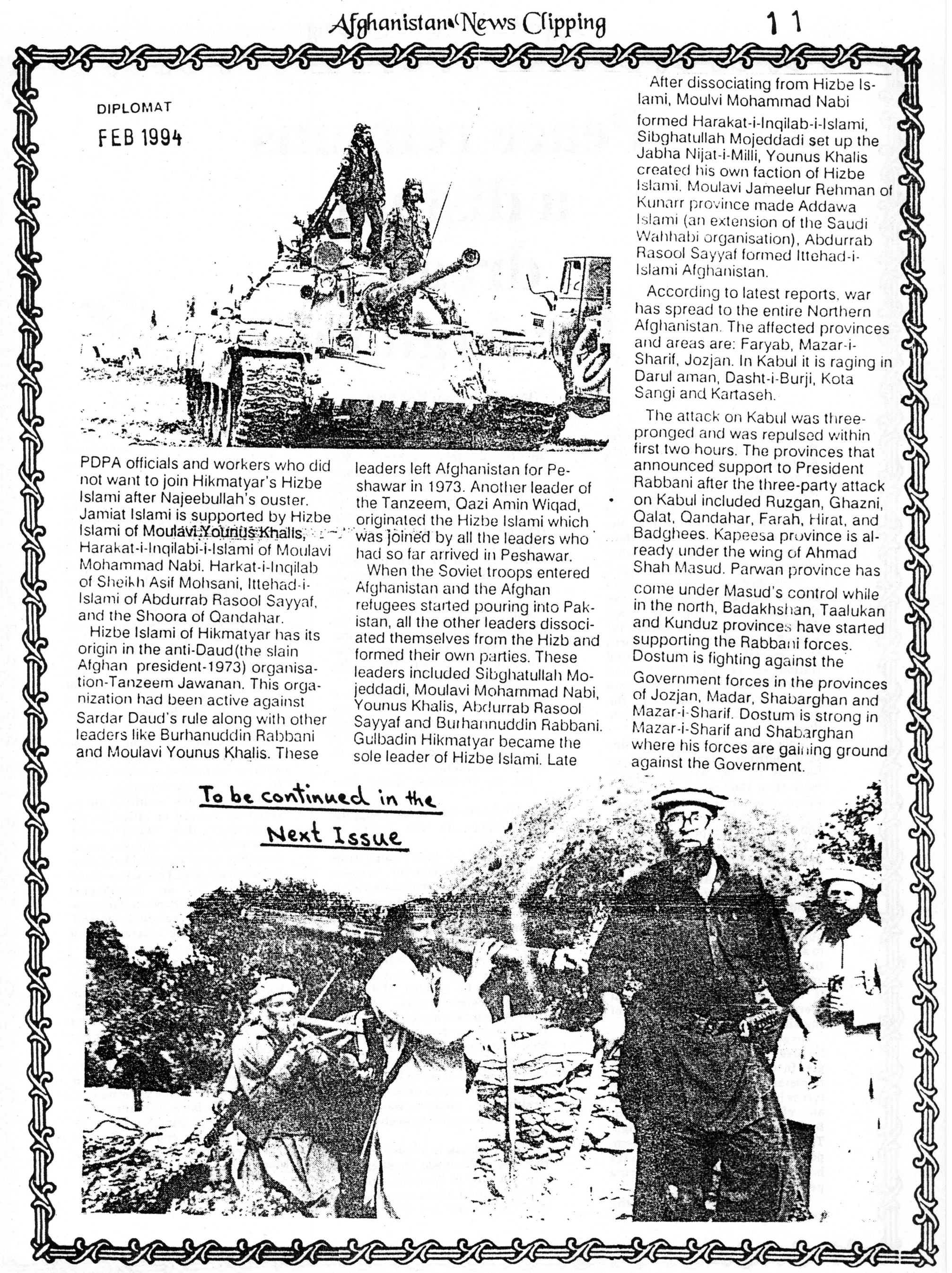




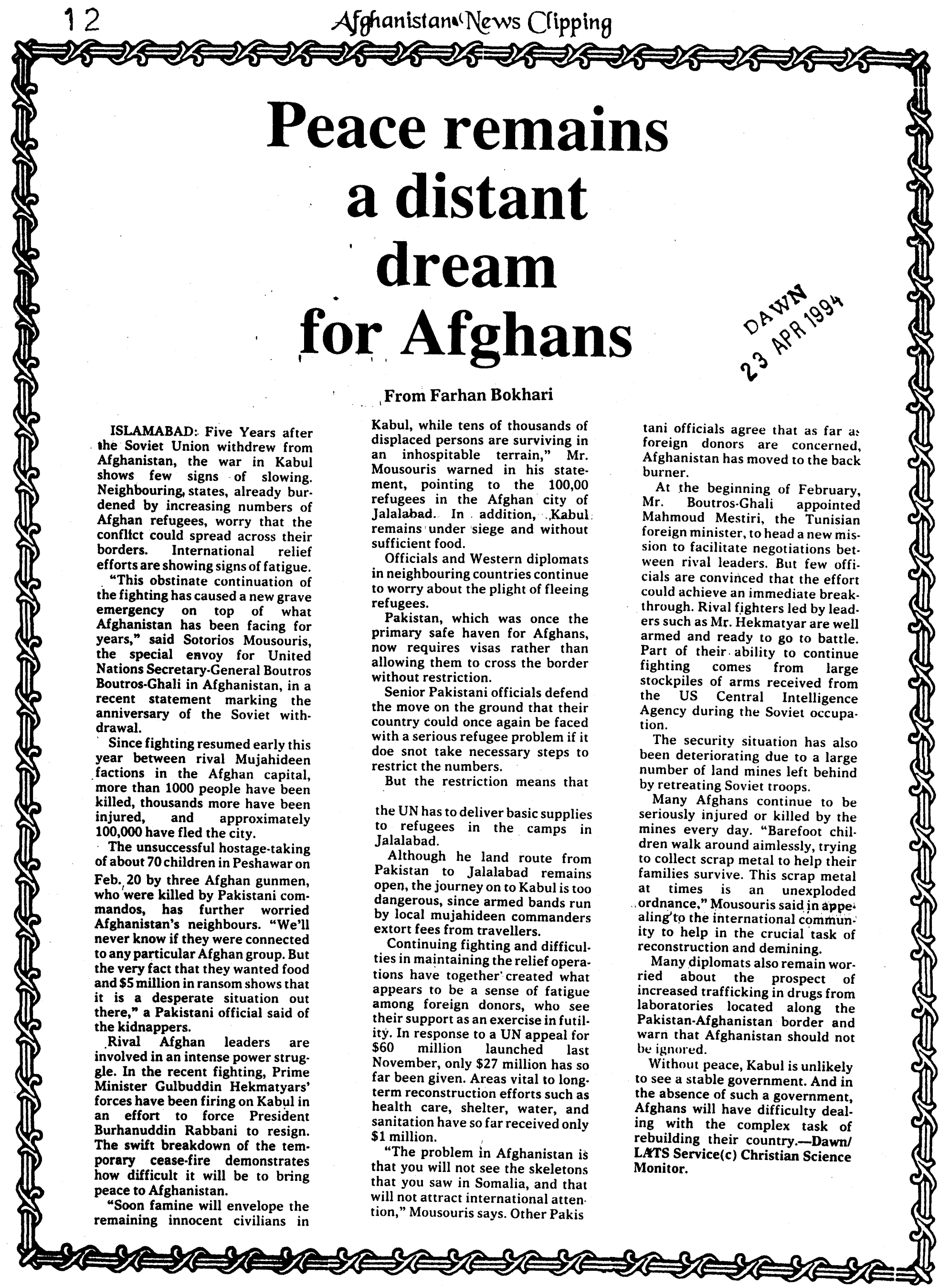




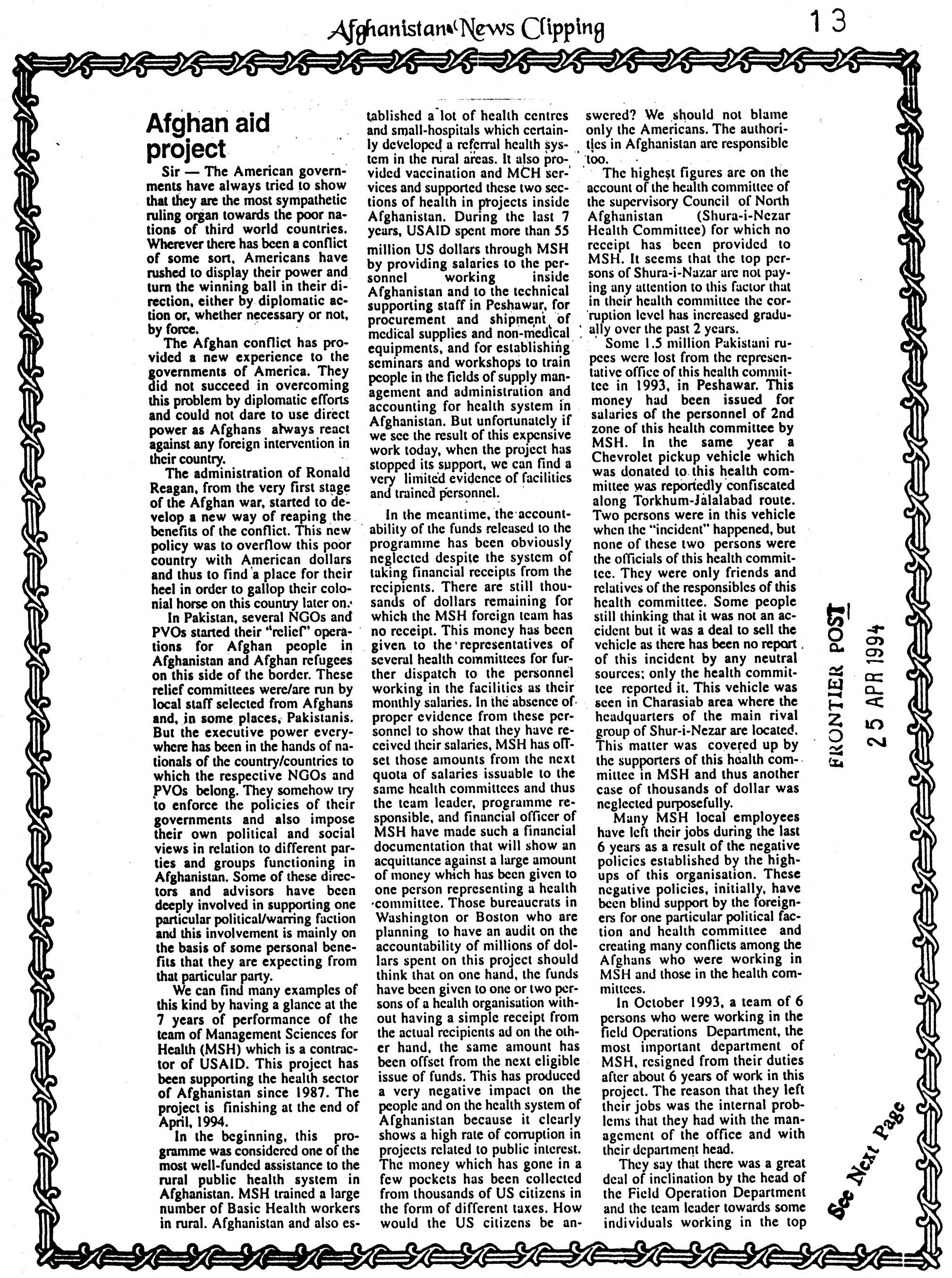




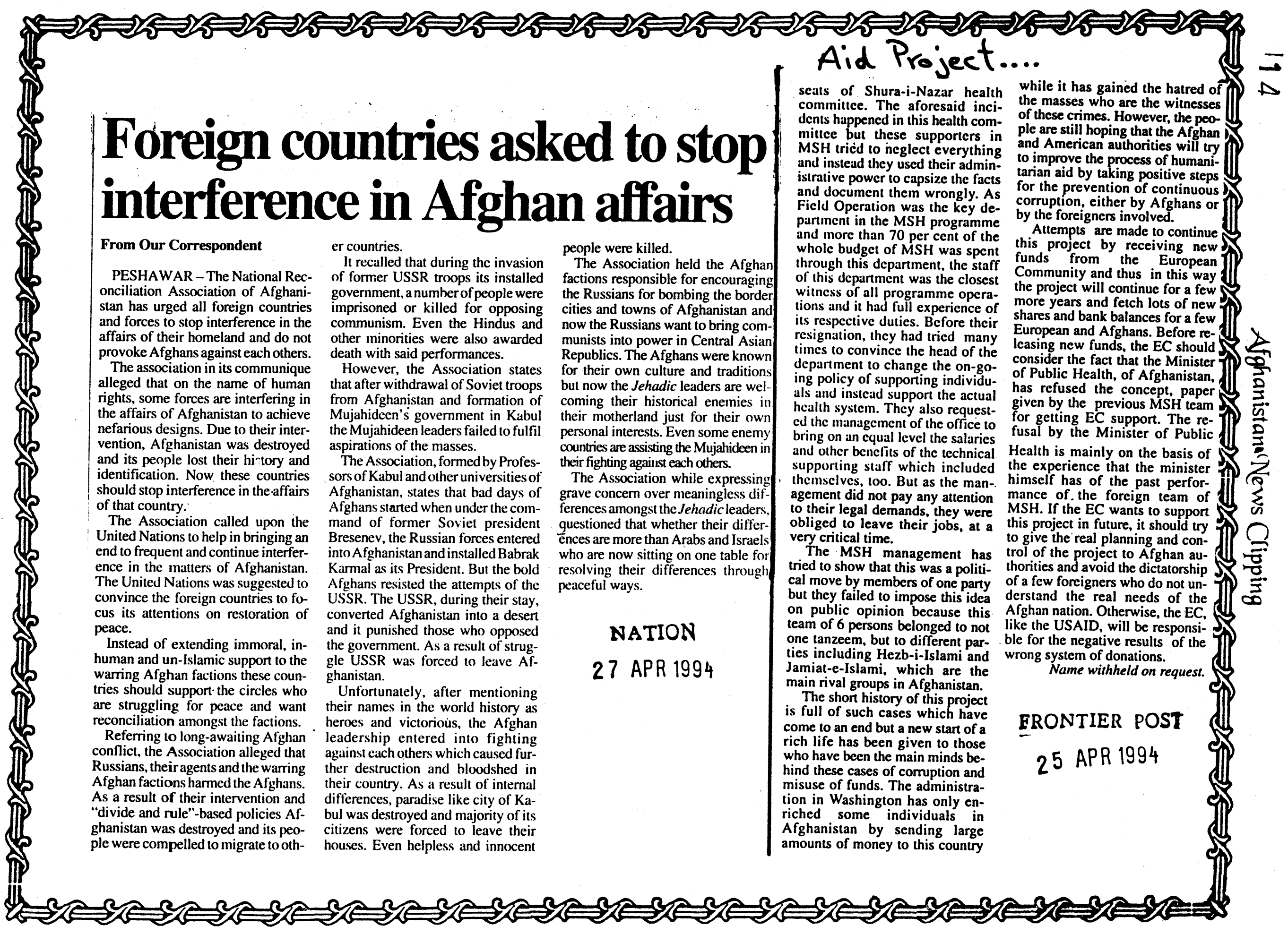




\section{Badakhshan on verge of famine due to unwise rulers}

\begin{abstract}
Bureau Report
PESHAWAR: Famine-like conditions have been reported from President Rabbani's native province Badakhshan - in northeastern Afghanistan due to a host of factors.

Across the snow-bound mountainous border, Badakhshan remains cut-off for seven months every year from Pakistan's Chitral province. But the ongoing civil war in Tajikistan which also borders Badakhshan, the closure of trade routes to Mazar-i-Sharif and Kunduz following the parting of ways between the Rabbani government and Gen Rasheed Dostum and stoppage of supplies from Kabul have all contributed to the food shortages and unprecedented price hike in the
\end{abstract} province.

Reports from Badakhshan said the Rabbani government has failed to respond to the plight of the people of Badakhshan.

On the other hand, former defence minister Ahmad Shah Masood sent helicopters to Badakhshan in January 1994 to collect young men through Jamiat-i-Islami commanders, Syed Najmuddin and Baseer
Khalid, and fly them to the frontlines against Dostum and Gulbaddin Hekmatyar. Najmuddin himself too 2,000 men to fight against the Is maili militia of Syed Jafer Naderi in Baghlan province. Such a policy has, however, driven hundreds of people to flee Badakhshan to Chitral to avoid conscription.

People arriving here from Badakhshan said a four-fold increase compared to the last year has been recorded in the prices of commodities of daily use. Kerosene oil is no longer available while one kilogram of vegetable ghee is sold or 70,000 Afghanis, one kilo of tea for 30,000 Afghanis, one seer (7 kilos) of wheat for 10,000 Afghanis, one seer of rice for 12,000 Afghanis and one kilo of sugar for 6,000 Afghanis. These prices are well beyond the reach of the common Afghans.

People in power, notably the commanders, live in luxury. Syed Najmuddin is alleged to have accumulated wealth through his control of Lapizlazuli mines for the past 15 years. He has reportedly earned millions of dollars and bought houses and opened bank accounts abroad. He also built houses and hotels in Baharak and a housing complex at Jurm in Badakhshan. His brother-in-law, Baba, and one Zalmai who run these projects com pel people to work for them without pelpes.

Syed Jan, a relative of Najmuddin, last year raped a girl. When she became pregnant, the people forced Syed Jan to marry her, but Jan divorced the girl two days later.

Badakhshan's capital, Faizabad, which is controlled by commander Baseer Khalid, often witnesses looting, rape and other crimes. All the shops and other property in Faizabad was looted when mujahideen took power.

Differences cropped up recently between Baseer Khalid who is a relative of President Rabbani, and his deputy, Abdul Haq, since both wanted to marry the same girl. The bone of contention was Nasreen, a former activist of PDPA. Four of Baseer's bodyguards were killed during a clash between his men and those of Abdul Haq. The local Mullahs issued a Fatwa that Nasreen should be killed as she was the

cause of dispute between the two mujahideen commanders. Howeve the people rejected the Fatwa and the matter remained unresolved. Meanwhile, the girl's family is perplexed whether to give Nasreen's hand to Baseer Khalid, who already has two wives, or Abdul Haq.

Wealthy people in Badakhshan are often ordered to surrender their belongings to mujahideen and in case of refusal, they are branded as Khalqis or members of the Sitam-iMilli. In Faizabad and Jurm alone, 50 rich people were fined and 1,000 lakh Afghanis collected from them. They are also ordered to supply wheat and rice to mujahideen. Cattle and sheep belonging to the well-off people are also taken away on a regular basis to feed the armed mujahideen.

It was learnt that 5,000 tonnes of wheat was thrown into the Kokcha river as it no longer remained fit for human consumption due to its improper storage in commander Najmuddin's godowns in Baharak. The wheat had been donated by UNHCR via Tajikistan for the people of Badakhshan but Najmuddin kept it in his possession instead of distributing it.

THE NEWS INTERNATIONAL

\section{APR 1994}


proceeded to Hasarshahi refugees camp. At Hasarshahi Camp, Mehmood Mistiri went around the camp in a vehicle of the United Nations. He witnessed the miseries and grievances of thousands of Afghan civilians, included most educated and civilised families who are residing in the camp He was also briefed by the UNHCR volunteers about the situation of the camp as well as of the facilities being provided to these refugees by the United Nations' sister agencies and other Non-Governmental Organisations from various countries.

Later, Mehmood Mistiri proceeded to Jalalabad where he attended a meeting of the Nangarhar Shura held with Governor Haji Abdul Qadeer in the chair. Haji Abdul Qadeer and other members of the Shura informed the United Nations Secretary Gener-

\begin{abstract}
al's special representative about their plan for holding a seminar in order to assemble maximum Afghans for building up a consensus for finding out an amicable settlement to the long-awaited Afghan conflict. He was informed by the Nangarhar Shura that in the proposed seminar, they are planning to provide representation to maximum Afghans and they will invite leading figures from 30 provinces of that country.

Meanwhile an Afghan elder Yar Mohammad Khan from Qandhar told this correspondent that the United Nations Secretary General's special representative Mehmood Mistiri assured the Afghan elders from Southern border province of Afghanistan to undertake a detailed visit to Qandhar and Quetta to know about the sentiments of the Afghans. He is
\end{abstract}

likely to visit the Southern province after completing his trip in Peshawar
and Kabul.

Yar Mohammad Khan who has recently completed a two-month long tour of 28 provinces of Afghanistan said that after coming to know about visit of Mehmood Mistiri to Islamabad, the elders from various southern provinces of Afghanistan have held their gathering at Quetta and he was nominated as a representative of the assembly for finalising the schedule of Mehmood Mistiri's visit to the Southern provinces.

Answering a question, Yar Mohammad Khan said that Jehadic forces did nothing except destructing Afghanistan and killing of innocent and helpless people. He said that they welcome the United Nations peace initiatives and hopeful of its

\section{NATION \\ 01 APR 1994}

\section{positive results. He said that it was crystal clear that Jehadic leaders are unable to restore peace in war devas- tated Afghanistan, therefore, they need to realise their failure and let the United Nations for resolving the con- flict in the light of aspiration and wishes of the silent majority of that country. \\ When questioned about the role of former King Mohammad Zahir Shah, the tribal chieftain said that majority of the Afghans not only consider the former King not only a neutral per- son but also consider him a symbol of national unity. He said that United Nations need to provide maximum opportunity to the former King of playing his due role in the efforts aimed at resolving the conflict and to save Afghanistan from further de- struction and bloodshed. \\ UN team may visit Kabul tomorrow}

\author{
Bureau Report
}

PESHAWAR, March 31: A UN observers mission will leave for Kabul to monitor the situation in the Afghan capital after the warring factions agreed to a five-day
ceasefire. Accordin

Peshawar to sources in missionar, the decision to send the mission has been taken in consulta. tion with the officials of the Afghan factions but the mission may pro. ceed to Kabul on Saturday after clearance is received from the $\mathrm{Rab}$. bani government.

Meanwhile, after a comparative calm in Kabul in the day sporadic fighting erupted in Pule Mehmud Khan in the afternoon as rockets
and shells were fired which killed six people and injured 16 others.

Fighting in northern provinces of Baghlan, Faryab and Kuduz is also reported to be continuing between the lovalists of Rabbani and the coordination forces led by Hezbe Islami and Rashid Dostum. 


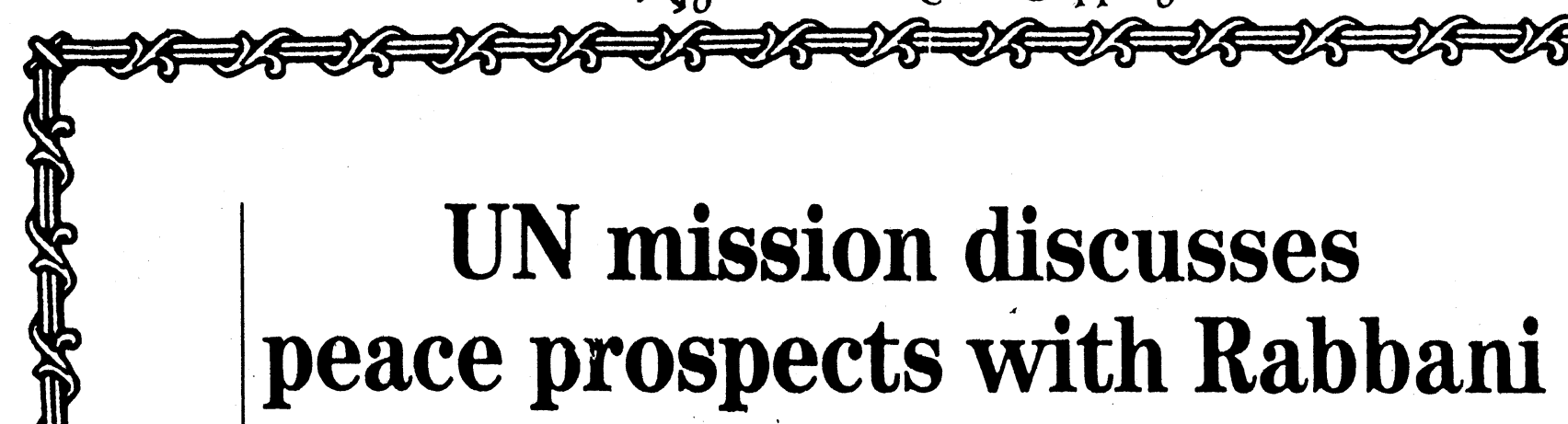

\section{Reuter}

KABUL: A UN peace missiun me Arghan President Burhanuddin Rabbani on Saturday to try to 1:: gotlate an end to nearly two years if fac. tional battles that have killed 11,000 people and rendered tens of thousands homeless.

Both Rabbani and his arch-rival Prime Minister Gulbuddin Hekmatyar, who launched his latest battle to topple the president on January 1 , agreed to a ceasefire during the three-day visit by the five-member UN mission. "Finding a solution is the main, if not the only, aim of our visit," the mission leader, former Tunisian foreign minister Mahmoud Mestiri, said on his arrival from Pakistan at an airbase north of Kabul.

Mestiri held three hours of talks with Rabbani and sald later he had a clearer view of the president's position but was unable to say if he had made progress towards a listing peace. "We had very good anilysis of the situation and the position of Rabbani, the way he sees the purblem and certainly his position for peace and an Immediate and total cease. fire...If that is possible," Mestiri sald.

"My government is in favour of a lasting ceasefire and not only one for the duration of this visit," Rab). bani told reporters. Mestiri met three other leaders of mujahideen factlons in the quarrelsome Islamic coalition government that took power from the former Sovietbacked communist government in Aprl, 1892, after 14 years of civil war. He is the most senior UN official to visit Afghanistan since the guerrillas came to power.

Outside the presidential palace, a group of children had gathered, saying they wanted an immediate end to the fighting. Demonstrators in the west of the city waved signs reading "Peace" as Mestlil passed. "Down with fighting, down with fighting," one man shouted. Mestiri is due to meet Hekmatyar at his base in Cha. rasyab about $20 \mathrm{~km}$ (12 mlles) southeast of Kabui early today.

Early on Saturday, three rockets slammed into the Rabbani-held Television Hill near the city centre but the ceasefire later took hold across

Kandahar shura invites UN team to visit Afghanistan

From Our Correspondent

PESHAWAR - The Kandahar Shura ruling the Southern parts of Afghanistan, through a letter asked the UN's peace team headed by Mehmood Mestiri to visit Kandahar for knowing wishes and sentiments of the Afghans for resolving the conflict through peaceful and political ways. Abdullah Popalzai told newsmen here on Saturday that he on behalf of the Shura had sent a letter to $\mathrm{Mr}$ Sotorous Mosourous, special representative of the United Nations for Afghanistan. He said, the letter was signed by a number of elders from Qandahar Province including its Governor Agha and others. Abdullah Khan Popalzai said that Kandahar Jirga through its letter, informed the UN's team that they favour the proposals of former King Zahir Shah for resolving the Afghan conflict through an emergency Loya Jirga. the war-shattered capital. Bu,th sides traded volleys of rocket and artillery fire on Friday but no details of ca. sualties were available. A fierce har. rage of rocket fire from forres led by Hekmatyar pounded Kabul the day before, killing at least two people and injuring more than 70 , hos pitals said. Each side blamed the other for launching the fighting.

More than 11,000 peopie have been killed in the power struggle for Kabul since the guerrillas entered the city in April, 1992. Mestiri new on Wednesday from Pakistan to the eastern Afghan town of Jalalabad, where he visited camps that house an estimated 110,000 internal refugees who have fled there from Kabul since the latest battles erupted on the New Year's Day.

Mestiri's mission aims to seek the views of a broad spectrum of Afghan leaders on how the United Natlons might best help with na. tional reconciliation, UN officials said. Hekmatyar is insisting that Rabbani must resign to make way for an interim government (1) oversee elections.

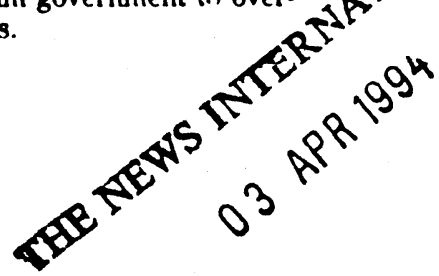

NATION

O3 APR 1994 


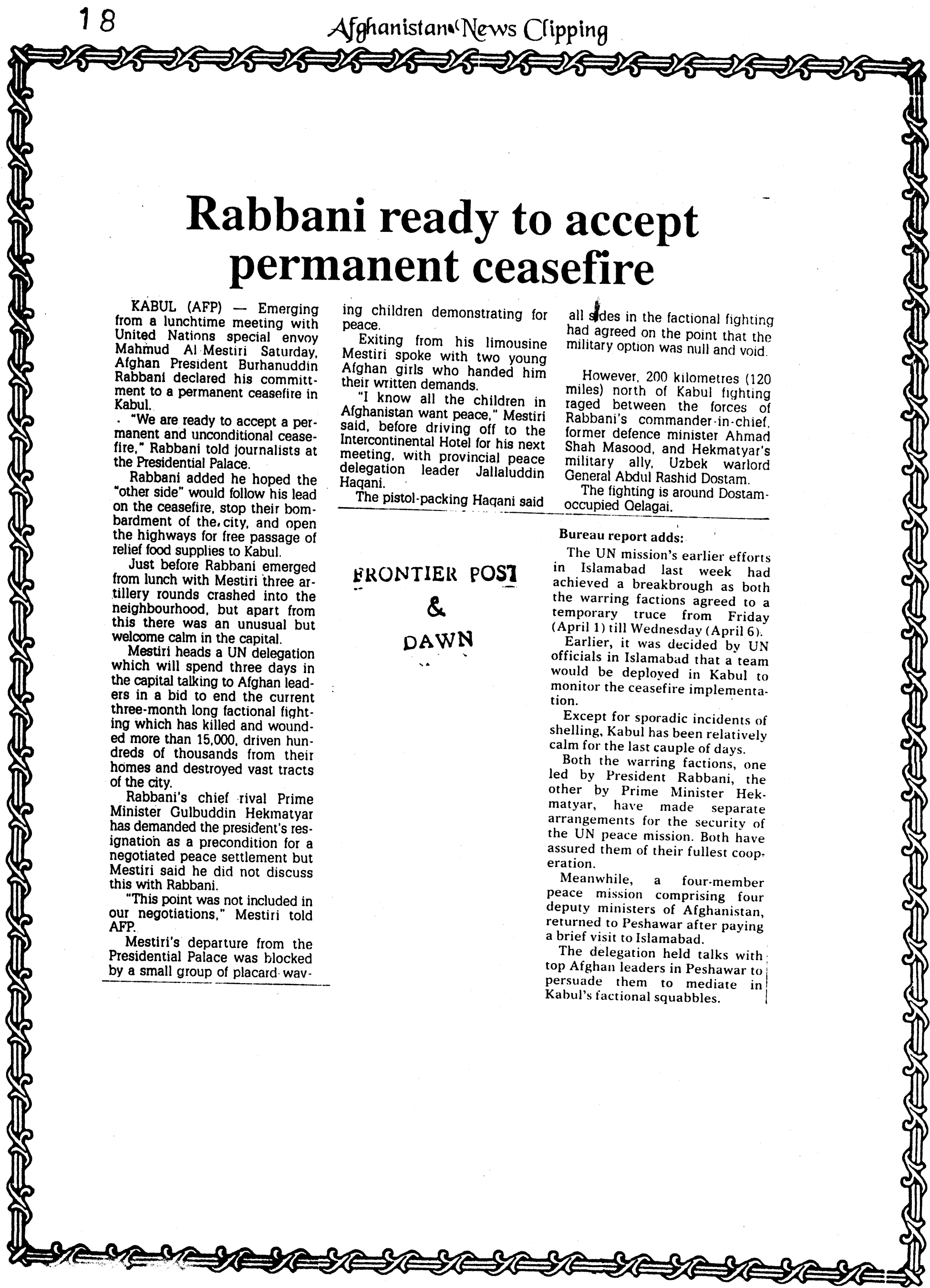




\section{Hekmatyar says no to Mestiri's ceasefire call}

\begin{abstract}
AFP
CHARASIAB: United Nations special peace envoy to Afghanistan, Mahmud Mestiri failed Sunday in his bid to achieve a concrete declaration of a permanent ceasefire from Prime Minister Gulbuddin Hekmatyar.

"From our side we have already accepted a ceasefire but the problem is that the other side is not respecting it," Hekmatyar replied ambiguously when asked about his position on a permanent ceasefire.

A temporary ceasefire had been agreed by the main factions in the latest round of fighting in Kabul, going on since January 1 , to enable Mestiri's UN mission to visit the capital.

Afghan President Burhanuddin Rabbani had on Saturday stated clearly his commitment to a "permanent and unconditional ceasefire". Hekmatyar for his part is still demanding the resignation of Rabbani as a precondition to permanent peace in the war-torn capital. "The resignation of Rabbani is a must for peace and reconciliation," Hekmatyar told assembled journalists at a press conference in his Charasiab headquarters 25 kilometres south of
\end{abstract}

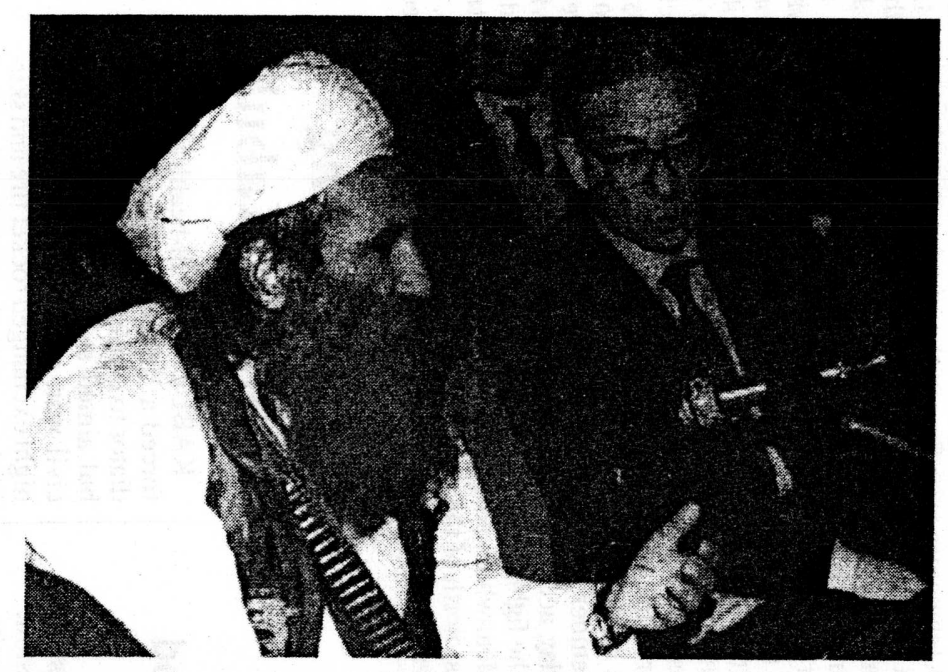

Mahmud Al-Mestiri (R), United Nations special peace envoy to Afghanistan, exchanges views with bandoleer-packing Mujahideen peace delegation leader Jallaluddin Haqani at Kabul's Intercontinental Hotel. -AFP photo

Kabul, following his meeting with Mestiri. atyar replied negatively in expected to meet with Rabbani's United Nations role in the collection Ahmad Shah Masood on Monday, of heavy weapons in the capital. "We and is understood to be returning to are not accepting the delivery of Pakistan Tuesday. weapons to any foreigners. We pre-
Our Peshawar bureau adds: Me- stiri's visit to Hekmatyar's headquarters coincided with factional fighting in Tagab valley near Kabul. Breaking the news of the eruption of fighting in Tagab, Kapisa province, Hekmatyar in an interview with BBC Pashto Service accused the RabbaniMasood forces of attacking his positions.

Tagab was the scene of furious fighting for about two months recently between forces loyal to the Afghan President and the Prime Minister.

Mestiri and his delegation also met leaders of the Supreme Coordination Council at the Darul Aman Palace in Kabul. Beside Hezb-i-Islami (Hekmatyar), the Supreme Council includes Gen Rasheed Dostum's Junbush-i-Melli Islami Afghanistan, Prof Mojadeddi's Afghan National Liberation Front, and the Shiite Hezb-iWahdat.

It was also learnt that a demonstration was staged in Charasyab on Sunday on the occasion of Mestiri's visit. The demonstrators, claiming hey were refugees from Kabul city, demanded resignation of both Rabbani and Hekmatyar and said they want peace.

\section{THE NEWS INTERNATIONAL}

04 APR 1994 


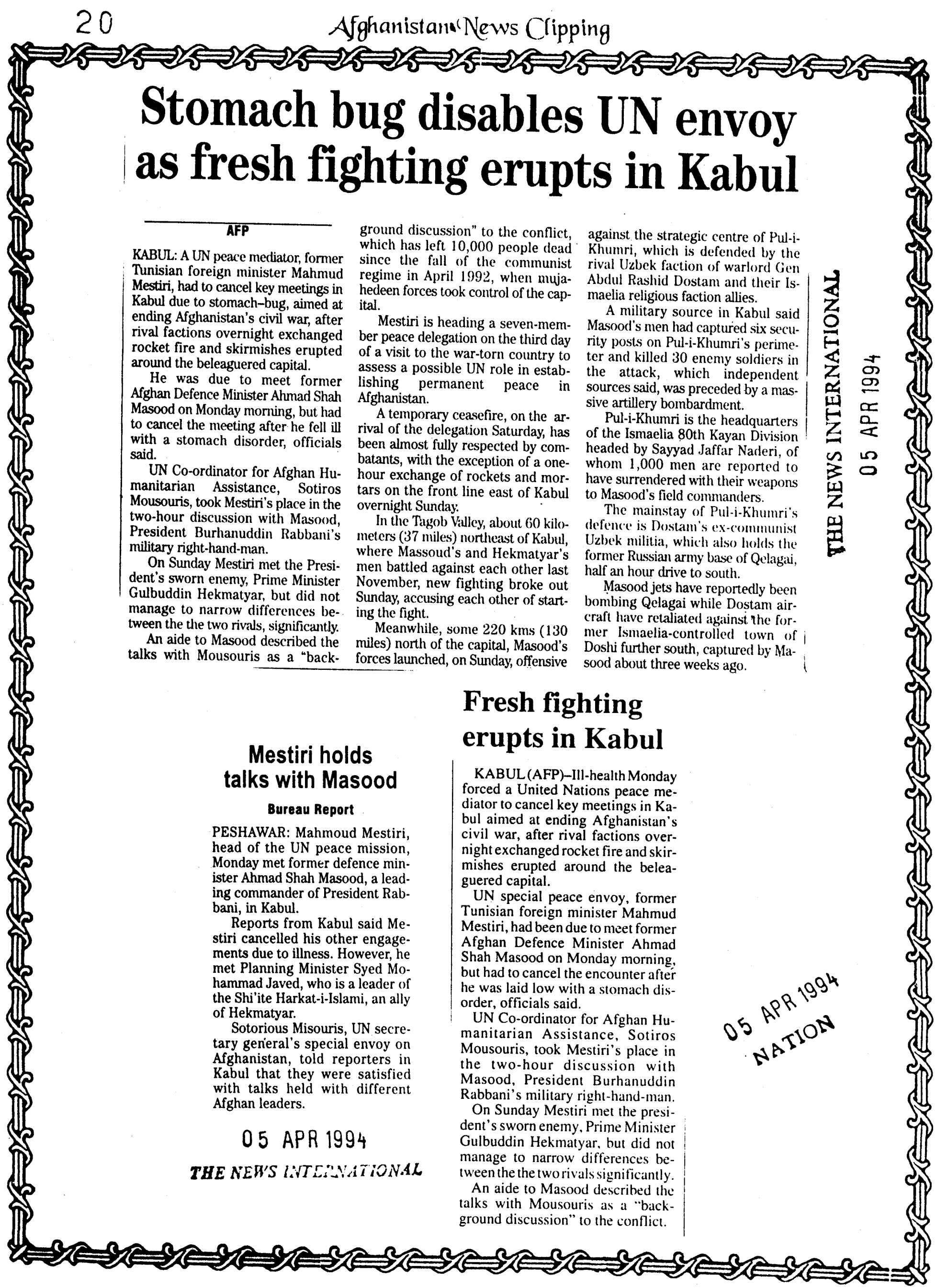




\section{Mestiri arrives in Peshawar today}

along with his colleagues will hold detail talks with former Afghan president and chief of Afghan National Liberation Front Prof Sibghatullah Mujaddedi and moderate Afghan leader and Chief of National Islamic Front of Afghanistan Pir Syed Ahmad Gillani. On the second day, $\mathrm{Mr}$ Mehmood Mestiri will hold meetings with chief of his faction Maulvi Mohammad Younas Khalis and Harakat Islami chief Maulvi Mohammad Nabi Mohammadi.

During his stay in Peshawar, $\mathrm{Mr}$ Mehmood Mestiri will also hold detailed talks with various bodies and organisations of moderate Afghan intellectuals, ulema, tribal chieftains, commanders and individuals who

\section{Mestiri holds talks with Afghan leaders}

\section{From Our Correspondent}

PESHAWAR - United Nations' Secretary General's Special Representative Mr Mehmood Mistiri spent a very busy day in Peshawar on Saturday and continued dialogues with leading Afghan leaders in a bid to find out an amicable settlement to the conflict.

Mr Mestiri accompanied by UN envoy for Afghanistan $\mathrm{Mr}$ Sotorous Mousorous and other UN officials after their arrival in Peshawar entered into meetings with former Af ghan President Sibghatullah Mujaddedi, moderate Afghan leader Pir Syed Ahmad Gillani, Maulvi Mohammad Younas Khalis and others.

Talking to newsmen later, Mestiri and Prof. Mujaddadi termed their talks fruitful and positive. Mr Mehmood Mestiri said that he wanted to enable the Afghans for resolving the conflict through peaceful and political ways. He expresed satisfaction over his talks with Prof. Mujaddedi and hoped that in the light of his experience, he would reach a conclusion.

Prof. Mujaddadi while commenting on his talks with Mr Mehmood Mestiri said that he welcome the United Nations efforts for resolving the conflict. He said that he and his party always had welcomed the United Nations efforts. He said that he apprised Mr Mehmood Mestiri of his proposals and suggestions for resolving of the Afghan conflict in the light of aspirations of the Afghans.

Similarly, Mr Mehmood Mestiri held an hour long meeting with chief of his faction Maulvi Mohammad Younas Khalis in the latter's party office at Katcha Garhi Afghan refugee camp. Both of them exchanged views on current uncertain situation of Afghanistan and discussed various proposals for resolving the conflict.Later in the afternoon, $\mathrm{Mr}$ Mehmood Mestiri alongwith his colleagues entered in to a meeting with moderate Afghan leader and chief of National Islamic Front of Afghanistan Pir Syed Ahmad Gillani in the latter's residence situated on Warsak road.

The meeting lasted for half an hour and beside the United Nations team it was also attended by $\mathrm{Dr}$ Gran, $\mathrm{Dr}$ Syed Hamid Gillani and others. Pir Syed Ahmad Gillani informed $\mathrm{Mr}$ Mehmood Mestiri about the wishes of silent Afghan majority who was desirous for an early ceasefire and an end to the bloodshed and destruction in their motherland. desirous for an early peace in their motherlands and favours formation of a broad based interim government in Kabul replacing Rabbani administration. In this connection, these moderate Afghans have prepared texts of the peace formulae which they will hand over to Mehmood Mestiri and his colleagues.

It may be mentioned here that majority of the moderate Afghans are residing in Peshawar, therefore, they are giving much importance to Mehmood Miesiri's visit to Peshawar. Both Pir Syed Ahmad Gillani and Maulvi Mohammad Nabi Mohammadi are also supporting proposals of the independent and moderate Afghans who enjoy support of the majority of Afghans.

\section{Snow storm traps UN envoy in Kabul}

KABUL (AFP) - A freak snow storm swept Kabul Tuesday, closing the military airport used by the Unite Nations and stranding its special envoy Mahmoud Mestiri in the Afghin capital, a UN spokesman said.

Mestiri, who is recovering from the stomach ailment which kept $h$ on confined to bed for one and a half days, was due to fly to Islamabád Tuesday afternoon from Bagram airbase, some 50 kilometres north of Kabul.

The whiteout conditions in Kabul - coming after two weeks of sunby spring weather - were more severe than anything experienced in the winter just passed, said locals.

Security staff accompanying Mestiri said the eight-strong mission, which arrived in Kabul four days ago to assess the UN role in effecting a permanent peace in wartorn Afghanistan, would return to Pakistan Wednesday - weather pármitting.

A UN spokesman said there whe high hopes that the five-day ceasefire arranged for Mestiri's visit would be extended Wednesday, although no official declaration of this offer has yet been made.

NATION

06 APR 1994 
and said peace would be announced within a few days, yet his spokesman John Mert was cautious in this regard and said that one should not attach great expectations with the visit and consultations.

He added that they are in the beginning of their journey and there should be more talks and consultations. he further said that Mestiri is likely to visit Mazar-eSharif and Herat next week.

The spokesman neither ruled out nor confirmed the possibilities of talks with the former Afghan monarch Muhammad Zahir Shah.

In reply to a question about the Loya Jirga, the spokesman said they are making efforts to know as to what is the common aspiration of the people of Afghanistan. He said all Afghans have their own views and plans for the solution of the problem. However, there are also some identical points in their views.

He said one of their jobs is to coordinate such identical points and take immediate step on the basis of these points. The spokesman said that the issue of Loya Jirga is premature. He said now they are listening to the people and any final solution to the Afghan conflict should be found by the Afghans themselves. However, the United Nations would help them in this regard, he said.

The spokesman said that at the end of the visit. Mestiri will submit his report to the UN secretary general and the UN Security Council will also consider it. He said the ongoing situation is not acceptable to the international community.

John Mert said the United Nations wants the Afghans to realise that they are not alone in the crisis and hardship and the United Nations is helping them to put an end to the crisis and start the difficult job of reconstruction of Afghanistan.

\section{Afghian delegation discusses situation with Mestiri}

\section{From Shamim Shal aid}

PESHAWAR - C n the second day of his stay in Peshawar, the United Nations Sec retary General's special representa itive Mehmood Mestiri on Sunday mc rning received a 29-member delegati on of the Council of Understandin $y$ for National Unity of Afghanistal 1 in a local hotel.

The 29-member de legation of the council was headed by Maulvi Tarakhel a renowried religious scholar and Prof. Rasool Amin director of Writers Linion of Free Afghanistan. Other n lembers of the delegation included Gen. Abdul Hakim Katawazi, Con imander Abdul Haq, Haji Mohamma dl Daud, Prof. Hakim Taniwal, Hakini Aryubi, Qazi Amin Wardak, Jamiatullah Jalal, Haji Hayatullah, She hzada Masud, Stana Gul Sherzad, Haji Pacha Khan, Dr Amanullah Rasocill, Dr Yousaf Nooristani, Prof. An vvar Sarwari, Syed Naeem Majroh; Abdul Hadi Qarizada, Ahmad Walli Sarosh, Dr Abdul Rahim F'ushtoonyar, Mohammad Aziz Askarzada,
Ghulam Hassan Khan Karokhel, Prof. Dr Mohammad Tahir Burgai, Ibrahim Rajab, Zahir Khan Jabarkhel and others.

Mehmood Mestiri during his one and half an hour talks with the members of the council was assisted by United Nations special envoy for Afghanistan $\mathrm{Mr}$ Sotoroius Mousorous and other members of the team. Both the sides exchanged views on the current efforts of United Nations aimed at finding out an amicable settlement to the long awaiting Afghan conflict through peaceful and political ways. The United Nations Secretary General Mehmood Mestiri apprised the members of the council about efforts of his team and said that United Nations just wanted to help the Afghans for resolving their problems at their own.

He made it clear that United $\mathrm{Na}$ tions has no intentions to impose a formula on Afghans but they want to enable the Afghans to build up a concensus on an acceptable and applicable formula in a bid to bring an end to ongoing uncertain situa-

\section{tion in Afghanistan.}

The members of the Council for understanding for National Unity of Afghanistan, while welcoming Mehmood Mestiri and his colleagues in Peshawar apprised him about functions and activities of the council.

On behalf of the council members, Maulvi Tarakhel, Prof. Rasool Amin, Mohammad Hakim Aryubi and Dr Amanullah Rasool made comprehensive statements before the United Nations peace mediators.

They discussed in depth their views on current situation of Afghanistan and expressed concern over unrealistic approach of the Jehadic forces and their patron towards war devastated Afghanistan.

Later, Mehmood Mestiri proceeded to Islamabad for attending a lunch hosted in his honour by President Sardar Farooq Ahmad Khan Leghari.

He likely to return arrive Peshawar Sunday night and will resume his meetings with Afghans from Monday morning. 


\section{Afghan delegation presents written peace formula to Mestiri}

\begin{abstract}
From Behroz Khan
PESHAWAR: The United Nations special envoy on Afghanistan, Mehmud Mestiri, Sunday continued his meetings with various Afghan groups and personalities for the second consecutive day here to evolve consensus on the Afghan issue.

A 30-member delegation of Council for Understating and National Unity of Afghanistan (CUNUA) also met the UN envoy before he rushed to Islamabad in the afternoon

Mestiri, who flew to Kabul last week to negotiate a new cease fire between forces loyal to Afghan President Burhanuddin Rabbani and Prime Minister Hikmatyar is in Pakistan trying to workout a formula for the restoration of lasting peace in that war-torn country. His dash to Kabul however, bore no fruit as none of the warring sides give any concrete as surance to him regarding their support in the renewed peace process.

The CUNUA delegation, headed by renowned religious scholar, Maulavi Tarakhel, presented the UN envoy with a written peace formula for the
\end{abstract}

resolution of the conflict gional UN envoy were busy in promotin their own political motives which thought was the major hurdle in the peace process

The members of the delegation criticised all the previous accords reached in Peshawar, Islamaba alalabad and termed it foreign sponsored agreements whose authors in tentionally deprived Afghans of their inalienable right of self determina tion.

The demands put forward in the peace formula calls upon the UN to take measures for the convening of a true representative Loya Jirga to ha

It also said that leaders of the ring factions should be persuaded to relinquish their illegal slots in response to the popular demand and transfer power to a non-partisan commission, comprised of Afghan of high calibre.

The proposed commission would prepare the ground for convening an emergency Loya Jirga or a representative gathering of commanders,

tribal elders, religious scholars and educated Afghans under the auspices of the UN which would elect a pretransitional caretaker administration. The Jirga, it thought, would provide the base for a cooling off period to be followed by intra-Afghan dialogue be reconciliation and rapprochement in the first phase which should exced more than a year.

The second phase, it said, would start with the convening of Loya Jirga which would represent a broad spectrum of Afghan society to elect an interim government to be entrusted with the responsibility to hold fair free and impartial elections in Afghanistan with in a year's time. UN Security Coun un's time. The inpecurity Council, it said, should inse appropriate sanctions on factions defying a political settlement to be worked out through the good offices of the world body.

Mestiri also held detailed meetings with the delegations of Grand $\mathrm{Na}$ tional Unity of Afghanistan, headed by Shahzada Masoud, Afghan Milat by Stana Gul Sherzad and the delegation of Jamaat Dawat ua Suniah from narh province.

\section{Afghan delegation calls on Mistiri}

A 30 -member delegation of the Council for understanding and National Unity of Afghanistan held a meeting with the head of the UN special mission, Mehmood Mistiri Sunday morning, says a press release.

during the meeting certain members of the delegation including Maulavi Tarakhail, renowned religious scholar, expressed their views on the ongoing bloody conlict.

Members of the delegation in their remarks inter alia brought to light the continued foreign interference in the internal affairs of Afghanistan as well as efforts onthe part ol outside circles to create hurdles in the way of the resumption of the UN peace pro-

ERONTIER POST

11 APR 1y:4

THE NEWS INTERNATIONAL

11 APR 1994

3 


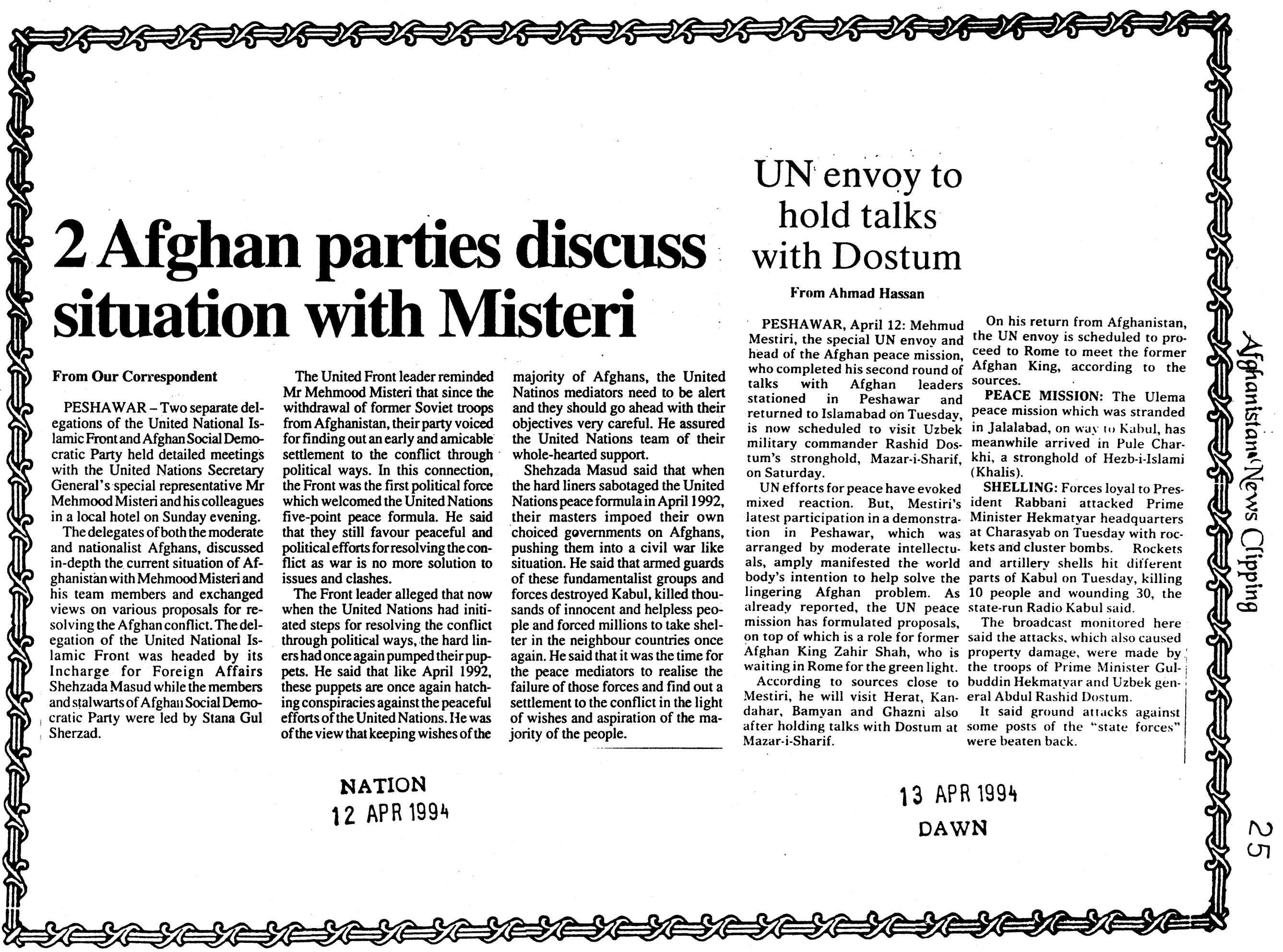




\section{6}

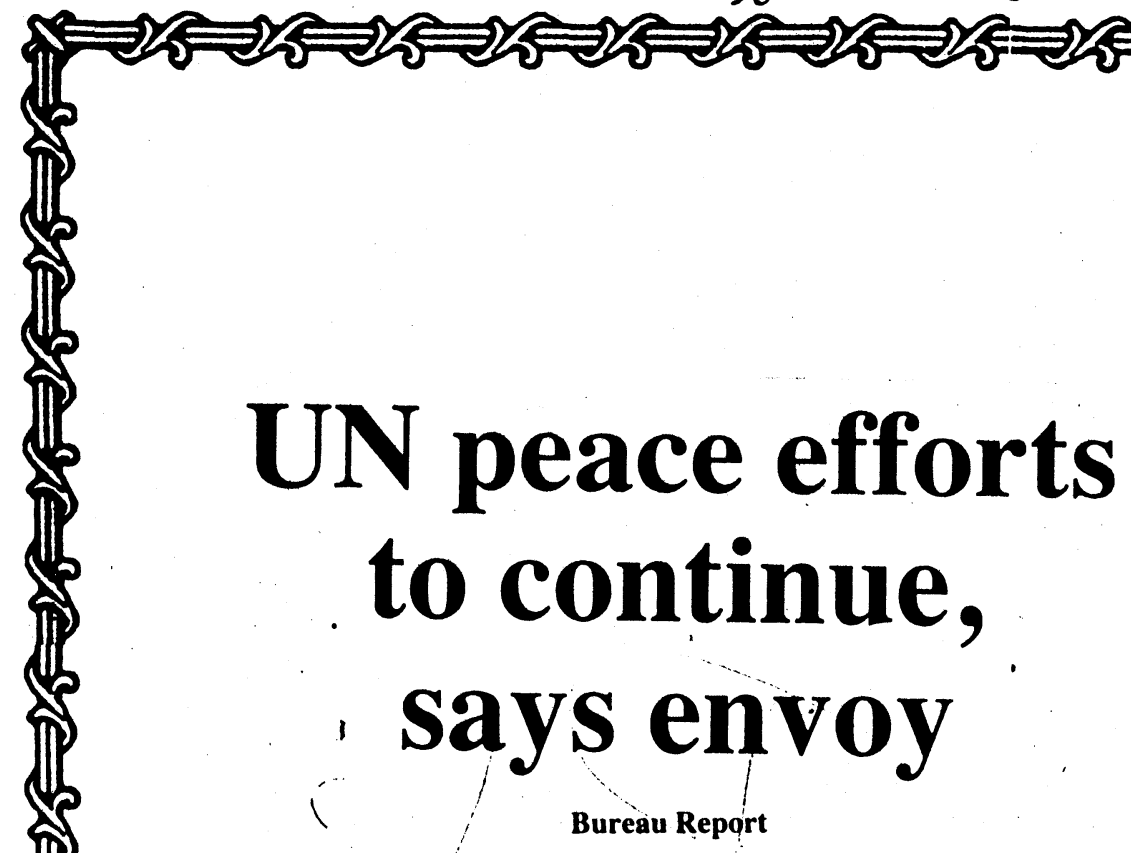

PESHAWAR, April 12: The UN Secretary-General's Special envoy for Afghanistan, Mr Mehmoud Misteri, has said that he was keen to continue his peace mission in Afghanistan. He said that he had been encouraged by the support he had received from all sections of Afghan people.

Addressing Afghan displaced persons, who peacefully demonstrated in front of the office of UN High Commission for Refugees in the University Town here on Tuesday morning, the UN envoy informed them about the peace efforts being done by the United Nations in a bid to resolve the conflicts through holding talks with different Afghan political elements, involved in the ongoing fighting.

He believed that Afghan wanted restoration of peace in their motherland, adding the UN would continue its efforts for everlasting peace.

The UN envoy appreciated the sentiments of the displaced persons, who wanted reconstruction of their motherland, and hoped that very soon they would achieve their goal by establishing an elected gov. ernment in their country. He further said that the UN mission had come here to listen to every Afghan in order to find out the real causes of the crises.

While talking to mediamen on this occasion, Mehmoud Mistiri said he had been encouraged to go dhead with his peace efforts as it

was not the only desire of United Nations but also of millions of war. affected people, who were supporting him.

He said that the demonstration had proved that majority of the Afghan displaced persons was not only interested in restoration of peace in their country, but also wanted to return to their home. land, so as to play their role in the future political process as well as building up their devastated land.

Earlier, hundreds of Afghan displaced persons living in different refugees camps in and outside the provincial capital taking advantage of the visit of the UN special envoy for Afghanistan Mehmoud Mistiri, held a demonstration outside the office of UNHCR, urging the UN to play its role in restoration of peace and establishment of central neutral authority in Afghanistan.

He received a memorendum, demanding early peace in the war. torn country through formation of an interim government and convening an emergency meeting of the Afghan traditional forum (Loya Jirga) to decide the political destiny of the people.

The demonstrators chanted slogans against the role of Mujahideen leaders and demanded of both the President Rabbani and Prime Minister Hekmatyar to immeditely resign from their offices as they were "directly responsible for the ongoing bloodshed".

\section{Mestiri deplores fresh fighting in Kabul}

ISLAMABAD (APP) - The Head of the Special Mission, Ambassador Mehmoud Mestiri ' on Tuesday deplored the tragic news from Kabul but said he would not be deterred and that such attacks only gave new emphasis and urgency to the UN's mission to bring peace, says a Press release issued here.

Addressing a rally of 2,000 Afghan refugees in Peshawar, he said "We hear there is war in Kabul. Let them make war, we will make peace. We can read in your eyes and your attitude your determination to have peace. Our determination is equally great". Fearing an intensification of the fighting, he had asked the warring factions in Kabul to extend the ceasefire agreed for the visit of the Special Mission. Although they had not agreed to a formal extension, there was a 10 day respite in the fighting which has revaged the Afghan Capital over the past three months. The Special Mission has spent the past four days in Peshawar, hearing the views of a wide range of Afghans including several women's groups. On Saturday, the mission will begin its third visit into Afghanistan with meetings in Mazar-i-Sharif, Herat and Bamiyan. Other centres, including Kandahar, will be visited later in the mission.

\section{NATION}

13 APR 1994

\section{DAWN}

13 APR 1994 


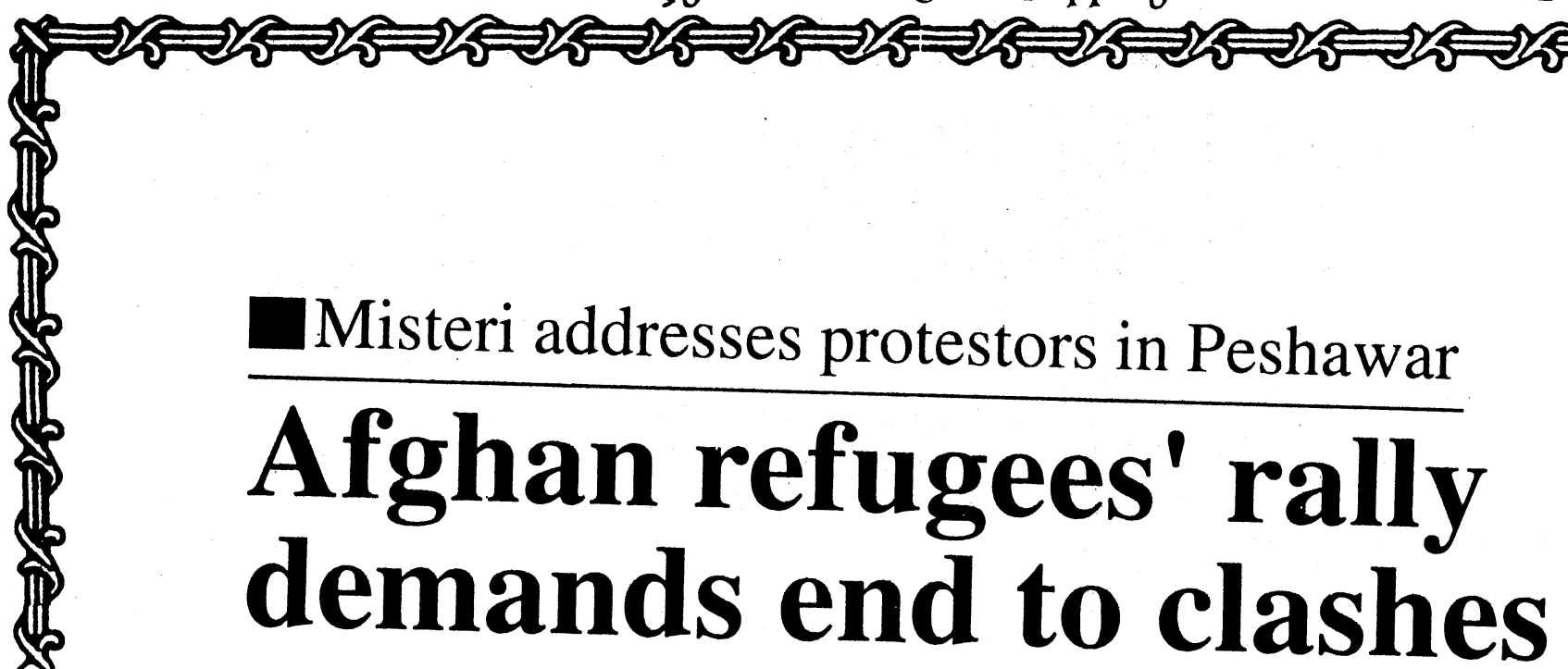

From Shamim Shahid

PESHAWAR - For the first time since December, 1979 hundreds of Afghans including Mujahideen, affiliated with various Afghan Jehad forces, staged a demonstration demanding an end to fighting and restoration of peace in their motherland, in front of the United Nations High Commission for Afghan Refugees in University Town on Tuesday morning.

The Afghans staged the demonstration at the time, when United Nations Secretary General's special representative Mr Mehmood Misteri was present inside the office. Mr Mehmood Misteri accompanied by Mr Sotorous Mousorous and other members of his team have not only received the peaceful protestors but also addressed them highlighting objectives of the United Nations which is an end to ongoing fighting and restoration of peace in Kabul.

Mr Mehmood Misteri when came to know about arrival of hundred of Afghan protestors in front of the UNHCR office, came forward and he held detailed talks with leaders of the protestors. Mr Abdullah Ghamkhor, a known poet handed over a text of the declaration to MR Mehmood Misteri, in which the Afghto in Afghanistan through formation of an interim government and convening of an emergency meeting of the traditional Loya Jirga. On this occasion, he was also informed about wishes of the protestors by Prof Rasool Amin, Syed Waez Hussain, Syed Ishaq Gillani, Gen. Hakum and other leaders. Addressing the protestors outside the NHCR office in University Town, Peshawar, the United Nations Secretary General's special representative Mr Mehmood Misteri said that he can feel sentiments of these hundreds of people who are desirous not only for an end to ongoing fighting in Kabul but also for the restoration of peace. He said that Afghans are not alone in their struggle for peace in their motherland but they would enjoy whole hearted support of the United $\mathrm{Na}$ tions. "We can read your eyes and determination for peace and UNO is with you" he remarked. Misteri from the top of a Datsun vehicle said that their efforts should be appreciated at the time when fighting is in progress at Kabul. He said that he was deeply impressed from sentiments of these hundreds of protestors who are demanding peace in their motherland and are struggling for the solidarity of their motherland.

Astonishingly, Mr Mehmood Misteri when invited for a brief address, proceeded towards a Datsun pick up for addressing the protestors through laud speaker installed in the pick up. He climbed over top of the pick up and look megaphone in his hand. He was assisted by one of his colleagues with translating his English speech in to Darri. Before, addressing the protestors MrMehmood Misteri shook hands with a large number of Afghans. Majority of these people asked for immediate and direct involvement of the United $\mathrm{Na}$ tions in war devastated Afghanistan. Concluding his speech, MrMehmood Misteri chanted the slogan of "long live Afghanistan".

Talking to mediamen, $\mathrm{Mr}$
Mehmood Misteri said that he was once again encouraged to go ahead with his assignment, witnessing hundreds of war displaced people demanding peace in their motherland. He said that it was proved that majority of the Afghans are not only desirous for an end to fighting in their country but they also want return to their motherland. He said that he had read emotions of these peace-loving Afghans and appreciate them.

Prof Rasool Anin, Abdullah Ghamkhor and Abdul Hassan Waez in their brief speeches welcomed the United Nations team in Peshawar and hoped that the United Nations would soon take practical steps of resolving the conflict. They said that Afghans are really desirous for peace and demanding settlement to the conflict through Loya Jirga, formation of broad-based interim government and for this purpose they support the United Nation.

Earlier. Hundreds of Afghans from every sphere of life and irrespective of their Jehadi and Political affiliations assembled in Speen Jamaat. The protest demonstration was orgnaised by leading Afghan moderate figures like Prof Rasool Amin, Syed Ishaq Gillani, Shehzada Masud, Dr Amanullah Rasool, Gen, Hakim Katwazi, Haji Daud, Hakim Aryubi and others. Before proceeding in a procession tuwards the office of UNHCR, the protestors offered Fateha for the departed souls of all those who had lost their lives in Afghanistan, and prayed for early restoration of peace in their motherland. The Fateha programme as per Afghan traditions was continued for around one hour. 


\section{Mestiri not deterred by blitz on Kabul}

From Rahimullah Yusufzal

PESHAWAR: While fighting erupted in Kabul between Afghan combatants on Monday, the UN peace mission's head Mehmoud Mestiri continued his meetings here Tuesday in a bid to explore ways of bringing an end to the bloodshed in Afghanistan.

The 65-year old Mestiri met delegations of Afghan women, the Shi'ite Hezb-i-Wahdat, Shinwari tribal elder and Afghanistan's refugees repatriation minister Dr Farooq Azam on Monday. He was to continue his meetings on Tuesday before returning to Islamabad, where he was scheduled to brief envoys from European countries on Wednesday.

A press release said Ambassador Mestiri on Tuesday deplored the tragic news from Kabul but said he would not be deterred and that such attacks only gave new emphasis and urgency to the UN's mission to bring peace.

Addressing a rally of two thousand Afghan refugees in Peshawar, Mestiri said: "We hear there is war in Kabul. Let them make war, we will make peace. We càn read in your eyes and your attitude, your determination to have peace. Our determination is equally great.

On Saturday, the mission will begin its third visit to Afghanistan with meetings in Mazar-i-Sharif, Herat and Bamiyan. Other centres, including Kandahar, will be visited later in the mission. A visit is also scheduled to Quetta to meet Afghan refugee elders there. Mestiri, a former Tunisian foreign minister, will also visit Tehran

Riyadh and Moscow to hold talks with Iranian, Saudi and Russian government officials on the Afghan problem before returning to New York to present his report to UN Secretary General Boutros Boutros-Ghali.

John Mills, delegation spokesman, didn't rule out a visit by Mestiri to Rome, Italy, to meet former Afghan king Zahir Shah. He reminded that the mandate of the UN mission was to consult a wide spectrum of the Afghan society and ascertain their vews on how best to resolve the conflict.

"In Kabul and everywhere we have gone the Afghan people have told us, in the strongest terms, that they want an end to the conflict and that they are looking to the United Nations to assist them in this search for peace," Mestiri said.

The UN peace mission, which apart from Mestiri comprises Sotorious Misouris, an economist, a political officer and the spokesman met President Faroog Leghari and Foreign Minister Salar Ass Ali in Islamabad and briefed Islam. abad-based OIC ambassadors about his mission.

Meanwhile, the peace mission of the Saudi-sponsored Muttahida Ulema Council, Pakistan, which left Peshawar on Sunday, was still stranded in Jalalabad. The eruption of stighting in Kabul may either delay or cancel the delegation plans to caph gation is ed by Hezb-i-Islami chief Maulvi Yunis Khalis. Imam of Khana-iKa'aba, who was expected to head the delegation, has returned to Saudi Arabia.

THE NEWS INTERNATIONAL 13 APR 1994

\section{Halt aid to Afghan factions: Mestiri}

ISLAMABAD (AFP) - UN special peace mediator Mahmoud Mestiri said here Thursday that the flow of foreign money to Afghan factions should be stopped to give peace a chance in the war-torn country.

Speaking at a news conference, the former Tunisian foreign minister who visited Kabul last week and met a number of Afghan poand met a number of Afghan political and religious leaders said that there was "widespread support for convening a Loya Jirga, a traditional assembly of the Afghan elders, to resolve the bloody power struggle.

Mestin added that the majority of the people he met desired that "outside interference should end." He believed the warring factions, led by President Burhanuddin Rabbani, his rival Prime Minister Gulbuddin Hekmatyar and Uzbek warlord Abdul Rashid Dostam were fighting for powe

Arms and money are easy for them to obtain, he said adding that the leaders themselves feel they cannot fight forever

"They want to win quickly. The fight may not last months and even the fighters people are fed up.

Mestiri, who was appointed UN Secretary General Boutros Boutros-Ghali's special envoy in February to explore how to bring peace to Afghanistan, said, "We should stop money coming from

He did not identify the source but said he suspected that neighbouring countries are financing the warring leaders.

He also said that "at some stage we have to come to disar- mament, especially the heavy from the have to be coll

"We should lactions. "We should have some kind of peace to start reconstruction, to engage young boys of 16 years of age shooting for money.

Mtresth sald he believed that a "strong movement for peace" in the war-ravaged country will play an important role.

The Afghan people support the UN involvement in the peace offorts which is "very encouraging" for his mission to secure a "permanent" ceasefire, he added.

A religious delegation led by commander Jalaluddin was also engaged in peace and the package suggested exclu sion of the present leaddex in an interim set up he said. , he said.

United stressed that the a solution but not impose come from the Afghan one must Responding Afghan people.

jirga or ranged in the assemblies arcontrod the past had become was held , he said that a jirga would be "differ UN auspices which "diferent from the one which elected Rabbani president

The United Nations would sup. port the participation of represen

Afghanistan, including women, in the jirga, he added.

Mestiri said that many people wanted the former king. Zahir Shah, to return from exile Rome. but not as monarch.

The special envoy is to leave for northern Afghan provinces on Saturday. During his stay he will meet Uzbek warlord Dostam "to convince him to stop fostam "to

He will also thop fighting. and southern provino western leaving for Iran and Saudi Arabia.

Mestiri also said that opposition to Najibullah, who is living under UN protection in Kabul, has dwindled and it may be possible to find a way for him to leave. added that he had not discussed Najibullah with Afghan liscussed Mestiri, who is to submit his report to the secretary general in June, said he will also visit Russia and some neighbouring Russia Asian states Jzbekistan.

FRONTIER POST.

15 APR 1994 


\section{Mestiri-led UN mission leaves for northern Afghanistan today}

From Anwar Iqbal

ISLAMABAD: Hundreds of Afghans sion have demanded a new interim government in Kabul as the only end to the ongoing fighting, a UN spokesman said Friday.

The mission, which returns to Afghanistan today, arrived in Pakistan last month to assess the situation in war-battered Afghanistan for the UN Security Council. It is the highest level UN delegation to visit Afghanistan since the fall of the former Soviet-backed regime in Kabul in April, 1992.

The spokesman said the UN special mission would begin its third visit to Afghanistan with meetings scheduled in Mazar-i-Sharif, Sheberghan, Herat and Bamiyan. The mission will hold a meeting with Abdul Rashid Dostum, a powerful Uzbek warlord who joined Prime Minister Gulbaddin Hekmatyar in the January 1 attempted coup against President Rabbani.

Mestiri also met the two main rivals Rabbani and Hekmatyar, whose rivalry has caused thousands of deaths in Kabul during the last two vears.

Although to a UN press release said Mestiri had constructive exchanges with Rabbani and Hekmatyar, the ambassador described the bands at a news conference he addressed in Islamabad on Thursday.

Apparently, the UN mission is try ing to go beyond the two most powerful groups in Afghanistan and find out how the Afghan people feel about the current situation.

This is a good strategy for a fact inding mission but it may also anno the main Afghan leaders who have the guns and the strength to block any UN move for peace which does not included them, said a Western diplomat in Islamabad.

However the mission appears to be happy with this strategy. The many Afghans who have spoken to the mis sion have expressed their bitterness at the conflict which has frustrate their hopes of rebuilding their counry and their lives, said the UN press release.

According to UN officials, the Afghan have also urged the world cide a future administrative set-up in two rivals as leaders of the armed body to arrange for elections to de- their country.

The interim government, which would hold these elections, should not have anyone from the groups now in power. Instead, it should have neutral Afghans who should hold elections and quit after an elected government in Kabul is formed.

To select the people for the interim government, the Afghans urged the United Nations to call a Loya Jirga or a meeting of prominent Afghans. Such an assembly, they say, should represent all Afghans not just the armed groups fighting for the control of Kabul. The Afghans suggested that the interim government should have one to two years to hold the elections. Some of the groups interviewed by the UN mission also suggested a role for the former Afghan King Zahir Shah who now lives in Rome Not as the king but as a father figure, clarified a UN official attached with the mission.

"So far we have not taken a position on any of these proposals. We are not here for this purpose. We will be here for another couple of weeks to Teheran and Jeddah for furthe talks," he said. listening to the Afghans before we go

\section{Afghans fed up} with infighting: Mestiri

\section{Bureau Report}

PESHAWAR: Mahmoud Mestiri, head of the UN peace mission for Afghanistan, in a very candid comment has described President Burhanuddin Rabbani and Prime Minister Gulbaddin Hekmatyar as "theoretical leaders who are actually the leaders of armed bands".

In an interview with BBC's Daniel Lak in Islamabad on Thursday, he said the people of Afghanistan were fed up with the constant fighting among the mujahideen factions that form the Afghan government. He thought there was a growing peace movement among the Afghans who just wanted to rebuild their lives and their country. Mestiri said his delegation during two-week meetings with the Afghans in both Pakistan and Afghanistan was hearing this message over and over again

Mestiri, who is a former foreign minister of Tunisia, argued that international diplomatic efforts to end the factional violence in Afghanistan was for the first time taking into ac- count the views of as many Afghan as possible. Usually, he said, only the faction leaders were involved in at to get a peace process going. stiri said the people telling him that they were fed up with the constant fighting between Rabbani and his rival, Hekmatyar whose inability to get along had cost thousands of lives since the mujahideen took power in Kabul in 1922.

The UN peace mission head in formed that there were a number of common points in peace plans he had seen so far, such as a tribal gathering or Loya Jirga to choose an inierim government and a possible role for the former king of Afghanistan, Zahir Shah.

Saying that the people wanted the UN involvement, he however pointed out this would not be a military presence because of the historic distrust of the Afghans on foreign soldiers on their soil.

"An eventual settlement could even exclude the faction leaders if this was what the people wanted," Mestiri said.

THE NEWS INTERNATIONAL

THE NEWS INTERNATIONAL 15 APR 1994 


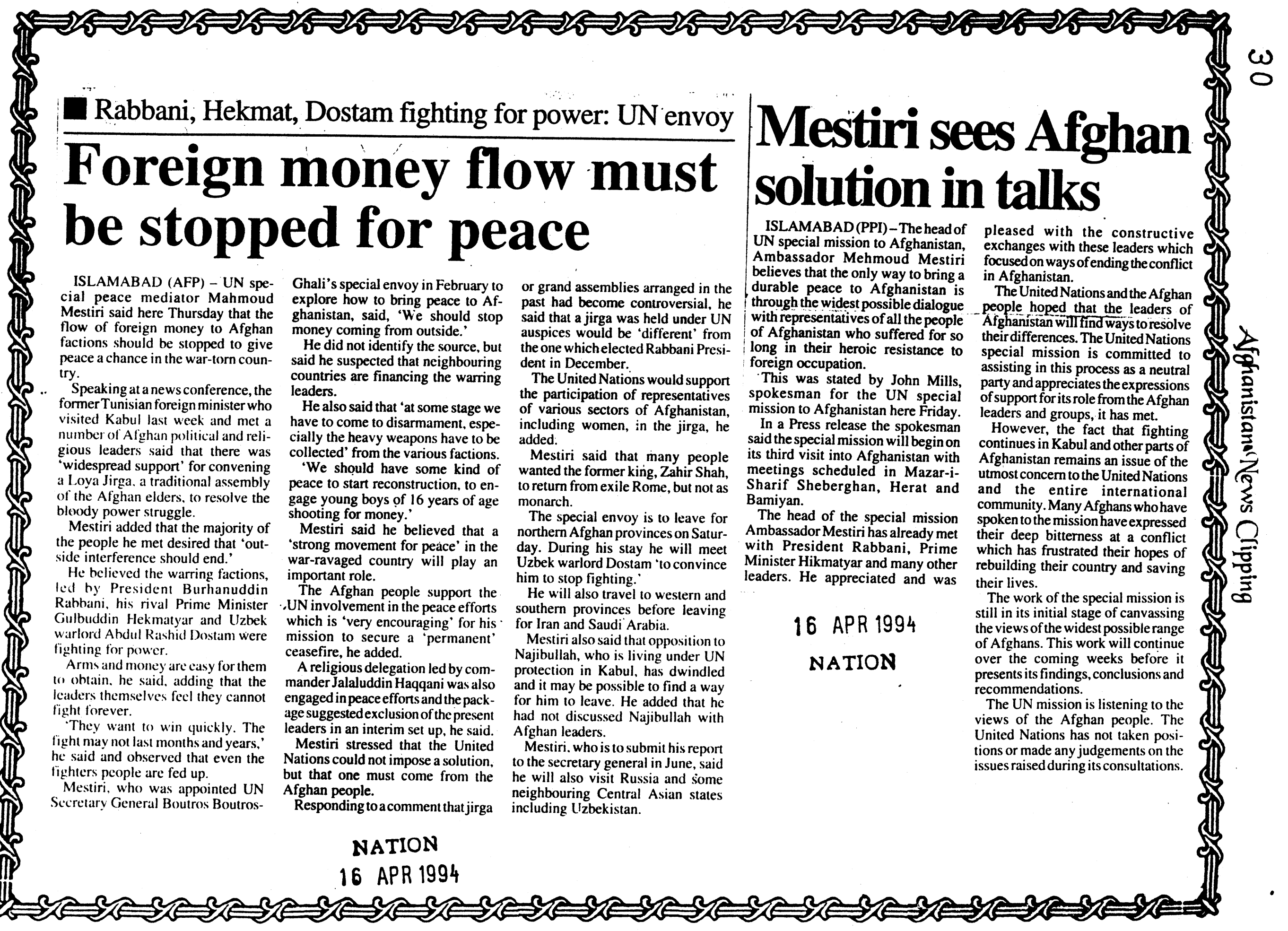




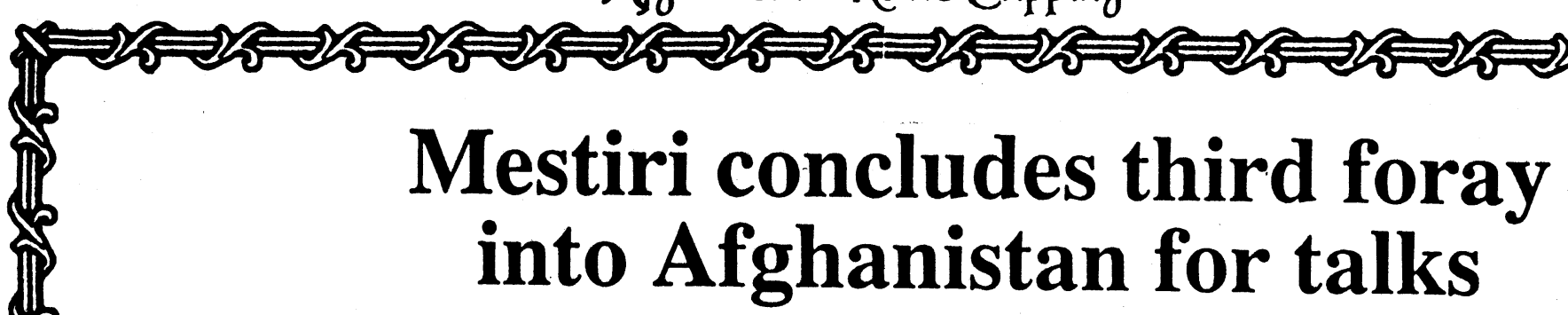

ISLAMABAD (PPI) - The special UN Mission headed by ambassador Mehmoud Mestiri, com. pleted its third visit into Afghanistan Wednesday with a series of meetings in Bamiyan. The special mission spent three

\section{Mestiri given warm welcome in Mazar-e-Sharif}

ISLAMABAD(APP)-A senior envoy of the UN Mehmoud Mestiri has paid a visit to Mazare-Sharif, a stroinghold of Genstal Abdul Rashid Dostum, where he was given a warm welcome. According to a Voice of America report, Mestiri and General Dostum held a brief formal meeting. Mestiri has said that he was , expecting a countrywide ceasefire. General Bostum is quoted to have said that he wants peace and welcomes proposals for establishing peace. Rose petals were showered on the UN Motor convoy in Mazar-e-Sharif. Thousands of people were standing on b6th sides of the road for welcoming the UN envoy. People were carrying placards, in which peace was demanded. On some placards, slongans were inscribed demanding President Rabbani's resignation. Mestiri held long meetings with teachers, doctors, female groups and the Governors of the Northern Provinces.

\section{NATION}

\section{APR 1994}

days in Herat and two days in Mazar-1-Sharif, said a spokesman for the UN special mission to Afghanistan

In Mazar-1-Sharif and nearby Sheberghan. Mestiri had two meetings with Gen Abdul Rashid Dostum including a lengthy private meeting.

One focus of these talks was the urgent need for a ceasefire to relieve the suffering of people in the war zones and also to create a more positive atmosphere for efforts to bring lasting peace.

Mestiri also consulted a group of elders and prominent personali. ties to hear their views on what the United Nations could do to assist efforts to bring peace to Afghanistan and begin reconstruction work.

At the Balkh University, about 1,000 people gathered to give the special mission their views on the situation in Afghanistan. Most speakers emphasised the need for the northern region to be fully included in any new political order. Once again there was strong support for UN role in assisting the peace process. As one speaker put it "we are thirsty for peace".

In Herat, the special mission attended the parade marking the second anniversary of the libera. tion of Herat which was largely peaceful due in part to the successful disarmament programme in the south west region led by Herat's governor lsmael Khan

In his first meeting with the special mission, the governor stressed the importance of collecting weapons saying that wherever there are weapons in the hands of ordinary people. peace cannot prevail there. Other groups in earlier meetings had asked the United Nations to assist in the collection of weapons as an important contribution to peace.

The special mission and local officials had constructive exchange of views on the peace plan proposed by representatives from 14 provinces in Afghanistan.

Mestiri said the plan was practical and should be taken very seriously on its merits and also because it had the support of nearly half the country. It will be closely examined by the special mission. he said.

At the end of the visit to Herat Mestiri and governor Ismael Khan had a working meeting in which they thoroughly examined many of the problems facing Afghanistan and the issues which need to be addressed if there is to be a successful peace process.

In Bamiyan, in the mountainous centre of Afghanistan, the special mission met representatives of most of the Afghan parties as well as hearing the views of the Islamic shoora of Bamiyan. the centre of the Shia minority in Afghanistan.

Mestiri emphasised that the UN could only support a peace process which included all Afghans.

The special mission will go to Quetta on Saturday and will spend Sunday in Kandahar.

\section{FRONTIER POST 22 APR 1994}

\section{Mestiri to brief govt about talks with Afghans}

ISLAMABAD (PPI) - The UN Secretary General's Special Envoy on Afghanistan, MrMehmoud Mestiri will brief government of Pakistan on the outcome of his ongoing talks with the Afghan leaders after he completes the process of consultations for restoration of peace, reconciliation and reconstruction in war-shattered Afghanistan.
A Foreign Officespokesman told reporters during weekly Press brief ing here on Wednesday that Mestiri also held talks with Foreign Minister Sardar Assef Ahmad Ali and other officials of the Ministry of Foreign Affairs at the beginning of his peace mission adding that since then the special envoy had been engaged in consultations with the Afghan leaders.

\section{NATION \\ 21 APR 1994}




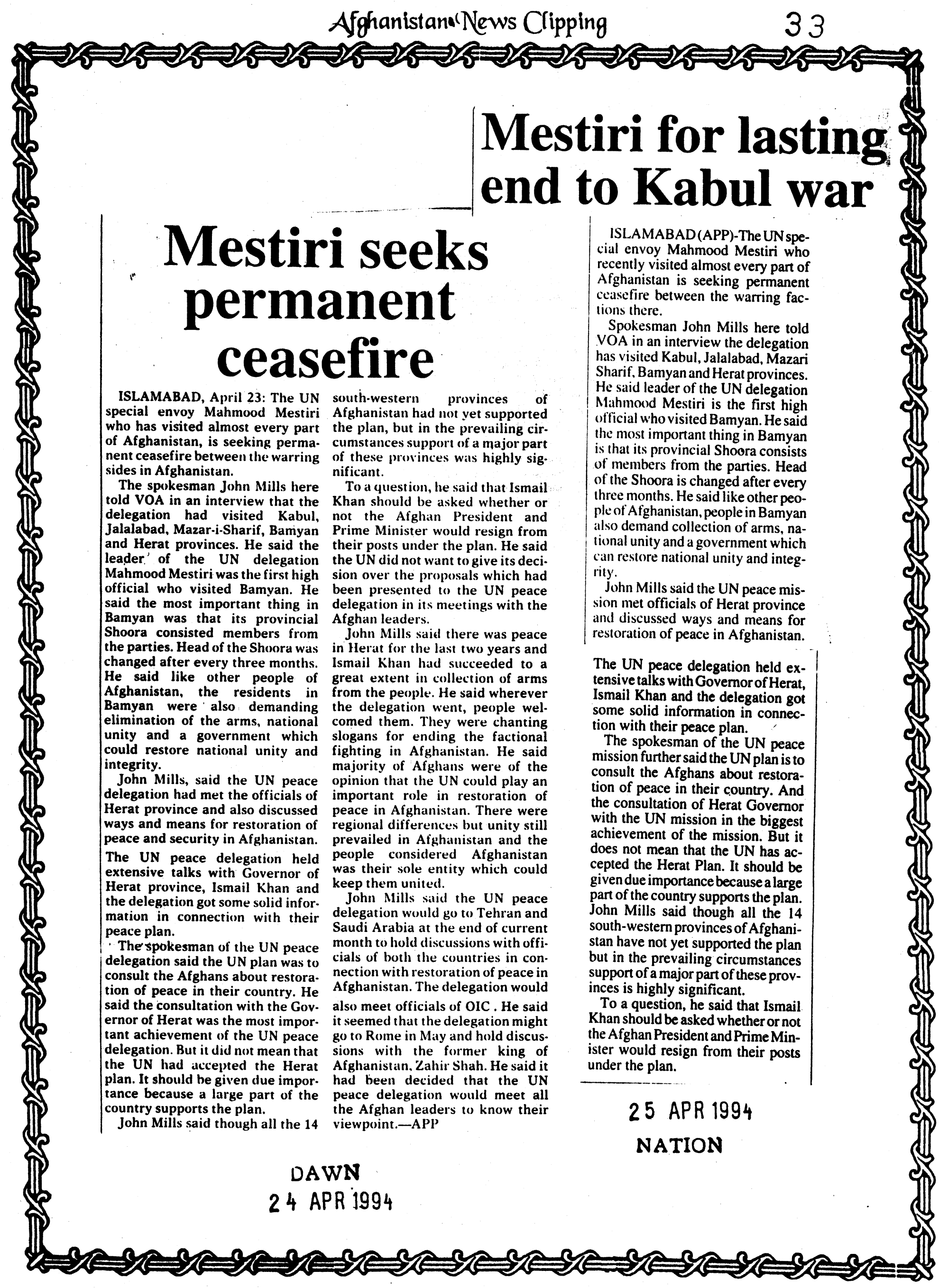


ISLAMABAD (APP) - Slogans Hitevour of loya jirga welcomed the chief of the UN peace mis. sion. Mahmood Mestiri on his arrival in Kandahar on Sunday.

According to VOA report upon his landing at the Kandahar airport, the UN peace mediator, was welcomed by the governor, officials and people of Kandahar province, carry pictures of the former monarch. Zahir Shah and the national flag of Afghanistan.

After watching the protocol parade, Mestiri took part in the meeting arranged at the airport. The participants of the meeting demanded holding of loya jirga for solving problems of Afghanistan. Mestiri assured them of taking into account their proposals and demands. A rally of thousands of people welcomed Mestiri as he arrived in the city. Banners in the rally were inscribed with slogans demanding holding of loya jirga.

Addressing the rally, Kandahar Governor Gul Agha Sherzai said the traditional way of settlement of disputes vogue in Afghanistan since long was the loya jirga which had always strengthened the national unity of the country. He said the jirga was the best option of resolving problems in the present critical situation of
Afghanistan. He referred to the three-point proposal of former King Zahir Shah which called for holding of loya jirga and all kinds of small and heavy weapons should be collected and given under the control of the army. He called upon the United Nations not to leave the Afghan people until a national Islamic govern ment, acceptable to all the Afghans, was formed.

The meeting was also ad dressed by Maulvi Abdur Razaq commander Ramzan Achakzai. Siddiqullah Reshteen and others.

Later, Mestiri addressed the people of Kandahar and said earlier the practice was that contacts were being established with the political groups of Afghanistan but now they were contacting the common people and ascertaining their views and ideas.

He said the emphasis of the UN was that any peaceful solution of the Afghan problem should involve all the Afghan people.

\section{rally greets UN team in Kandahar}

KANDAHAR, April 24: A demonstration in support of exiled ex-king Zahir Shah greeted a UN mission seeking peace in Afghanis$\tan$ when it visited the souther town of Kandahar on Sunday.

tal Kabul, which has been devas. Demonstrators held up pictures tated by two years of factional of the former king as mission fighting since the Mujahideen took leader, former Tunisian foreign power from a collapsed communist minister Mahmoud Mestiri, arrived government.

by air from Quetta in southwestern

Pakistan.

One powerful Kandahar com. The crowd, several hundred mander, Mulla Naqibullah, is from strong according to witnesses, President Burhanuddin Rabbani's shouted slogans in support of the Jamiat-i-Islami party. Another, king, who has lived in exile in Rom Sarkatib, is from the Hezb-i-Islami party of Prime Minister Gulbuddin coup by his cousin in 1973 in Hekmatyar, the embattled presiDaoud.

Daoud himself was overthrown and executed in 1978. dent's rival.

Severral MiG jet fighters and

Few Afghans expect Zahir three helicopters controlled by regarded by monatrch but he is staged a fly-past on Mestiri's arrime people, particu- val.

larly in his family's home town of The city has been peaceful since Kandahar, as a possible interim fierce fighting last year.

figurehead. Shops also displayed "Kandahar has a special responpictures of him on Sunday. sibility as a builder of peace," Mes-

Hundreds of Zahir Shah suppor- tiri told a meeting at Governor Gul ters held a noisy demonstration in Agha's office.

Quetta onsaturday.
Agha called for the convening of a traditional loya jirga, or grand council, of tribal representatives to decide Afghanistan's future.

Mestiri, due to visit the eastern border town of Khost on Thursday, is canvassing the views of Afghans on how the United Nations can help end the fighting that has caused more than 11,000 deaths in two years.-Reuter

DAWN

25 APR 1994 


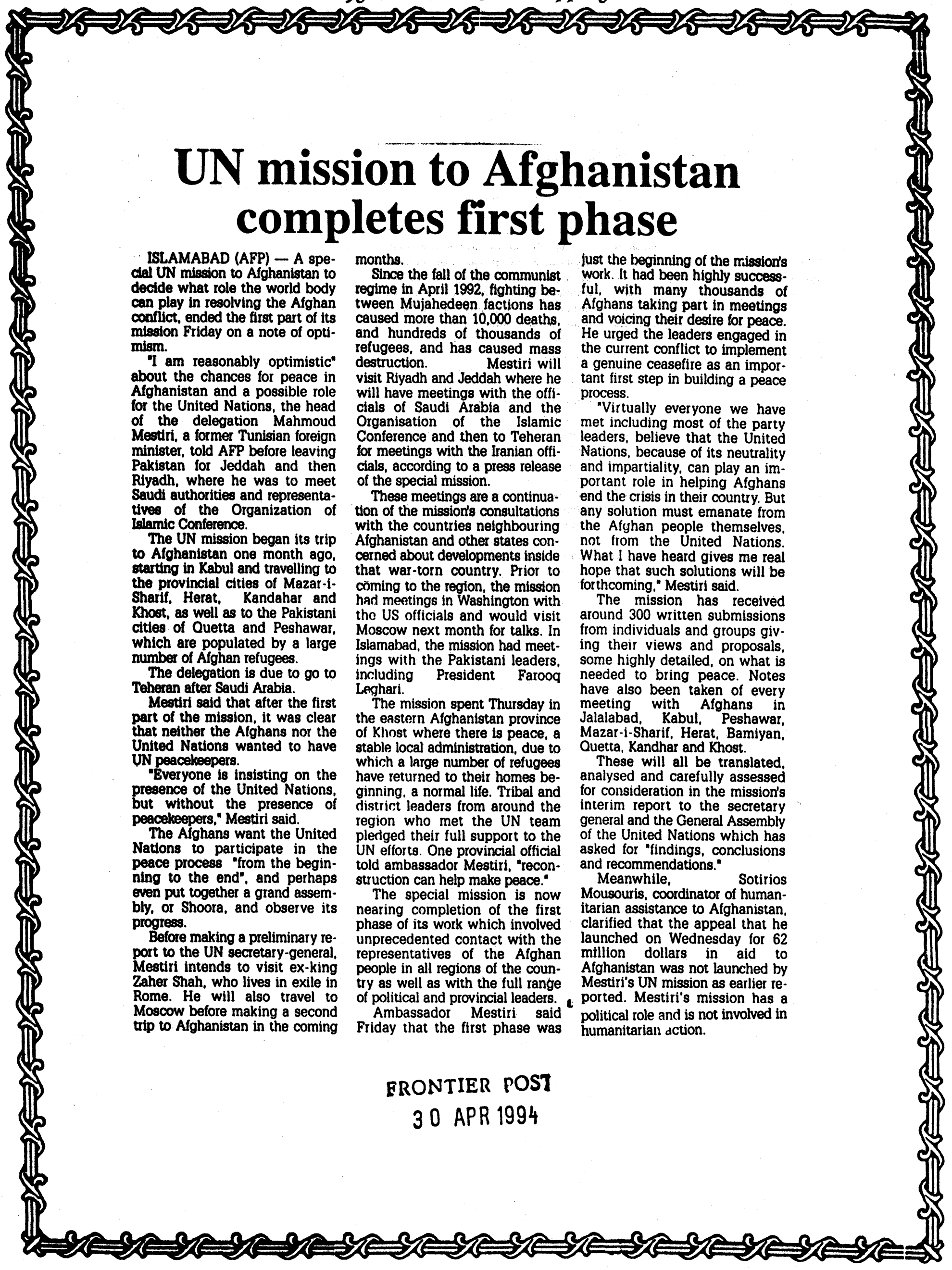




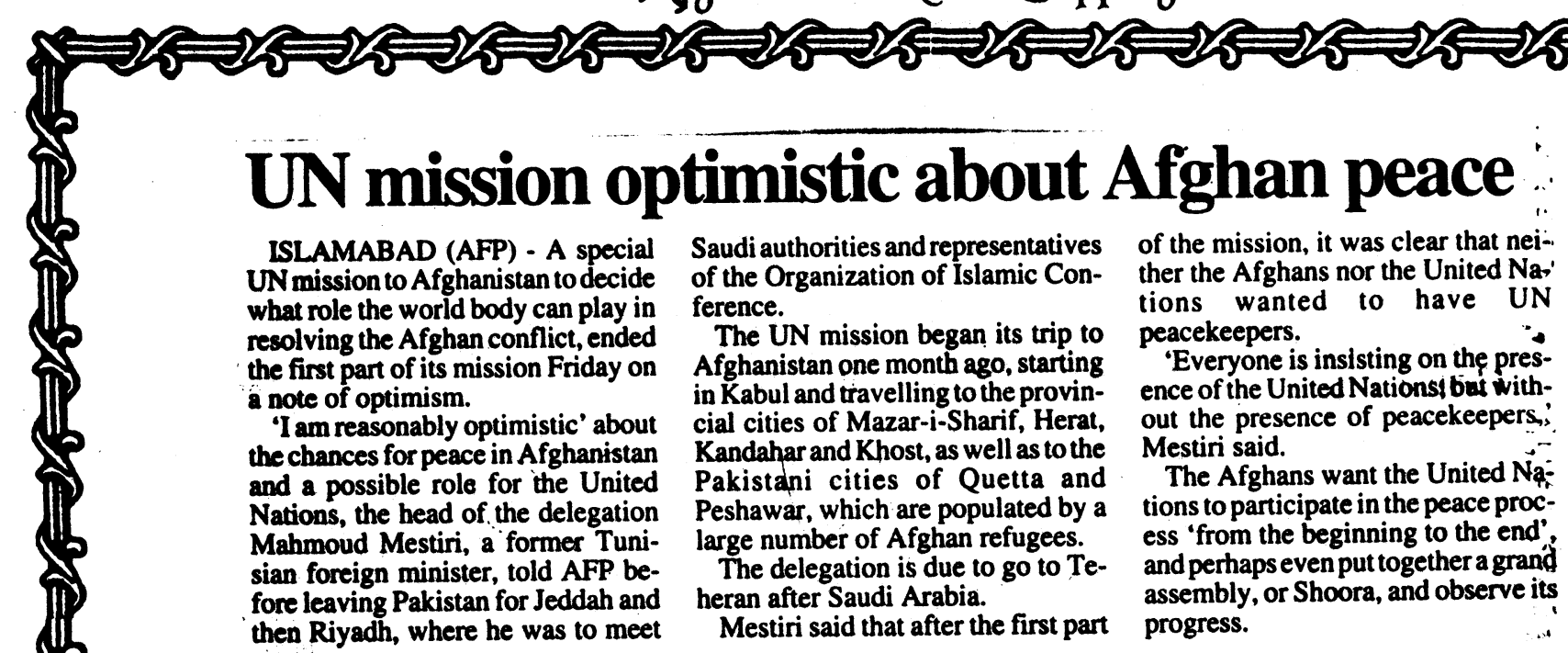

NATION

3 O APR 1994

\section{"First phase of UN mission. highly successful, says Mestiri}

\section{PPT}

ISLAMABAD: The UN special mission, headed by Ambassador Mahmoud Mestiri, Friday travels to Riyadh and Jeddah where it will have meetings with the government of Saudi Arabia and the Organisation of the Islamic Conference and then to Tehran for meetings with the government of Iran.

These meeting are a continuation of the mission's work consulting with the countries neighbouring Afghanistan and other states concerned about developments inside Afghanistan. Prior to coming to the region, the mission had meetings in Washington with the United States government and next month will visit Moscow for consultations with the government of the Russian. Fed; eration. In Islamabad, the mission had meetings with the government and with President Farooq Leghari, says a press release.

The Mission spent Thursday in the eastern Afghan province of
Khost. Tribal and district leaders form around the region pledged their full support for the UN's efforts. One provincial official told Ambassador Mestiri, "Reconstruction can help make peace".

The Special Mission is now nearing completion of the first phase of its work which has involved unprecedented contact with representatives of the Afghan people in all regions of the country as well as with the full range of political and provincial leaders.

Ambassador Mestiri said Friday that the first phase was just the beginning of the mission's work. It had been highly successful, with many thousands of Afghans taking part in meetings and voicing their urgent desire for peace. He urged the leadens engaged in the current conflict to implement a genuine ceasefire as an important first step in building peace process.

"Virtually everyone we have met, including most of the party leaders, believe that the United Nations, be- cause of its neutrality and impartiality, can play an important role in helping Afghans end the crisis in their country. But any solution must emanate from the Afghan people themselves, not from the United $\mathrm{Na}$ tions. What I have heard gives me real hope that such solutions will be forthcoming," Ambassador Mestiri said.

The Mission has received around 300 written submissions from individuals and groups giving their views and proposals, some highly detailed, on what is needed to bring peace. As well, notes have been taken of every meeting with Afghans in Jalalabad, Kabul, Peshawar, Mazar-e-Sharif, Herat, Bamiyan, Quetta. Kandahar and Khost.

These will all be translated, analysed and carefully assessed for consideration in the mission's interim report to the Secretary-General and the General Assembly of the United Nations, which has asked for "findings, conclusions and recommendations".

\section{THE NEWS INTERNATIONAL}




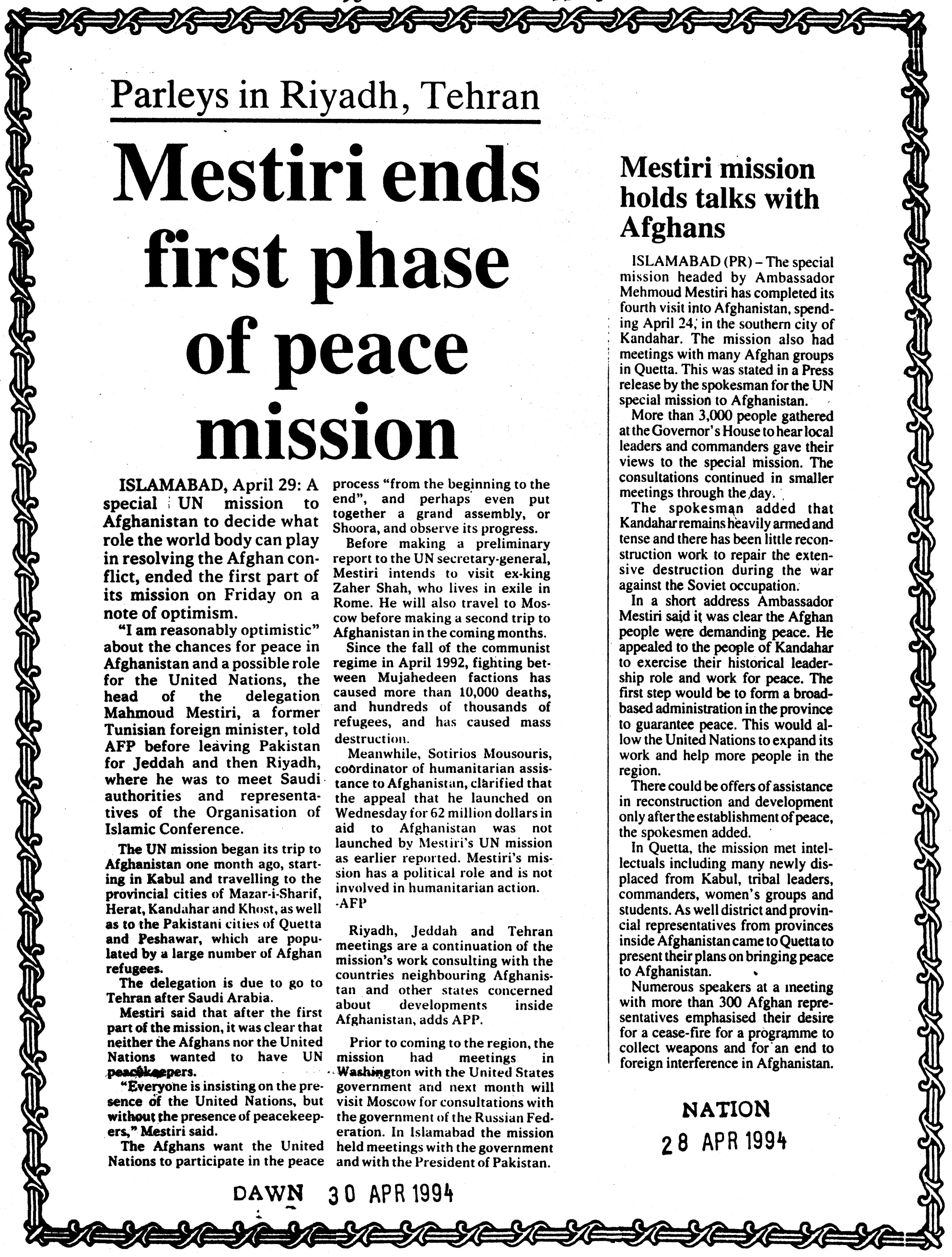




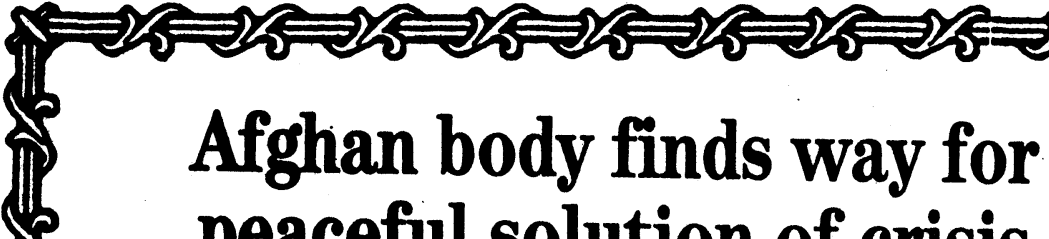 peaceful solution of crisis}

\section{Dreen Report}

PESHAWAR: The National Reconciliation Association of Afghanistan has presented a plan which it believes would pave the way for the peaceful solution of the Afghan crisis.

The plan, a press release of the associntion says, was to form a neutral interim government for two years which would hold elections in the country to have an elected set up in Afghanistan.

The first step to this effect, it says, was to bring a leadership Shura to the fore comprising 10 experienced and impartial personalities under the supervision to be approved by the Mujahideen parties.

It would also include a nominee of each party from the comman- ders, heads of the military Shura, Qaza Shura and the heads of the provincial governments.

The leadership Shura it said would appoint the new prime minister and the ministers for an interim period will appoint members of the military Shura and explore the ways and means to effectively run the affairs.

It would introduce new military and civil laws for the country and would make efforts to collect the heavy weaponry from the armed groups. The military Shura would work for the formation of a national army for the country for which every party would be required to appoint one commander to the Shura. The Qaza Shura would work for the introduction of Islamic laws in Afghanistan.

\section{IHE NEWS INTERNATIONAD}

\section{APR 1994}

\section{NATION}

\section{APR 1994}

\section{Warring factions accused of sabotaging UN initiatives}

\section{From Our Correspondent}

PESHAWAR - The emergency meeting of United National Islamic Front of Afghanistan, while expressing its concern over the fierce and horrible fighting among the Afghan factions in Kabul, alleged that both parties are once again struggling to sabotage the peace initiatives of the UN's. The meeting was held at Peshawar on Friday and was attended by a number of known leaders of the Front and their like minded people from other parties. The meeting discussed in depth the dual standard of the leaders of warring Afghan factions who are busy in fighting against each others for power. He deplored that the warring leaders declare a brief truce of ceasefire but on the very next day morning, they initiated fighting.

The meeting resolved that those, who are fighting inside Kabul for power, have lost confidence of the masses and they didn't want to allow the majority of Afghans to decide their future. The leaders of the warring factions are not representing majority of Afghans. The meeting levelled serious allegations again the warring Afghan factions for continuing fighting in Kabul and alleged that once again both the rivals have joined hands for sabotaging the peace initiatives. It reminded that after willingness of former President $\mathrm{Dr}$ Najibullah, these hard liners have sabotaged the United Nations peace plan under a well-planned conspiracy. Once against these hard liners are following the tactics and are struggling to prevent the United Nations peace delegation to visit Kabul and other parts of Afghanistan.

Through a resolution. the meeting urged the warring Afghan factions to realise thei: mistakes and stop fighting with immediately. The leaders and policy makers of the warring factions were urged to let the United Nations peace delegation to visit Kabul and allow the silent majority of Afghanistan to resolve the conflict through their own traditional and historical ways. The Afghalis, from every sphere of life, were asked to build up their pressure against the warring factions and force them to revise their negative policies.

Through an other resolution, the Front leaders in their meeting, recalled the Jehadic leaders that Afghans have rendered tremendous sacrifices for their right of self-determination. The United Nations, in all of its resolutions, also favoured the rights of the Afghans, therefore, the warring factions need to let the Afghans to utilise their right of selfdetermination. 
From Our Correspondent

PESHAWAR - Deputy Chief of the Afghanistan the Sulahi Mubaarizin, Shan Bacha while accusing the Jehadic forces of vilifying "Loya Jirga" has asked United Nations special peace envoy Mahmud Mestiri, to make efforts for the formation of such a government which could guarantee the representation and rights of all Afghans.

Shan Bacha addressing a Press conference here on Monday said that it was a golden opportunity for former Afghan king Zahir Shah to come and get the scattered Afghans assembled at one platform. "If Zahir Shah can play a positive role. It would be good not only for the war torn Afghanistan but for Zahir Shah as well". Shan Bacha further added that known Afghan leaders including Gulbadin Hikmatyar, Rabbani, Ahmad Shah Masud and persons like Zahir Shah were unaware of the miseries of Afghans as all of them were interested in power grabbing and nothing else. Narrating the story of their miseries, Shan Bacha said that Afghan women were being maltreated on Pak-Afghan border and both the Afghan Mujahideen and Pakistanis on both sides of the border were busy in looting the Afghans. He disclosed that an Afghan had to pay Rs 300 to 500 for getting the border crossed. He also informed that recently the light skirmishes on border led to the death of three Afghan minors.

Shan Bacha while expressing hope that United Nations peace envoy Mahmud Mestiri would struggle to seek an acceptable solution to the problem said that prior to any decision the parleys of Benon Sevan be kept in mind".

In case the wellbeing of the Afghan nation was ignored, as previously these talks too would prove to be fruitless. Shan Bacha appealed to Mahmud Mestiri to take concrete steps for the restoration of peace in Afghanistan as the war-stricken Afghan nation could not afford further destruction. He also asked Mahmud Mestiri to help stop the interference of foreign hands, working there for personal gains.

Shan Bacha while expressing concern over the disturbance on PakAfghan border appealed to the Premier Benazir Bhutto to look into the irregularities of Pakistani militiamen and also take notice of the maltreatment with Afghan women.

\section{Afghan leader flays Hekmatyar and Rabbani}

\section{Bureau Report}

PESHAWAR, April 4: The Deputy Chief of the Afghanistan Sulahi Mubaarizin (ASM) (Inter. mediary group), Mr Shah Badsha, has criticised the Aighan Premier Gulbadin Hekmatyar and President Rabbani holding then responsible for the on-going war in Afghanistan.

Addressing a Press conference here on Monday, he called upon the world community to intervene in Afghanistan and take appropriate measures to stop arms supply to the warring factions who were protecting the vested interests of some hidden elements, he alleged.

He said that Gulbadin and Rab. bani were opposing the Loya Jirga (the Concil of Elders) in their own interests as they did not want to settle the Afghan issue.

He was of the view that only a consensus Loya Jirga could bring peace in the war torn Afghanistan adding that without the participa. tion of Afghans the purpose of Loya Jirga could not be achieved as the same would not be acceptable to them.

Appreciating the efforts of UNO's Secretary-General's special envoy, Mr Mahmoud Mestiri, he expressed hope that he (Mestiri) would reconcile Afghan groups and would ensure peace and unity in Afghanistan. He asked him to sort sut a peace plan ensuring the security and integrity of Afghans as well as the establishment of a con. iensus government.

\section{DAWN \\ O5 APR 1994}


Bureau Report

PESHAWAR, April 9: The resentatives of Afghan MujahiAfghanistan East Zone Islamic deen factions, that in the prevailCouncil and a representative dele. ing situation, when all the peace gation of the Afghan Mujahideen attempts, have been failed, it was from south western Afghan pro- the duty of the Afghan nation, vinces have unanimously decided especialy Afghan intellectuals, to launch joint efforts to search out Ulema, tribal elders and political a permanent peace formula to stop leaders to come out and play their the ongoing bloodshed and estab. role in this critical situation, in lish a neutral central government which even the national integrity in Afghanistan.

According to Peshawar based Afghan sources, a delegation of Afghan Mujahideen and tribal elders consisting of the sourh western provinces of Herat, Nemrose, Ghazni, Faras and Orgzan had I arrived Jalalabad the capital of Nangrahar province last Tuesday, in a bid to sort-out a jjjjoint strategy to search-out a permanent solution to the ongoing Afghan conflict.

The delegation remained in Jalalabad for last two days and held several meetings with the leaders of different Mujahideen factions and members of AEZIC including Nangarhar governor $\mathrm{Haji}$ Abdul Qadeer Khan and discussed in details the arrangements of their peace seminars, which had been announced by both of them in Jalalabad and Herat with inten. tions to search and give a final shape to a joint formula to find ways and means for its imposition.

It is also pertinent to note that due to understanding between the Pushto and Persian speaking dominated areas had broken the rumours being launched by some quarters that announcement of two separate seminars in two different ethnic places would further increase the gap between the war. ring factions, sources added.

Both the parties had reached con. clusion after detailed talks, held at the office of Nangarhar governor and was attended by all the rep. was also at the verge of collapse to steer the country out of the ongoing remedy to the crises.

They insisted that they had to play their role. so that sacrifices given by the Aighan martyrs against foreign aggression were not wasted and the ideology could be safeguarded.

IRANIAN ENVOY MEETS MUJADDEDI: Special representatives of the Ministry of Foreign

Affairs of the Islamic Republic of Iran, Mr Ibrahim Tahirian met the National Liberation Front chief and a former president of Afghanis tan, Prof.Sebghatullah Mujaddedi, at the latter's residence here on Saturday and exchanged views with him on current situation in the war-torn country.

According to an Iranian consu late Press release, $\mathbf{M r}$ Tehirian apprised the Afghan leader about the peace efforts that his country had so far made to defuse the situa. tion.

Mujaddedi was also brifed about the meetings that the Iranian rep resentatives so far had held with different Afghan leaders and group leaders in order to find out ways to bring an end to the ongoing confrontation.

Sebghatullah Mujaddedi, while paying his gratitude and appreciation for the peace efforts of Iran. expressed the desire of continuation of these efforts to which both sides agreed. bloodshed and find a permanent

\section{Afghan professors want neutral govt}

\section{Bureau Report}

PESHAWAR: The Association of Professors of the Universities of Afghanistan (APUA) has called upon the United Nations to convene the Loya Jirga for forming a non-partisan and broad-based government representing various segments of the Afghan society.

In this connection APUA believes that the Afghanistan's prime minister and the president should resign and transfer power to a neutral body to do spadework for convening the Loya Jirga in consultation with Afghan factions and social and political figures in and outside Afghanistan

The second option for a viable political solution, APUA believes, is the establishment of a broad-based interim government through intra. Afghan dialogue provided that im. portant portfolios should not be al. lotted to the leaders of the factions or to their nominees. Such a government should have a national army and security forces at its command to be formed with $\mathrm{UN}$ assistance.

\section{No new peace proposals: Dostum}

ISLAMABAD: Mehmoud Mestiri head of the UN peace mission to Afghanistan, on Tuesday visited Mazar-e-Sharif, a stronghold of General Abdul Rashid Dostum.

According to a Voice of America report, Mr Mestiri held a brief formal meeting with General Dostum in which he said he was expecting a countrywide ceasefire.

A BBC report said that after the talks with the delegation Gen Dostum said he has offered no fresh proposal for restoring peace in Afghanistan. He told newsmen at the airforce ground that he wants peace but President Professor Burhanuddin Rabbani should first step down.

Mr Mestiri also hèld long meetings with teachers, doctors, women's groups and the governors of the northern provinces.

Mr Mestiri was given a warm welcome on his arrival. Rose petals were showered on the UN motor convoy. Thousands of people stood on both sides of the road, carrying placards demanding peace and President Rabbani's resignation.-APP 


\section{Afghanistan
peace formula proposed}

\section{Bureau Report}

PESHAWAR, April 16: The country.

Afghan peace mission, headed by This nominated Shoora will also Commander Maulvi Jalaluddin prepare an interim constitution for Haqgani, has announced its prop. the country which would serve the osals for the restoration of peace in purpose of rule of law during the the war-torn country, after holding interim period.

a series of talks with the leaders of The Afghan sources have indiwarring factions that took about cated that the Shoora proposals two months.

According to these proposals, the President and Prime Minister would not be appointed from the warring factions and would be drawn from the neutral groups.

The proposed formula envisages formation of a broad-based Islami Shoora in which, besides represen tatives from all the Mujahideen organisations, some 100 delegates would be nominated from amongst the intellectuals, Ulema etc., now living in Europe and elsewhere.

This Shoora will elect head of the state and head of the governmen for a specific period.

have been prepared after an inde pth study of the situation and in the light of peace mission's negotiations with the various sections of Afghan leadership and it is hoped that these will be approved by them.

The Afghan peace mission, had been formed soon after the begin. ning of the ongoing factional war in and around Kabul. Since then Maulvi Jalaluddin Haqqani led the mission comprising mostly field commanders from various Afghan organisations and held a series of meetings with Prof Rabbani, Eng Hekmatyar and Masood, Prof

The Shoora will act as a supreme Sayyaf and other leaders. The advisory body till fresh elections peace mission enjoyed blessings of for a parliament are held in the Prime Minister Hekmatyar.

\section{DAWN 17 APR 1994}

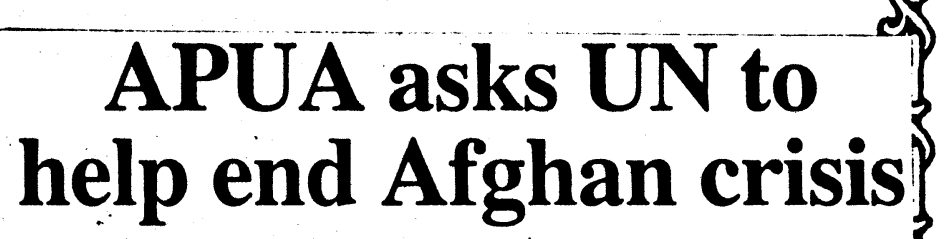

F.P. Report

The association of Professors of the Universities of Afghan (APUA) has asked United Nations to induce regional powers to put an end to interference in Afghanistan and instead extend unreserved cooperation to UN peace process.

APUA, which was established in 1989 by a number of former Afghan professors, now represents more than 200 professors living in Peshawar, has in a letter. addressed to UN, stated that the Afghan people attached great importance to the renewed interest of the world body to promote a political settlement to the lingering Afghan conflict resulting in mass suffering of the Afghans due to continued foreign interference in the internal affairs of Afghanistan.

It was stated that there are time honoured traditions whereby Afghans have always resolve their problem at national level based on national consensus. In this respect, Loya Jirga being a manifestation of peoples' will can be convened under the auspices of the UN to a non-partisan and broadbased government representing various segments of Afghan society.

It was added that APUA strongly believed that the permanent ceasefire, simultaneous res. ignations of both the president and prime minister and transfer of 1 power to a neutral body of highly competent and well-known Afghans to war for convening Loya Jirga in consultation with Afghan factions, social and political figures within and outside Afghanistan.

About the second option it was stated that a broad based interim government be established through intra Afghan dialogue provided that portfolios relating to the president, prime minister, defence, foreign, interior and finance ministers should not be allotted to the leaders of the factions or to their nominees. Such a government should have a national army and security forces at its com. mand to be formed with the UN assistance. It was added that the resolution of the ongoing conflict solely depends on the UN peace making efforts to be backed up by the international society and par. ticularly by the United States in the first place.

FRONTIER POST

\section{APR 1994}




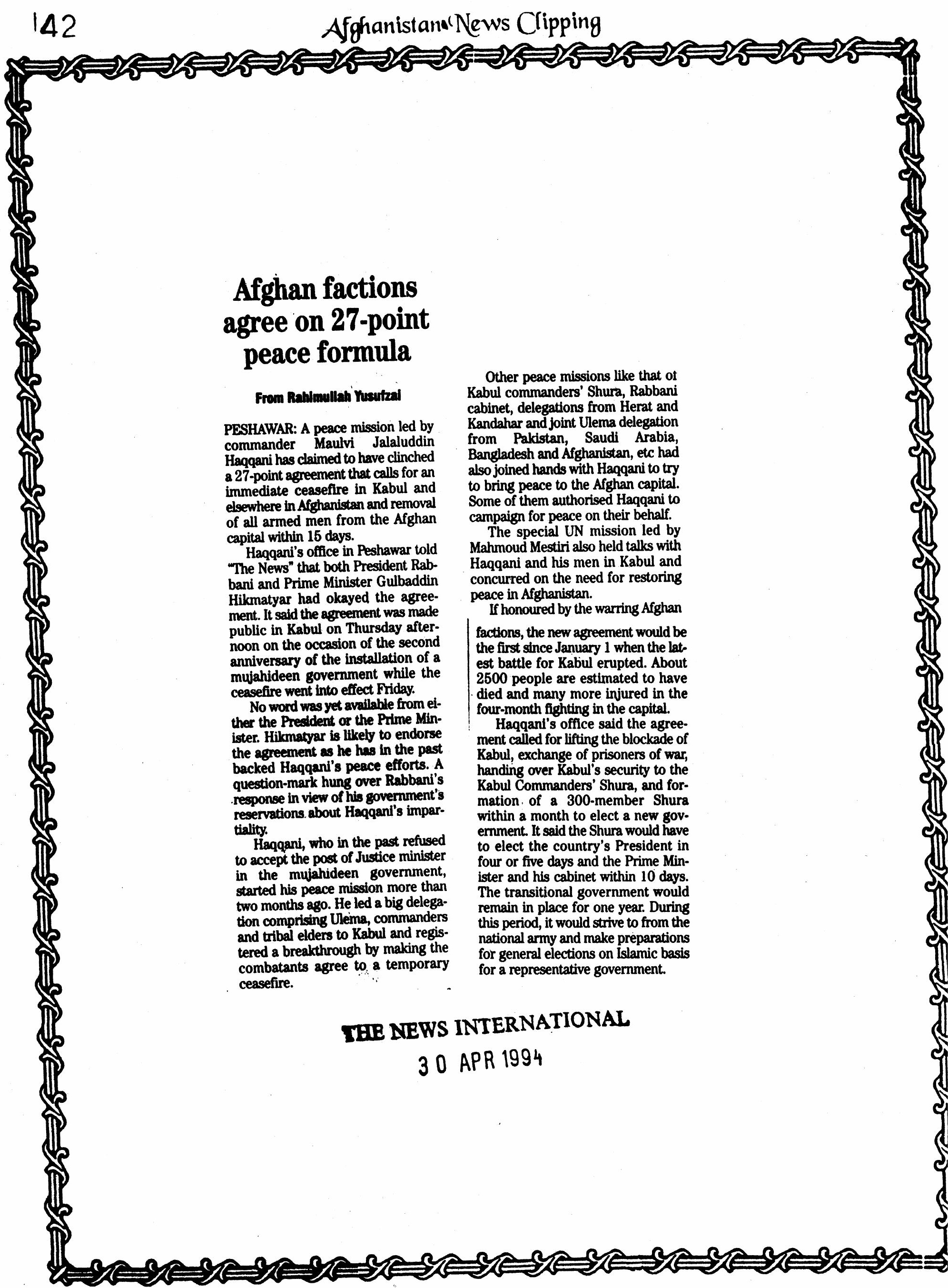




\section{Zahir Shah option resurfaces} in search for Afghan peace

\section{From Rahimullah Yusufzal}

PESHAWAR: The Zahir Shah option is once again being considered as a possible solution to the Afghan imbroglio in view of the failure of all previous accords and power-sharing agreements in Afghanistan.

Reports from Rome, Italy where - the ex-king has lived in exile since 1973 , said Zahir Shah is an unusually busy man these days. Diplomats from Western and other countries and Afghan notables often visit his residence to seek his audience and discuss measures that could restore peace in war-torn Afghanistan.

Nabi Misdaq, an Afghan journalist who met Zahir Shah in Rome a few days ago, told "The News" that the 79-year old former king was keeping fit and looked much

younger than his age. "He appears a sprightly man whose age couldn't be more than $60,{ }^{n}$ he remarked. In comparison, he said the ex-king's son-in-law, Gen Abdul Wali, who wields great influence over him, looked older than him.

Zahir Shah came to live in Rome when his cousin Sardar Daoud deposed him in a bloodless coup and declared the end of Afghanistan's monarchy. Daoud himself was overthrown and killed along with several of his family members in a military coup d'etat sponsored by the leftist People's Democratic Party of Afghanistan on April 27, 1978.

Zahir Shah's name has often figured as an acceptable head of an interim Afghan government that could oversee the restoration of peace, building of a national army

THE NEWS INTERNATIONAL

O6 APR 1994

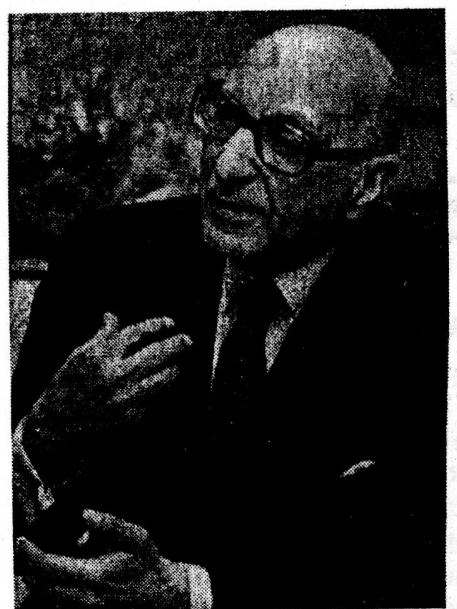

and other institutions and holding of general elections. However, Islamist groups like President Rabbani's Jamiat-i-Islami, Prime Minister Gulbuddin Hekmatyar's Hezb-i-Islami, Prof Sayyaf's Ittehadi-Islami and Maulvi Yunis Khalis' Hezb-i-Islami have consistently opposed his return to power and accused him of paving the way for communist rule in Afghanistan.

Though nobody has been able to judge public opinion in present-day Afghanistan, ex-king supporters often claim that he remains the most popular Afghan leader, acceptable to all ethnic, linguistic and religious groups. They cite a survey conducted in Afghan refugee camps in Pakistan by the late Afghan scholar Syed Bahauddin Majrouh's Afghan Information Cen-

tre in July 1987 in which an overwhelming majority named Zahir Shah as the most suitable to provide political leadership to the Afghan people.

Among men, 1,433 (71.65 per cent) chose Zahir Shah compared to 1.75 per cent for all leading mujahideen commanders like Ahmad Shah Masood, Ustad Farid, Abdul Haq and Haqqani put together and only 0.45 per cent for the seven mujahideen leaders including Rabbani, Hekmatyar, Pir Gillani, Nabi Mohammadi, Khalis, Sayyaf and Mojadeddi. Among the 155 Afghan women interviewed, 50.32 per cent favoured Zahir Shah, 5.16 per cent Rabbani, 3.87 per cent Gillani, 1.58 per cent Hekmatyar, 1.29 per cent Nabi Mohammadi, and 1.29 per cent Mojadeddi.

The survey's outcome was surprising. Mujahideen leaders denounced the survey and termed it unscientific, biased and misleading. Majrouh, who was assassinated in Peshawar some time later by unknown gunmen, was accused of manipulating the survey's findings to drum up support for the former monarch.

Zahir Shah, who was never able to carry favour with the Pakistan government as long as Gen Ziaul Haq was in power, is hopeful of getting Islamabad's nod now that the PPP is in power. Federal Interior Minister Maj Gen (Retd) Naseerullah Babar, PPP's pointsman on Afghan affairs, has already named Zahir Shah as the only viable alternative to head a transitional government in Afghanistan.

However, Afghan sources said the ex-king is keen on winning the support of Western powers led by the US as well as of Russia before making up his mind whether or not to play a role in forming a broadbased government in Afghanistan. $\mathrm{He}$ is seeking guarantees of their support to be channelled through the UN not only to ensure his personal security but also sustain his government in power in the face of threats by some of the radical Islamist elements.

In his recent statements, the former Afghan monarch has expressed his readiness to help restore peace and rebuild his homeland provided the Afghan people ask him to do so. In practice, that means an opportune time which many Afghans believe has arrived now that the UN has revived its interest in resolving the Afghan conflict. 


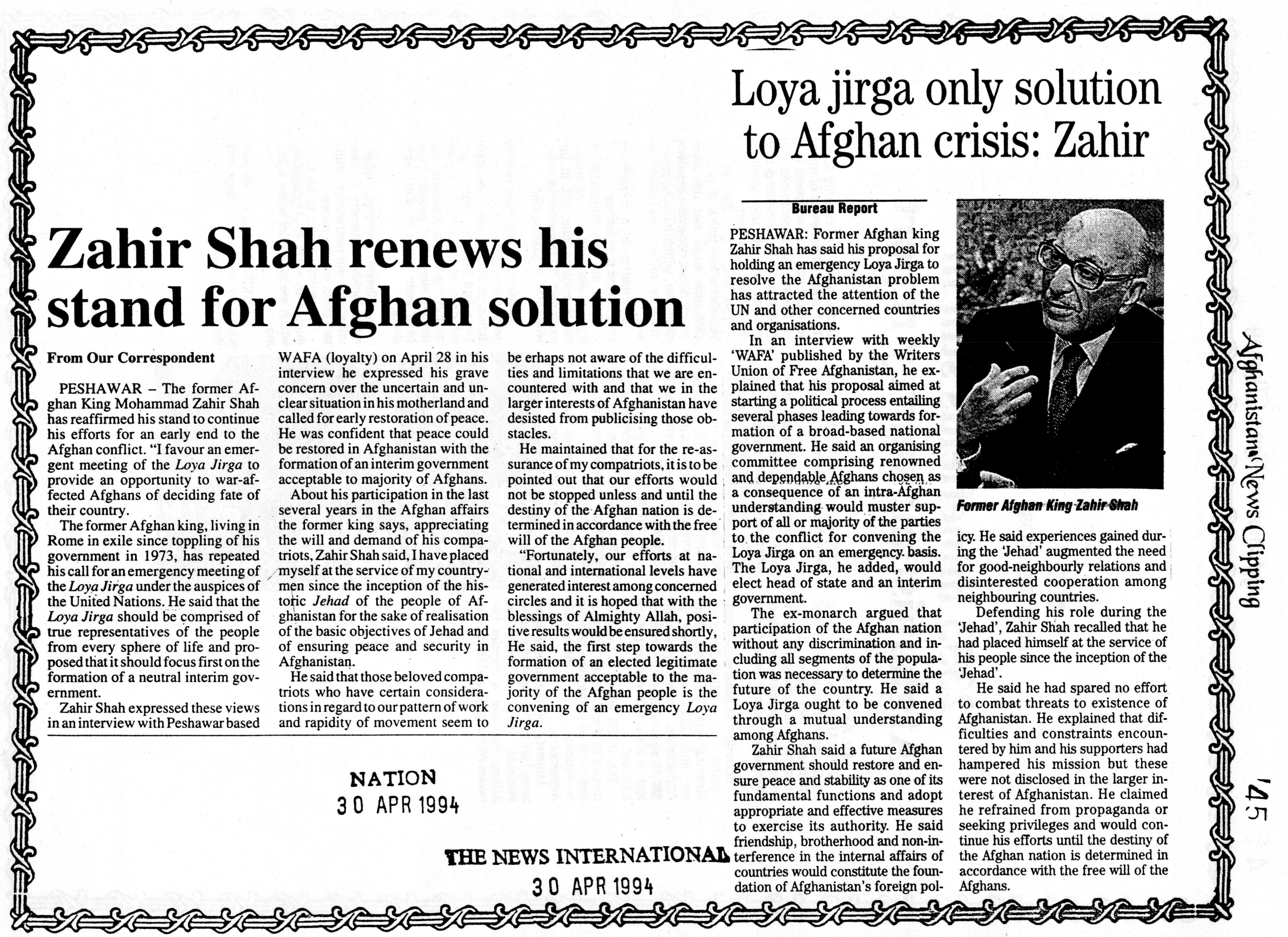




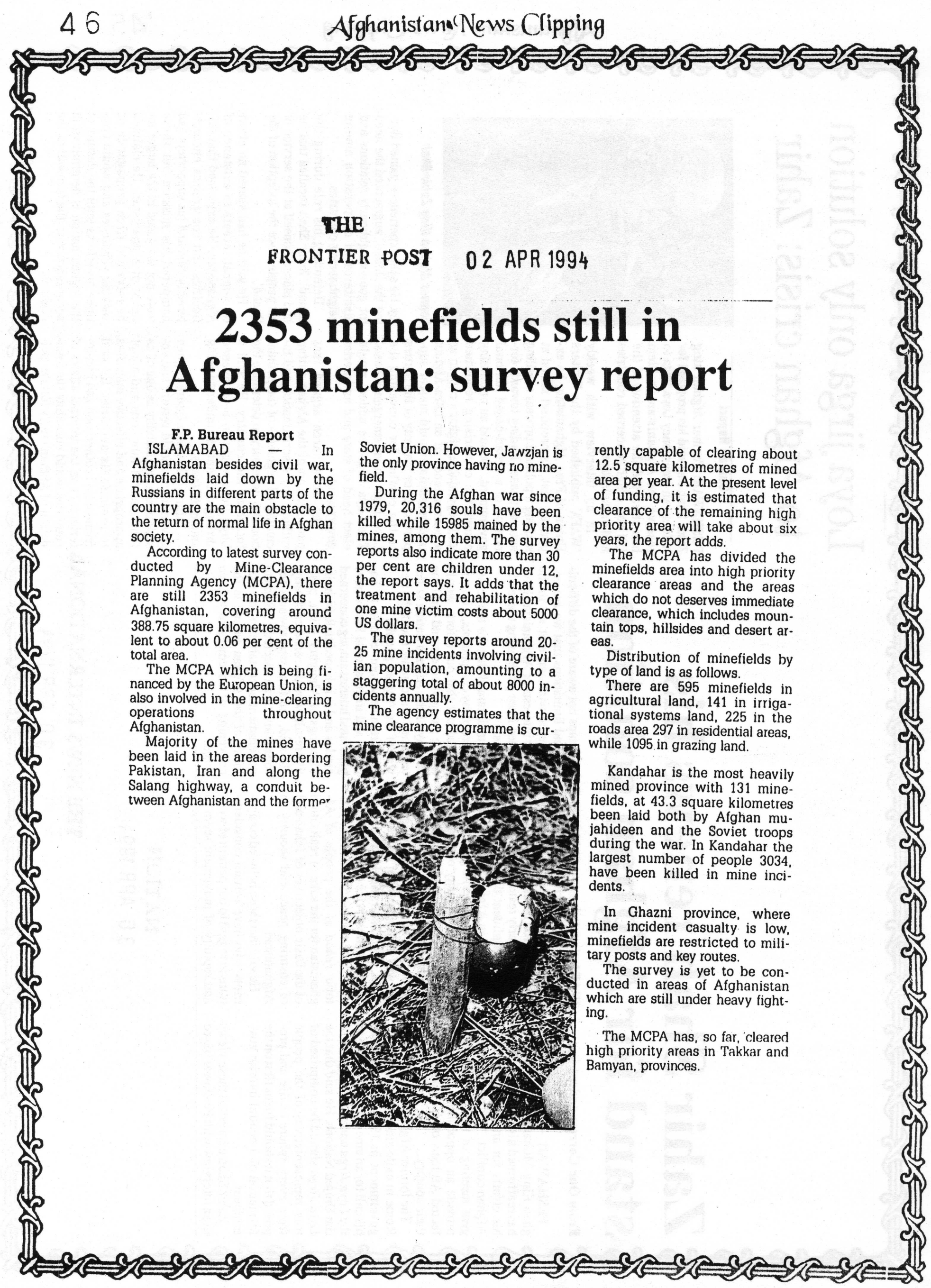




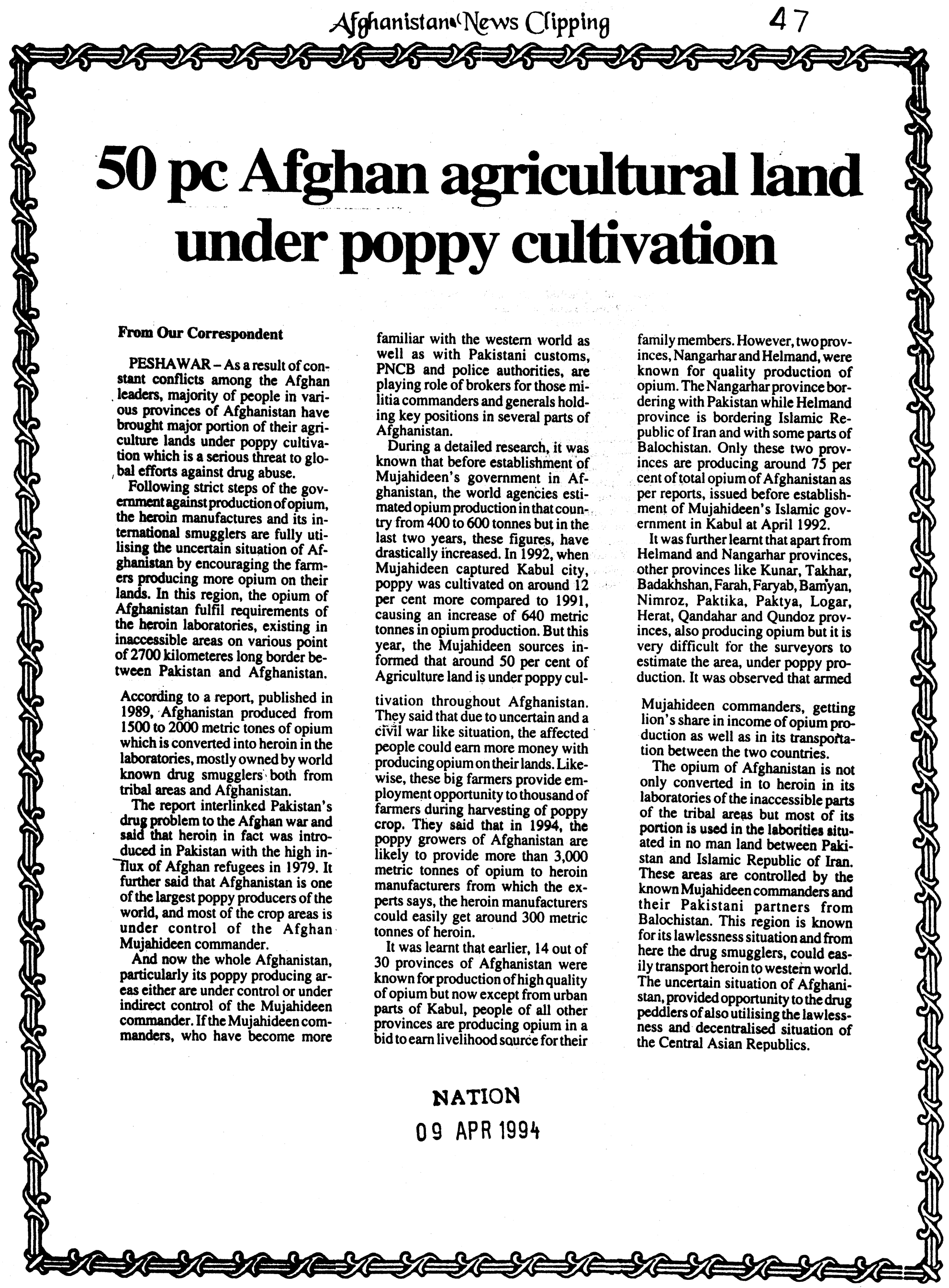




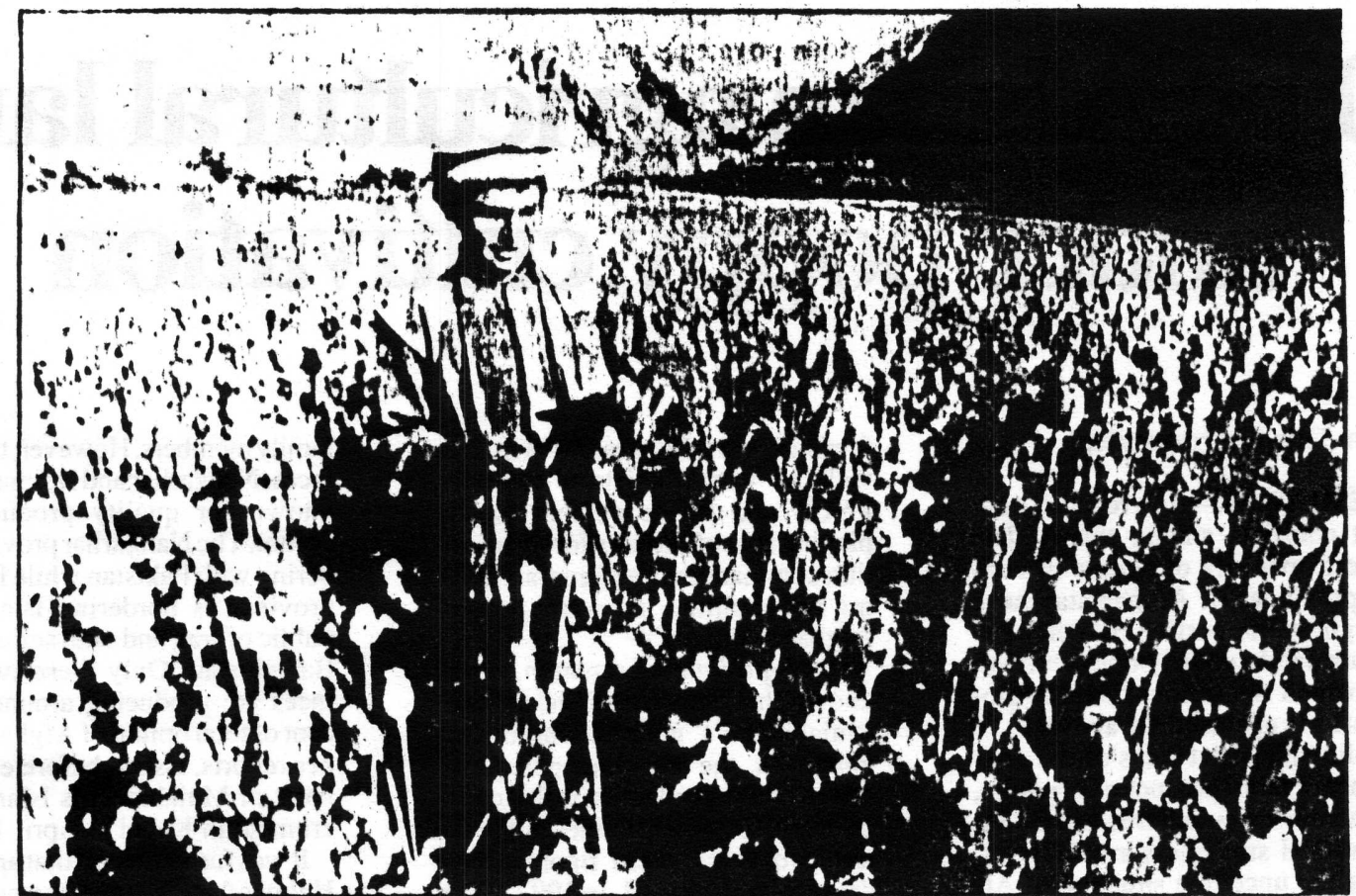

\section{Main heroin peddling centres in Afghanistan}

Rabat: Zaranj and Chughaki are the three main centres in Afghanistan from where heroin is smuggled abroad, writes Hafeeza Khanum in April issue of Diplomat, an English monthly published from Peshawar. Zaranj is the capital of Nimroz province where heroin factories are working and the product is exported to Zabal and Zahidan in Iran. From Iran the product is onwards smuggled into Turkey.

In Nimroz province the most notorious smugglers are Haji Abdul Qayyum Baloch Rukhshani and Karim son of Haji Gumee Saswaali. In Chughaki, which is a centre for opium collection from the provinces of Hilmand and Farah, the heroin produced in local factories is smuggled into Iran via the border provinces of Sufai $\mathrm{Aba}$ and Birjand. The product is also smuggled from here into Pakistan. From the Iranian border provinces the heroin is further smuggled to Mashhad and Teheran. Here the gangs are oper- ating under Fida Muhammad "̌han Bobakzai and Haji Sher Ali Gurg.

The heroin produced in Rabat, the capital of Hilmand province, is smuggled into Pakistan and the gangs operate under Haji Abdul Rehman of Hilmand and Haji Asad Barahvi of Nimroz. In Iran the gangs of heroin smugglers are connected with Khan Muhammad son of Jalal Barahvi. Mula Qalandar and Subhan, both from the province of Hirat, are known smugglers in Pakistan who are connected to the gangs operating in Afghanistan. They have an accomplice by the name of Sakhi Dost Jan in Quetta,

\section{ERONTIER POST}

15 APR 1994

For more about Drugs; pleses see page

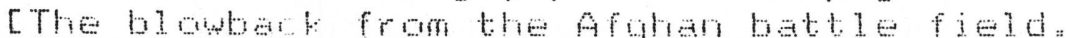




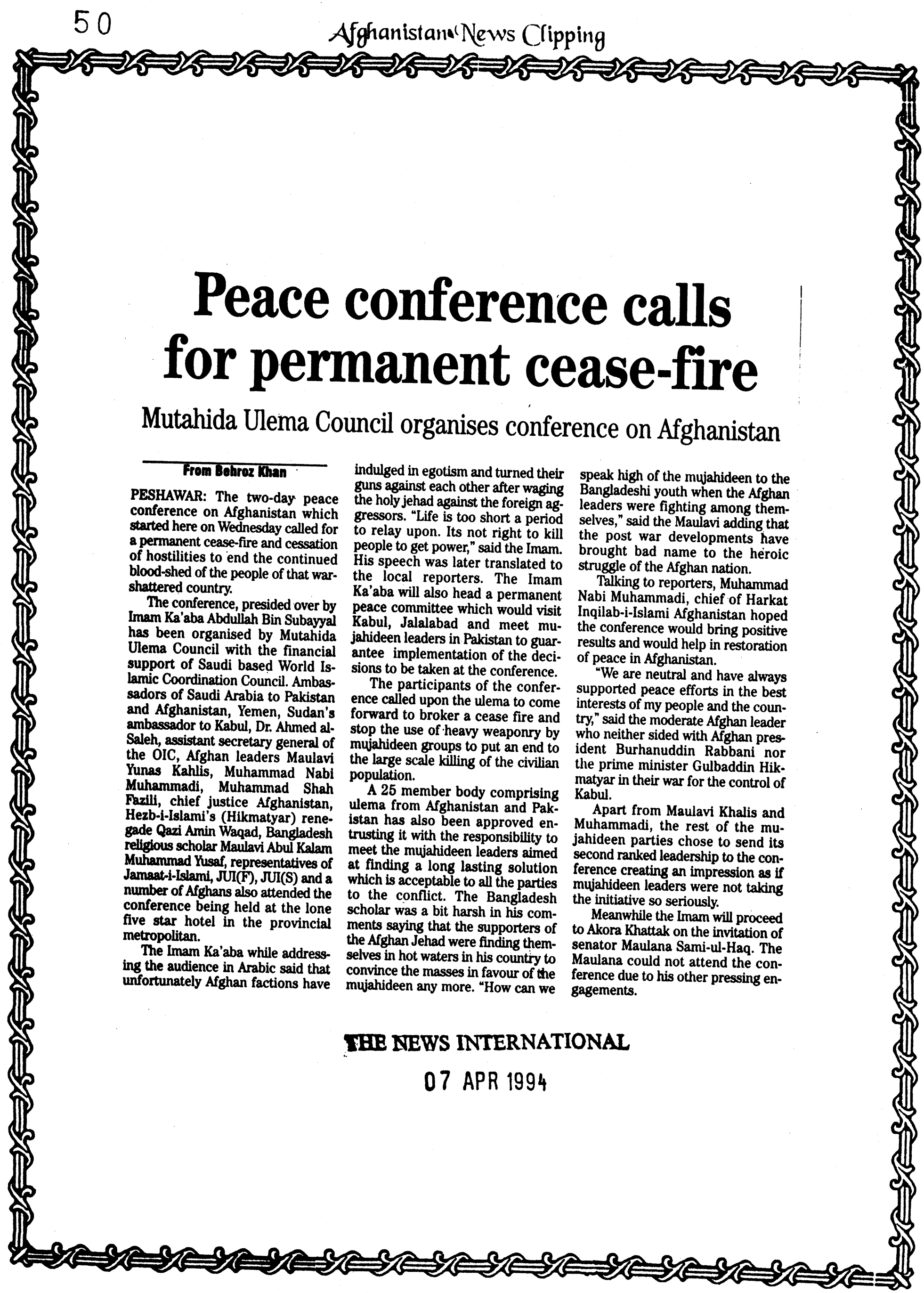




\section{Afghan issue Seminar calls on Rabbani, Hekmatyar to stop fighting}

BY AZIZULLALH MARWAT

The participants of the second international conference of Muslim scholars on Afghan Issue have appealed to King Fahd of Saudi Arabia to allow Muhammad Abdullah Subayyal, Imam-eKa'aba to lead a reconciliatory delegation to Kabul for permanent solution to the Afghan problem.

According to reports Imam Ka'aba has refused to lead the delegation to Kabul and it was said that his deputy (Naib Imam) Dr Saleh will lead the delegation and at the third stage Maulvi Muhammad Nabi Muhammadi of Harkat-e-Inqelab-e-Islami Afghanistan will take the delegation to Kabul which will be comprised the religious leaders of Pakistan, Afghanistan, Saudi Arabia and other Muslims countries.

The delegation will hold talks with Afghan leaders to bring peace and work for a strong Afghanistan. Imam-e-Ka'aba have also written a letter to the Afghan leaders for restoring peace in Afghanistan. He has appealed to the Afghan leaders to shun their differences and unite for the reconstruction of their country.

The two day conference organIsed by the Muttahida Ulema Council with the support of Islamic Coordination Council concluded with the prayers made by the Imam on Thursday afternoon. He prayed for peace and unity in the Muslim World.

Earlier, three resolutions were unanimously passed in the conference. In the first resolution which was accepted by the participants it was said that a letter would immediately be sent to the President Burhanuddin Rabbani and Prime Minister Gulbaddin Hekmatyar asking them to hold permanent ceasefire in Afghanistan for the sake of Islam and Muslim Ummah.

It was decided that a reconcillatory delegation comprised the religious leaders of Pakistan, Afghanistan. Saudi Arabia and other Muslim countries

will visit Kabul and hold meeting with President Burhanuddin Rabbani and Prime Minister Gulbaddin Hikmatyar for resolving their differences. The delegation will also take the decision on a plan with the recom. mendation of all the Afghan lead. ers which will be acceptable to all warring groups and will pave the way for peace in Afghanistan. Third resolution was that secretariat will be established in Peshawar or Jalalabad to implement the above recommendations and decisions.

Three committees were also constituted i.e. finance committee, mediatory committee, and supervisory committee which will supervise the situation after the ceasefire.

Leaders of six Afghan parties Ustad Muhammad Yasir of Ittehad-e-Islami Afghanistan, Hashmi of Harkat-e-Inqelab-eIslami, Sarfaraz of Hizb-e-Islami Afghanistan (Hikmatyar). Ilhamuddin of Hizb-e-Islami (Khalis), Maulvi Muhammad Ismail of Jamiat-e-Islami and Rais Tahir Khan of Mahaz-e-Mili will participate in the delegation. While the invitation to the religious leaders of Pakistan was open where as some prominent leaders were mentioned as, Maulana Fazlur Rahman, Maulana Samiul Haq, Abdur Rahim Chitrali MNA, Maulana Gohar Rahman, Maulana Inayatur Rahman, Maulana Yousaf Qureshi, Maulana Usmani, and Maulana Hasan Jan.

The members from other Islamic countries are Dr Abdullah Zahid ex-vice chancellor, Madina University, Dr Abdullah Musleh, Dr Abu Abdur Rahman, Dr Ibrahim Bakar, assistant general secretary OIC, and Abdullah Al Aqeel, assistant general secretary of Islamic Coordination Council.

During the working session the participants discussed various aspects of the Afghan issue. Maulvi Muhammad Nabi Muhammadi of Harkat-i-Inqilab-i-Islami and Maulvi Muhammad Younas Khalis, who chaired the sessions were of the view that in case Imam-e-Ka'aba had not been able to visit Kabul then a sub committee comprising only its members will go to Kabul so as to prepare grounds for the leaders who will arrive in Kabul to reconcile the situation. Muhammadi said "we will go later when the sub-com- mittee will give a green signal"

The other participants said that it will be disgraceful if the leader of the Afghan political parties especially Burhanuddin Rabbani and Gulbaddin Hekmatyar turned down the appeal of Imam-e-Ka'aba. They said "we will exert more pressure on the leaders to arrive at a decision in the best interest of Afghanistan and its people".

\section{Ulema moot on Afghanistan from 6th \\ F.P. Bureau Report}

ISLAMABAD - Muttahida Ulema Council of Pakistan is holding its 2nd international conference of Muslim scholars and ulema in Peshawar from 6 to 7 April. to discuss ways and means of reconciliation between the waring factions of Mujahideen in Afghanistan.

The conference will be held un. der the patronage of Imam of Kabah. Shaikh Muhammad Bin Abdullah Assubayyal.

Besides the ulema of Pakistan and Afghanistan, the occasion will assemble a big number of eminent Muslim ulema and scholars from all over the world, which includes Dr. Abdullah Zayed, Dr. Abdullah al-Musleh, Shaikh Abdullah al-Aqed. Dr. Ibrahim alFayaz from Saudi Arabia, Shaikh Yaseen Imam from Sudan. Maulana Abul Kalam Mohammad Tomuf from Bangladesh, Shaikh Omer Saif from Yemen and number of schalars from Central Asian Muslim republics.

ERONTIER POST O 6 APR 1994 
Afghanistan.

It was observed that majority of the delegates, particularly from Saudi Arabia and other countries were hesitant to enter Afghanistan. Imam-iKaaba Abdullah Bin Sobail later said he will consult King Fahd on this matter. In this connection, some delegates have also urged King Fahd to allow Abdullah Bin Sobail to visit Afghanistan.

The spokesman added that in case Abdullah Bin Sobail decided of not entering Afghanistan, than Harakat Islami Chief Maulvi Mohammad Nabi Mohammadi will lead the delegation.

Other members of the delegation included MaulviMohammad Younas Khalis, Abdullah Musleh and Ustad Yassar of Ittehad Islami, Hashmi of Harakat Islami, Sarfraz of Hizbe Islami (Hikmatyar), Alhamud Din of Hizbe Islami (Khalis), Ismael of Jamiat and Tahir Khan of Natinoal Islamic Front, its members.

Maulana Samiul Haq, MNA, Maulana Fazlur Rehman, MNA, Abdul Rahim Chitrali, Maulana Gohar Rehman and others will also join the scholars as members of the delegation.

The conference also formed three committees included finance, jus- tice and administrative committees which will look after the affairs of the peace delegation in Kabul.

The spokesman informed that before deciding formation of the committee, the conference on Wednesday night made an appeal for prolongation of the ceasefire in Kabul. In this connection, Haji Fareed conveyed appeal of the conference to Engineer Gulbadin Hikmatyar and Ismael Khan conveyed the said appeal to President Rabbani. He said that conference expressed the hope that both the rival leaders will honour wishes of the world level Muslim scholars and the ceasefire will remain intact till finding out an amicable settlement to the Afghan conflict.

The spokesman said that conference till Thursday noon focused on three main topics which included :1) How to implement permanent ceasefire in Afghanistan, 2) Whether the previous agreements and accords are applicable and 3) To form a tribunal for placing responsibility of the violation of agreements and bloodshed in Afghanistan on one of the Mujahideen leader. He said that the peace delegation will try to implement these decisions during visit to Afghanistan.

NATION 08 APR 1994

\section{Ulema moot urge Afghans to end fighting}

From A Correspondent

PESHAWAR, April 8: The two. day International Ulema Conference ended here on Thursday urging both President Rabbani and Prime Minister Gulbadin Hekmatyar of Afghanistan to end their power tussle in the name of Allah and Islam.

A resolution adopted at the concluding session of the conference, which was presided over by Imame-Kaabatullah, Al-Sheikh Moham. mad Abdullah ibne Subayyal, it was appealed to both Rabbani and Hekmatyar to agree to a permanent ceasefire in the name of Allah, Islam and the Muslim Ummah for settling the problems through

\section{negotiations.}

Through another resolution the conference called for constitution of a reconciliatory delegation which should visit Kabul and make efforts to defuse tension among the warring factions and to find out a solution to bring peace to Afghanistan.

The third resolution called for establishment of a permanent secretariat for the ulema's reconcilatory mission either in Peshawar or Jalalabad which should continue to work till the permanent settlement of the issue.

Meanwhile, it was also learnt that the conference has written a letter to King Fahd of Saudi Arabia to allow Imam-e-Kaaba to lead the reconciliatory delegation to Kabul to hammer out a peace settlement.

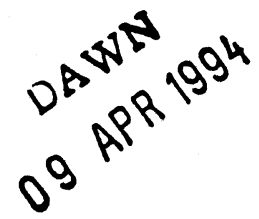




\author{
Imam Ka'aba stays away from peace convoy to Kabul
}

\section{From Bohroz Whan}

PESHAWAR: The peace delegation comprising of ulema from Pakistan, Afghanistan and Saudi Arabia is scheduled to leave for Kabul on Sunday to negotiate a new ceasefire between the warring mujahideen groups.

Maulavi Yunas Khalis, head of his own faction of Hezb-i-Islami would lead the delegation formed during the two-day peace conference organised by Pakistan based Mutahida Ulema Council at Peshawar.

The conference was attended and presided over by Imam Ka'aba, AlSheikh Muhammad Bin Abdullah AJSabayyal.

The Imam was expected to head the peace delegation to Kabul but he chose not to accompany the convoy and left for the Arab kingdom creating doubts about the success of the mission.

Some 25 Pakistani ulema, three Saudi religious scholars including
Sheikh Abdullah Aqeel, Sheikh Abdullah Musleh and Dr Sheikh Abdullah Zaid and a number of Afghan religious leaders are a part of the delegation. Maulana Sami-ul-Haq, head of his own faction of Jamiat Ulema-i-Islam and Maulavi Abul Kalam Muhammad Yusaf of Bangladesh have also changed their programme and would not accompany the peace mission.

The main cause of change in the schedule were the conditions put forward by the Afghan Prime Minister, Gulbaddin Hikmatyar, expressing certain reservations over the selection of the delegation members and its task. The letter sent by Hikmatyar was translated in Arabic to apprise the Imam Ka'aba of the Hezb-i-Islami point of view. Hikmatyar suggested that the ulema delegation would have to contact commander Jalaluddin Haqani, holding talks with the warring groups to broker a ceasefire and it must become a part of the peace mission started by the commander from Paktia province of Afghanistan.

The Afghan premier also pinpointed that the delegation must have members from all the Islamic countries instead of giving representation to Saudi Arabia and Pakistan only.

Hikmatyar had also convoyed to the organisers of the conference that no member either from President Rabbani or the Prime Minister or its close allies should be included in the delegation as all of them he thought were direct party to the ongoing clashes, told Haji Farid, Hezb's official spokesman at Peshawar.

It is reported that King Fahd of Saudi Arabia has faxed a message to Imam Ka'aba asking him to accompany the delegation to Kabul. The fax was, however, received an hour after the departure of the Imam.

The Pakistani ulema would leave for the Afghan capital after a meeting at Mohabat Khan mosque this morning.

\title{
Peace committee of Muslim scholars fails to visit Kabul
}

\section{From Our Correspol adent}

PESHAWAR - The : peace committee, constituted in the second international conferenci $z$ of Muslim scholars, failed to visitt Kabul to resolve the differen ces among Mujahideen leaders an d enable them to building up a concen isus for establishment of a pure Isl:amic government in Afghanistan.

The committee was icomprised on leading figures of Islar nic organisations from various c(suntries. The committee was formerd a few days ago in an internationa l conference. First Imam-i-Kaaba A Ibdullah Bin Sobail was made as hea d of the committee but he excused to visit Kabul due to unavoidable e:ngagements. Later, Afghan learter Maulvi Mohammad Nabi Mohımmadi was named as head of the c:ommittee.

However, after retur $n$ of Imam-iKaaba Abdullah Bin Scrbail, to Saudi Arabia on Friday last, the whole programme was disrupted. First the com- mittee announced to visit Afghanistan on Saturday last but later it announced to leave Peshawar on Sunday noon. However, all of the committee members and leaders are still in Peshawar and unable to implement decision of the seconod international conference of Muslim scholars and leaders.

The members of the committee belong to Saudi Arabia, Afghanistan and Pakistan are staying in hotel Pearl Continental, Peshawar. It was learnt that Hizbe-islami of Engineer Gulbadin and Jamiat Islami of Prof Rabbani earlier made objection over nomination of Maulvi Mohammad Nabi as chairman of the committee and Maulvi Mohammad Younas Khalis as its eputy Chairman, as they are also responsible for the ongoing fighting and bloodshed in Afghanistan.

However, Secretary of the committee Abdullah Musleh, from Saudi Arabia, has assembled the members in Jamia Ashrafia on Charsadda Road and tried to convince them for initiating their efforts. The members of committee assembled in Jamia Ashrafia on Sunday noon, are busy in hobnobing with each other till filing of this report.

A spokesman of the committee when contacted, confirmed differences among its members over their departure to Afghanistan. He, however, claimed that very soon they would evolve the differences and are likely to leave Peshawar for Kabul on Monday. He said that majority of the members of the committee were sincere to their assignment but some of its Afghan members were reluctant to enter their motherland.

It may be mentioned here that Maulvi Mohammad Nabi Mohammadi is reluctant to visit his motherland. He mostly remained in Peshawar or in Saudi Arabia. He publicly announced that climate and atmosphere of his motherland is not suitable for his health, therefore, unable to visit Afghanistan. 


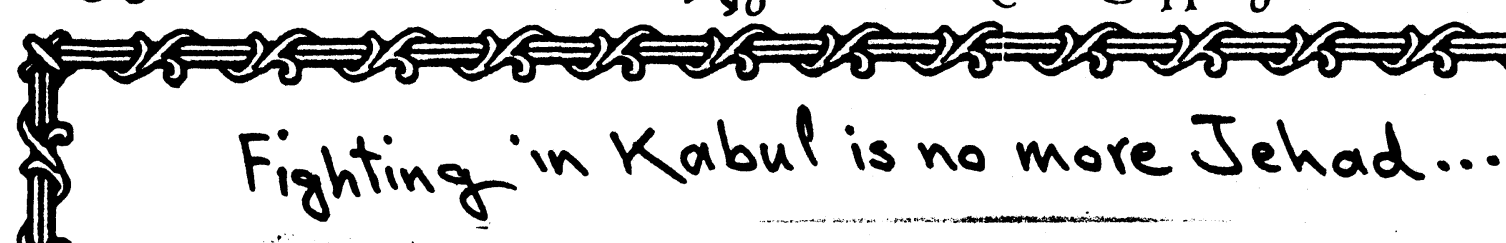

yar over the formation of interim government, Maulana Hassan Jan said that both of them are doubtful against each other. He said that Hikmatyar favoured formation of the interim government in two weaks while Prof. Rabbani says that it needs a minimum period of two months. Likewise, Engineer Hikmatyar opposes the idea of Loya Jirga or Majlis Shura for the formation of interim government saying that only Jehad leaders should set for the formation of interim government.

Answering to a question, Maulana Hassan Jan confirmed that both Engineer Hikmatyar and Prof. Rabbani were not sincere to promises and agreements aimed at an end to useless fighting and bloodshed in Afghanistan. He said that after the resignation of former President $\mathrm{Dr} \mathrm{Na}$ jibullah, there was no need for such type of fighting among the Mujahideen factions. He was of the view that as a result of conspiracies, Mujahideen forces are fighting against each other. He alleged that Maulana Hassan Jan dispelled the impression that Ulema delegation visited Kabul for sabotaging the recent peace initiatives of the United Nations. He said that United Nations was dominated by the Americans which is not sincere to Islamic and Jehad forces. He said that being Muslims, responsibility rests with them to resolve differences between the two Jehad leaders and enable them for adopting a joint strategy for the formation of an Islamic government in Afghanistan. He also said that Ulema peace committee, during its week long stay in Kabul never discussed the peace initiatives of the United Nations with the rival Afghan leaders.

Maulana Hassan Jan despite declaring the ongoing fighting and bloodshed in Kabul as unislamic, inhuman and immoral was reluctant to declare a Fatwa against both Engineer Gulbadin Hikmatyar or Prof. Rabbani. Defending the Jehad forces Maulana Abdul Rahim Chitrali said that Fatwa should be declared against agents of what he called Russians and Americans.

However, Maulana Mohammad Yousaf Qureshi severely criticised both Engineer Gulbadin Hikmatyar and Prof. Burhanuddin Rabbani as both of them are killing helpless and innocent people for their vested interests. He said that even Hikmatyar has disagreed with their requests not to kill innocent people and not to deprive them of food items and other belongings. He said that acts of both the rival Afghan factions against the helpless people neither moral nor Islamic. He said that even Hikmatyar and Rabbani refused to hold ceasefire to their useless fighting for the sake of Almighty Allah and his creation.

\section{NATION 19 APR 1994}

\section{Parcham factions protecting each other's interests}

\section{From Our Correspondent}

PESHAWAR - Despite losing power in Afghanistan and splitting into dozens of groups, the activists of Parcham faction of former ruling Watan Party, (Peoples Democratic Party of Afghanistan), are protecting the interests of each other and are struggling to cooperate amidst uncertain situation in that country.

Sources informed that recently the Governor of Khost province initiated an operation against the supporters of previous government and arrested more than 150 activists of previous Watan Party. In this operation a large number of people, who remained inside Afghanistan during Babrak Karmal and Dr Najibullah's era, have left Khost province for the nearby tribal belt of North Waziristan Agency.

"Ft this"stage one Maj. Badshah Mir, who left Afghanistan, when Hafeezullah Amin came into power come forward for the protection of his like-minded supporters, who were loyal to Babrak Karmal. Badshah Mir was considered amongst the active leaders of Parcham faction of former PDPA and loyal to Babrak Karmal. The former Afghan President Dr Najibullah was also affiliated to the said faction, but he was much popular amongst both the Parcham and Khalq factions of PDPA.

Sources said that Badshah Mir, who was now supporting the Mujahideen leaders, helped around 60 people release from the prisons of the Mujahideen leaders, ruling the Khost province of Afghanistan. In return, the released activists paid one lakh Afghani to the Governor of Khost as fine through Badshah Mir. After being released, all these activists of the Parcham faction have left Khost for unknown places. However, majority of them shifted to the nearby tribal belt.

It was further learnt that there were more than 80 people behind the bars in Governor Abdul Qayum Khan's prison. All these people were considered associates of the Khalq faction of Watan Party. At present, former defence minister Shah Nawaz Tani is considered amongst the top leaders of the Khalq faction of Watan Party. Shah Nawaz Tani after engineering an abortive coup against former Afghan President Dr Najibullah on March 6, 1990, had got political asylum in Pakistan.

The Afghan sources informed that relatives of the said prisoners are arriving in Peshawar and Islamabad to contact Shah Nawaz Tani or his supporters in order to seek their help for the release of the arrested persons. Those who left Afghanistan in miserable condition were staying with their friends in Peshawar.

They informed that arrested activists belong to various parts of Afghanistan particularly from Kabul. They left Kabul when both Hikmatyar and Rabbani entered into fierce fighting for power in January 1. 


\section{Jalalabad civilians facing hardships}

\section{From Our Correspondent}

PESHAWAR - The helpless and armless Afghans are not only facing difficulties in Kabul as a result of fierce and horrible fighting among the warring Afghan factions in Kabul, but also they are facing threats to their lives and properties in Jalalabad, capital of border Nangarhar province, due to inhuman and immoral attitude of armed guards loyal to Governor Abdul Qadeer. In Jalalabad, a joint Shura, controlling affairs of the border province and majority of its members affiliated to various warring forces. However, the stalwarts of Hizbe Islami (Khalis) is holding key positions both in administrative and security sides. The Hizbe Islami stalwarts and their armed supporters consider themselves uncrowned prince of the area. These armed guards, loyal to the Shura members have made lives of the helpless people miserable, particularly of those who have left heir homes and properties at Kabul due to ongoing bloodshed and destruction at hands of forces loyal to both president Burhanuddin Rabbani and Prime Minister Engineer Gulbadin Hikmatyar.

Some Afghan sources in Peshawar told The Nation that recently, Nadar Arab, incharge of security guard of governor Haji Abdul Qadeer made his own rules and regulations. Nadar Arab not only misuses his position but even established his own prisons and lock ups where he make prisoners those people who disobay his orders. He is regularly receiving ghunda tax from the shopkeepers and vehicle owners in the area, the sources added.

It was learnt that Nadar Arab being patronised by Engineer Mehmood, chief of the security forces and Asef Khan. Both of them are close associates of Haji Abdul Qadeer. Engineer Mehmood is considered amongst the billionaire Afghans as he owns some DC-10 planes, chartered with the Pan Americans in Kuwait. It was further learnt that Shura members through Nadar Arab not only kidnapping the helpless boys and girls but even they misappropriate the foreign aid, being provided to war-displaced Afghans, settled by the UN's High Commission for Afghan Refugees in Hasarshahi camp, 20 kilometres east of Jalalabad. Some confidential sources said that Shura members and leaders have deposited thousands tonnes of wheat, flour and other relief goods in Jalalabad. They misappropriated all these goods, sent by various countries and donor agencies for the relief of war displaced civilians of Kabul.

The sources maintained that Nadar Arab, a partner of Mehmood and Asef Khan has stored 50,000 metric tones of wheat in jalalabad. The wheat was supplied by the UNHCR and other donor countries to the Nangarhar Shura of Jalalabad for its distribution amongst the war displaced civilians. In this connection, Nadar Arab also enjoys support of some high level dignitaries or the national logistic cell (an subordinate institution of Pakistan, responsible for transportation of relief goods to Afghanistan for war displaced people). Now, 50,000 metric tones of wheat, stored in Jalalabad to be sold at flour mills owners of Pakistan or at hands of the Afghan traders, owning flour machines. In this connection, volunteers of some Afghan and foreign non-govt organisation are also playing role of brokers for Nadar Arab.

NATION

O 5 APR 1994 

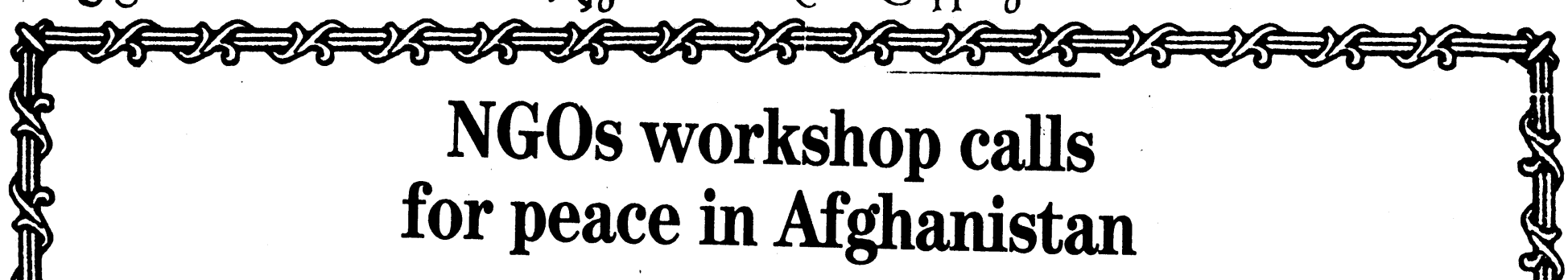

\begin{abstract}
Bureau Report
PESHAWAR: The participants of a workshop on 'NGOs and Peace in Afghanistan,' held in Swat have appealed to all concerned to join in the effort to restore peace in the war-ravaged country.
\end{abstract}

The five-day workshop was arranged by the Norwegian Church Aid and the Norwegian Refugee Council, which operate out of Peshawar. Officials of a nuniber of NGOs busy extending humanitarian assistance to the Afghans attended the workshop.

The appeal by the workshop participants declared: "Peace is an emergency; Peace is the foremost concern and the most dire need of the Afghans and the NGOs commu- nity; Peace is a basic right of the Afghan people; Without peace, reconstruction of the country cannot take place; Without peace, the refugee population cannot return to their homes; Without peace, suffering continues; After so many years of war, destruction and suffering, it is time to make peace and freedom a reality in Afghanistan."

The appeal was directed primarily to the Afghans responsible for bloodshed in Afghanistan. It was also aimed at all parties involved in the perpetuation of suffering of the Afghans. The appeal was also directed to the international community, hoping it could play a constructive role and prevent the ongoing tragedy from being prolonged.

\section{Afghan war caused arms price rise}

From Shamim Shahid

PESHAWAR - As a result of fighting amongst the warring Afghan factions in Kabul, prices of modern and sophisticated weapons are increasing rapidly the arms market of Darra Adam Khel.

During a visit to Dara Adam Khel arms market, situated $40 \mathrm{~km}$ away from Peshawar, it was witnessed that Mujahideen commanders and their agents were busy in purchasing their once sold arms and immunition to export to the war affected Afghanistan.

However, it was observed that prices of heavy weapons are going up giving opportunity to the arms dealers to accumulate money. Some of the Mujahideen commanders and their agents are seen selling light weapons like of Soviet made pistols at hands of arms dealers.

In the beginning of 1992, when the United Nations was busy for implementation of its five-point formula for resolving the Afghan conflict, prices of the modern and heavy weapons were decreased as compared with prices in 1990 and 80's. At that time, the dealers had purchased Soviet made klashnikov, known as "karawal" with Rs. 14,000 while its previous price was Rs. 35,000 . Now once again the said klashnikov is being sold at from Rs. 16,000 to Rs. 20,000 in Dara Adam Khel market. Mujahideen leaders received these klashnikovs from the troops, loyal to former Afghan presidents Dr Najibullah and Babrak Karmal. The said klashnikov was first introduced soon after invasion of the former Soviet troops in Afghanistan in December 1979.

The China made klashnikov, gifted by China to Afghan war lords during Afghan jehad is now being sold at Rs. 16,000 while its January 1992 price was registered Rs. 14,000 Before 1992, price of a Chinese klashnikov was more that Rs. 18,000. Earlier, common Russian klashnikov was being sold from Rs. 18,000 to Rs. 20,000 but Mujahideen themselves sold such type of guns at Rs. 8,000 in January 1992. Now they are again purchasing the said klashnikovs at Rs. 10,000 .

Before establishing Mujahideen's government in Kabul, prices of Dashaka, a known heavy weapon, was being sold at Rs. 40,000 but now it was purchased by Afghan war lords at Rs. 50,000. Interestingly, Mujahideen commanders sold Dashaka at Rs. 28,000 when they entered Kabul victorious in April 1992. In Dara Adam Khel, it was witnessed that Dashaka like heavy weapons were being sold like hot-cakes.
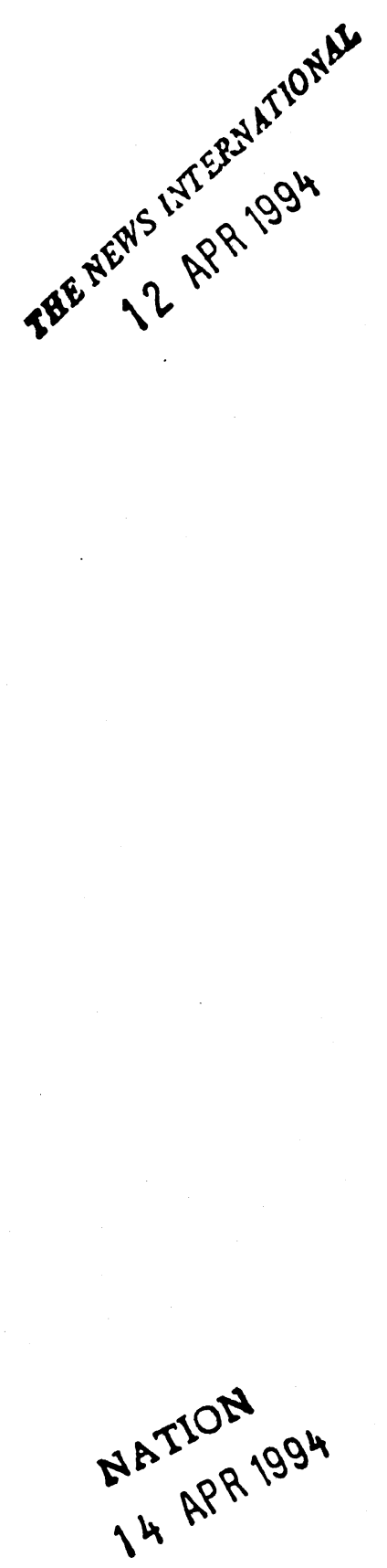


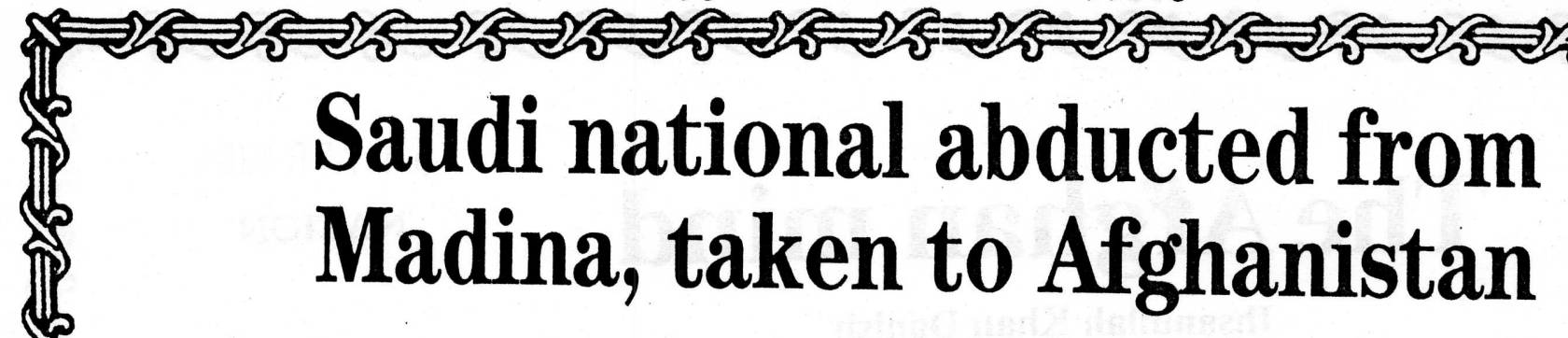

\begin{abstract}
From Rahimullah Yusufzai
PESHAWAR: A Saudi national abducted from Madina Munawwara has been taken to Afghanistan by two Afghan cousins who claimed he owed them 480,000 Saudi riyals.

Mansoor Jadad Sahan al-Fagir alAnzari, 26, is being held in the Wazey district of Paktia province bordering Pakistan. The exact location where he is kept is not known. However his abductors, Haji Nauroz Khan and Mohammad Ayub, said in two letters to this correspondent that the Saudi was being held in the mountainous area between the towns of Gardez and Khost.

The letters, penned in Pashto, claimed Mansoor was abducted about ten months ago. They wanted this correspondent to publicise the news about Mansoor's abduction in the newspapers and on BBC's Pashto and Arabic services. They also sent a picture of Mansoor for publication.

Mansoor also wrote a letter to this correspondent, explaining his predicament and wishing that the news about him is widely circulated. He said he had written earlier to magazines while the Saudi embassy is also in knowledge of this case but no effort was made to secure his release. "I am being held in one place and suffer from respiratory problems," said the letter written in Arabic.
\end{abstract}

He conceded that he owed
480,000 riyals to his abductor, Ayub Zadran, and that his captors were within their right to demand payment of the money. "However, they don't allow me to go and arrange this amount," complained Mansoor.

Haji Nauroz and Ayub, both belonging to the Zadran tribe, said

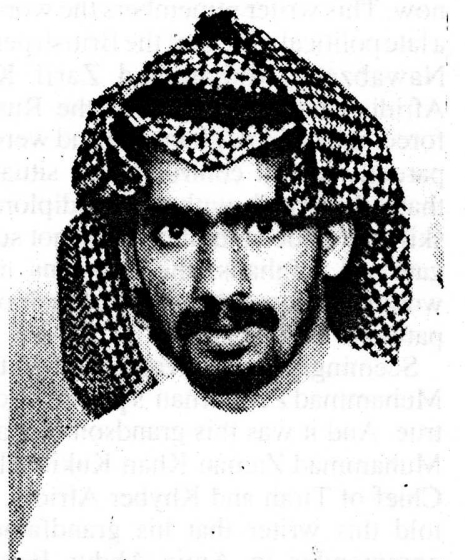

Mansoor Jadad Sahan al-Faqir alAnzari.

his death, the responsibility would rest with Mansoor's family and Saudi Arabia's ambassador in Pakistan as they were aware of his illness," warned the letter.

The two Afghan cousins said they kidnapped Mansoor when he refused to honour their business dealings concerning visas. Moreover, they Mansoor was seriously ill. "In case of

charged Mansoor with denying payment of cash owed by him and grabbing possession of their two shops and Mercedez truck fitted with a water tanker in Medina. They said the Saudi embassy in Pakistan and the United Nations offices in Peshawar were promptly informed about the abduction. They added that mujahideen administration in Gardez and the UN sub-office in Khost were also aware of the matter.

An Afghan on condition of anonymity told 'The News' on phone that Haji Nauroz and Mohammad Ayub had spent ten years in Medina and made some money through hard labour. "But Mansoor refused to entertain any request after seizing the total savings of the two Afghans," he argued. Justifying the abduction, he said there was no other way of seeking payment of money from the resourceful Saudi national.

The abduction of the Saudi national to Afghanistan has been disclosed in the wake of the recent kidnapping of a Pakistani deputy commissioner by an Afghan commander, Abdul Salam Rocketi, from Balochistan. Rocketi, piqued by the arrest of his brother and recovery of two Stinger missiles and some money from his base by Pakistani law-enforcing agencies, is also keeping hostage seven Balochistan government officials and two Chinese engineers in his native $\mathrm{Zabul}$ province.

pealed to the provincial and federal governments to extend the date of their extradition but the appeal was refused.

In this connection, a meeting was held at the Governor's House which was also attended by the commissioner Afghan refugees and the home secretary. The meeting decided to launch a massive crackdown on the Arab na. tionals. The task was assigned to the special branch but a senior branch official said that he had not so far received any directives from any quarter. He said that he was busy in a number of other as signments.

A provincial government official said that orders would definitely be implemented by the federal government and no extension in this regard would be possible. $\mathrm{He}$ said that 15 nationals of Algeria, Tunisia and Egypt had left Pakistan for their respective countries. The Arabs who had got air tickets or exit permits would be allowed to stay till tomorrow (Friday). Protection would be provided to the family members of those arrested under 14 foreign act.

It is to be noted here that the present government had thrice given extension to the nationals of three countries. They had been here ever since the start of Afghan war. The health and construction work in Afghanistan was said be supervised by them.

\section{ERONTIER POST}

21 APR 1994 them"

It may be mentioned here that April 18 was the deadline given to the nationals of Algeria, Tunisia and Egypt by the federal government. These nationals have ap- 


\section{Ihsanullah Khan Danish}

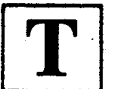

hijacking of a school bus with 86 children and staff aboard, followed by armed ransacking of Pakistan Embassy in Kabul and, howsoever limited, the crossfire at Torkham, have justified the worst forebodings of those who have an.insight into Afghan history. That a neighbouring country has helped another in its defence or given shelter to the latter's refugees, does not necessarily mean a permanent bond of diplomatic cordiality between the two countries. Afghanistan is no exception especially in the light of the internal instability the country is suffering from ever since the withdrawal of the former Soviet Union's forces.

The factors leading to Afghan disillusionment with Pakistan are numerous, ranging from discrimination between various types of refugees to rampant corruption in the distribution of foreign and Pakistani aid. The common Afghans living in Pakistan in their own constructed mud villages were, so to speak, like a candle burning at both ends - on the one end by the Pakistan Government functionaries and on the other by their own leaders. Though being thankful to Almighty Allah and the people and Government of Pakistan, these refugees have developed resentment due to the aforesaid factors.

The moneyed and privileged Afghan class residing in Pakistan as refugees, however, in most cases, did so under compulsion. They were modern, educated in the former Soviet Union, and motivated against Pakistan during the Daud era with a tilt towards India, despite the fact that the latter country refused to accommodate them because of her connections with the erstwhile Soviet Union. As such Pakistan was playing host to a resentful but apparently contented middle and lower middle class of Afghan refugees and was also giving shelter to the disgruntled anti-Pakistan elements of Afghan society of the post-Sardar Daud era. Given all sorts of facilities for their own protection, inclusive of permission to maintain a well-knit tight security system with retention of lethal arms, the privileged Afghan class was overpampered by the Zia regime and permitted to freely move not only in NWFP but the whole of Pakistan.

We, thus, bred a generation of Afghans who were not only deeply involved in the intra-territorial politics of Pakistan, but also allowed them to travel through the hills and dales of NWFP without any let or hindrance. While, on the other hand, Afghanistan was a closely guarded country so far as its topography was concerned before the Jehad started and after the Russian invasion it was all the more difficult to undertake a risky journey through Afghanistan. As such, while the Afghan understanding of the Pakistani situation was no problem, it was next to impossible to

understand the Afghan mind. The previous NWFP generation that had an insight into the Afghan social and political structure till the British raj is almost gone by now. This writer remembers the words of a late political officer of the British period, Nawabzada Muhammad Zarif Khan Afridi, who told me when the Russian forces attacked Afghanistan and were apparently in full control of the situation, that if the British-with all their diplomatic skill and understanding could not subjugate the Afghans, the Russians never would, whatever the length of their occupation of Afghanistan.

Seemingly unbelievable at the time, Muhammad Zarif Khan's prophesy came true. And it was this grandson of Nawab Muhammad Zaman Khan Kukikhel, the Chief of Tirah and Khyber Afridis, who told this writer that his grandfather, a commander in Amir Abdur Rehman Khan's troops who captured Kabul for the Amir-latertitled as Nawab by the British government - would advise his people against going to Kabul for a prolonged stay, as the Nawab Sahib used to say that having stayed and served in the Amir's army in Afghanistan, he had come to the conclusion that a one-half of bread at home was better than a whole one in Afghanistan. Obviously, the Nawab Sahib was referring not to the common Afghans but the system of administration in Afghanistan and the attitude of the ruling hierarchy of that country, which were jealous and suspicious of one another. Being an insider, Nawab Muhammad Zaman Khan knew far more than what he would divulge from time to time. But some British chroniclers touring Afghanistan and gathering information from here and there have stated that men and women sitting round the same meals try to be cautious, rather wary, of one another in their gossip, lest something indiscreet comes to someone's lips and is reported by their very kith and kin to the authorities.

The situation being such in a backward country with a very advanced upper class mistrustful of one another cannot but represent a closed door attitude in their dealings with others also. One can find its proof in the history of the post Ahmad Shah Abdali period (1747-73 AD) to Amir Abdur Rehman Khan's era (1880-1900 AD), when the latter restored peace and law and order with an iron hand supported by British backing. His son and successor,
Amir Habibullah Khan, was a weak but sober ruler, whose murder plunged Afghanistan, despite the successful coup of

Amir Arnanullah Khan, once again into a chaos that provided a brigand, Habibullah by name, coming from the Northern part of Afghanistan to capture the capital Kabul and occupy the Afghan throne as Amir Habibullah Chazi for about three years and later to be known as Bachas-e-Saquao for his previous background. A quarter of a decade was to elapse in uncertainty in Kabul and widespread in-fighting between various factions in the northern and southern parts of the country, before peace could be restored.

It was King Muhanmad Nadir Shah, a British hostage along with his father in Dehra Dun, an Ambassador of Afghanistan to Paris after his removal from the command of Afghan forces by his cousin and brother-in-law Amir Amanullah Khan and Nadir Shah's brothers, who saved the situation with monetary aid from the people of Peshawar and the armed support of Afghan and Pathan tribes along the Pak-Afghan Border of today. King Muhammad Nadir Shah had hardly ruled for about three years when he a fell prey to the close-range pistol fire of Gen Ghulam Haider Khan Charkhi's Ghulam Bacha (child slave). However, King Muhammad Nadir Shah's brothers and Prime Ministers during his and his son and successor. King Muhammad Zahir Shah's rule, mindful of the country's distracting history, did not venture to capture the throne. Instead they helped and supported their 19-year old nephew to firmly occupy the Kabul throne. It was because of their superb political acumen that up to the establishment of Pakistan, Afghanistan did not experience any serious problem for fourteen years. However, it was their self-invited trouble, when they refused to recognise Pakistan Government's sovereignty over NWFP and the adjoining tribal areas, as successor to the British government. Their's was the solitary vote in the UN General Assembly against Pakistan.

Afghanistan was now on a war path with Pakistan, a Muslim and brotherly country, as against the British. While his uncles did not go to the extreme. Sardar Muhammad Daud Khan, during his Prime Ministership, went too far away from Pakistan and forged cordial relations with the Soviet Union and its anti-Muslim ally, India. How one autocratic ruler can destroy his

See Next Page 
THE United Nations peace mission to Afghanistan led by the former Tunisian foreign minister appears to have been unsuccessful in its initial effort to get the warring parties to agree to a permanent ceasefire. While President Burhanuddin Rabbani is willing to accept an unconditional cease-fire, Prime Minister Gulbuddin Hekmatyar continues to insist that Rabbani's resignation is a pre-condition to peace in Kabul. The inability of the UN mission to make any real headway is not entirely unexpected given the complicated situation on the ground in that war-ravaged country. Just the current round of fighting in Kabul over the last three months is estimated to have resulted in. nearly 15,000 people being killed or wounded while hundreds of thousands have been driven from their homes and substantial sections of the city have been reduced to rubble. Further, because of the blockade of Kabul by Hekmatyar's forces that also prevents relief and food convoys from reaching the city, nearly 400,000 residents are reported to be threatened with starvation. The contention here is that such convoys could provide much needed relief to Rabbani's forces. Nevertheless, it is a measure of the extent to which the warring factions are now prepared to go in their interminable and increasingly brutal struggle against each other, regardless of the cost to ordinary civilians who more than anything else would now like to see an end to the fighting and to begin the long and arduous task of reconstruction.

The United Nations at this stage is not attempting anything ambitious. The mission aims, essentially, at ascertaining the minimum demands and conditions of the warring . factions so that it could then, hopefully, come up with a workable peace formula. But it is indicative of the uphill nature of the task that even as an uneasy truce held in Kabul during the visit of the UN envoy intense fighting continued further north between the forces of Rabbani's key military commander Ahmad Shah Masood and those of Hekmatyar's ally, the Uzbek warlord Abdul Rashid Dostum. There is in any case virtually no possibility of the various factions surrendering their weapons to a United Nations force as Gulbuddin Hekmatyar has already made clear. In this situation any kind of a military role for the UN to end the fighting is largely ruled out. However, reportedly there is possibility that UN personnel may be sent to Kabul as observers to monitor the situation. Such minimal UN presence on the ground is unlikely to achieve very much as long as the faction leaders with their maximalist demands and the unrestrained use of firepower do not come to grips with the fact that sooner or later the military stalemate must give way to some kind of a negotiated settlement. Only then can the various proposals for peace in Afghanistan such as that of holding elections, calling a Loya Jirga, etc be seriously considered for their respective merits. Meanwhile, other countries that have in one way or the other remained involved with the affairs of Afghanistan over the years such as Iran, Pakistan, Saudi Arabia, Russia and the United States should use whatever influence they have with the different factions in the country to wean them away from the all-or-nothing frame of mind that appears to be dominating the proceedings in Afghanistan.

\section{The Afghan...}

people and country can be judged from Daud's one-track mind and unbalanced foreign policy after he staged a successful coup against Muhammad Zahir Shah and then fell a prey to his own communist motivated armed forces, leaving the Afghan people to be devastated by his com-

munist successors and forces of their patron country.

Though shamefully defeated at the hands of the Afghan Mujahideen - at a huge cost to the Mujahideen and the Afghan people at large, of course - the Soviet forces' agents and sympathisers in Afghan society succeeded in widening the already existing gulf between the various Mujahideen groups. No wonder a stable government has not so far come to power in Afghanistan. Nor is one expected in the near future since Jehad has given way to anarchy that suits the temperament of the trigger-happy elements among the Mujahideen and their allies' camps. Loot and plunder is, therefore, galore and $\mathrm{mu}$ tual bloodshed unlimited as the fourteenyear long Jehad has not yielded the desired results. Instead of motivating the refugees and Mujahideen in favour of Pakistan, our government functionaries have done more to offend their sensibilities and antagonise them. Resultantly, there is a feeling of hurt rather than respect that the Muslim refugees are entitled to. One cannot, therefore, be sure of their thinking about Pakistan. And the cardinal factor is the existence, after destruction and ultimately resurgence, of the Communist-oriented administrative set-up in Afghanistan in consequence of the vacuum created by the sudden abdication of the last communist ruler, Dr Najib.

No country can achieve stability without an administrative infrastructure, which in the current Afghan situation has been totally destroyed due to the in-fighting of the Afghan Mujahideen groups. A semblance of administration could be restored by Najib government functionaries, whatever their political or religious beliefs. Alternatively, when invading armies capture a territory - and the position of Mujahideen conquest is nearly the same but for the lack of a unified command military administrators provide the upper strata of civil administration, making use of the vanquished government functionaries at the lower level. Afghanistan unfortunately deprived of this alternative mostly due to the stubbornness of the different groups and partly due to the Ziaul Haq regime's lack of foresight in not making determined efforts to bring the various Mujahideen groups under one, single command. And this is something which the present Afghan intellectuals anti-Pakistan mostly in the heart of their hearts - and the future Afghan historians would blame Pakistan for, as the patron of the Afghan Mujahideen.

In the circumstances, we in Pakistan must realise in cool consideration of the recent violent happenings in Peshawar, 
DESPITE the utter fragility of the temporary ceasefire arranged by him and little tangible progress in his peace mission, the special UN envoy to Afghanistan, Mehmoud Ali Mestiri, may yet succeed where many other peace initiatives before have failed. In his separate meetings with President Burhanuddin Rabbani and Prime Minister Gulbaddin Hekmatyar, he secured the assurances of the two top Afghan leaders' commitment in principle to an end to the factional war, provided there was no loss of face. Prime Minister Hekmatyar reportedly suggested a way out of the impasse when he proposed to Mr Mestiri on Sunday that both the President and the Prime Minister should simultaneously resign from their present posts and make way for an interim government. (Till the time of writing, this report remains uncontradicted.) If a broader agreement could be reached on this line, Kabul could soon have an interim government with the specific objective of holding elections for a constituent assembly. That, hopefully, would lead to a smooth and orderly transfer of 13 power to the elected representatives of the Afghan people. On Sunday, President Rabbani told journalists accompanying Mr Mestiri that he was ready to accept a permanent and uncon ditional ceasefire provided the Same was also acceptable to Prime Minister Hekmatyar.

The pitfalls besetting the path to a durable peace in Afghanistan should not be under-estimated, however. $\mathrm{Mr}$ Hekmatyar's proposal appears to be the only ray of hope, in the Pmidst of the unrelieved gloom of a seemingly unending and Ssenseless war. Even as Mr Mestiri emerged from his meeting with President Rabbani, the bursting of shells in the neighbourhood of the presiden1 tial palace came as a grim $\int$ reminder of how bad and unpredictable things are in war-ravaged Afghanistan. In the intermittent fighting in the three months preceding $\mathrm{Mr}$ Mestiri's arrival in Afghanis tan, some 15,000 Afghans had been killed and wounded and thousands others rendered homeless. If the present ceasefire is not extended, the UN peace envoy would have only a few hours more to evolve an agreement on Mr Hekmatyar's formula for ending the war. He would also need to secure the cooperation of other strong men such as Ahmad Shah Massoud and Rashid Dostum, who are now aligned with opposing sides.

Somewhat disturbingly, there is a persistent feeling among Afghanistan-watchers based in Peshawar that many Mujahideen leaders, including President Rabbani and Prime Minister Hekmatyar, are opposed to a meaningful UN peace-making role in Afghanis tan. They are reluctant to share power with others or to let neutral government manage the affairs in Kabul even on a short-term basis. An interim government could impede their capacity to manipulate the elections, as and when they are held, to their respective advantage. However, there can be no doubt that the Afghan masses, who are the ones who have suffered the most in the long factional war, would look up to the UN not to give up on its role as peace-maker and to try to restore a semblance of order in their war-ravaged country. It also goes without saying that it would be only with the end of the war in Afghanistan that Pakistan would begin to be relieved of the burden of the hundreds of thousands of Afghan refugees who are still shattered here. $\mathrm{Mr}$ Mestiri's peace mission is on a short fuse though; he does not have much time to make the Afghan leaders agree on formula for peace.

\section{UN peace mission to Afghanistan}

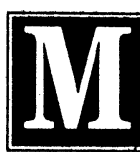
ehmoud Mestiri, the leader of the United Nations peace mission to Afghanistan who has already held an initial round of talks with the main warring Afghan leaders, apparently faces a much bigger problem than expected. The obduracy of the various factions, which had till now obstructed any solution, came out strongly before the UN mediator. The leaders lost no time in making it clear that short of their long-held positions, no peace was possible. With the entrenched President Burhanuddin Rabbani refusing to quit and Prime Minister Gulbadin Hekmatyar equally determined to see the last of him, leaves little margin for any solution.

Similar peace efforts by Pakistan and a few other countries had foundered on the same rocks of obstinacy now troubling the Mestiri mission. But it is quite likely that the weight of the UN could be a sufficiently strong persuasive factor to bring about a peace settlement. While sympathetic nations can, at best, make limited promises of help, the world organisation is better placed to offer a comprehensive package of peace for rehabilitation and reconstruction.

The Afghan leaders might yet be persuaded by such a proposal to abandon their meaningless war of self-destruction if the future seems sufficiently bright to stop fighting for. After all, an offer by the UN cannot be easily rejected when it is at present the main source of succour of aid and relief for the embattled people. But any such effort by the UN must be accompanied by a greater sense of commitment than has been shown so far. Apart from a fairly weak resolution and a few brief peace forays by itinerant visitors, the world organisation has done little compared to its heavy involvement in other trouble spots. Much of the burden of trying to bring peace has naturally devolved on Pakistan, a task that is more often than not thankless.

A UN peace mission, therefore, was fairly overdue, not only on account of the endless violence, but because the leaders themselves favoured such an effort. If there was anything on which there was a tacit consensus in the long-troubled country, it was their hope in a UN peace effort. It is in such a light that it can be expected the Afghan warlords, behind their tough outward inflexibility, might well be inclined to reach a settlement. The bloody conflict has really got them nowhere and even after fighting for almost two years the chances of one or the other side emerging triumphant are remote.

It seems the Afghan leaders have failed to understand a basic fact that the longer they fight, the less the chances of peace. The Somali leaders, too, got caught in such a maze, and now in spite of an international effort to save their people from starvation and death, they are still far from a resolution of their differences. In political terms Afghanistan is not much different, although the people, despite the destruction, have not been reduced to the circumstances of the Somalis. But given the ruthlessness of their warlords, it will not be long before Afghanistan ceases to have any meaning as a nation. Pakistan, Iran and other neighbouring states dread such an eventuality.

TVNOILVNYIINI SMAN GHL.

\section{DAWN 06 APR 1994}




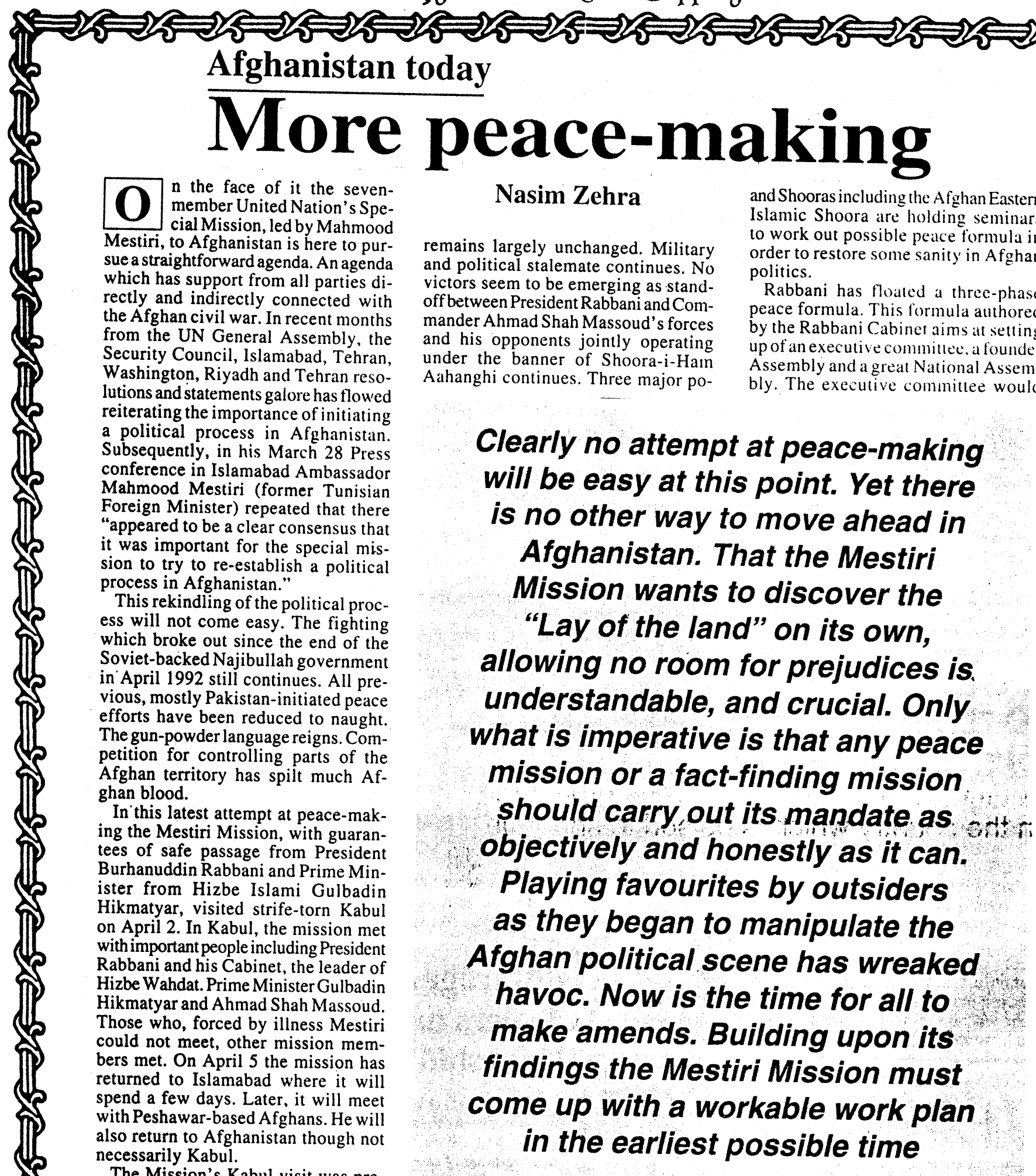

The Mission's Kabul visit was preceded by visits to Jalalabad and Peshawar. In Jalalabad, Mestiri and his men met with Governor Haji Qadir and members of the Nangharhar, Laghman and Kunar shooras. He also addressed a gathering of about 100 intellectuals elders, commanders and ulema. UNHCR officials too have met the mission to report on difficulties they face in carrying out their operations.

The ground situation in Afghanistan

litico-military forces of Dostum, Gulbadin Hikmatyar of Hizbe Islami and of Hizbe Wahdat have joined together in this Shoora. Fighting continues in the Kunduz area. Here RabbaniMassoud forces control the inside areas while Dostum-Hikmatyar forces control the entry points.

Meanwhile, different Afghan groups perhaps propelled by the Mestiri Mission are tossing out new peace proposals. Inside Afghanistan private groups include all Mujahideen leaders.

Anyhow the initial response to this Rabbani effort has not been encouraging. Political men like those of Shoora-

i-Ham Aahanghi and intellectuals like Professor Rasul Amin of Writers Union of Free Afghanistan have outrightly rejected the plan. Former President Sibghatullah Mujaddedi refused to meet the four-member delegation Rabbani sent off to Peshawar for gathering sup- 
port for his Cabinet's peace formula:
The general impression remains that Rabbani is determined to hold on to power by hook or by crook.

Hikmatyar in his meeting with mission members has merely repeated his earlier demand that President Rabbani must resign to allow a genuine peace process to get moving. Other leaders including Maulvi Nabi Muhammad and

Maulvi Younus Khalis have declared their neutrality in the current civil war. They have called for a political settle nent under the UN auspices.

In Islamabad, the Mestiri In Islamabad, the Mestiri Mission has been wirmly welcomed. But nothing more. Pakistan's expectations from the Mission are from the Mission are not very high. At the son iust vet to be enthusiastic ahout the

\section{APR 1994 NATION}

\section{Mullah Rocketi}

HAVING exhausted the informal channels it had been using to persuade the Afghan outlaw, Mullah Salam alias Mullah Rocketi, to release the Chinese engineers and officials of the Balochistan government he kidnapped some time ago, our Foreign Office has now taken up the matter directly with the government in Kabul. It summoned the Afghan Ambassador to tell him that his government must use its influence to secure the release of the abductees and also to stop Mullah Rocketi's criminal activities on Pakistani territory which include, besides abductions, rocket and mortar attacks on some border security posts along the Pak-Afghan border in Balochistan. For reasons that are understandable enough, studied restraint has to be an important feature of this country's dealings with all matters concerning Afghanistan, but at the same time there seems to be little justification in handling these with the kind of kid gloves that has so far characterized the handling of undesirable Afghan nationals' activities on the Pakistani soil. In Mullah Rocketi's case, the revelation that he belongs to Professor Sayyaf's group, which is a coalition partner of President Rabbani's government, is particularly disturbing. Of course, it is quite possible that neither the President nor the Professor, both of whom enjoyed Pakistani hospitality for a long time during their years of struggle against the foreign enemy, have anything to do with the matter. The Mullah may be acting and and thus may be enjoying their protection, makes them responsible for all the crimes that he has been committing in this country.

Equally disturbing is the report that Ahmad Shah Masood, President Rabbani's right hand man, may have been responsible for the kidnapping of two Pakistani students from Kabul. One can only hope the report is the the attackers of Pakistan's Kabul Embassy had the implicit blessings of in Kabul it is bad news for the prospects of theat is the way the things are and advised the Afghan this side of the border. Our Foreign Office has rightly Mullah the release of all people that Mullah Rocketi has kept captive and to bring him to book for all the other means at its dispeen committing here. It should also be looking at some other means at its disposal to bring an effective end to the Mullah's menace.

\section{NATION}

06 APR 1994
Mission. Pakistanis believe that unless the military stalemate breaks and the ground situation changes no amount of "fact-finding" can be put to much use. According to Pakistani officials. "We do not anticipate any change; neither is there any definite clear-cut initiative being put forward nor is there any sign of any clear victor among the warring Afghans."

Meanwhile, Islamabad's Embassy in Kabul remains closed. Two problems of securing the former British Embassy's premises for the Pakistan Embassy and getting guarantee from the Rabbani government for security of its staff have yet not been resolved.

Any viable attempt, national, regional or international effort at rehabilitation of the Afghan society must include a political and military package. While the need for a political set-up has often been reiterated the fundamental need for setting up an Afghan national army has been overlooked. The Afghan national army no longer exists. It has simply disintegrated into militias. For any interim set-up to succeed it requires the muscle power to establish its writ and to ward off attacking militias. What is out for the UN on the Afghan front is any role that requires a commitment of men and money. "UN will play a role only on the cheap," concede UN officials. UN officials expect no help from the UN in helping Afghanistan to re-establish a national army. Instead UN officials hope that professional Afghan soldiers, now waiting it out can help in setting a national army. They believe financial and professional help should come from OIC countries like Bangladesh, Morocco, Pakistan, etc.

An OIC Mission led by Al-Bakr, Assistant Secretary of OIC, arrived in Pakistan on April 3 to assess the Afghan situation. According to $\mathrm{Al}-\mathrm{Bakr}$ "The OIC and the UN have closely coordinated their efforts for restoring a durable peace in Afghanistan." The Bakr mission is looking into the possibility of establishing an OIC office on Afghanistan in Islamabad.

Clearly no attempt at peace-making will be easy at this point. Yet there is no other way to move ahead in Afghanistan. That the Mestiri Mission wants to discover the "Lay of the land" on its own allowing no room for prejudices is understandable, and crucial.

Only what is imperative is that any peace mission or a fact-finding mission should carry out its mandate as objectively and honestly as it can. Playing favourites by outsiders as they began to manipulate the Afghan political scene has wreaked havoc. Now is the time for all to make amends. Building upon its findings the Mestiri Mission must come up with a workable work plan in the earliest possible time. 


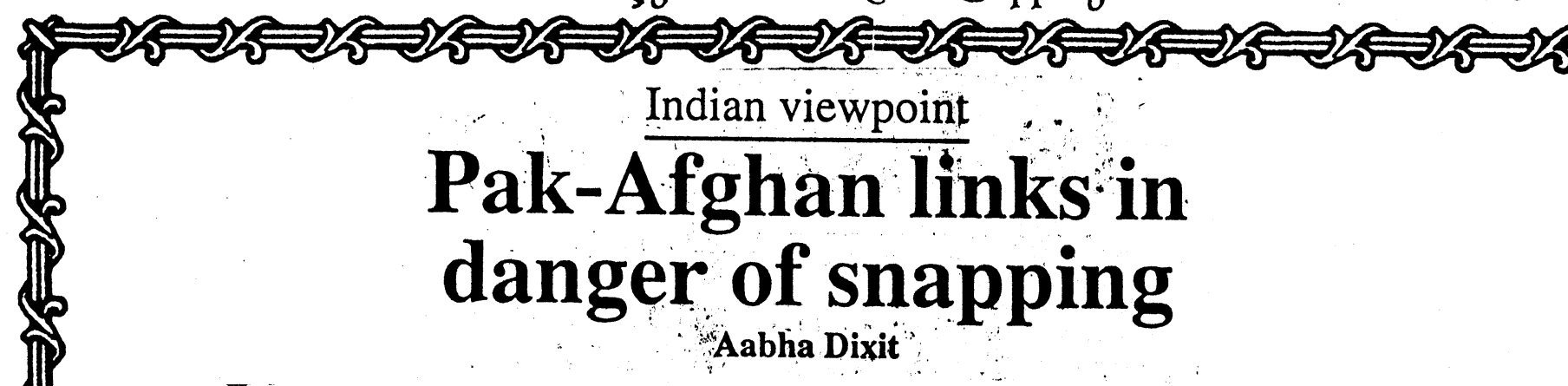

After years of playing with fire, Islamabad's mujahideen connection is beginning to suck it into the Afghan cauldron. A spate of unsavoury incidents recently have revealèd that the expected Afghan backlash is under way. The hijacking incident in Peshawar followed by a mob attack on the Pakistan embassy in Kabul have pushed Pak-Afghan relations to a new low.

Ever, since the Soviets left, there has been a deep divide within the Islamabad establishment over its Afghan policy. The hardline elements continue to uphold the line that the Soviet vacation of the country was merely one phase in the jihad they had launched, whose logical conclusion was to place a pliant government in Kabul. This government would maintain a special relationship with Pakistan and end support to the Pakhtunistan movement by accepting the Durand Line as the international boundary. Towards this ambitious policy, the $\mathrm{Zia}$ regime. cultivated Gulbaddin Hekmatyar, who appeared the most uncompromising mujahid.

2 Self-serving intent: By putting all its eggs into the Hekmatyar basket, Islamabad virtually closed all its options to become an honest broker in the post-Najibullah scenario. The failure to remove the element of mistrust that characterised the other mujahideen groups' response to Islamabad led the establishment in 1992 to try and change its tracks. But this came too late for other mujahideen leaders not to see through its self-serving intent.

Secondly, Islamabad took the decision to "ditch" Hekmatyar when a power struggle among the numerous groups for the control of Kabul had already broken out. Most importantly, while Islamabad officially severed its ties with Hekmatyar, several institutions within the establishment, like the ISI and military intelligence, continued to maintain their links with him.

Through the civil war, Islamabad has been consigned to the margins, with a marked inability to bring all the warring factions into a government of national reconciliation. Several attempts, including the Islamabad, Peshawar and Jalalabad accords, broke down, with Pakistan continuing struggle with a monumental refugee problem.

Having provided shelter to over three million Afghans during the 1980s, the deleterious effects of covert destabilisation were beginning to be noticeable inside the

country. Afghans were given the opportunity to own property and conduct businesses. Through the 1980s, the economy of NWFP and Balochistan was dominated by drugs and arms smuggling. A close nexus between local politicians and Afghan mercenaries saw spectacular increases in sectarian and ethnic violence throughout Pakistan.

Clear policy: The first signs of a clear policy of delinking from Kabul became evident in Ms Bhutto's second term. By symbolically closing the gates at Torkham, she tried to move cautiously in attempting to stop the

\section{ERONTIER POST}

10 APR 1994 free flow of refugees across the "open" border.

The closure of the supply lines meant a direct disadvantage to mujahideen groups with bases inside Pakistan. While Masood, Dostam had built up an organisation in the northern areas, Abdul Rashid Dostam is reported to have maintained cross border contacts in Uzbekistan. The biggest loser from increased Pakistani military presence along the Durand Line was Hekmatyar, whose strategic reserves continued to remain in NWFP. In retaliation, Hekmatyar refused to allow food convoys from Peshawar.to reach Kabul.

As Kabul was battered by the worst-ever fighting, that left over 1,000 dead and 12,000 injured, the non-supply of food and essential items provoked an instant attack by three Afghans who commandeered a school bus in Peshawar, taking eighty children hostage. Although the hijackers were killed, it was evident that ordinary Afghans equated $\mathrm{Mr}$ Hekmatyar with Islamabad.

Kabul and Islamabad retorted with sharp diplomatic missives, with the latter seeking to implicate the Indian intelligence agency for the bus hijacking. But subsequent events in Kabul gave lie to the conspiracy theory and revealed the pent-up feelings that Afghans harboured lowards Pakistan. Three hundred men stormed the Pakistani embassy in Kabul while the foreign minister, Assef Ali, was negotiating a new peace deal with Rabbani.

But Afghan opinion is increasingly veering around to the perception that Islamabad's self-serving policies are to be blamed in large measure for preventing Afghanistan's return to normalcy. As the war of words between the two countries escalates, there are many in Islamabad who are loudly protesting the inability of the Afghans to be "grateful" and have been demanding that the Afghans be reminded that their only supply ines come from the south.-The Times of India 


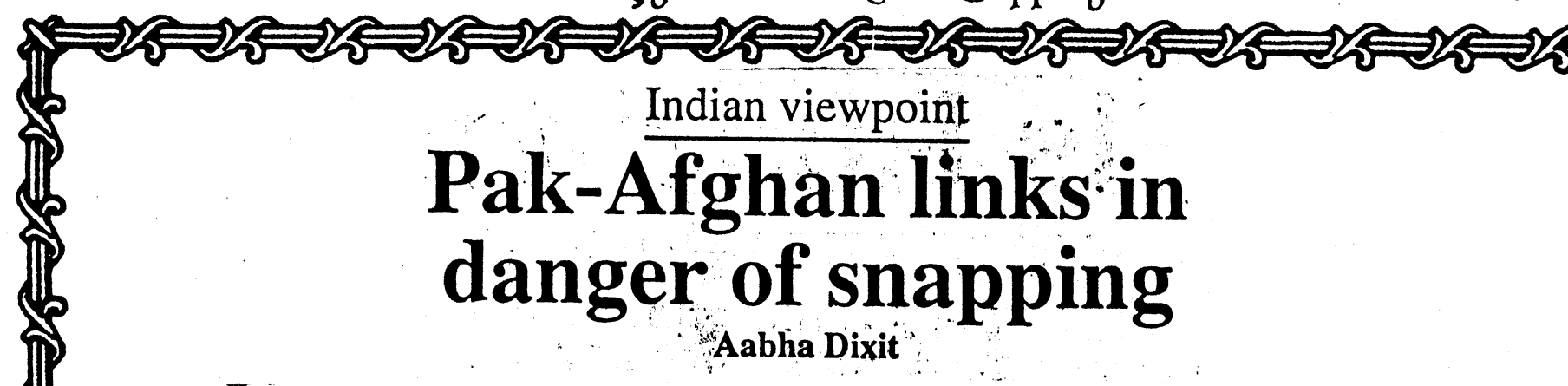

After years of playing with fire, Islamabad's mujahideen connection is beginning to suck it into the Afghan cauldron. A spate of unsavoury incidents recently have revealèd that the expected Afghan backlash is under way. The hijacking incident in Peshawar followed by a mob attack on the Pakistan embassy in Kabul have pushed Pak-Afghan relations to a new low.

Ever, since the Soviets left, there has been a deep divide within the Islamabad establishment over its Afghan policy. The hardline elements continue to uphold the line that the Soviet vacation of the country was merely one phase in the jihad they had launched, whose logical conclusion was to place a pliant government in Kabul. This government would maintain a special relationship with Pakistan and end support to the Pakhtunistan movement by accepting the Durand Line as the international boundary. Towards this ambitious policy, the $\mathrm{Zia}$ regime. cultivated Gulbaddin Hekmatyar, who appeared the most uncompromising mujahid.

2 Self-serving intent: By putting all its eggs into the Hekmatyar basket, Islamabad virtually closed all its options to become an honest broker in the post-Najibullah scenario. The failure to remove the element of mistrust that characterised the other mujahideen groups' response to Islamabad led the establishment in 1992 to try and change its tracks. But this came too late for other mujahideen leaders not to see through its self-serving intent.

Secondly, Islamabad took the decision to "ditch" Hekmatyar when a power struggle among the numerous groups for the control of Kabul had already broken out. Most importantly, while Islamabad officially severed its ties with Hekmatyar, several institutions within the establishment, like the ISI and military intelligence, continued to maintain their links with him.

Through the civil war, Islamabad has been consigned to the margins, with a marked inability to bring all the warring factions into a government of national reconciliation. Several attempts, including the Islamabad, Peshawar and Jalalabad accords, broke down, with Pakistan continuing struggle with a monumental refugee problem.

Having provided shelter to over three million Afghans during the 1980s, the deleterious effects of covert destabilisation were beginning to be noticeable inside the

country. Afghans were given the opportunity to own property and conduct businesses. Through the 1980s, the economy of NWFP and Balochistan was dominated by drugs and arms smuggling. A close nexus between local politicians and Afghan mercenaries saw spectacular increases in sectarian and ethnic violence throughout Pakistan.

Clear policy: The first signs of a clear policy of delinking from Kabul became evident in Ms Bhutto's second term. By symbolically closing the gates at Torkham, she tried to move cautiously in attempting to stop the

\section{ERONTIER POST}

10 APR 1994 free flow of refugees across the "open" border.

The closure of the supply lines meant a direct disadvantage to mujahideen groups with bases inside Pakistan. While Masood, Dostam had built up an organisation in the northern areas, Abdul Rashid Dostam is reported to have maintained cross border contacts in Uzbekistan. The biggest loser from increased Pakistani military presence along the Durand Line was Hekmatyar, whose strategic reserves continued to remain in NWFP. In retaliation, Hekmatyar refused to allow food convoys from Peshawar.to reach Kabul.

As Kabul was battered by the worst-ever fighting, that left over 1,000 dead and 12,000 injured, the non-supply of food and essential items provoked an instant attack by three Afghans who commandeered a school bus in Peshawar, taking eighty children hostage. Although the hijackers were killed, it was evident that ordinary Afghans equated $\mathrm{Mr}$ Hekmatyar with Islamabad.

Kabul and Islamabad retorted with sharp diplomatic missives, with the latter seeking to implicate the Indian intelligence agency for the bus hijacking. But subsequent events in Kabul gave lie to the conspiracy theory and revealed the pent-up feelings that Afghans harboured lowards Pakistan. Three hundred men stormed the Pakistani embassy in Kabul while the foreign minister, Assef Ali, was negotiating a new peace deal with Rabbani.

But Afghan opinion is increasingly veering around to the perception that Islamabad's self-serving policies are to be blamed in large measure for preventing Afghanistan's return to normalcy. As the war of words between the two countries escalates, there are many in Islamabad who are loudly protesting the inability of the Afghans to be "grateful" and have been demanding that the Afghans be reminded that their only supply ines come from the south.-The Times of India 


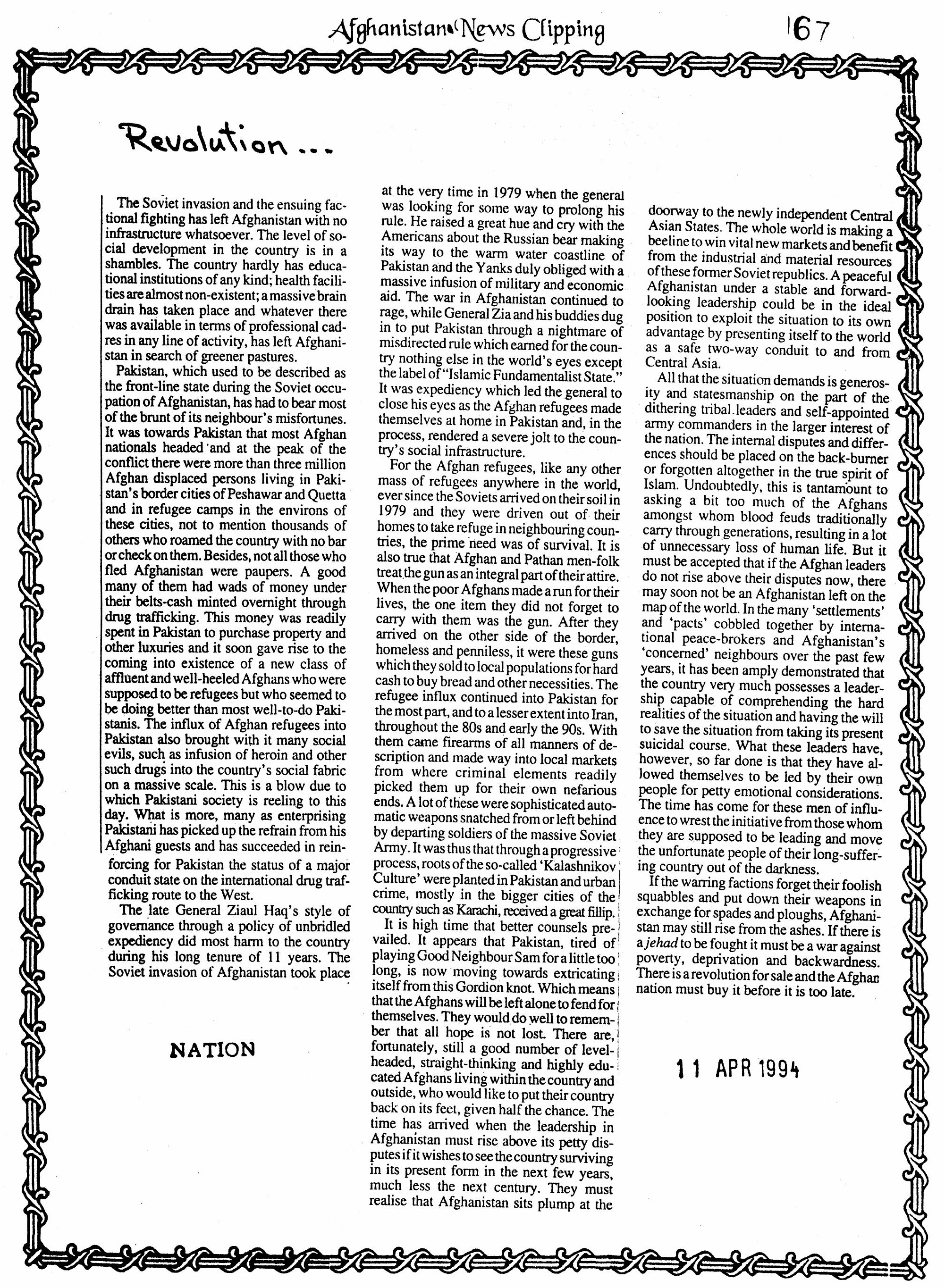


THE bitter truth is that the Afghan leaders who have been locked in a bloody conflict for quite some time now are not interested in peace. They feel no guilt about the enormous suffering and sorrows they are inflicting on the innocent civilians in mad pursuit of their lust for power. A fragile cease firc ivhich had been enforced at llie: start of this month to (liable a UN envoy to visit K.lbul was shattered on llunday as heavy artillery bomh.urdme'nt erupted in Kabul killing 20 people. The outbreak of hostilities will dampen the few peace initiatives that have been floating around. It is pittent that the people of Afghanistan, but not the leaders, have grown weary of the senseléss nar and want peace. Having inanaged to collect quite a hig arsenal, the warlords alle ungitging in a destruc. tive battle for power and would not stop) until one or the other has decisively humbled his rivals.

It has clearly emerged from the UN envoy's mediatory exercise in Kabul that a modus vivendi can be worked out to put a halt to the war only if the principal belligerents agree to step down. In fact, this is now being widely realised that as long as President Rabbani and Prime Minister Hekmatyar do not make their exit from the scene, Afghanistan can have no peace. They have been so rigid and uncompromising in their stance and the animosity they are displaying towards each other runs so deep that it would be impossible to devise a power-sharing arrangement in which both are to be accommodated, even if it is to be of an interim nature. Hence, all the schemes that are being floated by various intermediaries envisage an administration for Afghanistan without the inclusion of the two major contenders for power. If President Rabbani and Prime Minister Hekmatyar have the interest of their country truly at heart, they "should voluntarily step down to make way for an interim set-up acceptable to all major factions and tribes.

The details of such an arrangement should not be too difficult to work out once the personal drive for power by the key leaders comes to an end. There has been talk of a Loya Jirga being called to set up an interim government headed by the ex-monarch, Zahir Shah, who has been living a life in exile in Rome. The UN mediator, Mr Mehmud Mesteri, who has been meeting all sections of opinion in the country, feels confident about his ability to draw up an acceptable scheme for a broad-based interim government for Afghanistan. But the ground must be paved for it by inducting into power people who do not have a vested interest in promoting military confrontation, as the present incumbents are doing. Mr Mesteri must have had this in mind when he recently said that the Afghans will have to find a solution to their problems themselves.

It is now 14 years that Afghanistan has been in the grip of a brutal war. At one time it was believed that the withdrawal of the Soviets from the country would restore the status quo ante. This has not hap pened. What is worse, the guerrillas who amassed arms ostensibly to fight the Russians are now fighting each other and destroying the country in the process. It is beyond belief that these so-called leaders do not recognise the need for peace for their war-ravaged country. Their lack of concern for human life and suffering is astonishing. Above all, their leadership credentials are very much to be doubted, given their failure to understand the implications of continued hos tilities for the geo-political stability of the region. Afghanistan needs leaders who value peace and are willing to stop the war and start the work of rebuilding the country in right earnest.
THE NEWS INTE?NATIONAK Mr Mehmoud Mestiri, articulated some home truths when he called for an end to the flow of foreign money to the Afghan warlords. This was? coupled with his observation that President Burhanuddin Rabbani, Prime Minister Gulbadin Hekmatyar and Uzbek warlord Rashid Dostum were fighting for power. Other important points he made were that the people favour UN involvement and that there was widespread support for convening a Loya Jirga.

Well-wishers of that unfortunate country and of peace in general will fully endorse Mr Mestiri's views as what he said has frequently been emphasised as the only way to end the meaningless bloodshed. The conflict in Afghanistan since the very beginning never really made sense except that it served the interests of certain foreign powers. Its continuation, despite the apocryphal "liberation", is even more devoid of reason.

If acquisition of power is the only aim, then even that can be fought for within certain accepted rules which will? atleast save the civilians and the country from the rigours of conflict. But it seems that the strategy of the warlords calls for relentless killings and destruction as a means of forcing? the other side to its knees. It is a doomsday scenario and one that is $n c^{+}$impossible given the capacity of the opponents to maintain the tempo of battle at the highest pitch.

The Mestiri mission, which is continuing its consultations, in a way has already served an important purpose, in that it is pushing the Afghan issue into international focus. Till now, involvement by the UN was largely confined to providing essential food and medical aid and help in clearing the mines. Peace brokering was mostly done by Pakistan and a few other nations and the OIC. The former also continues to bear most of the burden of the human fallout of the civil war in the shape of refugees, whose flow continues.

It can be hoped that given the peace mediator's realistic appraisal of the situation, the future approach of the UN will be commensurate with the needs of the situation. A somewhat firmer direction has to be adopted, one which will aim at imposing an immediate ceasefire and then finding a solution. Confining the exercise of peacemaking to appeals and offers of package deals is not likely to succeed in a country where the holders of office are themselves inflicting violence on their people. This is an unprecedented situation and not much different from Somalia where a fight to overthrow a dictator dwindled into one of the major human tragedies of the recent times.

The people of Afghanistan deserve a life of peace and fulfilment. Their history, sadly, is not without times when they underwent long periods of unrest and destruction, but all that has changed over the last half century. The country has known peace and progress and in spite of its poor economy and lack of development, it symbolised stability in an area troubled by tension. It is unfortunate all that was lost due to the misguided ambitions of a few self-appointed leaders aided by foreign interests. 


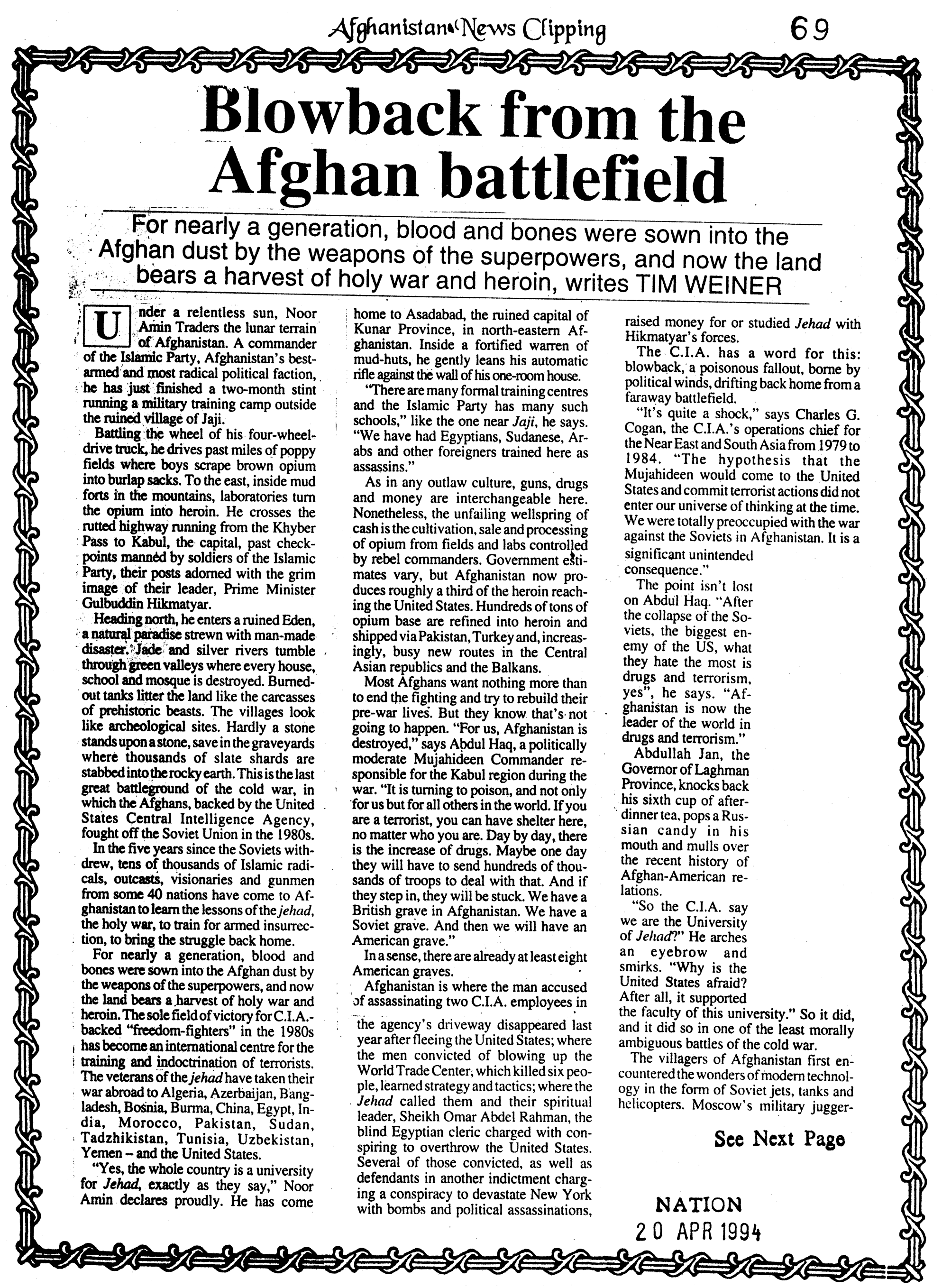


The Afghans took on the intidels. They
died in uncounted numbers. They lived on
stale bread and tea. They slept on stones in
the mountains. And they drove the Soviets
out. They fought their holy war with
roughly \$6 billion in weapons and mate-
rial from the C.I.A., Saudi Arabia and an
odd alliance of Iranian weapons procur-
ers, Arab princes, Egyptian politicians and
Chinese Generals. Together, the Afghans
achieved a famous victory. Some say it
was the beginning of the end of the Soviet
Union.

"But the people of Afghanistan, we have gone from one jail into another jail", says Abdul Hakim Katawazi, commander of the state police under the last King of Afghanistan in the early 1970's.

The prison guards are a God-mad rabble, the foot soldiers of a new Islamic order who received their advanced training in Jehad in the military camps that now dot the countryside. Roughly 20 such centres exist in eastern Afghanistan between $\mathrm{Ka}$ bul and the Khyber Pass, mostly under the control of Hikmatyar and his commanders. The camps have grown up around abandoned villages and battered Soviet military garrisons. Sacks of flour, some purloined from donations by the United States Agency for International Development, are stacked like sandbags in simple huts. Weapons, a good many of them taken from C.I.A.-supplied caches hoarded during the Jehad are plentiful.

In these training centres, the foreigners learn about guerrilla warfare, anti-aircraft weapons and rocket-propelled grenades. Much in demand, but too precious to fire in training, is the Stinger anti-aircraft missile, supplied by the hundreds to the Afghans by the C.I.A. in the 1980's. An unknown number are missing and unaccounted for; the C.I.A. is spending $\$ 65$ million trying to buy them back.

The men fly tothe bustling frontier town of Peshawar, Pakistan, to the east, riding buses or trucks over the Khyber Pass to Jalalabad, in Afghanistan. The provincial capital serves as a way station for the new arrivals heading for the camps. Here are Palestinians exiled from their native land; cashiered Egyptian army officers; Moroccans, Algerians and Sudanese intent on bringing down their Governments, and from time to time, Americans from New York, Detroit, Chicago and other cities.

The Afghans who lead the training, like Noor Amin, are in high demand wherever thousands into squalid refugee camps, created political chaos and blocked millions of exiles from returning.

Hikmatyar's weapons, the source of his ministry, come mainly from the enormous arsenal sent by the C.I.A. The United States and its allies gave him more than $\$ 1$ billion in armaments: tens of thousands of assault rifles and rocket-propelled gre- radical Islam is at war, for their victory was the first triumph of Islamic warriors over an infidel army since the 16th century. "Their Jehad credentials, religious and political, are impeccable," says an American intelligence official. "They beat one of the world's two superpowers and now they're working on the second."

The Dean of the university of Jehad, Gulbeddin Hikmatyar, represents almost everything Americans hate, fear and misapprehend about radical Islam. The feeling appears to be mutual.

Talking with Hikmatyar is like listening to wind chimes tinkiing on the porch of a burning building. A disarmingly feline man, he purses his lips and talks dispassionately of the death of millions. His aim is to build "a true Islamic republic," under

nades, millions of rounds of ammunition, hundreds of the deadly accurate Stinger missiles. Hikmatyar put away enough weapons to make war for four more years.

No one doubts he will. Hikmatyar's Jehad never ended. When he speaks of a true Islamic republic, he means a land without borders.

By the time the Soviets left Afghanistan in February 1989, thousands of Afghantrained volunteers were ready to carry on the war abroad. Thousands more took their place in the camps

The militants took the torch of the Afghan rebels' holy rage and turned their energies to a greater battle. They saw the 1991 Persian Gulf war as a modern manifestation of the medieval Crusades, the Arab nations supporting the war as corrupt

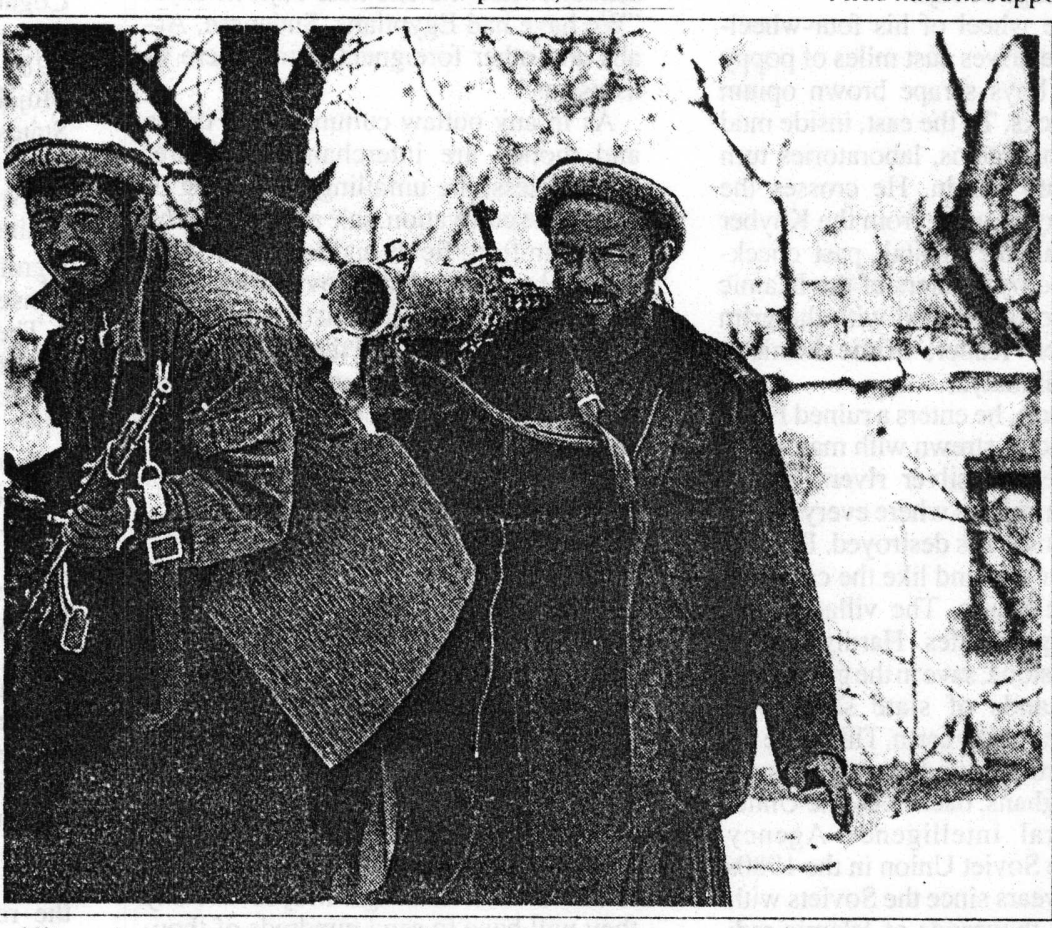

Hikmatyar's men regularly fire artillery shells and rockets into Kabul collaborators with Christendom and the United States and the United Nations as imperial knights with smart bombs. Their anger was focused on Arab leaders they saw as American agents, and on America itself. To the north lay Tadzhikistan and $\mathrm{Uz}$ b e k i s t a $\mathrm{n}$. Tadzhiks and Uzbeks by the millions live in Afghanistan; tens of millions of their Muslim brothers live in the former Soviet republics. Some 20,000 people have died and a half-million have been forced from their homes as Islamic rebels battle the pro-Communist regime still in control of Tadzhikistan. Russia still has thousands of soldiers stationed his dominion, and he has the will and the weapons to fulfil that dream. If it takes another generation of war, so be it.

"We have already had one and a half million martyrs," Hikmatyar said in a 1992 interview. "We are ready to offer as many to establish a true Islamic republic. We are ready to remain in the mountains for another 14 years."

Unique among the world's Prime Ministers, Hikmatyar has spent the past 22 months firing artillery shells and rockets into the capital of his own country. This act of political sadomasochism began the week the rebels took Kabul from the Soviet-backed regime. The barrage is aimed at the citizens of Kabul, whom Hikmatyar considers to have collaborated with the Soviet occupation, and at the armed forces loyal to Afghanistan's President, Burhanuddin Rabbani. It has killed more than 10,000 Afghans, driven hundreds of there, fighting guerrillas on both sides of
the Afghan border. The President of Uzbekistan, Islam Karimov, says he expects the rebels to attack his country and Tadzhikistan this spring.

To the east, hundreds of Afghans allied with Hikmatyar have fought in the embattled state of Jammu and Kashmir, a territory disputed since the 1947 partition of ) India and Pakistan. Thousands have died in the struggle. In China, where Islam has been periodically suppressed Afghan veterans have fought in two western provinces, Uighur and Xinjiang, where they have armed and trained Chinese Muslim rebels.

See Next Page 


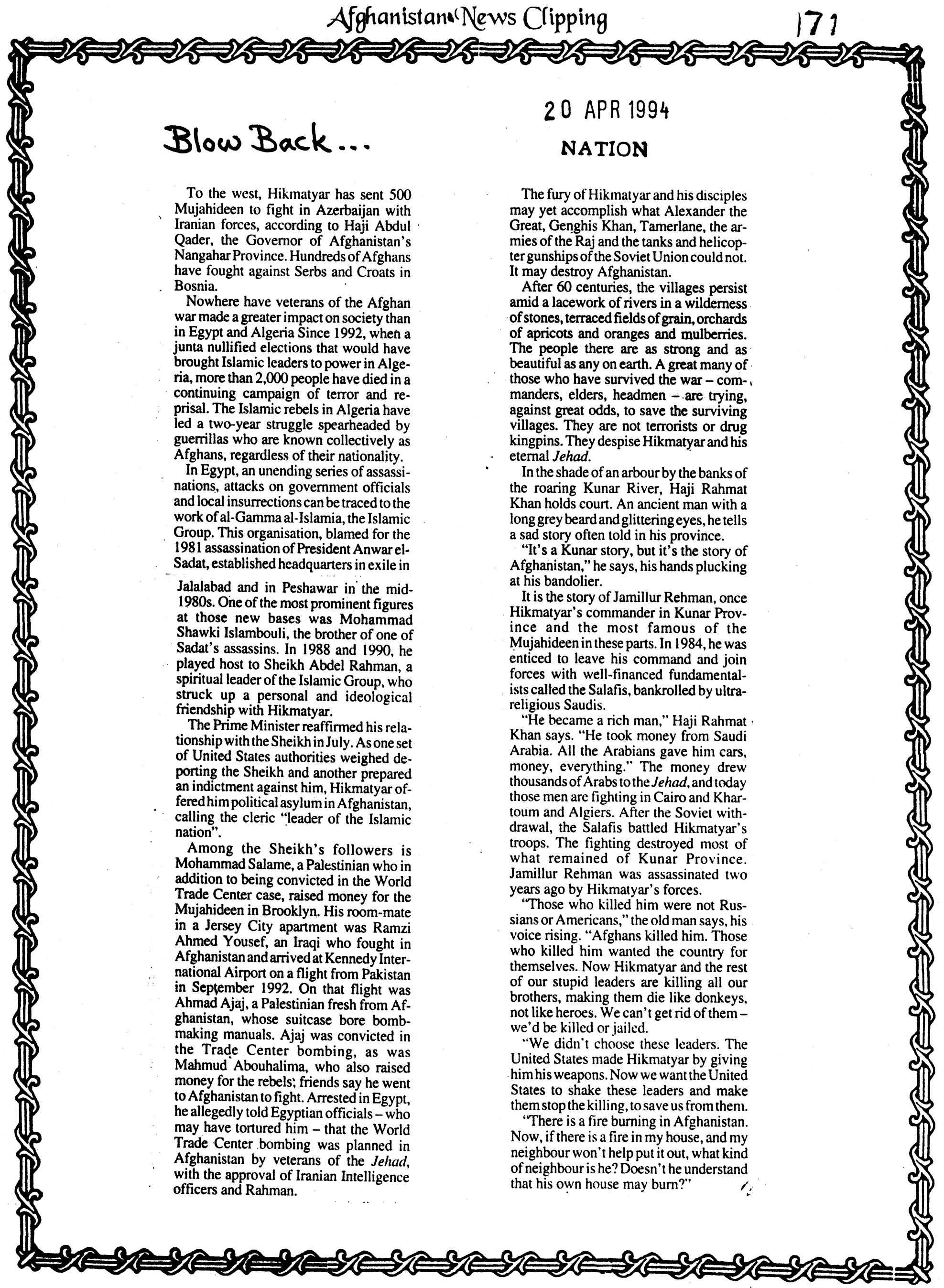




\section{Afghanistan for the future \\ ERONTIER POST} - Groping t

The monith of April, which heralds spring in most parts of the world, has come to symbolise a dark season of death and destruction for Afghans. The Leftist military coup which overthrew the government of Sardar Mohammad Daood took place on April 27, 1978. The civil war, that followed it, started the vicious cycle of horrible violence which continues to this day. The conflict got internationalised and led to the Soviet military intervention, Afghan resistance to the intervention and to Afghanistan becoming a focal point in the East-West politico-military confrontation at the peak of Cold War.

Again, it was on April 15. 1992, after the Soviet withdrawal, that a military coup disrupted the UN-sponsored peace process, which had promised a peaceful transfer of power from the government of Dr Najibullah to an interim arrangement as a prelude to a broad-based and representative government. In the following two years, after the so-called victory of jihad, Afghanistan has not scen, in any manner, contraction of anarchy, civil war and bloodshed or the expansion of peace, stability or reconstruction. In fact, the situation has gone for bad to worse.

Kabul, the heart of Afghanistan, is literally torn apart by constant and intensive acrial bombardment, tank shelling, rockets and the massive use of all sort of dangerous and sophisticated weapons by the forces of different Afghan war-lords. Kabul has seen the kind of savage brutality and destruction which was not experienced even under the attacks of wild hoards of barbarian invaders of the ancient past.

The thunder of applause. emanating from West for Afghans for defeating the "evil empire", has died down and is replaced by the most despicable conspiracy of silence. After bleeding the Soviets white, the Western project has come to an end and the file is duly closed. The present-day Afghanistan, with all its dreadful

\section{Afrasiyab Khattak}

agonies, does not exist as far as the civilised and human rightsconscious West is concerned. The Western media that used to be religiously punctual in reporting every minor or major incident in Afghanistan, real or fabricated, is criminally silent over the massive carnage in Kabul and the sufferings of common and innocent Afghans.

"The new world order" has yet to discover the disorder which has turned life hell for Afghans, a disorder imposed on Afghans from abroad by the neighbouring countries and the big powers. Running

\begin{abstract}
Afghan tragedy. Right from its emergence in 1747, Afghanistan was a commonwealth of tribes. ruled by tribal aristocracy which had carved out the statc of Afghanistan (later Durrani Afghan empire) on the ruins of the Mughal empires. The primitive economy and very strong tribal socio-cultural structure, in which there was no tradition of tax-paying and in which the unruly tribes were vigilant and sensitive about their autonomy, the evolution of a modern and elaborate state structure was a difficult and complicated process.
\end{abstract}

This destructive politico-military conflict not only inflicted large-scale human and material losses on Afghanistan, it also led

to further fragmentation of the Afghan tribal society. Ethnicity was injected in an exaggerated way under the Soviets (as part of the 'Sovietisation' policy) in the Afghan socio-political life and localism reached its height under the narrow and clan-based commanders. A very logical question which comes to mind is: In spite of heroic sacrifices, why couldn't the Afghan resistance throw up a popular leadership which could rally the majority of Afghans?

for their lives from the war, which is being fed by the dumps lefi behind by Russians and Americans, Afghan refugecs have discovered, to their hotror, that their status has changed from refugees 10 just "displaced persons" and that they shall be dealt accordingly. Another equally unpleasant discovery is the fact that after the withdrawal of the Soviet military machine and with the end of the biggest covert operation of the American CIA after Vietnam, "the Islamic solidarity" of the ncighbouring Muslim countries is cvaporating and Afghans are turning into an undesirable liability for them.

There are many internal and external factors responsible for the
In view of the extreme dearth of internal economic resources, developinent and consolidation of the Afghan tribal state depended on its capacity to expand and draw on resources outside its nucleus.

This is what happened under Ahmad Shah Abdali, the founder of Afyhanistan in the second half of the 18th entury. But in the 19th century, Afghanistan found itself sandwiched between the Czarist Russian empirc, expanding from the North, and the British empire, expanding from the South. During most of the $19 \mathrm{th}$ and 20 th centurics, Afghanistan had to live under the siege of big powers. The external colonial pressure, which at times turned into temporary colonial occupa- tion, and the internal turmoil of the rebellious tribes who were coming under growing economic squecze led to the decline and shrinking of Afghanistan to its present borders. The Pukhtoons (Afghans) who constituted the nucleus of Afghanistan were divided with the colonial demarcation of the region.

In early 20th century, when the status of a buffer zone was formal- 1 ly imposed on Afghanistan after the Russo-British understanding of 1907 - turning Afghanistan a non-conductor, politically - the watchful eyes of the mutually hostile superpowers checked and controlled every social, administrative and political development. The modernist reforms of patriotic and independent-minded King Amanullah Khan were regarded dangerous by the British empire and they encouraged the efforts to overthrow him. Nadir Shah and Zahir Shah were more cautious and they perfected the policy of $\mathrm{a}$ "tight-rope-walking".

Apart from using most of its energy in a balancing act between superpowers, the Afghan government remained comparatively isolated due to border dispute with Pakistan and mistrust of Iran. Afghanistan remained socially and politically dormant under the rule of Zahir Shah for most of the time. But the failure in building modern social and political institutions led to the absence of a medium for peaceful and smooth changes. An expcriment with introducing a rudimentary type of democracy in late sixties did not take off, and military coups in Kabul became the only means of bringing about social and political changes.

Lacking the expcrience of political activities on large scale, the Alghan intelligentsia, which was concentrated in Kabul and some other urban centres, could not develop political organisations with popular basis, particularly in rural areas. Although quite sophisticated in academic activities, this intelligentsia remained naive as far as political practice is concerned. Living in a comparatively isolated. and backward buffer state, a part (Continued on Page 11) 


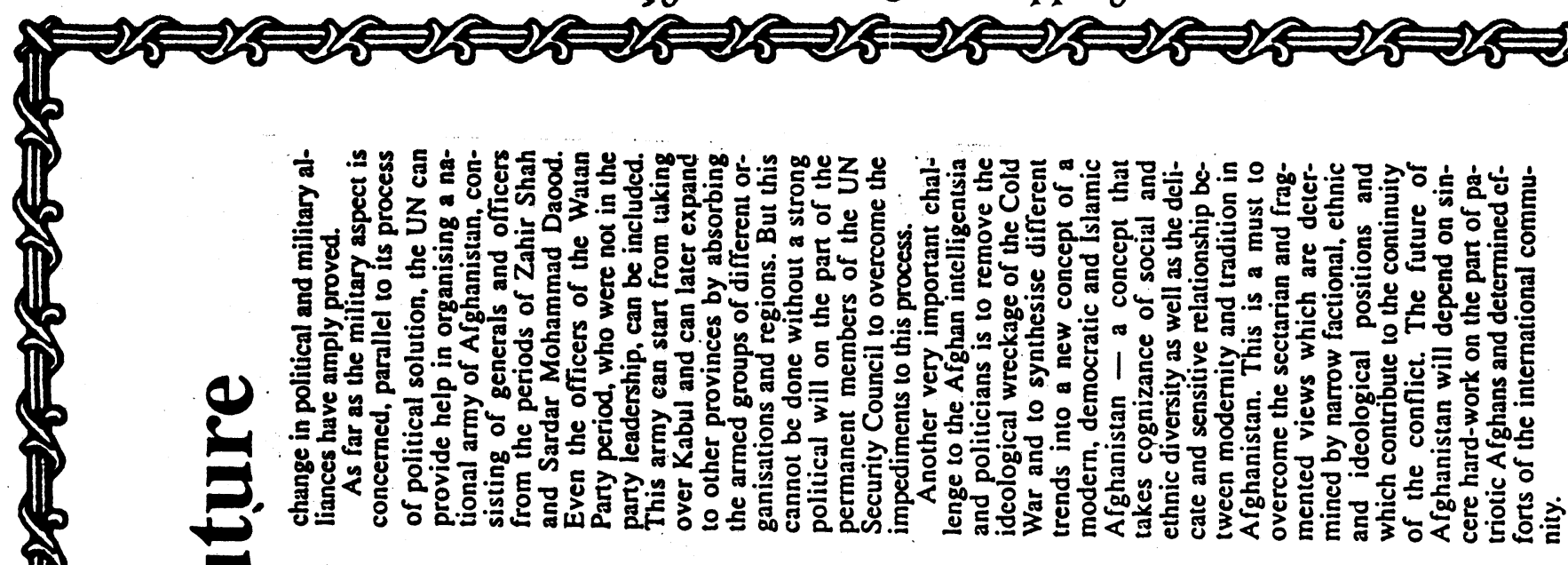

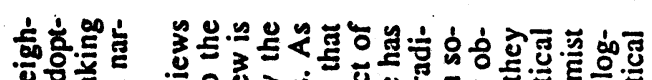

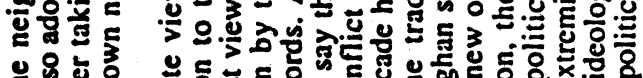

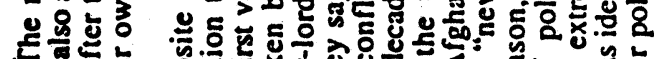
势 을.

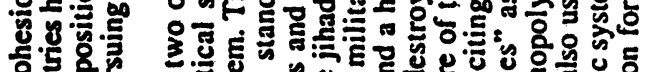
8

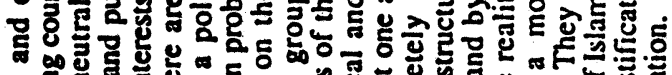

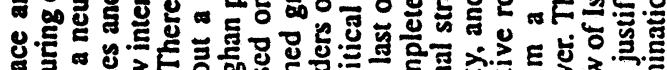

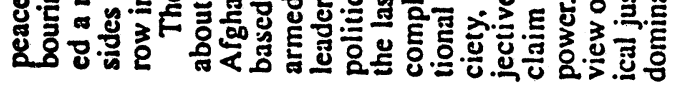

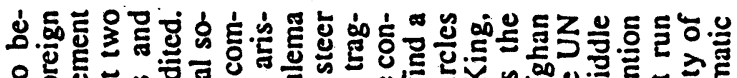

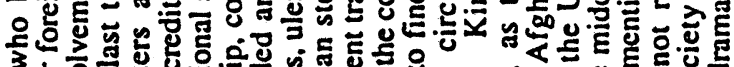

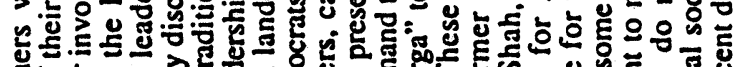

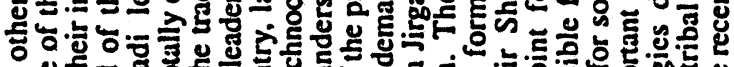

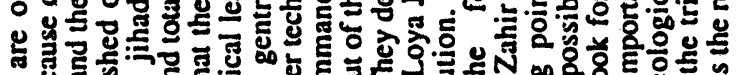

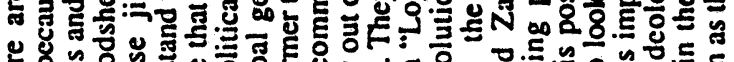

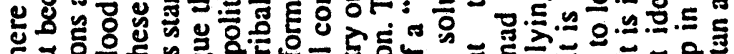

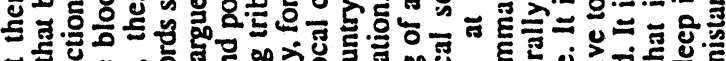

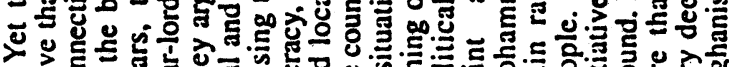

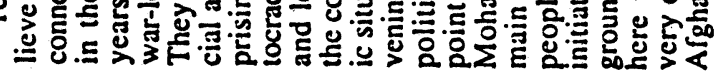

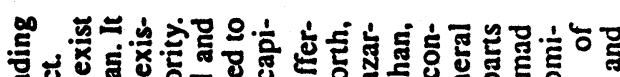

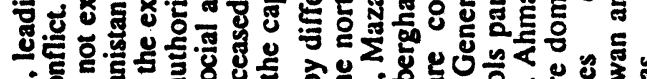

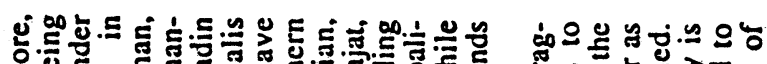

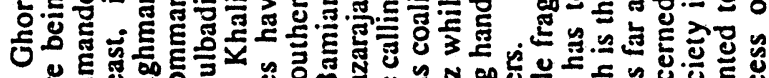

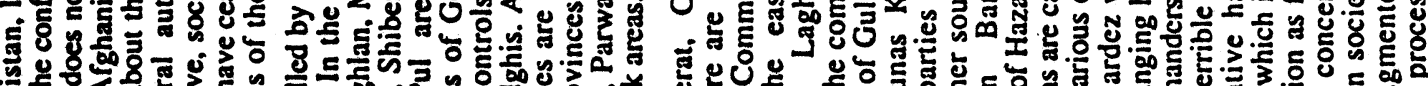

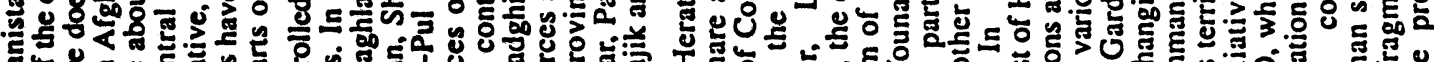

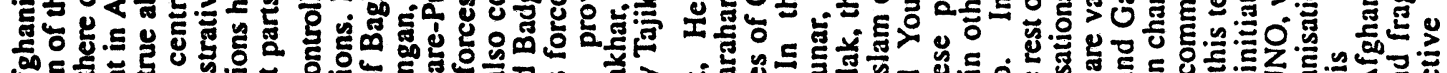

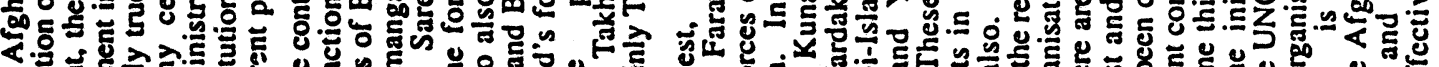

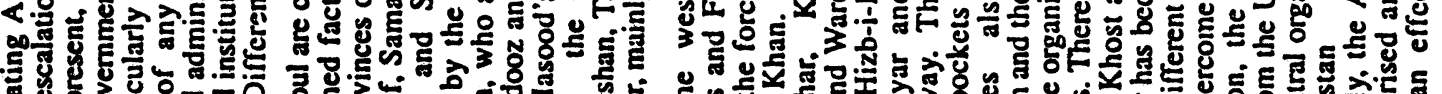

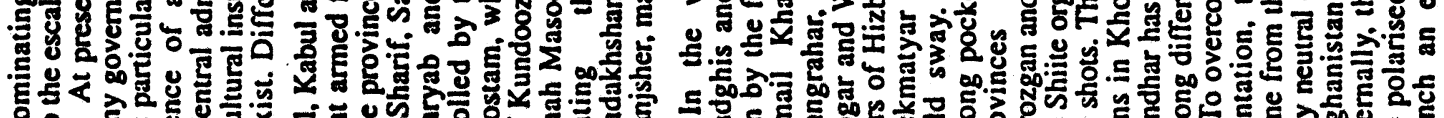

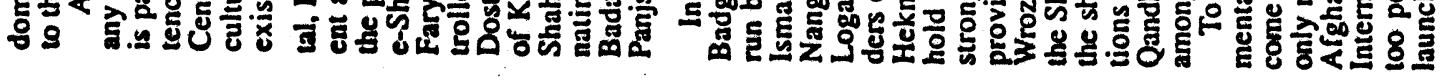

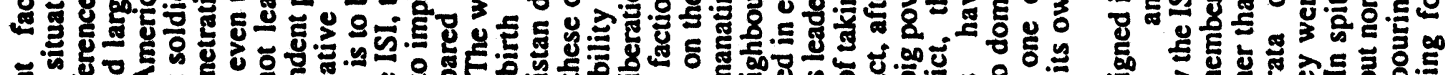

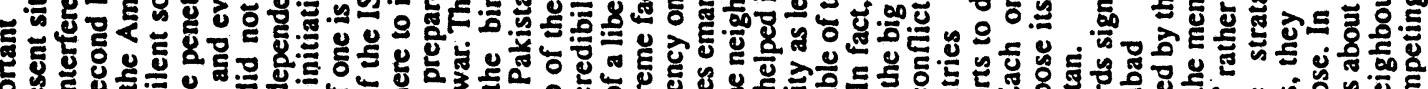

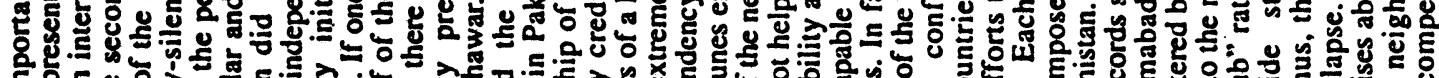

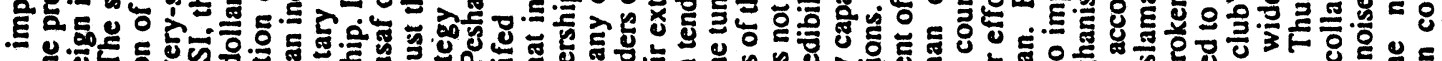
然 E.

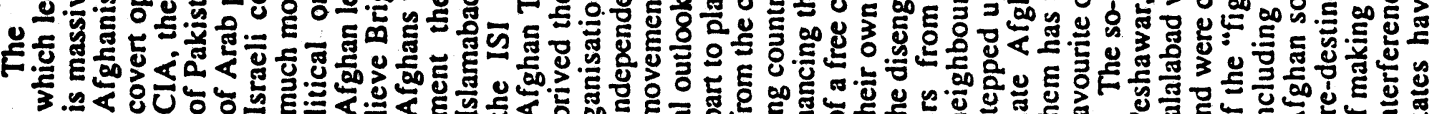

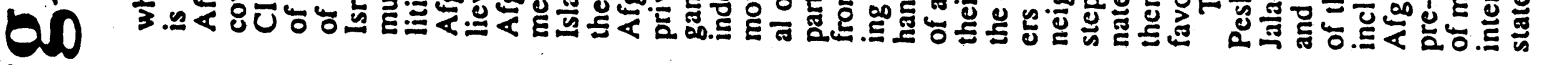

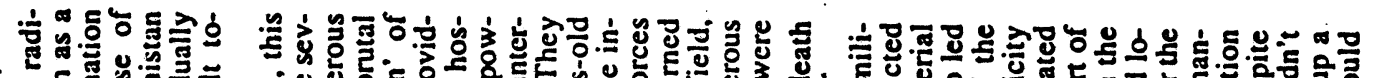
○ \$ 0.000 (5 马 E. 马

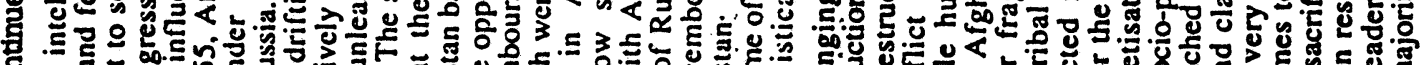

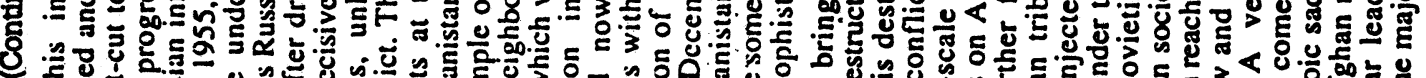

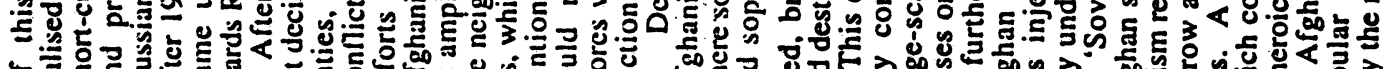
ठ 
THE horrendous dimensions of the calamity, brought on their own people by the feud. ing Afghan leaders, have prompted the special UN mis. sion's appeal to the world community for a fresh contribution of 62 million dollars in humanitarian assistance. The internecine warfare between the rival factions, led by President Burhanuddin Rab. bani and Premier Gulbadin Hikmatyar, has since January caused the death of an estimated 2,500 Afghans and injuries to 17,000 others. According to Sotiros Mousouris, UN Secretary-General's special envoy for Afghanistan, who appealed for the additional humanitarian funds on Wednesday, described the situation in Afghanistan as among the world's worst humanitarian crises. Food and essential medicines are among the supplies most urgently needed but aid convoys on their way to Afghanistan's interior are continually obstructed by treacherous ambushes and intermittent rocket firing.

Ironically, the destruction in Afghanistan in the past four months has been considerably worse than what the country had suffered during the years of Soviet occupation. Even more incongruously, the two Afghan factions which are at war today are led by Mujahideen leaders who fought on the same side against the Russians and now uccupy positions of the highest responsibility in the coalition government. Mousouris has also disclosed that the fighting during the past four months has made thousands more Afghan refugees. Pakistan is obliged to accept its share of the additional burden and hundreds of the refugees found their way into Karachi during past one month.

The Afghans' longing for peace was evident from the overwhelming reception which the UN-special peace envoy, Mahmoud Mestiri, received when he reached Mazar-i-Sharif last week. An Afghan lady teacher's pathetic appeal to Mestiri in Herat that the UN which left Afghanistan in the midst of a crisis in the past should not leave them in the lurch once again echoed the feelings of the multitude of her fellow countrymen and women. Mestiri is striving for a permanent ceasefire as a prelude to the return of normality to Afghanistan. His spokesman affirmed that there was a strong and widespread desire for peace among the common Afghans but regretted that their leaders apparently lacked the flexibility needed to achieve peace.

There may, however, be some hope in the fact that Mestiri has persisted with his mission and he would visit Tehran and Riyadh at the end of the month to mobilise their support for his efforts for restoration of peace in Afghanistan. In sheer desperation, a section of the Afghan leadership is even said to favour the return of ex-King Zahir Shah to replace the present government of the Mujahideen. There can, however, be no real possibility of peace so long as Rab. bani and Hikmatyar remain rigid in their ways and insist on impossible preconditions for agreeing to a peace process and their well-armed militias continue to engage in war of mutual destruction. 


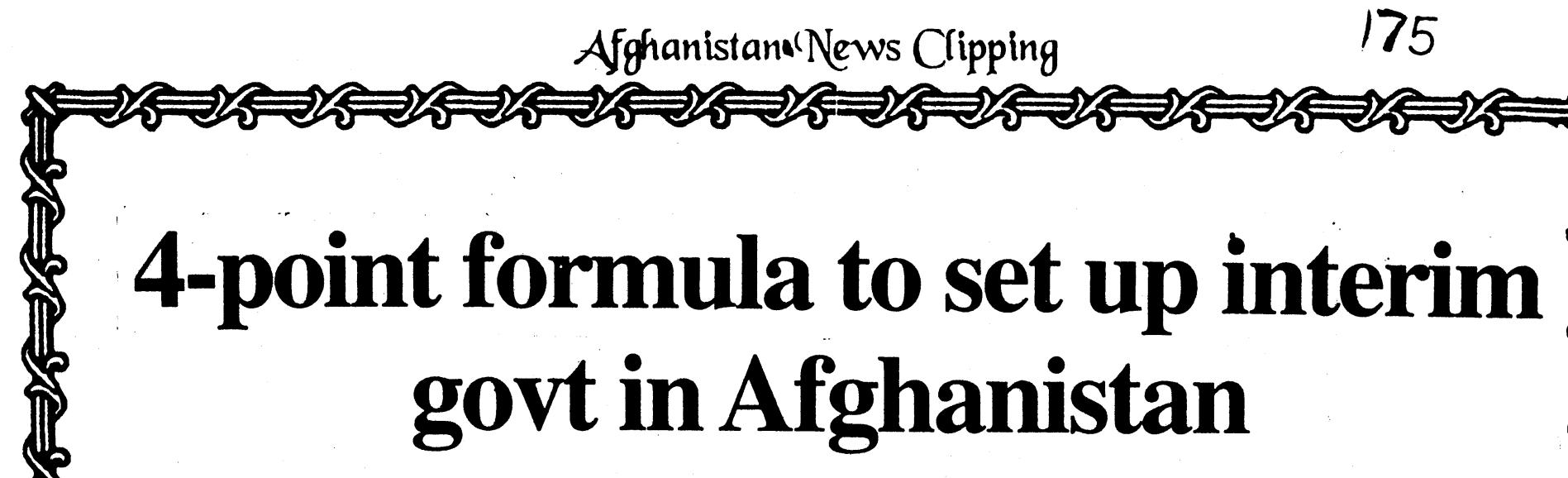

From Our Correspondent

PESHAWAR - Teachers of Kabul University and other educational institutions from various parts of Afghanistan have formed the Afghanistan Nationals Reconciliation Anjuman and in a bid to build up a consensus among the existing Afghan leadership, it has framed a fourpoint formula for an interim government which will hold general polls and will hand over power to the winners.

The four-point formula of the teachers community includes 1) Supreme leadership Shura, 2) cabinet, 3) armed forces Shura or body and 4) judiciary Shura. The interim government will comprise these four supreme bodies and it besides the restoration of peace, establish a centralised authority in Kabul and will frame a new Constitution for the country as well as would pave the ways for holding the general

polls. The teachers proposed that all civil, military and other officers including bureaucrats who had left Afghanistan or terminated from their services since 1978 will not only be reinstated but they would also be given a chance to play their due role in the efforts aimed at restoration of a peaceful atmosphere in their motherland.

The teachers community states that supreme leadership Shura will be considered big powér institution and till general polls and existance of parliament, its decision could be honoured with letter and spirit. The composition of the Shura is: 1) ten impartial but competent persons to be nominated by the United Nations after taking the Jehadic organisations in to confidene 2) one commander from each Jehadic force 3 ) heads of the armed forces and judiciary and a representative from each and every province to be introduced by the pro- vincial Shura's or to be named by majority of the people from the province concerned. The supreme body will elect one among them as their head with majority of votes. The fuctions of the supreme leadership Shura is 1) to form an interim government, to establish state organs and departments', formation of the government will include a Prime Minister and Ministers, 3) to nominate heads and members of the armed forces Shura 4) an end to illegal rules and regulations introduced by armed Mujahideen commanders and framing of a Constitution along with rules and regulations for each and every department 5) disarming the armed guards and handing over the arms and ammunition to the armed forces and 6) an end to emergency situation all over the country.

The cabinet of interim government should be comprised competent, capable and experienced people. The

cabinet will be responsible to the supreme leadership Shura and will take measures for the implementation of its decisions. The Prime Minister and ministers will be impartial and neutral persons. The Prime Minister in each and every step will take the leadership Shura in to confidence and will frame both internal and external policies as per proposals of the Supreme Leadership Shura. It will also focus its attention on formation of a police force for the restoration of peace and will nominate heads of various departments from neutral and capable dignities for an interim period. It will also convince the foreign donor agencies and NGO's to take part in rebuilding and reconstruction process of Afghanistan. The cabinet will also be responsible for making arrangements for general polls with the help and guidance of the United Nations. The cabinet after taking the Supreme Shura in to confidence will constitute an impartial and neutral army.

The Armed Forces Shura will compris 1) each known commander to be introduced by the Jehadic forces 2) ten impartial army officers who remained in the armed forces till 1978 and 3) three among the moderate, intellectuals and teachers who remained impartial since 1978 . The functions of the armed forces' Shura is to organise a national army with the wishes of the cabinet and Supreme Shura and nominate heads of various sub-departments and institutions.

It will also be responsible for disarming the people and restoration of peace and a centralised authority in Kabul. The members of the Armed Forces Shura will elect one among them as head of the Shura.

The Judiciary Shura will comprise neutral and honest people to be selected by the Supreme Shura and also

by the Jehadic and political forces. The body will introduce impartial judicial system in the country.

All these four bodies through mutual understanding will form a Loya Jirga with the help and supervision of the United Nations. The members of the proposed Loya Jirga should be neutral, competent and acceptable to the society. The functions of the proposed Loya Jirga will be similar to that of a Parliament or Senate as in developed democratic countries. Its decisions will be implemented by all the four institutions of the interim government and it will nomiante deputies and advisers for Prime Minister, Ministers, heads of the armed forces and chief justices. The Loya Jirga will frame a new Constitution, reflecting wishes and interests of the people and will help the government for establishing a centralised authority in Kabul as well as for the restoration of peace. 


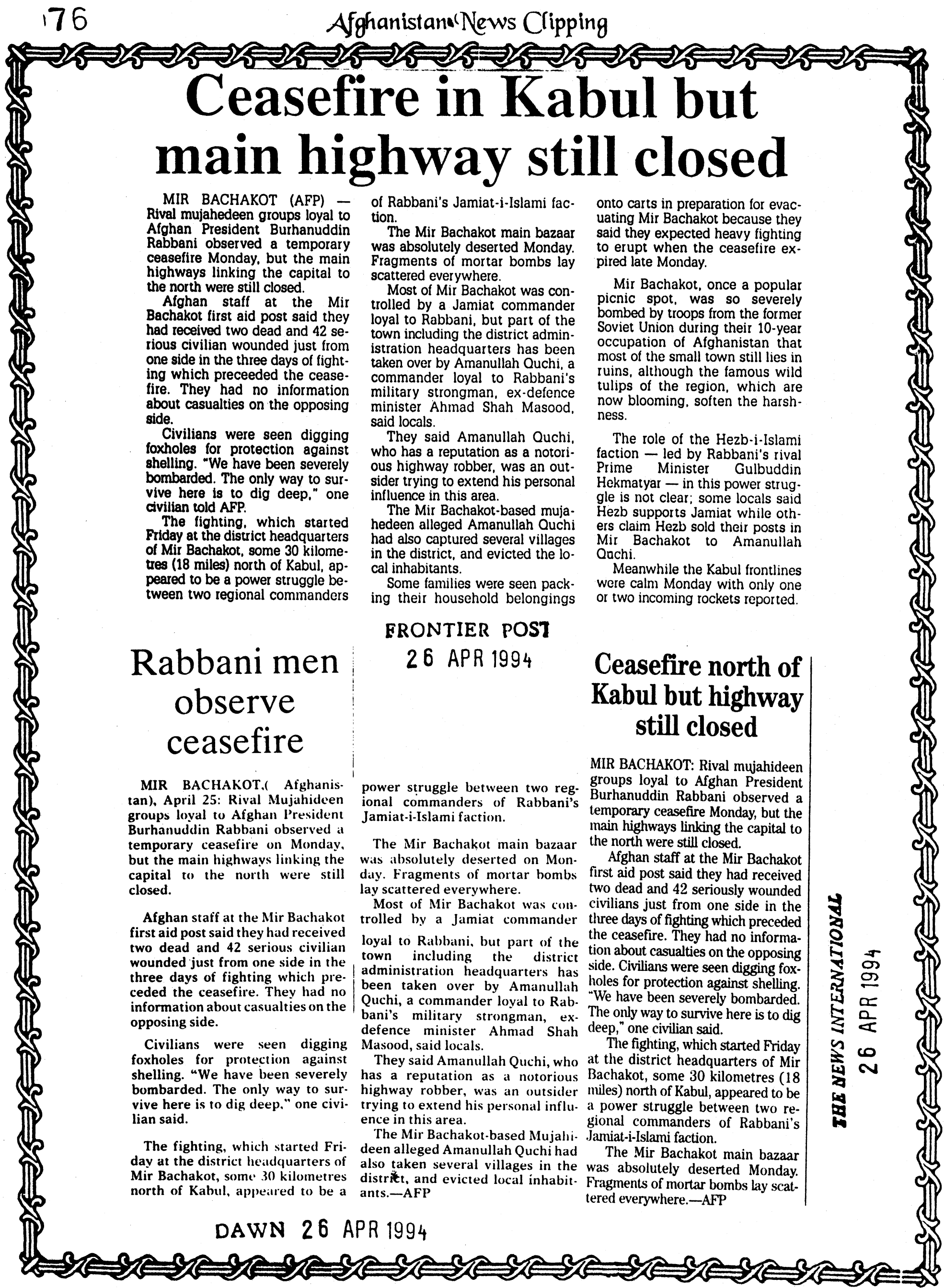




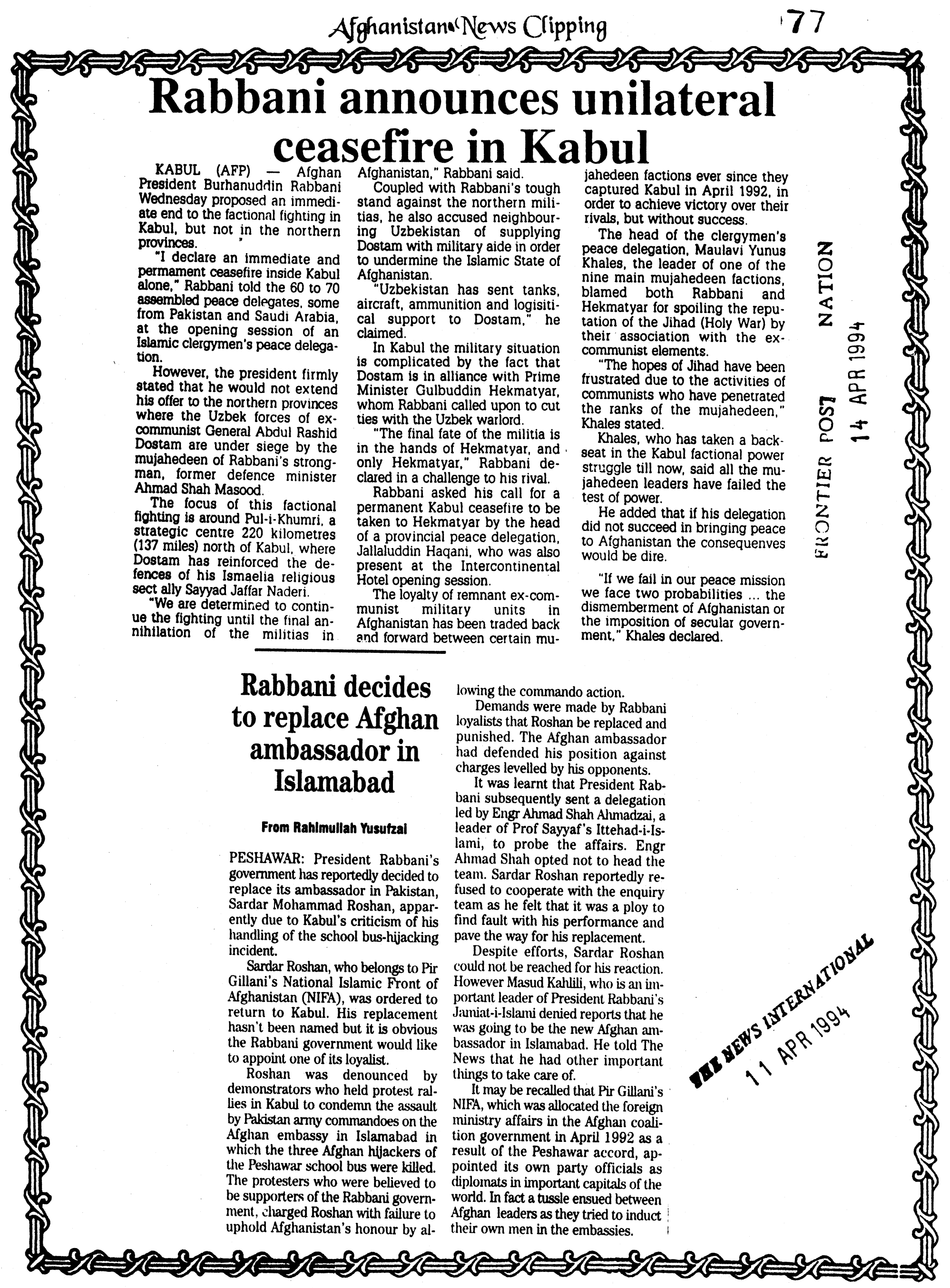



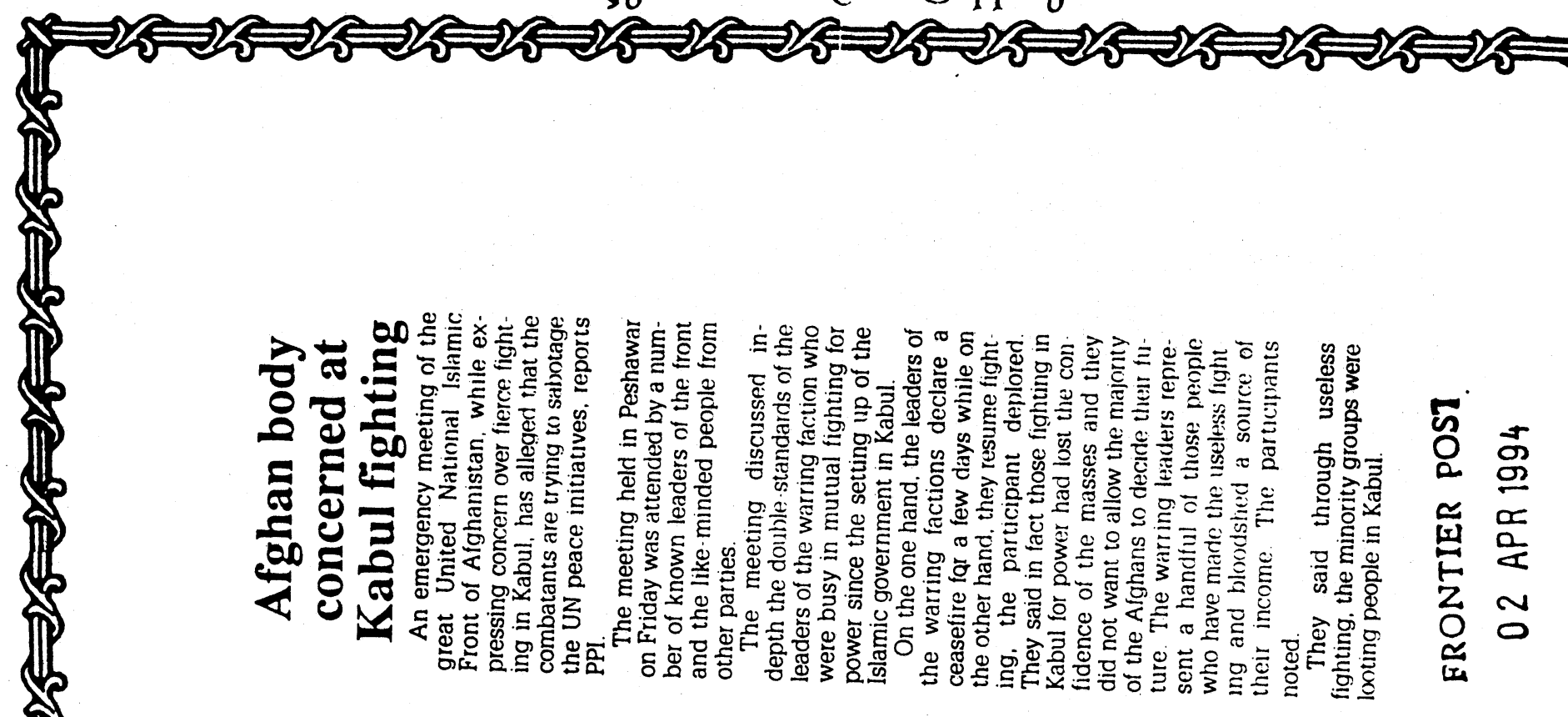

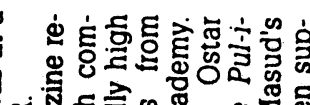

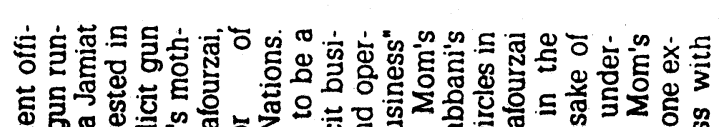
3.

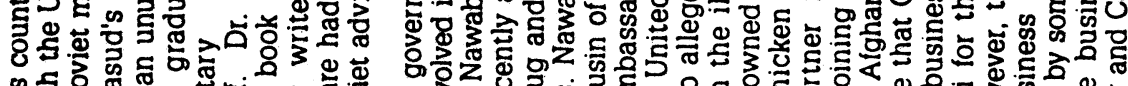

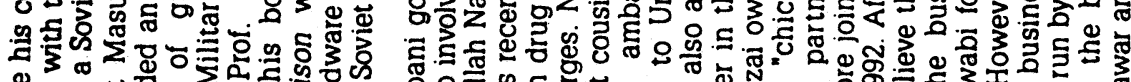

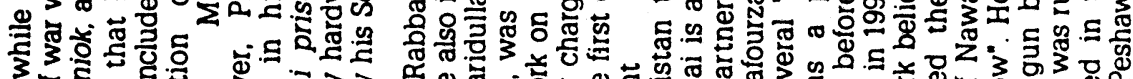
3.

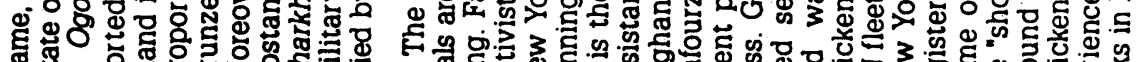

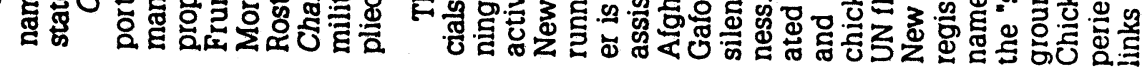

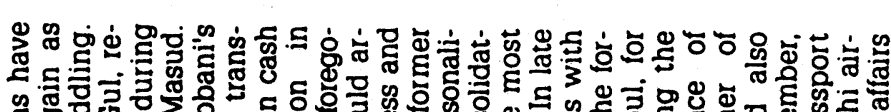

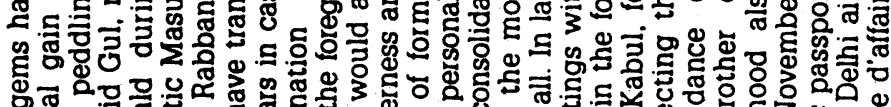
\$耳.

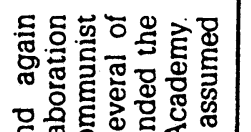
क

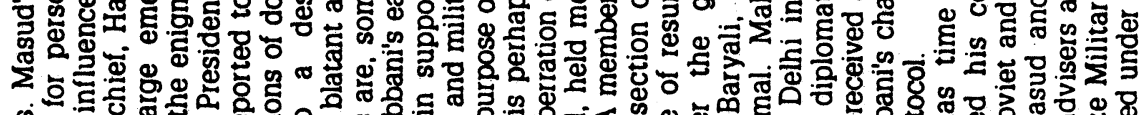

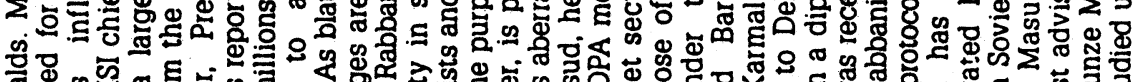

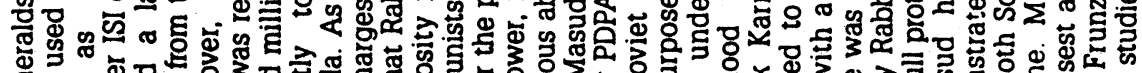

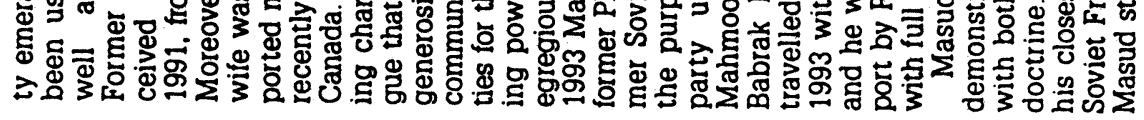

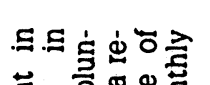

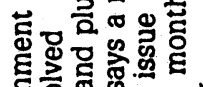

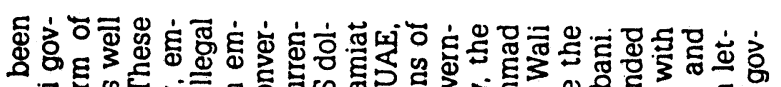

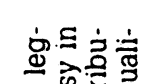

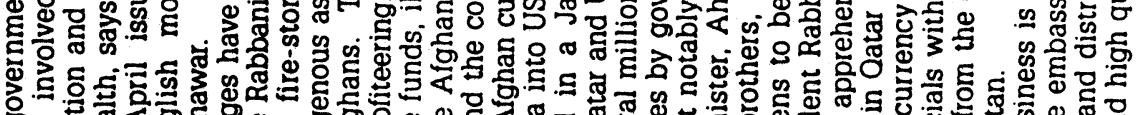

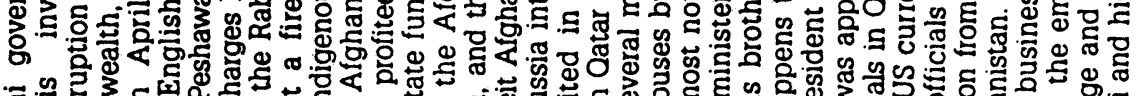
政

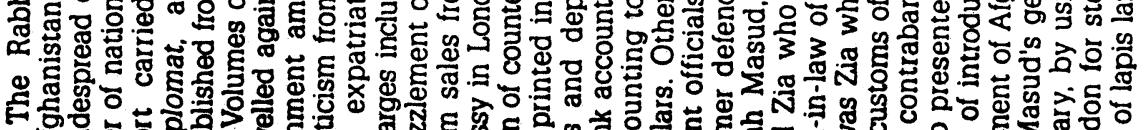

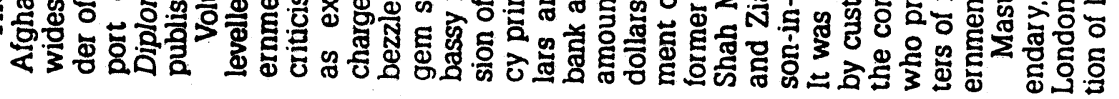

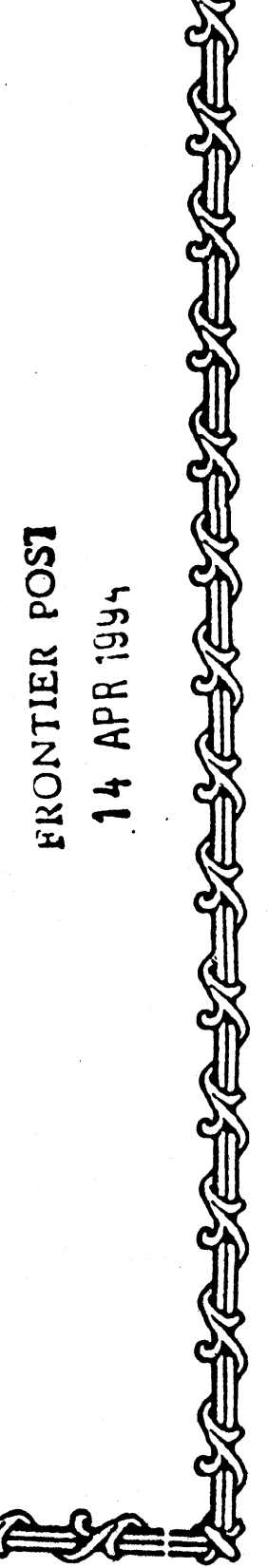




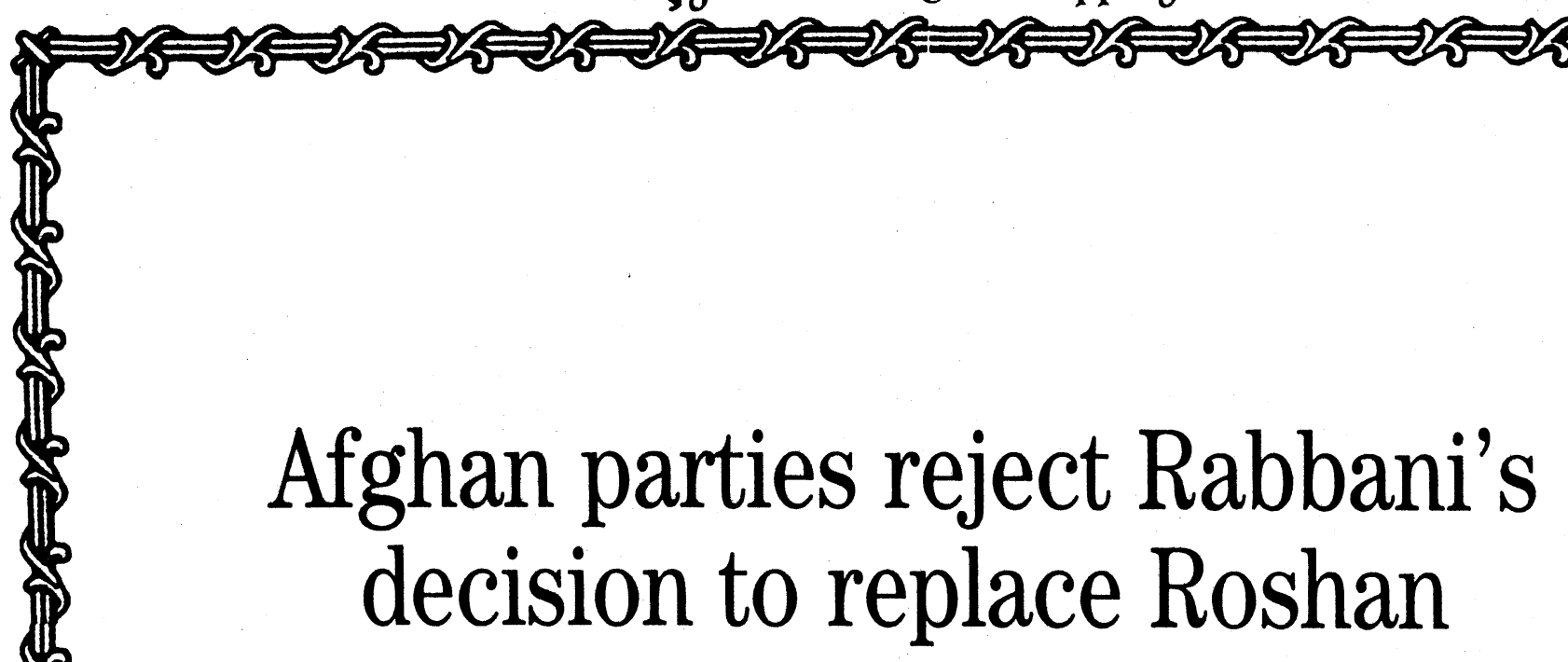

\section{Bureau Report}

PESHAWAR: Various Afghan parties have decided to resist the efforts of President Rabbani's government to replace Sardar Mohammad Roshan, Afghanistan's ambassador to Islamabad.

It was learnt that Pir Gillani's NIFA, to which Roshan belongs, as well as some other parties opposed to the Rabbani government, have rejected Kabul's decision to appoint another ambassador in his place. Prime Minister Gulbaddin Hekmatyar too was stated to be opposed to the move.

The Rabbani government decided to replace Roshan after receiving the report of an inquiry committee sent to Islamabad to probe the affairs of the Afghan embassy. Engineer Ahmad Shah Ahmadzai of Prof Sayyaf's Ittehad-e-Islami, named as head of the inquiry team, later withdrew from the probe. In his place a banker, Jawad, who is close to President Rabbani and was accused of some financial impropriety in the late 1980s, was appointed as head of the inquiry committee. Sources close to Roshan said he opted not to cooperate with the committee as an unconcerned banker was heading it and because he smelled foul-play.

The Rabbani government wasn't happy with Roshan over his handling of the bus-hijacking incident which culminated in the Afghan embassy in Islamabad. Demonstrations held in Kabul, apparently stage-managed by the Rabbani government, not only condemned the Pakistan Army commandoes assault on the Afghan embassy to secure release of schoolchildren hijacked by the three Afghans but also criticised Roshan and called for accountability. He was accused of failure to safeguard Afghanistan's honour and interests.

Certain reliable sources said deputy Afghan foreign minister $\mathrm{Dr}$ Najibullah Lafray had sent a radio message during the bus-hijacking crisis directing the Afghan embassy to extend help to the hijackers. He in particular wanted Engineer Mukhtar, charge d' affairs at the embassy and a nominee of the Rabbani government, to be of help to the three hijackers.

Sardar Roshan's supporters argued that the probe was a ploy to find an excuse to replace him. Another major point of contention between Roshan and the Rabbani government appeared to be the Rs 250 million amount lying in a branch of National Bank of Pakistan in Peshawar. It was the remaining amount out of the Rs 300 million donated by the then prime minister Nawaz Sharif on April 28, 1992 during a visit to Kabul after installation of a mujahideen government. About Rs 50 million were earlier withdrawn from the account to pay for salaries of Afghan teachers employed by the education department and payments owed by the Ariana Afghan Airlines.

While the Rabbani government reportedly wanted to withdraw this amount from the bank and make use of it, Roshan froze the account and deposited the amount in a fixed deposit scheme. The idea was to save the money until a representative government took over in Kabul.

It was understood that Sardar Roshan hasn't relinquished charge as ambassador against Kabul's wishes. Those backing him are convinced that he cannot be replaced until June 28 when Rabbani's term as president ends and the coalition government in Kabul falls apart. If the Rabbani government insists on replacing him, Pir Gillani's NIFA and other groups could turn decisively against the government.

Over the past two years, the mujahideen groups have consistently struggled to accommodate their own men in the Afghan embassies and consulates abroad. NIFA because the foreign ministry portfolio was allocated to it and Rabbani's Jamiat-i-Islami were able to induct the biggest number of diplomats in the foreign service.

Some anti-Rabbani elements accused the Rabbani government of the bus-hijacking incident and termed it as a conspiracy to pit Pakistanis against the Afghan refugees, most of whom are Pashto-speaking, in NWFP and Balochistan. The fact that not a single Pakistani school child was harmed in the Army com. mandoes assault foiled all such plans as Pakistanis refused to be provoked by the hijacking of the Peshawar school bus.

THE NEWS INTERNATIONAL 


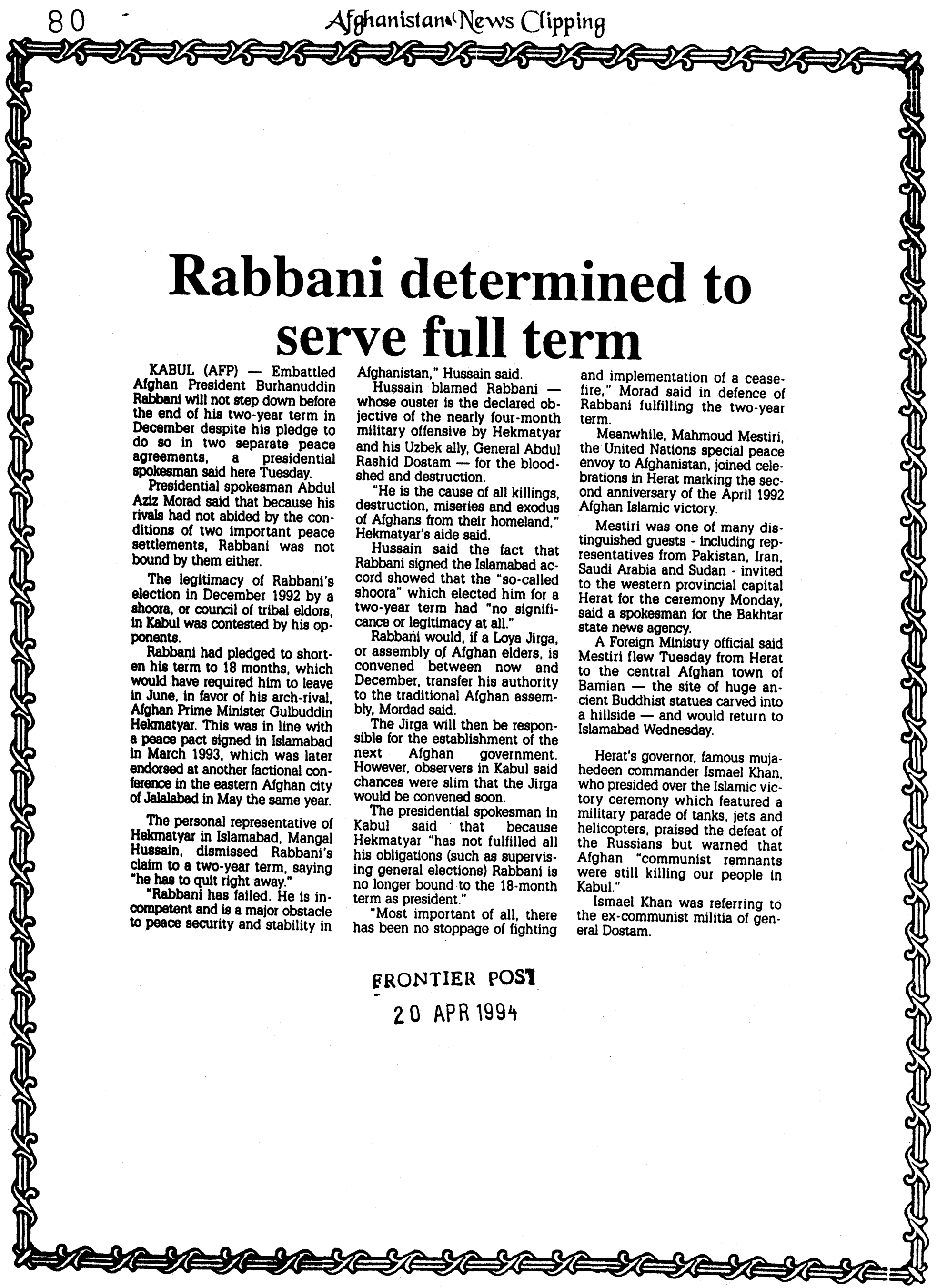




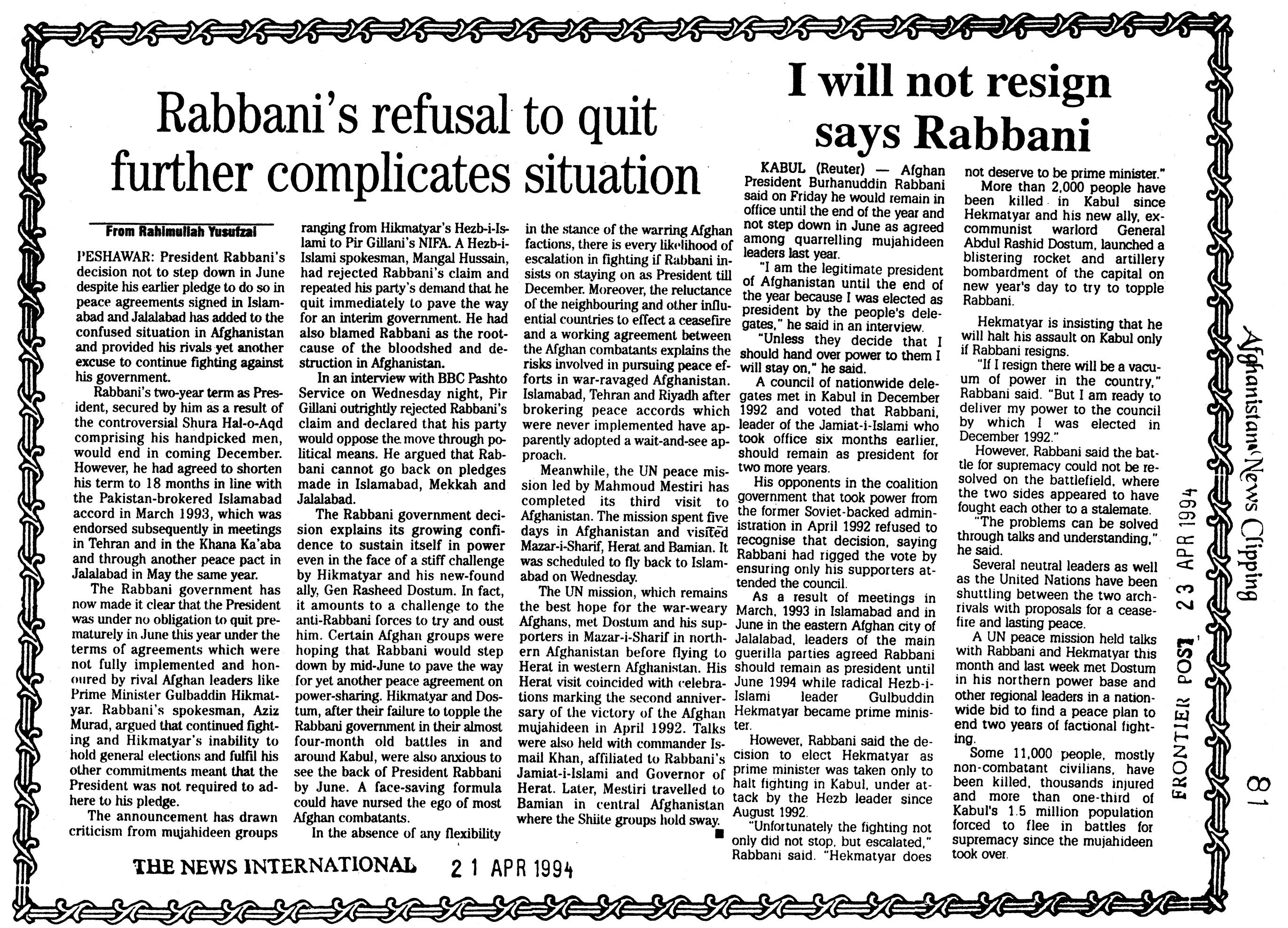




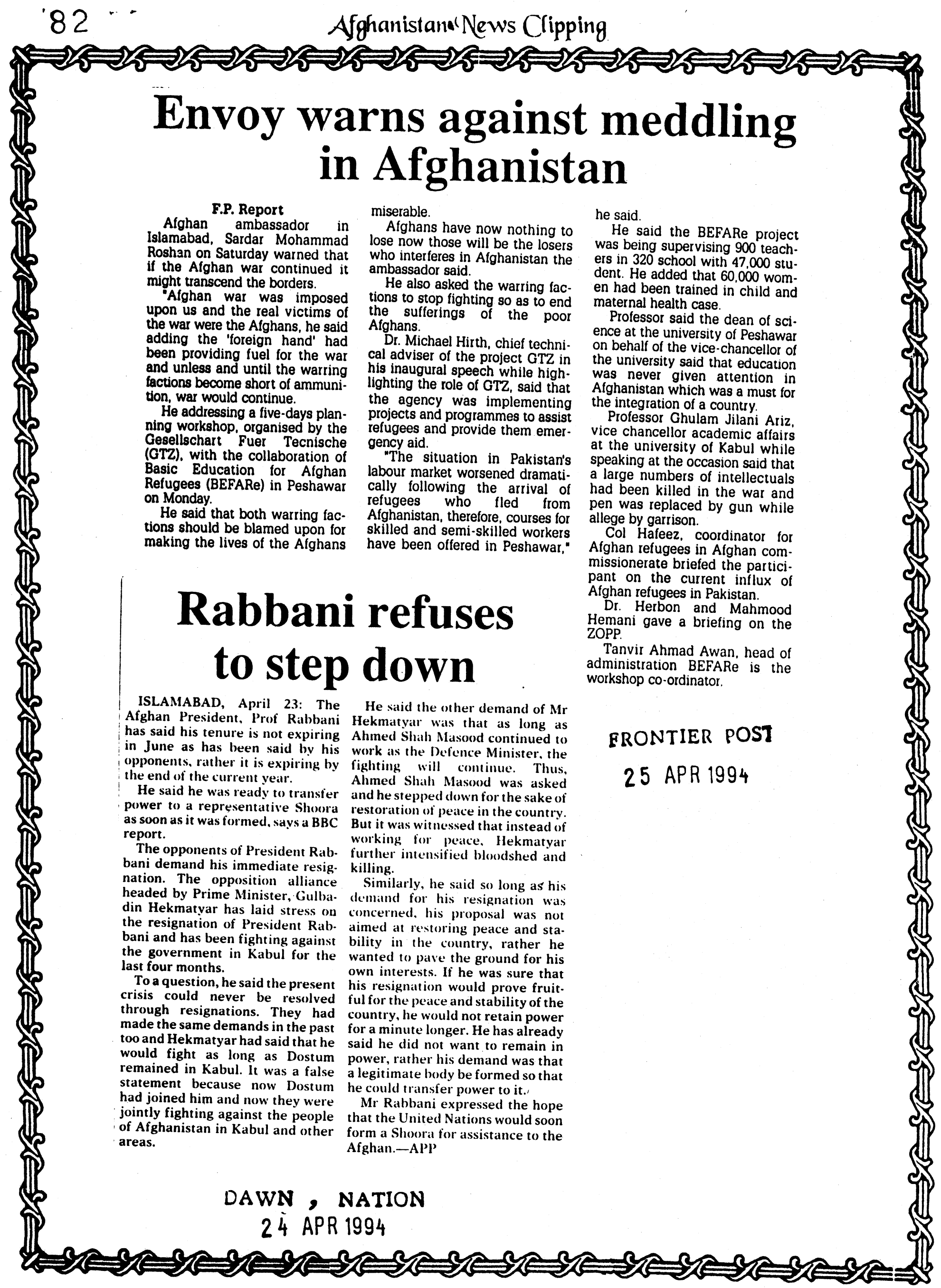




\section{Kabul museum's antiques seized}

\section{By IMTLAZ hUSSAIN}

ClA. Peshawar, in a big haul early on Thursday recovered antiques in three different raids at gold market. Koochi Bazar and Gulbahar. The relics were allegedly stolen from the Kabul museum some time back.

Two persons were arrested who according to police are the agents of a gang operating in US and other Western countries. As per detail, the CIA staff got the information that a gang operating in Peshawar. US and other countries had smuggled antiques which has allegedly been stolen from Kabul museum some time back. The smugglers had also concealed heroin powder in the antiques.

In this connection a CIA team was formed headed by Shah Wali Khan, DSP. CIA. The team raided the dens at gold market in Koochi Bazar and Gulbahar area.

According to CIA officials, the three raids were planned because the accused had hidden the antiques at different places in the city. According to them they used to shift their hideout after every three four days to avoid any suspicion.

During the raid, the officials recovered two maunds of 'topaz' worth lakhs of rupees, 34 statues worth millions of rupees in the international market, 16 swords of Mughal era, 23 other swords, five epitops and other antiques.

Experts in the local market while talking to The Frontier Post said that the seized antiques are worth millions of dollars in the in. ternational market. While in the local market price is estimated at millions of rupees. They said that for the past six months, there were reports that costly antiques stolen from Kabul museum were in the local market.

William Reeve, BBC correspondent in Kabul in his recent interview at BBC television said that the relics stolen from the Kabul museum had been sold in Peshawar. He also surveyed gold market in Peshawar and found the agents who deal in the business.
CIA, DSP, said that Ubedullah and Ibadullah, the gang leaders were in US since long. One of them has already been arrested by the US police while carrying 29 $\mathrm{kg}$ heroin powder. His other brother used to look after the gang activities in Western countries. Their two sons Qutbullah and Zabeehullah filled the antiques with heroin and allegedly dispatched them from Peshawar to US. Both were arrested by the CIA police.

The officials informed that the gang had allegedly contact with customs staff at Peshawar airport with the help of which they used to send the antiques abroad.

The officials said that in fact, the customs staff was also not aware of the smuggling of the heroin in antiques. They were only hired for the smuggling of antiques and not for the heroin powder concealed inside the antiques. The officials also recovered photographs of the antiques which were to be sent to the desired persons for striking a deal

ERONTIER POST

\section{Kabul demo demands opening of educational institutions}

\begin{abstract}
Bureau Roport
PESHAWAR: The people of the war battered Afghan capital on Tuesday held a demonstration in front of the United Nations office in Kabul to demand reopening of all the education institutions in the country.

A memorandum was also presented to the $U N$ representative asking the world body to help broker a permanent cease-fire in Kabul and also demanded resignation of the Afghan president and the prime minister to pave the way for the
\end{abstract}

convening of "Loya Jirga." The demonstrators also denounced the Kabul seminar which they said was organised by Shura-i-Nazaar of Ahmad Shah Masood and the enlightened people of the city did not take participate.

They supported the seminar to be arranged by the Nangarhar governor Haji Abdul Qadeer saying that the progressive and enlightened people of the country would take part in the Jalalabad seminar to be held for the restoration of peace in the country. 
A 100-kilograme (220 pound) bag of wheat flour -. for cooking the Afghan staple bread -- sold for 20.000 afghanis (10 dollars) cheaper in the south Kabul bazaars controlled by the mujahedeen of Prime Minister Gulbuddin Hekmatyar than in the city centre.

Due to his rivalry with President Burhanuddin Rabbani whose military forces control central Kabul. Hekmatyar has im posed a blockade on the free transport of food supplies into the capital, but he has allowed civilians to cross the front lines to purchase their needs at cheaper prices from his own bazaars.

But the people complained they had to pay bribes at many of

\section{Kabulites cross frontlines to buy cheap food}

KABUL (AFP) - Thousands of Kabul civilians took advantage of a lull in the four-month long Afghan factional fighting on Sunday to cross the front lines to buy cheap food and fuel available on the city outskirts. 100 kilograme bag of wheat flour sold for 20,000 Afghani Cheaper in the South Kabul bazaars controlled by the Mujadeen of PM Hekmatyar than in the city centre. Due to his rivalry with President Burhanuddin Rabbani whose military forces control Central Kabul, Hekmatyar has imposed a blockade on the free transport of food suplies into the Capital but he has allowed civilians to cross the front lines to purchase their needs at cheaper prices from his own bazaars. But the people complained they had to pay bribe at Hezb-i-Islami faction checkpoints along the way between the the South Kabul bazaars in Chelsitoon district and the first pro-Rabbani frontline checkpoint. "If I had known that I must pay so much money I would never have come," said one man.
Hekmatyar's Hezb-i-Islami faction checkpoints along the way between the south Kabul bazaars in Chelsitoon district and the first pro-Rabbani frontline checkpoint.

"if I had known that I must pay so much money I would never have come," said one man with a bag of wheat flour slung over his bicycle frame.

"They took my identity card just because I had no money to pay a bribe. They ordered me back tomorrow with the inoney if I wanted my card back," said another resident who had bought cooking oil.

Guards at the last Hezb-iIslami checkpoints on the way from Chelsitoon told AFP that allegations of bribe-taking were "lies", and insisted instead that they had opened the road for the free traffic of food "in order to help the people solve their problems."

A continuous stream of pedestrians, bicyclists and cart-pushers ferrying bags of wheat flour, loads of firewood and tins of petrol choked the southbound Chelsitoon road all morning as the supply caravan snaked its way to the capital centre.

Many sold their hard-won supplies to merchants who have set up a special bazaars in the city centre, but most said their food was for personal consumption. Several hundred thousand families who have been displaced by the factional fighting are going hungry in Kabul.

Meanwhile, a second route for the passage of cheap foodstuffs through the southwest Kabul ter- 4 ritory of Hekmatyar's Shiite Hezb$\mathrm{i}$-Wahdat allies was closed to civilians from areas controlled by pro-Rabbani troops.

Although no official announcement has been made of a Kabul ceasefire, the capital's front lines were quiet Sunday and no i.jokets were reported fired into the capital.

\section{Kabulis cross front lines to buy food}

KABUL, April 17: Thousands of Kabul civilians took advantage of a lull in the four-month-long Afghan factional fighting on Sunday to cross the front lines to buy cheap food and fuel available on the city outskirts.

A 100-kilograme bag of wheat flour - for cooking the Afghan staple bread - sold for 20,000 afghanis (10 dollars), cheaper in the south Kabul bazaars controlled by the Mujahedeen of Prime Minister Gulbuddin Hekmatyar than in the city centre.

Due to his rivalry with President

Burhanuddin Rabbani, whost military forces control central Kabul, Hekmatyar has imposed a blockade on the free transport of food supplies into the capital, but he has allowed civilians to cross the front lines to purchase their needs at cheaper prices from his own bazaars.
But the people complained they had to pay bribes at many of Hek matyar's Hezb-i-Islami faction checkpoints along the way between the south Kabul bazaars in Chelsi. toon district and the first pro-Rabbani fromtline checkpoint.

"If I had known that I must pay so much money I would never have come," said one man with a bag of wheat flour slung over his bicycle irame.

- They took my identity card just because I had no money to pay a bribe. They ordered me back tomorrow with the money if I wanted my card back," said another resident who had bought cooking oil.

Guards at the last Hezb-i.Islami checkpoints on the way from Chel sitoon told AFP that allegattions of bribe-taking were "lies", and See Next Page 
From Our Correspondent

PESHAWAR - Dr. Mohammad Amin Fatemi, Afghan Health Minister has succeeded in his efforts for accommodating the fifth year students of Kabul Medical Faculty in the Medical College of Jalalabad. He asked all the fifth year students of Medical Faculty of Kabul to participate in their studies to be started at Jalalabad Medical College on May 4 next.

According to a Press release issued here on Wednesday, Dr Amin Fatemi announced these achievements while addressing a news conference at Jalalabad. He informed that in this connection, a delegation of the Health Ministry headed by him held a detailed meeting with Governor of Nangarhar Haji Abdul Qadir. The delegation comprised Deputy Health Minister Dr. F. Kakar, Prof. Jalal, Prof. Ghazanfar and others.

Dr Amin Fatemi said that to enable 500 students of fifth year class of Kabul Medical Faculty of resuming their studies in Jalalabad, the World Health Organisation will provide funds. Likewise, boarding facilities to these students will be ensured by the Nangarhar Shura headed by Haji Abdul Qadir. He in this connection extended thanks to the World Health Organisation and Governor of Jalalabad.

The Afghan Health Minister who is also affiliated to Prof. Sibghatullah Mujaddadi's Afghan National Liberation Front said that Afghanistan was in dire need of maximum doctors. He said that as a result of fighting in Kabul, these 500 students have to suspend their studies and he wants early completion of their studies. He said that after getting support of the World Health Organisation and Nangarhar Shura, these students will early conclude their education and after it they will be sent to various health institutions of war devastated Afghanistan for serving the ailing and helpless people of that country.

Answering to a question, Dr Amin Fatemi said that apart from these 500 students a large number of their colleagues from fourth and third year have also suspended their education. He said that Afghan Ministry is struggling to mobilise resources to enable these students of resuming their education in Jalalabad. In this connection, the Afghan Health Ministry was in contact with various countries and donor agencies.

Dr Amin Fatemi said these are temporary arrangements as due to fighting in Kabul, it is very difficult for these students to continue their studies. He said that whenever situation became normal, all these students would resume their education in Kabul. He said that around 2000 medical students of Kabul Medical Faculty have to suspend their education in Kabul.

Dr. Amin Fatemi suggested the medical students residing in Peshawar and other parts of Frontier Province to contact the Ministry of Health, Afghan Trauma Centre Nasar Bagh road, Peshawar through telephone number 44566.

\title{
Kabulis cross front lines...
}

\begin{abstract}
insisted instead that they had hundred thousand families who opened the road for the free traffic have been displaced by the fac. of food "in order to help the people tional fighting are going hungry in solve their problems." A continu. Kahul.

ous stream of pedestrians, bicyc. Meanwhile, a second route tor lists and cart-pushers ferrying bags the passage of cheap foodstuffs of wheat flour, loads of firewood through the southwest Kabul territ. and tins of petrol choked the south- ory of Hekmatyar's Shiite Hezb-ibound Chelsitoon road all morning Wahdat allies was closed to civias the supply caravan snaked its lians trom areas controlled by pro. way to the capital centre.

Rabbani troops.

Although no official announce. Many sold their hard-won ment has heen made of a Kabul supplies to merchants who have set ceasefire, the capital's front lines up a special bazaars in the city were quiet on Sunday and no roc. centre, but most said their food was kets were reported fired into the for personal consumption. Several capital. - AFP
\end{abstract}

\section{APR 1994}




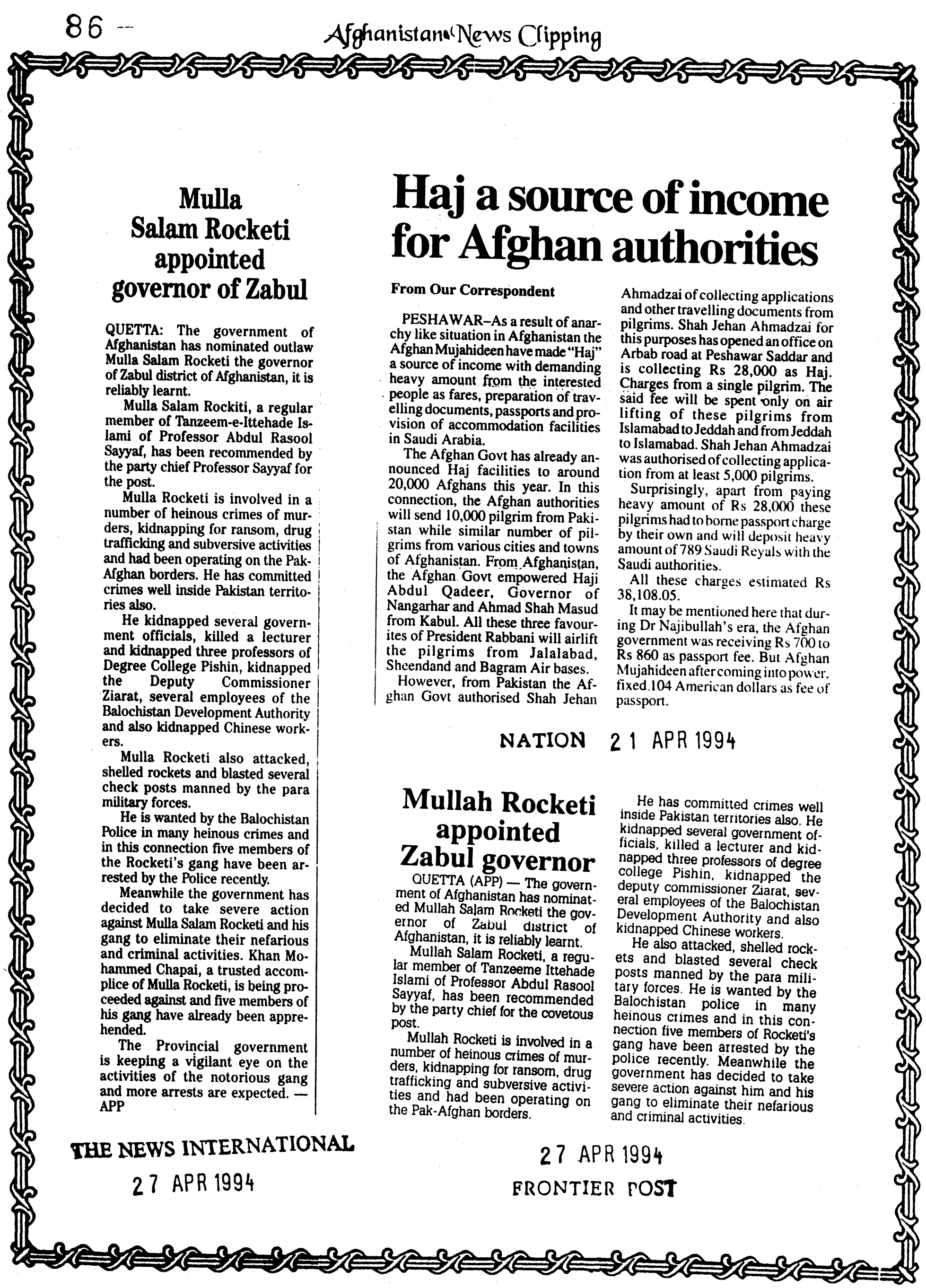




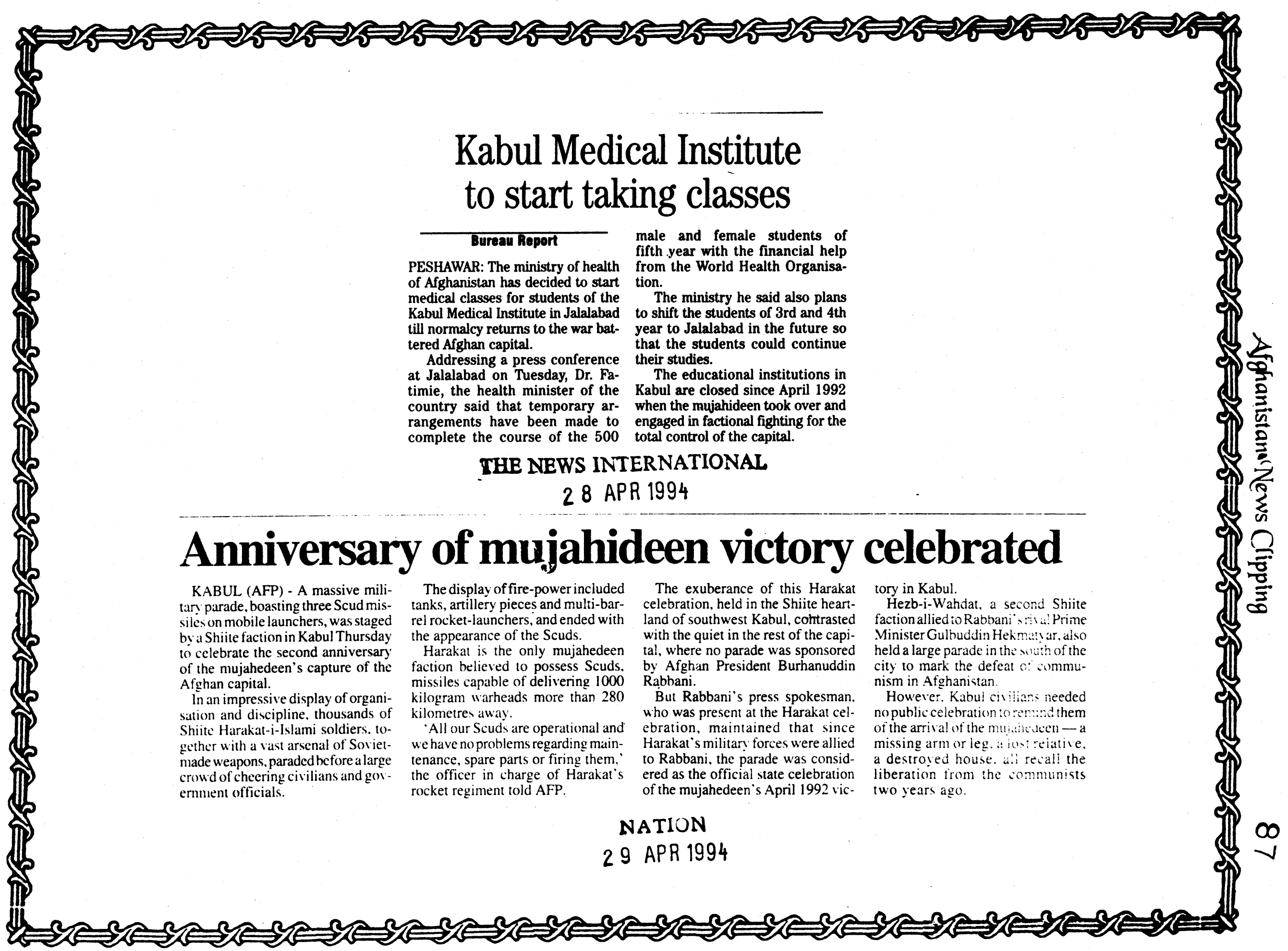




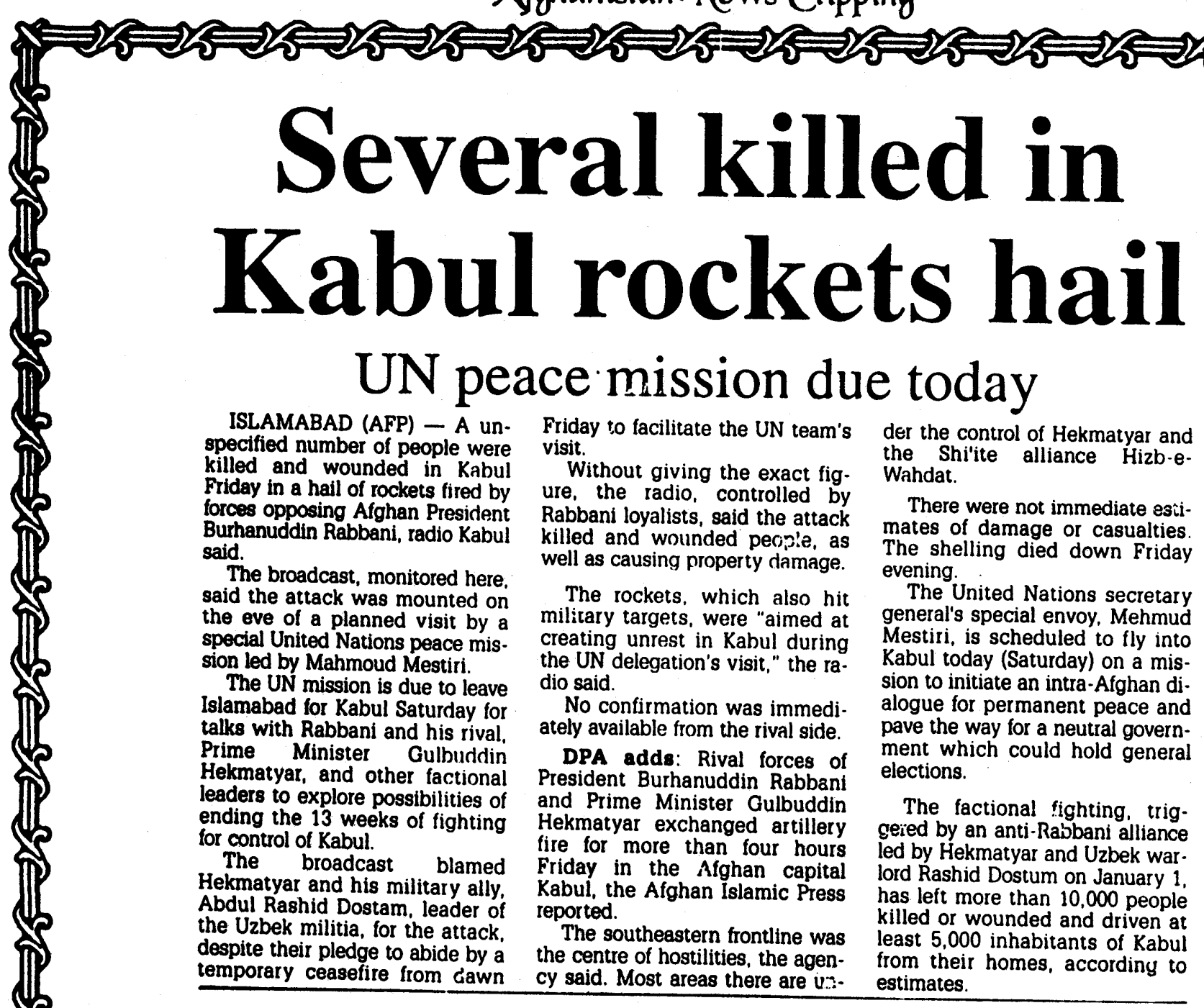
number of people were illed and wounded in Kabul inday in a hail of rockets fired by Raboani, radio Kabul pecial United Nations peace misThed Mahmoud Mestiri.

The UN mission is due to leave Slamabad for Kabul Saturday for eaders to explore possibilities of the 13 weeks of fighting despite their pledge to abide by a temporary ceasefire from clawn
Friday to facilitate the UN team's isit.

The rockets, which also hit military targets, were "aimed at o said. President Burhanuddin Rabban Prime Minister Gulbuddin ed artillery in than four hours abul, the Afghan Islamic Press

the centre of hostilities, the agency said. Most areas there are $\mathrm{v}$ :-

\section{Kabul shelled despite ceasefire: six killed}

KABUl,, March 31: Six civilians were killed and 38 others wounded during heavy fighting on the east ern trontlines early on Thursday by factions battling for and agains Atghan President Burhaunddin Rabbani in spite of the ceasefire accord.

The .44 casualties recorded at Kabul's four main hospitals were calught in the axchange of scores of rockets and heavy artillery shells in the fighting which lasted three hours.

The sporadic shelling brought civilian traftic on the main streets of ile eastern suburlos 10 a standstill.

A defence ministry offichal sitid combined units of Uzbek wallord General Ahdul Rashid Dostum and his Pushoun ally Prime Mlinister Gubudilin Hekmatvar antarked
pro-Rabball iorces delending the State Bus Station but were repulsed with heavy losses.

"Against our expectations and the expectations of the people that the other side would respect at ceasefire for the visit of the United Nations envoy they launched an attack against us," said the official

UN special envoy Mahmoud Mestiri is expected in the capital on Saturday, provided there is adequate security.

Mestiri's visit is expected (1) pave the wav for a solution to end the tactional lighting which has plagued habul since the Mujahe. dech entered the capital in April 1992

As the UN has traditionally been intimidated by Afghan conflicts clionsing to administer its Kabulbased programmes from neighbouring Pakistan -. many people bolieve Mestirits visit will be little more than a tlas-waving ilfiail $-\mathrm{Al}$ !"

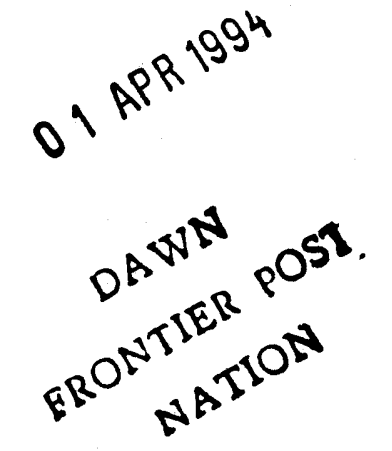




\section{Mestiri sick as fighting re-erupts in Kabul}

KABUL (AFP) - Ill-health Monday forced a United Nations peace mediator to cancel key meetings in Kabul aimed at ending Afghanistan's civil war, after rival factions overnight exchanged rocket fire and skirmishes erupted around the beleaguered capital.

UN special peace envoy, former Tunisian foreign minister Mahmud Mestiri, had been due to meet former Afghan Defence Minister Ahmad Shah Masood on Monday morning, but had to cancel the encounter after he was laid low with a stomach disorder. officials said.

UN Co-ordinator for Afghan Humanitarian Assistance, Sotiros Mousouris, took Mestiri's place in the two-hour discussion with Masood President Burhanuddin Rabbani's military right-hand-

On Sunday Mestiri met the president's sworn enemy, Prime Minister Gulbuddin Hekmatyar, but did not manage to narrow differences between the the two rivals significantly.

An aide to Masood described the talks with Mousouris as a "background discussion" to the conflict, which has left 10,000 people dead since the fall of the communist regime in April 1992 when mujahedeen forces took

control of the capital

Mestiri is heading a sevenmember peace delegation on the third day of a visit to the war-torn country to assess a possible UN role in establishing permanen peace in Afghanistan

A temporary ceasefire promised in force since the dele gation arrived Saturday has been almost fully respected by combatants, with the exception of a onehour exchange of rockets and mortars on the front line east of Kabul overnight Sunday.

Also in the Tagob Valley, about 60 kilometers (37 miles) northeast of Kabul, where Massoud and Hekmatyar's men battled against each other last November, new fighting broke out Sunday with each side accusing the other starting it.

Meanwhile, some $220 \mathrm{kms}$ (130 miles) north of the capital Masood's forces launched a Sunday offensive against the strategic centre of Pul-i-Khumri which is defended by the rival Uzbek faction of warlord General Abdul Rashid Dostam and their

A military source in Kabul said Masood's men had captured six security posts on Pul-i-Khumri's perimeter and killed 30 enemy soldiers in the attack, which inde pendent sources said was preced ed by a massive artillery bombardment.

Pul- $\mathrm{i}-\mathrm{Khumri}$ is the headquarters of the Ismaelia 80th Kayan Division headed by Sayyad Jaffa Naderi. of whom 1,000 men are reported to have surrendered with heir wo have surrendered with commanders.

The mainstay of Pul-i-Khumri's defence is Dostam's ex-communist Uzbek militia, which also holds the former Russian army base of Qelagai half an hour's drive south.

Masood jets have reportedly been bombing Oelagai whil Dostam aircraft have retaliated against the former Ismaelia-controlled town of Doshi furthe south, captured by Masood about three weeks ago.

The defence of Pul-i-Khumri is vital for Dostam, as its fall would allow Masood an open road to march on the Uzbeks' own strongholds of Mazar-isharif and

The UN delegation obtained a promise of a "permanent and unconditional" ceasefire from ceasefire from Rabbani. but Hekmatyar has vowed there can be no lasting peace unless

Mestiri and his group are due to return to Pakistan Tuesday.

\section{Rival forces exchange artillery fire in Kabul}

PESHAWAR: Rival forces of President Burhanuddin Rabbani and rebel Prime Minister Gulbudin Hekmetyar exchanged artillery fire for more than four hours Friday in Kabul, the Afghan Islamic Press re ported.

The south-eastern front line was the centre of hostilities, the agency said. Most areas there are under the control of Hekmetyar and the shi'ite alliance Hizbe Wahadat. There were not immediate estimates of or casualties. The shelling died down Friday evening.

United Nations Secretary General's Special Envoy, Mehmud Mestiri, is scheduled to fly into Kabul Saturday on a mission to initiate an intra-Afghan dialogue for permanent peace and pave the way for a neutral government which could hold general elections.

The factional fighting, triggered by an anti-Rabbani alliance led by Hekmetyar and Uabek Rashid Dostum on January 1, has left more than 10,000 people killed or wounded and driven hundreds of inhabitants of Kabul from their homes. - DPA

THE NEWS INTERNATIONAL 02 APR 1994 
KABUL (AFP) - Defence ministry troops loyal to Afghan President Burhanuddin Rabbani repulsed a night-time attack by rival forces early Sunday morning, a military source reported.

Some 30 rockets were fired on the capital during the attack, the source said.

The attack was launched against a lower level of the Rabbani-controlled Sherdarwaza mountain by a joint force of rival faction leaders Prime Minister Gulbuddin Hekmatyar and General Abdul Rashid Dostam.

"In revenge for their defeat they rocketed the city," a defence ministry official said of the attack, launched from the ancient fortress of Bala Hissar on the eastern out- skirts of the capital.

Eight persons with shrapnel wounds were admitted to the downtown Jamhuriat hospital, 10cal staff reported.

Residents in the eastern Wazir Akbar Khan district were awoken around 2:30 a.m (2200 GMT) at the start of the fighting, but by suntise calm was restored in the capital and the front lines were quiet.

Sunday was the last day of a two-week unilateral ceasefire announced by Rabbani in honour of the Afghan New Year celebrations, and there was no official notice of an extension.

In spite of a flurry of peace seminars and peace delegations here there has been no mutual agreement about how to end the current bout of factional fighting. now in its 14th week.

Meanwhile, fighting between pro-Rabbani forces and the Hekmatyar-Dostam alliance was continuing in the Tagob Valley some 60 kilometres (37 miles) northeast of Kabul, and around the centre of Pul-i-Khumri some 200 kilometres (125 miles) north of the capital.

In south Kabul, gunmen of Hekmatyar's Shiite ally, the Hezb$i$-Wahdat faction, stopped the free passage of wheat flour into Rabbani-controlled northern parts of the capital, which they had allowed Saturday.

"We noticed that the same people were going back and forward. They weren't taking the flour for their own use but to sell for a profit," explained an angry Wahdat checkpost commander.

\section{6 killed in rocket and jet blitz on Kabul}

KABUL: At least 16 civilians were killed and 144 were wounded in Kabul Monday in a jet strike and a heavy artillery bombardment by rival faction forces battling Afghan President Burhanuddin Rabbani.

The 16 deaths resulted from a single bomb dropped by a jet of Uzbek warlord General Abdul Rashid Dostam, which apparently missed its military target - heavy weapons based on adjacent Bibi Mahru Hill and demolished a crowded pharmacy instead.

Witnesses said the jets dropped six bombs in two sorties over the capital.

Another bomb landed on a Rabbani-controlled hill behind the residential neighborhood of Waxir Akbar Khan in east Kabul. Most civilians have fled Warir Akbar Khan, but it is still home to the International Committee for the Red Cross.

There were no reports of any fatalities from an earlier jet strike against the strategic television tower in central Kabul, on which pro-Rabbani troops man many heavy weapons sites.

The local security commander near Bibi Mahuru said his men car- ried away 14 severely wounded from the pulverised pharmacy, none of whom he expected to live.

The bodies of four brothers who owned the east Kabul pharmacy which took direct hit though the roof were completely vaporised while many others - mostly young children - were dismembered beyond recognition.

Stunned locals who survived the attack dug into the blood-stained wreckage in search of relatives still buried inside.

"Find my brother and dig him out from here," sobbed a young boy to helpless security guards, as passing vehicles were commandeered to carry the wounded.

The jet strike followed four hours of shelling by the joint forces of Dostam and his Pushtun ally, Prime Minister Hekmatyar, which continued intermittently till late afternoon.

The Japanese embassy was also hit in the renewed fighting in the eastern and southeastern parts of the war-devastated capital, the Afghan Islamic Press reported.

The fresh outbreak of violence in the nearly four-month-old bout of Kabul factional fighting came just five days after the departure of the United Nations special peace mission to the capital headed by Mahmud Mestiri.

In northern Afghanistan, Rabbani's troops were fighting outside Pul-i-Khumri, in Baghlan province, a stronghold of Dostum's ally, Sayed Jaffer Nauderi.-Agencies 


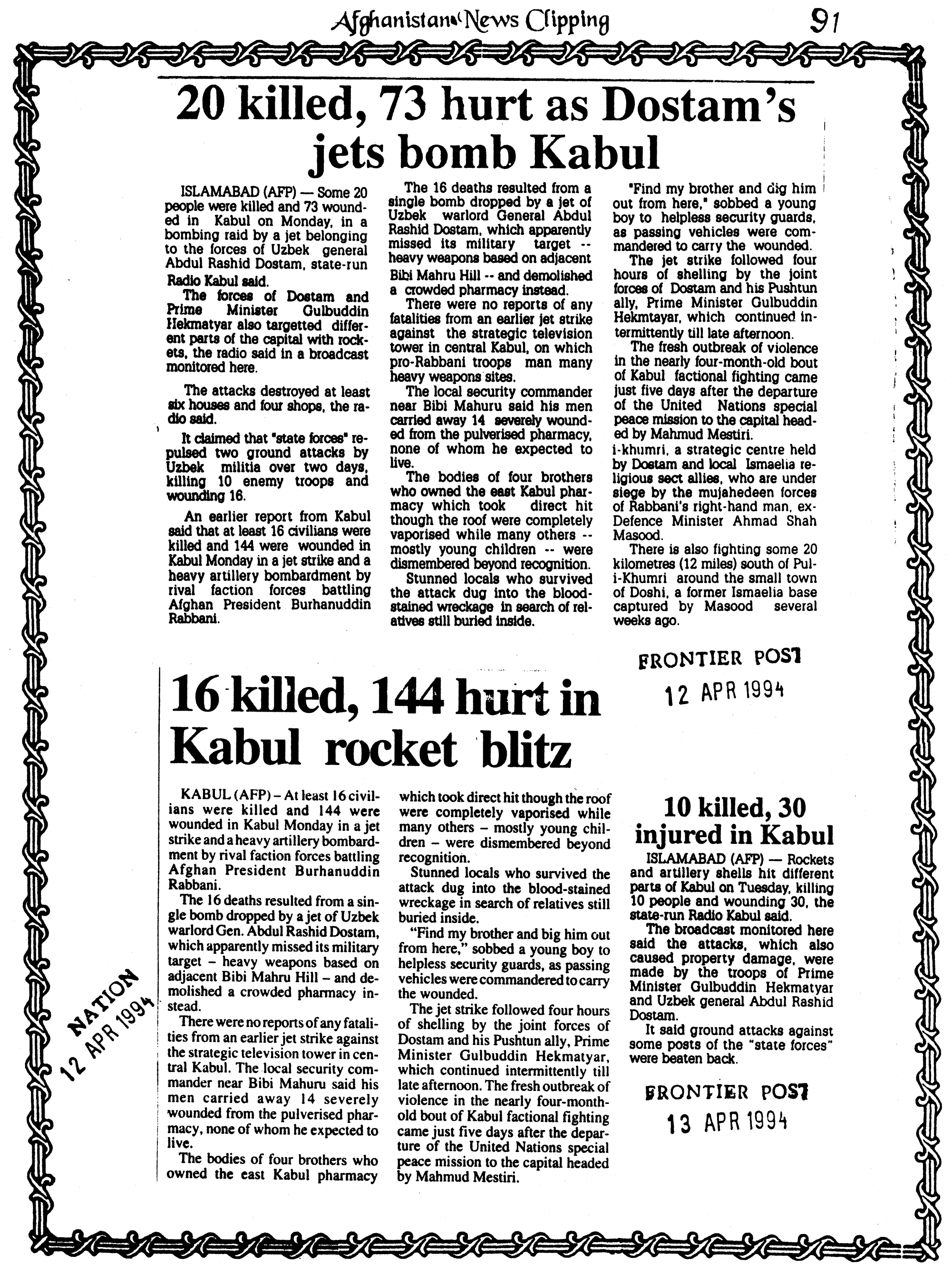




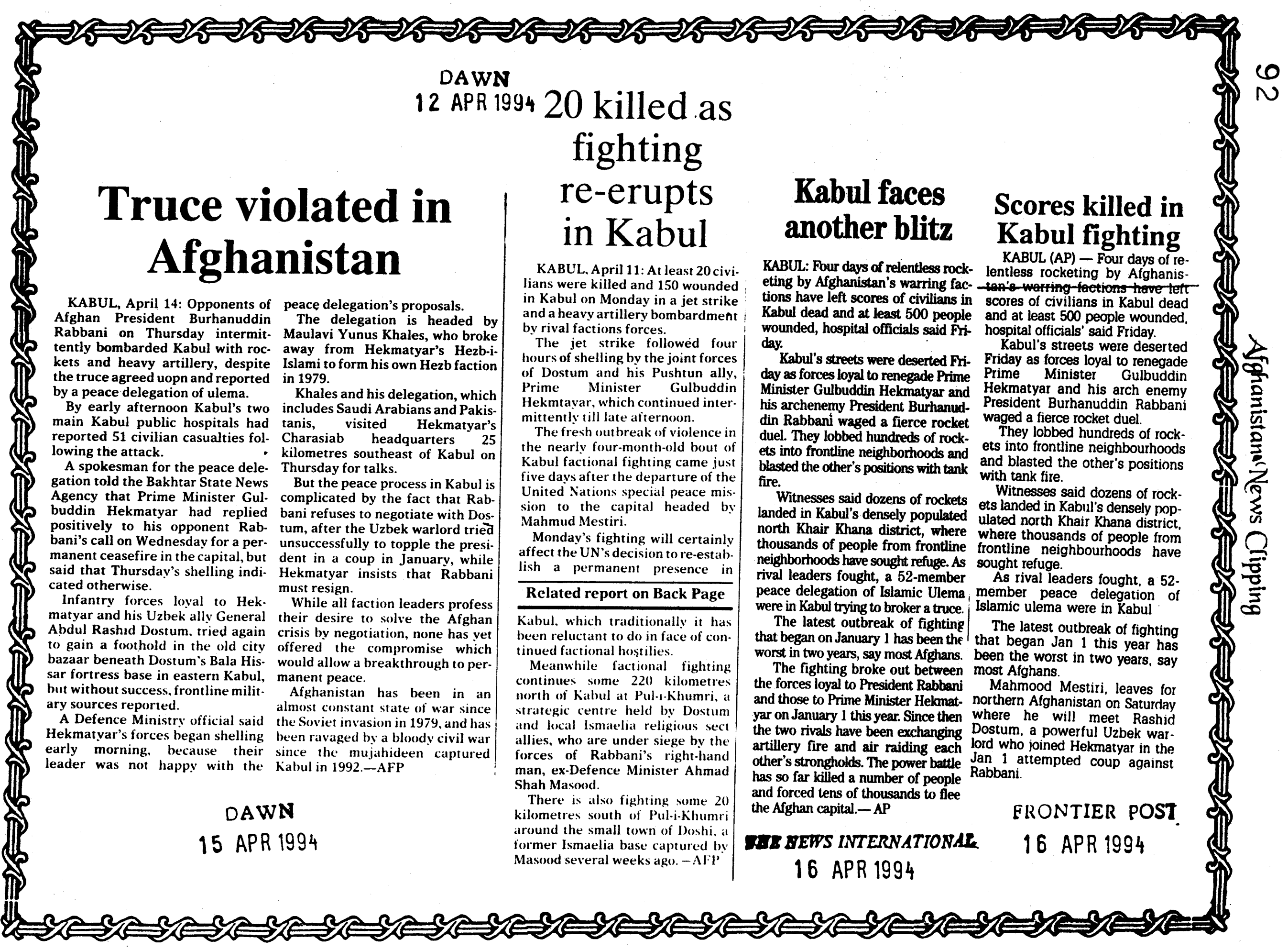




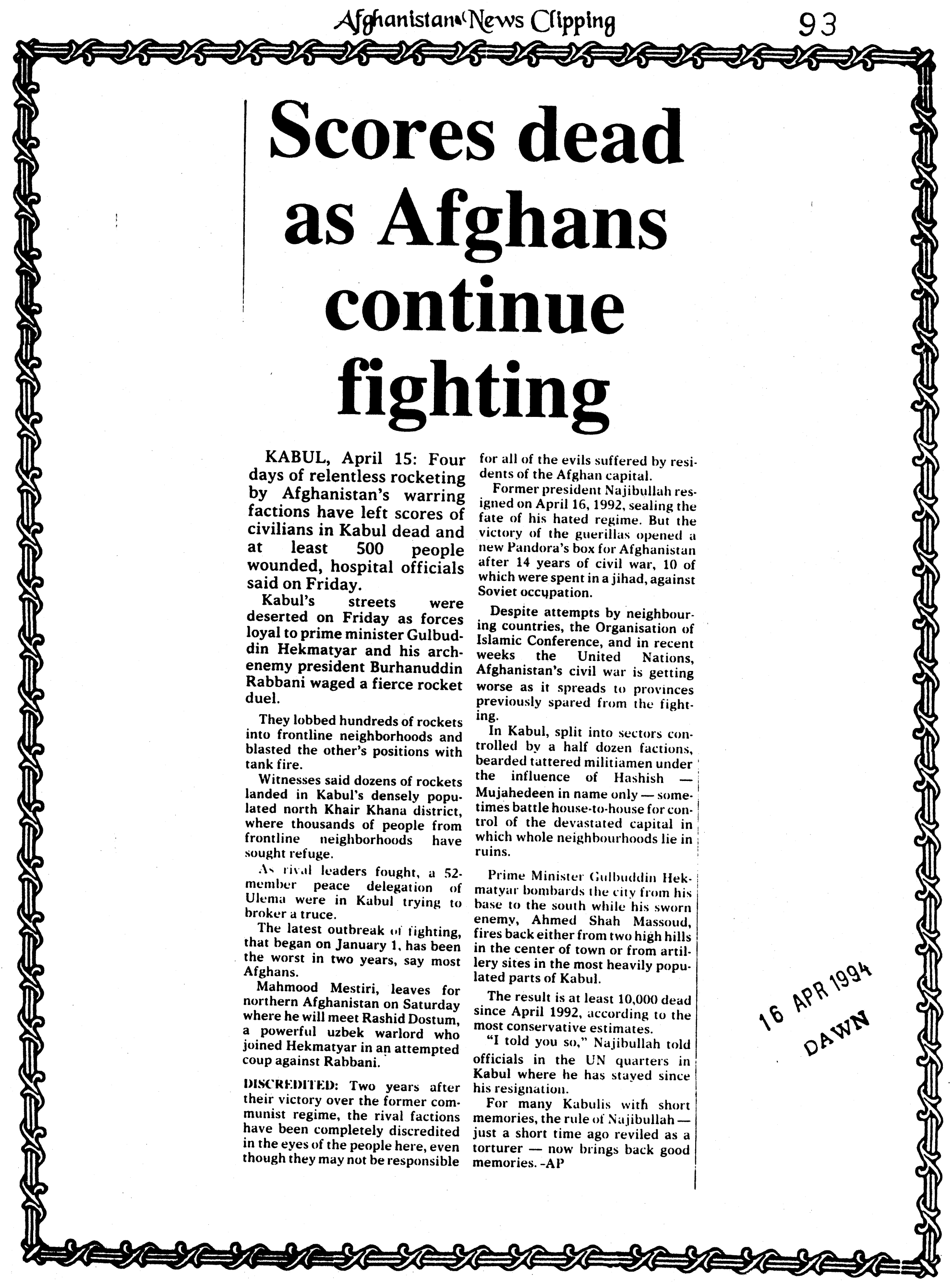




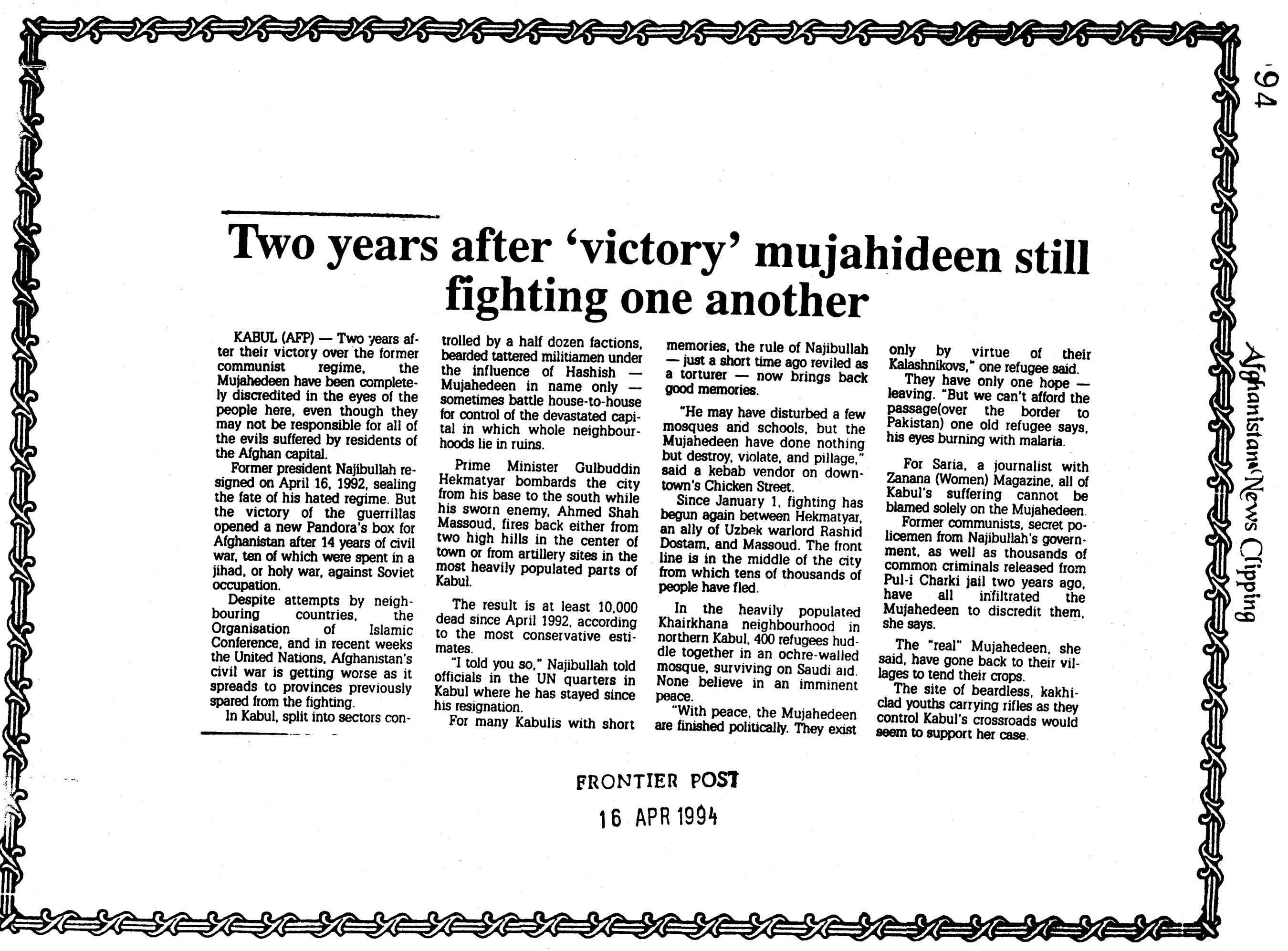


KABUL (AFP) - The Kabul headquarters of the Red Cross took three direct hits by heavy artillery Saturday, as factions fighting for and against President Burhanuddin Rabbani failed to reech a peace agreement.

The Islamic clerics' peace delegatton now in the capital failed to get the agreement of Rabbani's rival, Prime Minister Gulbuddin Hekmatyar, for a permanent Kabul ceasefire, said presidential spokesman Abdul Aziz Morad.

"Hekmatyar will only accept a ceasefire when his ammunition is finished," he added.

The International Committee of the Red Cross building in eastern Kabul was quickly evacuated of staff after the three $120 \mathrm{~mm}$ mor tars hit before noon, the local security officer sajd.

"Fortunately, no one was hurt because we had taken the precau tion of sandbagging all the walls. windows and doorways," the official said.

Even though the sandbags had abeorbed all the incoming shrapnel, wooden doors and windows behind the protective barrier were torn apart by the fierce shockwaves of the explosions.

The mortar salvo was the exception to an otherwise peaceful day in Kabul that pro-Rabbani front-line troops used to rest and to clean their weapons.

General Ahmadi, commander of the Islamic Army of Afghanistan's 1st Infantry Division, said Friday and Saturday were relatively quiet days after four days of heavy fighting against Hekmatyar's Hezb-iIslami faction and their Uzbek al. lies, the ex-communist militia of General Abdul Rashid Dostam.

Ahmadi said these rival forces had launched their infantry offengive through the back streets of the old city bazaar after a concentrated artillery bombardment, in an attempt to link their Bala Hissar base with their forces in south Kabul.

"They gave their maximum offort but made no territorial gains," Ahmadi declared, indicating heavy casualties on both sides.

Ahmadi alleged that if the offensive had been successful in breaking through to the south. the plan was for Hekmatyar's Shite Hezb-i-Wahdat allies who have remained neutral in this latest bout of Kabul fighting - to join the fray and launch their own attack against pro-Rabbani troops.

The commander added that the recent Hezb-Uzbek offensive had a secondary aim, to try to force the withdrawal of proRabbani troops from the battle. field some 200 kilometres (125 miles) north of Kabul to reinforce the capital, but added this tactic had also failed.

Rabbani's military strongman. ex-defence minister Ahmad Shah Masood, is directing an offensive against the strategic northern centre of Pul-i.Khumri, defended hy Dostam and his religious sect allies.

Meanwhile, an Afghan volunteer agency took advantage of the relative calm in Kabul to distribute 15 tonnes of UN-donated wheat flour in the northwest of the capital to some 300 families displaced by the factional fighting. now entering a 16th consecuttive wook.

\section{Shells hit Red Cross HQ in Kabul: truce bid fails}

KABUL (AFP) - The Kabul headquarters of the Red Cross took three direct hits by heavy artillery Saturday, as factions fighting for and against President Burhanuddin Rabbani failed to reach a peace agreement.

The Islamic clerics' peace delegation now in the capital failed to get the agreement of Rajbani's rival, Prime Minister Gulbuddin Hekmatyar, for a permanent Kabul ceasefire, said presidential spokesman Abdul Aziz Morad.

Hekmatyar will only accept a ceasefire when his ammunition is finishod,' he added.

The International Committee of the Red Cross building in eastern Kabul was quickly evacuated of staff after the three $120 \mathrm{~mm}$ mortars hit before noon, the local security officer said.

'Fortunately, no one was hurt because we had taken the precaution of sandbagging all the walls, windows and doorways,' the official said.

Even though the sandbags had absorbed all the incoming shrapnel, wooden doors and windows behind the protective barrier were torn apart by the fierce shock-waves of the explocions.

The mortar salvo was the exception to an otherwise peaceful day in Kabul that pro-Rabbani front-line troops used to rest and to clean their weapons.

General Ahmadi, commander of the Islamic Army of Afghanistan's 1 st Infantry Division, said Friday and Saturday were relatively quiet days after four days of heavy fighting against Hekınatyar's Hezb-i-Islami faction and their Uzbek allies, the ex-communist militia of General Abdul Rashid Dostam.

Ahmadi said these rival forces had launched their infantry offensive through the back streets of the old city bazaar after a concentrated artillery bombardment, in an attempt to link their Bala Hissar base with their forces in south Kabul.

'They gave their maximum effort but made no territorial gains,' Ahmadi declared, indicating heavy casualties on both sides.

Ahmadi alleged that if the offensive had been successful in breaking through to the south, the plan was for Hekmatyar's Shiite Hezb-i-Wahdat allies - who have remained neutral in this latest bout of Kabul fighting - to join the fray and launch their own attack against pro-Rabbani troops.

The commander added that the recent Hezb-Uzbek offensive had a secondary aim, to try to force the withdrawal of pro-Rabbani troops from the battlefield some 200 kilometres north of Kabul to reinforce the capital, but added this tactic had also failed.

Rabbani's military strongman, exdefence minister Ahmad Shah Masood, is directing an offensive against the strategic northern centre of Pul-i-Khumri, defended by Dostam and his religious sect allies.

Meanwhile, an Afghan volunteer agency took advantage of the relative calm in Kabul to distribute 15 tonnes of UN-donated wheat flour in the northwest of the capital to some 300 families displaced by the factional fighting, now entering a 16th consecutive week.

\section{NATION}

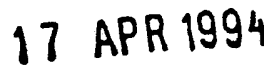




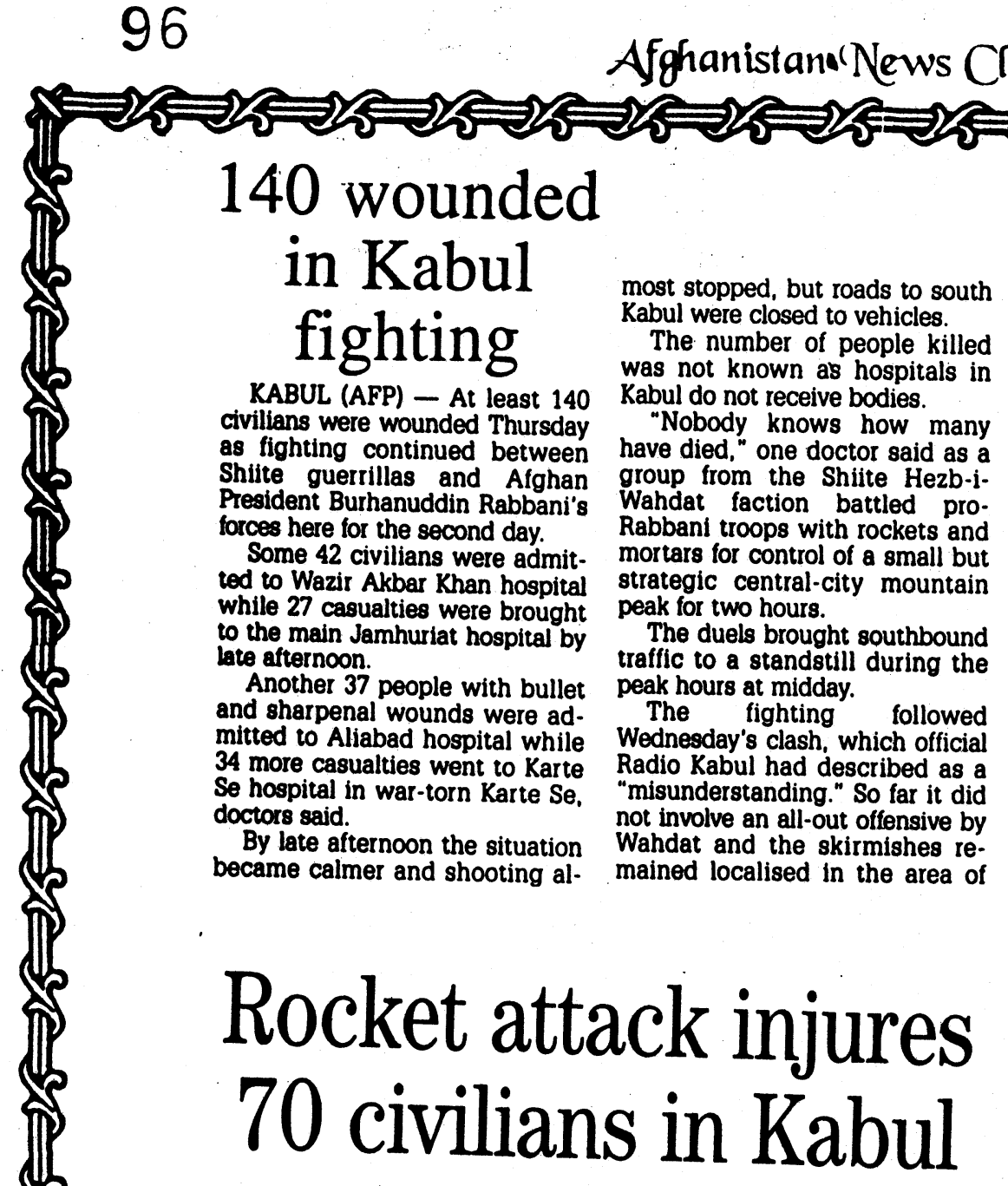

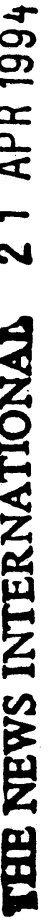
AFP

KABUL: More than 70 civilians have been admitted to Kabul hospitals following rocket attacks early Wednesday and ongoing skirmishes between presidential troops and rebel factions, hospital sources said.

At least 30 civilians were wounded and several others killed as rockets slammed into the Afghan capital early Wednesday, while troops loyal to President Burhanuddin Rabbani clashed with the Shi'ite Hezb-i-Wahdat faction near a strategic mountain top in the city's centre, the sources said.

Meanwhile, fighting on the eastern front lines between Rabbani loyalists and the joint attacking force of Uzbek General Abdul Rashid Dostam and Prime Minister Gulbaddin Hekmatyar resulted in 44 civilians being wounded in crossfires, they said. The wounded were admitted to the northern Waxir Akbar Khan hospital. It was not known how many had died in the clashes.

However, fighting between proRabbani troops and Wahdat on a minor peak below the strategic mountain top, on which stands a television tower, was considered a local affair and not a major attack by either side, military onlookers said.

South Kabul's Karte Se hospital renorted five civilians wounded in cluding a pregnant woman, after a rocket slammed into their house, killing two other occupants, doctors said. Many of the main bazaars in southern and western Kabul became deserted as stray incoming rounds and the sight of explosions along the central Kabul mountain ridge warned travellers to stay on the backstreets.

Hekmatyar and Dostam, who have tried for 16 weeks to topple Rabbani by force, have yet to convince their nominal Wahdat ally to join the current round of factional fighting, although the extensive network of bunkers and trenches in southwest Kabul indicate a degree of military preparedness.

Some 200 kilometres north of the capital, fighting continued around the strategic centre of Pul-i-Khumri where Dostam and his Ismaelia religious sect allies are under siege by pro-Rabbani troops led by former defence minister Ahmad Shah Masood.

A defence ministry official denied claims by Hekmatyar that the former Ismaelia-controlled town of Doshi had been recaptured by Dostam forces. "Doshi is in our hands but there are some hills in the surrounding area from which the enemy can bombard us at will," the official said, frankly. He added a military convoy carrying relief supplies had been dispatched to Doshi, in a "clear sign the town is
Salam Hill just below the strategic television tower mountain.

Wahdat, a nominal ally of Prime Minister Gulbuddin Hekmatyar and Uzbek General Abdul Rashid Dostam, who have been battling to topple Rabbani for the past 16 weeks, has so far resisted encouragement to open a new front in the south with a ma. jor offensive.

However, the commander of frontline pro-Rabbani troops stationed in the Kabul Zoo said some units of Wahdat were trying to capture Salam Hill. If they capture it they would be able to cut the supply road which passes nearby and continues to the top of the television tower peak, the most important defence position for the pro-Rabbani forces.

The balance of power in Kabul could be radically changed in favour of the joint attacking forces if Wahdat captured the centralcity peaks, or at least cut the supply of ammunition to Rabbani's heavy weapons there.

In apparent support of the Salam Hill fighting, harassment fire from various Wahdat posts also pounded the residential area behind Dehmazang Square, where mortar shrapnel ripped out a chunk of one civilian's skull.

\section{0 injured in Kabul fighting}

KABUL, Apral 20 Nane han 70 civilians have been atmitted Io Kabul hospitals followme rocket attacks early Wednesdaty and ongoing skirmishes between presidential troops and rival factions, hospital soutces said.

At least 30 civilians were wounded and several others killed as rockets slammed into the Afghan capital early Wiednesday. while troops loyal to President Burhanuddin Rabbani clashed with the Shia Hezb-i-Wahdat fac tion near a strategic mountain top in the city's centre, the sources aid.

Meanwhile, fighting on the eastern front lines between Rabbani loyalists and the joint attacking force of Uzbek General Abdul Rashid Dostum and Prime Minister Gulbuddin Hekmatyar resulted in 44 civilians being wounded in crossfires, they said.

The wounded were admitted to the northern Wazir Akbar Khan hospital. - AFP
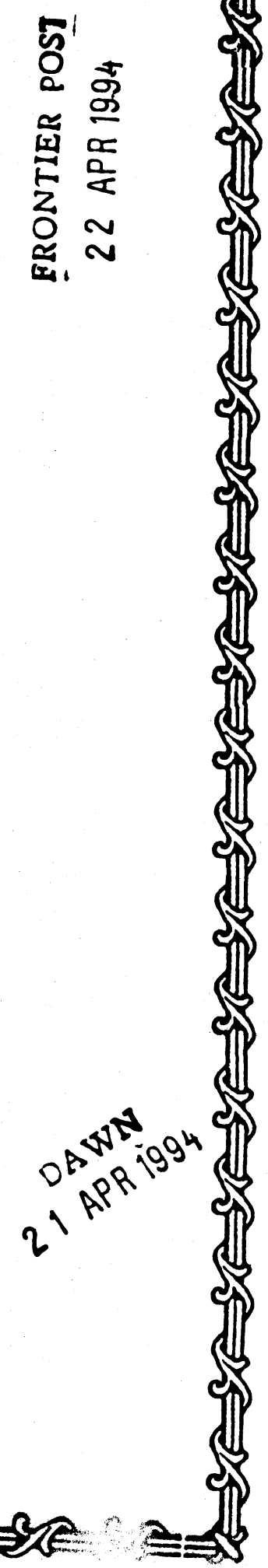


\section{8}

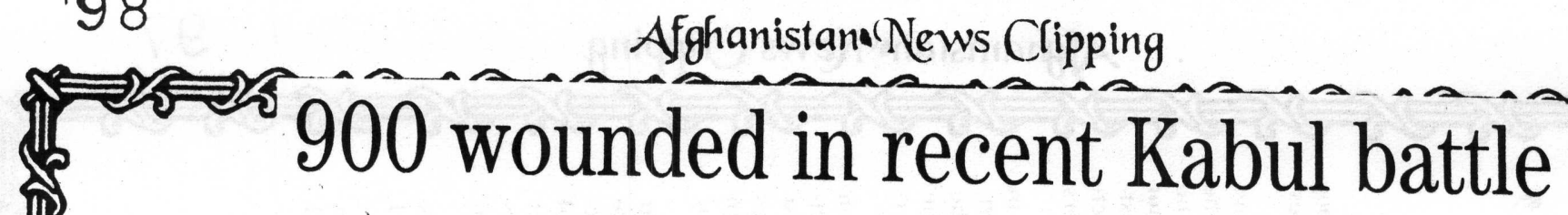

\section{AFP}

KABUL: More than 900 Afghan civilians and mujahideen have been wounded in fierce factional fighting north of Kabul in the past three weeks, hospital sources said Tuesday, but no estimates of the death toll could be obtained.

Kabul itself was relatively calm except for a few rocket and mortar fires heard in the Wazir Akbar Khan diplomatic enclave, where a military hospital was hit by two rockets. No casualties were reported.

The heaviest fighting has been around the strategic centre of Pul-i-Khumri, some 220 kilometres (140 miles) north of Kabul, where the forces of ex-defence minister Ahmed Shah Masood have laid siege to Uzbek warlord General Abdul Rashid Dostam, who failed in a January attempt to topple President Burhanuddin Rabbani.

Travellers from the area report a current lull in hostilities but in the preceding three-week period 838 military and civilian patients were treated at the Charikar hospital further south, doctors said.

There is an apparent stalemate in the north where Dostam and his Ismaeli religious sect allies hold Pul-iKhumri and the nearby former Russian army base of Qelagai. Masood's men are threatening from the centres of Nahrin in the east and Doshi to the south.

Closer to the capital, fighting between commanders of Rabbani's Jamiat-e-Islami faction has teft more than $8 \rho$, mounded on both sides, an, unknown number of dead, and closed the main north-bound highway to regular traffic.

After three days of this fighting around the district headquarters of Mir Bachakot, some 30 kilometres (18 miles) north of Kabul, a temporary ceasefire was holding for the second day Tuesday, but locals and fighters were digging trenches in anticipation of more bombardments.

Me nnwhile, in Kabul, shopkeepers were told to hoist green flags to celebrate the upcoming second anniversary of the so-called "Islamic Revolution" in Kabul.

Not all shopkeepers are happy with the order because there has been no peace since the mujahideen's capture of Kabul in April 1992.

In addition to the massive killings of civilians, hundreds of thousands of people have been made homeless

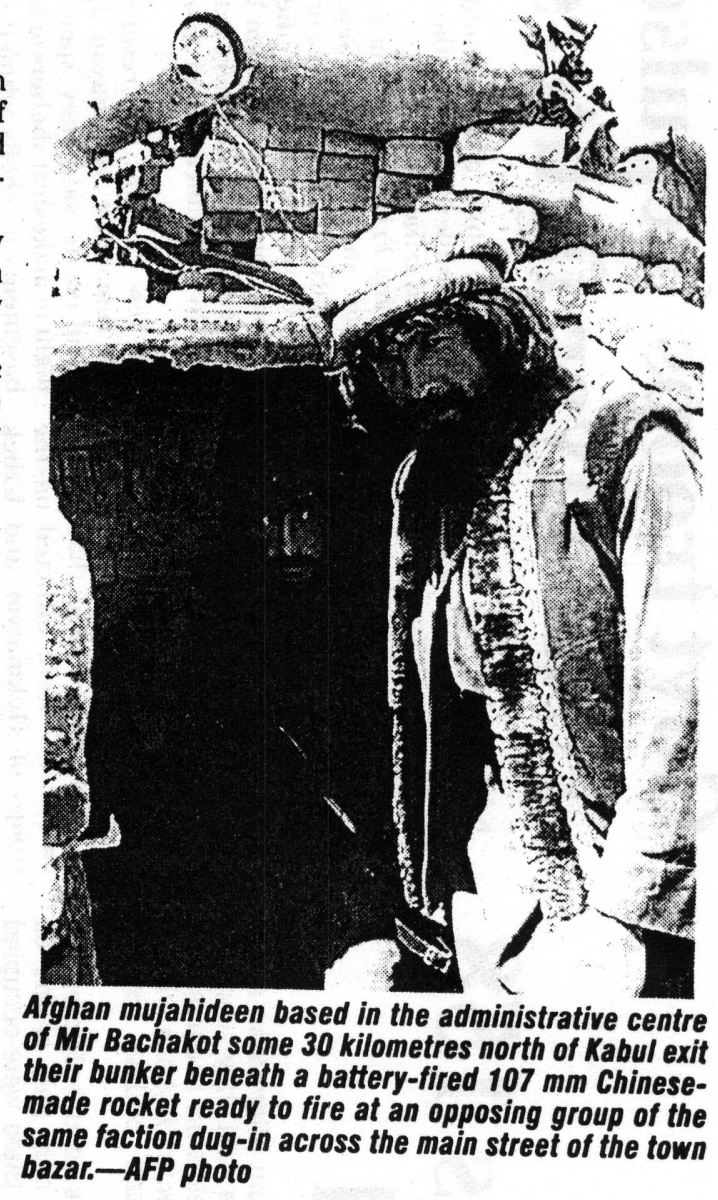

and most of the city's essential services have been destroyed.

"You don't need to be a clergyman to know the things the mujahideen leaders are doing in the name of Islam are wrong," said one shopkeeper, who described himself as a Muslim.

\section{Death toll in Kabul fight reaches 2,500: ICRC}

\section{0 wounded in Kabul factions clashes}

KABUL (AFP) - At least 140 civilians were wounded Thursday as fighting continued between Shiite guerillas and Afghan President Burhanuddin Rabbani's forces here for the second day.

Some 42 civilians were admitted to Wazir Akbar Khan hospital while 27 casualties were brought to the main Jamhuriat Hospital by late afternoon.

Another 37 people with bullet and sharpenal wounds were admitted to Aliabad hospital while 34 more casualties went to Karte Se hospital in war-torn Karte Se, doctors said.

By late afternoon the situation became calmer and shooting almost stopped, but roads to south Kabul were closed to vehicles.

The number of people killed was not known as hospitals in Kabul do 


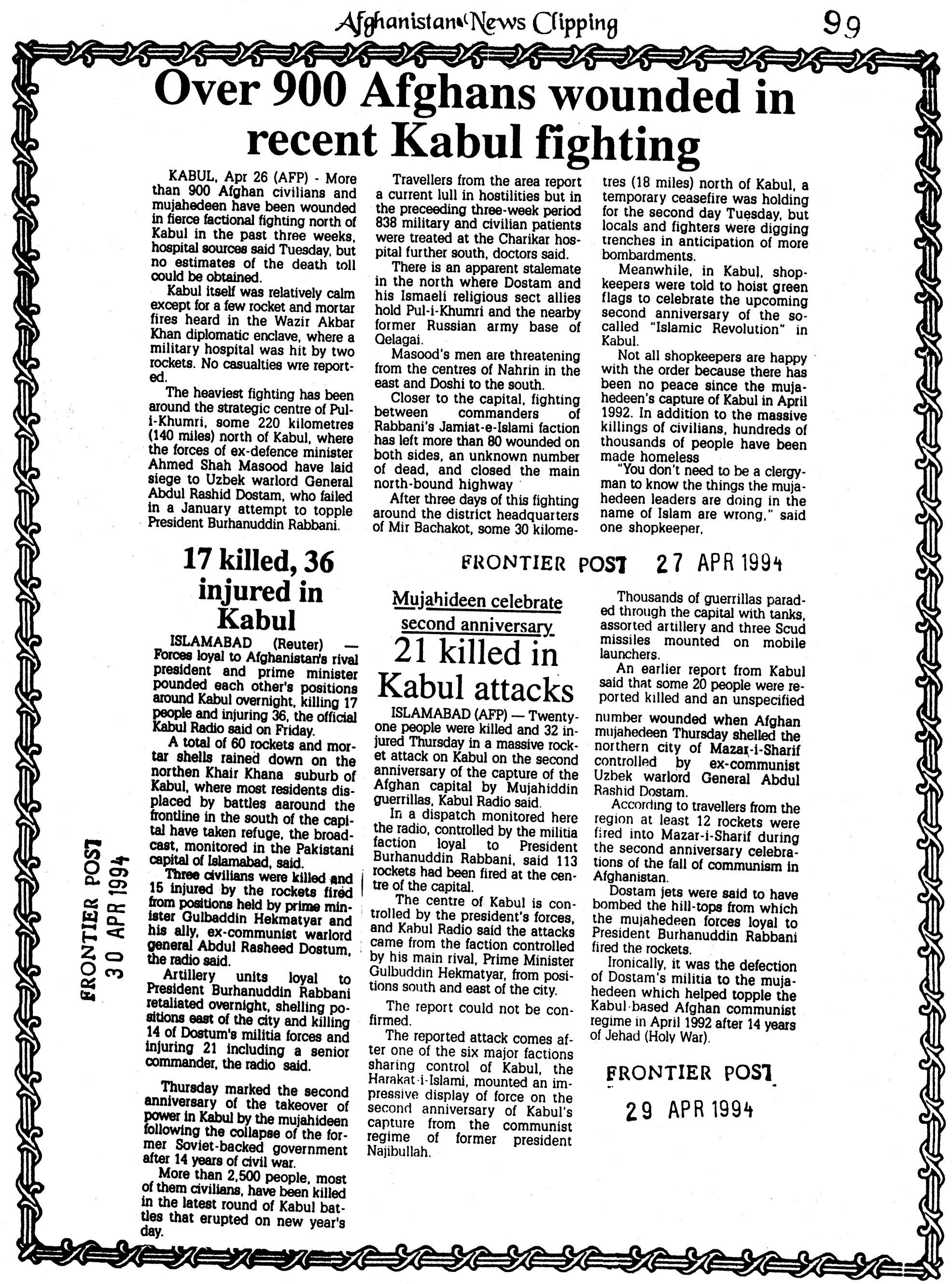


KABUL, April 6: The special UN envoy for Afghanistan left Kabul on Wednesday saying he had failed to win a conmitment for a ceasefire from Afghan President Burhanud. din Rabbani and his rival Prime Minister Gulbuddin Hekmatyar.

"I have not got a firm commit. ment from the conflicting sides for a lasting ceasefire," said Mahmud Mestiri, special envoy of the U.N. secretary-general, at the end of a five-day visit.

He said he planned to meet lead. ers of Afghanistan's provinces over the next two weeks to try to find a way of ending the fighting before returning to Kabul for final talks with the rival leaders.

Mestiri had two rounds of talks with Rabbani and met Hekmatyar at the prime minister's headquar. ters at south of Kabul to try to mediate an end to two years of factional warfare.

"We prefer a permanent cease fire to a temporary one - not only in Kabul but in all of Afghanistan," Rabbani told reporters after his talks with Mestiri.

The two sides had agreed to a ceasefire during the envoy's visit although clashes erupted in the Tagab Valley, about $65 \mathrm{~km}$ northeast of Kabul.

"I asked the leaders, especially the fighting sides to extend the ceasefire which has been holding during this visit," Mestiri told reporters.

"We think that Kabul must not return to the inhuman conditions of the past three months of war." -Reuter

\section{Kabul calm}

KABUL (AFP) - The frontlines of Kabul remained calm Thursday, even in the absence of an official extension of the temporary ceasefire, declared for the recent visit by United Nations peace brokers.

UN special peace envoy Mahmoud Mestiri left Kabul Wednesday afternoon for Islamabad without securing guarantees for a permanant peace in the war-ravaged Afghan capital where the current bout of factional fighting has lasted 14 weeks.

However Afghan Presidential spokesman Abdul Aziz Morad noted that a unilateral ceasefire, declared by President Burhanuddin Rabbani at Afghan New Year last week, was still in effect for another three days.

"The state supports not only an extended temporary Kabul ceasefire, but a permanent Afghan ceasefire," Morad added. reiterating remarks made by
Rabbani Wednesday, after the president emerged from his final session with Mestin.

But the UN still has to decide What its official role should be in the Afghan peace process. It is understood that part of the aim of Mestiri's visit was to reassess the Kabul security situation and make recommendations regarding the return of a permanent UN foreignstaff presence.

The UN, unlike the International Committee of the Red Cross (ICRC) and a handful of other foreign-based relief agencies who work in Kabul, has traditionally pulled out of the capital at the outbreak of any fighting.

Meanwhile a new peace semi. nar opened in Kabul Thursday. sponsored by the Islamic Brotherhood Front, just one of 14 Afghan peace organisations now trying to find a solution to the factional fighting
NATION

O 8 APR 1994

\section{UN fails to achieve Kabul ceasefire extension}

KABUL (AFP) - United Nations special peace envoy to Afghanistan Mahmud Mestiri returned to Pakistan Wednesday without gaining any strong commitment for an extension to a temporary ceasefire here.

"Till now we got no conckete promise regarding an acceptance for a permanent ceasefire," Mestiri told journalists. "We got promises and half promises to extend the ceasefire but I cannot say that we succeeded," he explained. Mestiri acknowledged that the warring factions in Kabul were happy to extend a ceasefire for the duration of the $U N$ peace mission visit, but he sad he was more concerned about what would happen after he left. Mestiri headed an eightstrong UN mission charged with examining the possibility peace in Afghanistan.

\section{APR 1994}

\section{NATION}

08 APR 1994

\section{DAWN}




\section{Kabul calm, but no permanent peace solution in sight}

KABUL (AFP) - Kabul was relatively calm Monday, with only sporadic shooting, as a solution to the 16-week-old Afghan factional fighting appeared nowhere in sight.

'There are many proposals, but no ultimate peace solution has been reached,' said presidential press spokesman Abdul Aziz Morad.

Morad again raised the unilateral ceasefire declared by President Burhanuddin Rabbani but said rival faction leader Prime Minister Gulbuddin Hekmatyar had not responded positively.

He added that an Islamic cleric's peace delegation that met with both Rabbani and Hekmatyar left Kabul Sunday without making any progress.
Locals in south Kabul reported two hours of fighting Sunday night between pro-Rabbani defenders of the central city mountain peaks and Hekmatyar's Shiite Hezb-i-Wahdat faction allies.

A Wahdat commander based below the strategic television tower on mountain peak said the fighting was a local affair, which erupted after a Wahdat guerilla accidentally stepped on a mine, blowing his leg off.

Pro-Rabbani military sources reported that Wahdat had attempted a small infantry assault against their peak but had been caught off-guard by the mines laid in defence of such an attack.

Although officially siding with
Hekmatyar in the armed struggle to unseat Rabbani, Wahdat leader Abdul Ali Mazari has yet to unleash his gunmen in the current bout of fighting, which has resulted in thousands of casualties and immense property destruction.

However, various members of Wahdat's central committee have recently been posturing for the return of the west Kabul district called Afshahr, which was captured by proRabbani troops more than a year ago.

Whether Wahdat uses the Afshahr issue as a pretext to go to war is not clear, but the extensive network of bunkers and trenches throughout southwest Kabul suburbs controlled by the Shiites shows their readiness for more fighting.

\section{NATION 19 APR 1994}

\section{Agreement \\ on truce in Kabul}

KABUL, April 13: Warring Afghan factions have agreed to a ceasefire in Kabul during a current visit by a peace mission of ulema the mission's leader said on Wed nesday.

Younis Khalis, who heads the group of religious scholars, told Reuters that President Burhanuddin Rabbani and his arch-enemy Prime Minister Gulbuddin Hekmatyar had undertaken not to fight during the mission's stay in the capital.

But forces controlled by Rabbani and by his opponents, led by Hekmatyar and powerful northern warlord General Abdul Rashid Dostum, traded sporadic artillery fire in central Kabul.

It was not clear how long the scholars, from Saudi Arabia, Pakistan, Bangladesh and Afghanistan itself, would stay in the war-shattered capital.

Khalis, who leads a faction of the
Afghanistan's Hezb-i-Islami party, met Rabbani in Kabul on Wednesday after arriving from the eastern town of Jalalabad and later said the president had pledged to cooperate with the mission.

Rabbani assured the ulema that his administration was ready for a permanent ceasefire, official Kabul Radio said.

The mission is yet to meet Hekmatyar, but Khalis said the prime minister, based at Charasvab south of Kabul, had given him assurances by telephone that he would observe the truce.

An earlier ceasefire agreed for

Related report on Page 14

the visit of a United Nations peace mission was shattered by artillery barrages on Sunday after holding for 10 days.

Government sources and doctors have reported more than 40 people killed and 250 wounded in the resumed factional fighting over the past three days. There was no immediate information about casualties in Wednesday's shelling. -Keuter 


\section{Highway closed after Kabul infighting} KABUL, April 24: Heavy-
weapons fighting on Sunday between rival factions of President Burhanuddin Rabbani's forces, about 30 kilometres north of Kabul, closed the national highway, according to reports from people passing through the area.

The fighting, now in its second day, occurred around the district centre of Mir Bachakot, a bazaar which traveller; saly has been badly damaged in the bombardment by Chinese-made $107 \mathrm{~mm}$ BM-1 roc kets.

At least 10 severely wounded people were evacuated to Kabul for medical treatment.

Information about the conflict was sketchy, but the battle was said to be between two regional commanders loyal to Afghin President Burhanuddin Rabbani.

A Defence Ministry official said the although the fight might be bet. ween two commanders of Rab. bani's Jamiat-i-Islami faction, it was more likely a personal affair than a party dispute.

"The fighting is a personal mat. ter. It could be for ethnic or geog. raphic reasons," said the Defence Ministry official. He asserted the use of heavy weapons did not necessarily mean the fighting was intense.

"Since these weapons are in the hands of the commanders, they do not hesitate to use them," the official said.

A peace delegation sent from Kabul was successful in quelling the fighting for a short while, but after they left the conflict flared again.

Meanwhile forces of Afghan President and fighters of a rival Shia group traded rocket and artil. lery fire in Kabul on Thursday, killing two people and injuring 42, hospitals said.

Three hours of exchanges of roc- ket and artillery fire rocked the war-shattered capital in the morning and doctors at Kabul's two main hospitals said they had admitted battles in the western suburbs.

Abdul Ali Mazari, leader of the Shia Hezb-i-Wahdat faction said the fighting raged despite a ceasefire agreed earlier between his party and officers of Rabbani's gov. ernment forces.

Both sides were trying to enforce the latest fragile ceasefire, due to take effect mid-morning, but their efforts were hampered by sporadic shelling throughout the afternoon, Mazari said in an interview.

At least 33 people were injured in artillery and small arms fire between government forces and Hezbi-Wahdat on Wednesday.

The clashes were the first between Rabbani's forces and the Hezb-i-Wahdat in nearly four months of factional fighting in Kabul.

Much of the latest fighting was concentrated around Kabul Uni versity, a main base for Hezb-i Wahdat in a city divided into a patchwork of fiefdoms controlled by guerillas of the various quarrel. ling parties in the two-year-old Islamic coalition government.

A peace mission consisting of two officials from each side had been set up to monitor the ceasefire, Mazari said.

Wahdat is an ally of Rabbani's arch-foe Prime Minister Gulbuddin Hekmatyar but has stayed away from the current factional fighting in which more than 2,000 people have been killed since it erupted on the New Year's Day.

Wahdat wants back the Afshar area west of Kabul that it lost to pro-Rabbani forces last year. Both sides have been digging trenches within 10 metres from each other.-Reuter two dead and 42 injured after the

\section{Kabul fighting cuts national highway}

KABUL (AFP) - Heavy. weapons fighting Sunday between mujahedeen commanders 30 kilometres (20 miles) north of Kabul closed the national highway, according to reports from people passing through the area.

The fighting, now in its second day, occurred around the district centre of Mir Bachakot, a bazaar which travellers say has been badly damaged in the bombard. ment by Chinese-made $107 \mathrm{~mm}$ BM-1 rockets. At least 10 severely wounded people were evacuated to Kabul for medical treatment.

Kabul, however, has remained relatively calm.

Information about the conflict is sketchy, but the battle is said to be between two regional com. manders loyal to Afghan President Burhanuddin Rabbani

A Defence Ministry official said the although the fight might be between two commanders of Rabbani's Jamiat-i-Islami faction. it was more likely a personal affair than a party dispute.

"The fighting is a personal matter. It could be for ethnic or geographic reasons," said the Defence Ministry official. He asserted the use of heavy weapons did not necessarily mean the fighting was intense.

"Since these weapons are in the hands of the commanders, they do not hesitate to use them," the official sajd.

A peace delegation sent from Kabul was successful in quelling the fighting for a short while, but after they left the conflict flared again.

In Kabul Sunday, there was calm for a second day; the front lines were quiet and civilians moved freely without fear of in. coming rockets.

ERONTIER POST

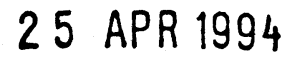




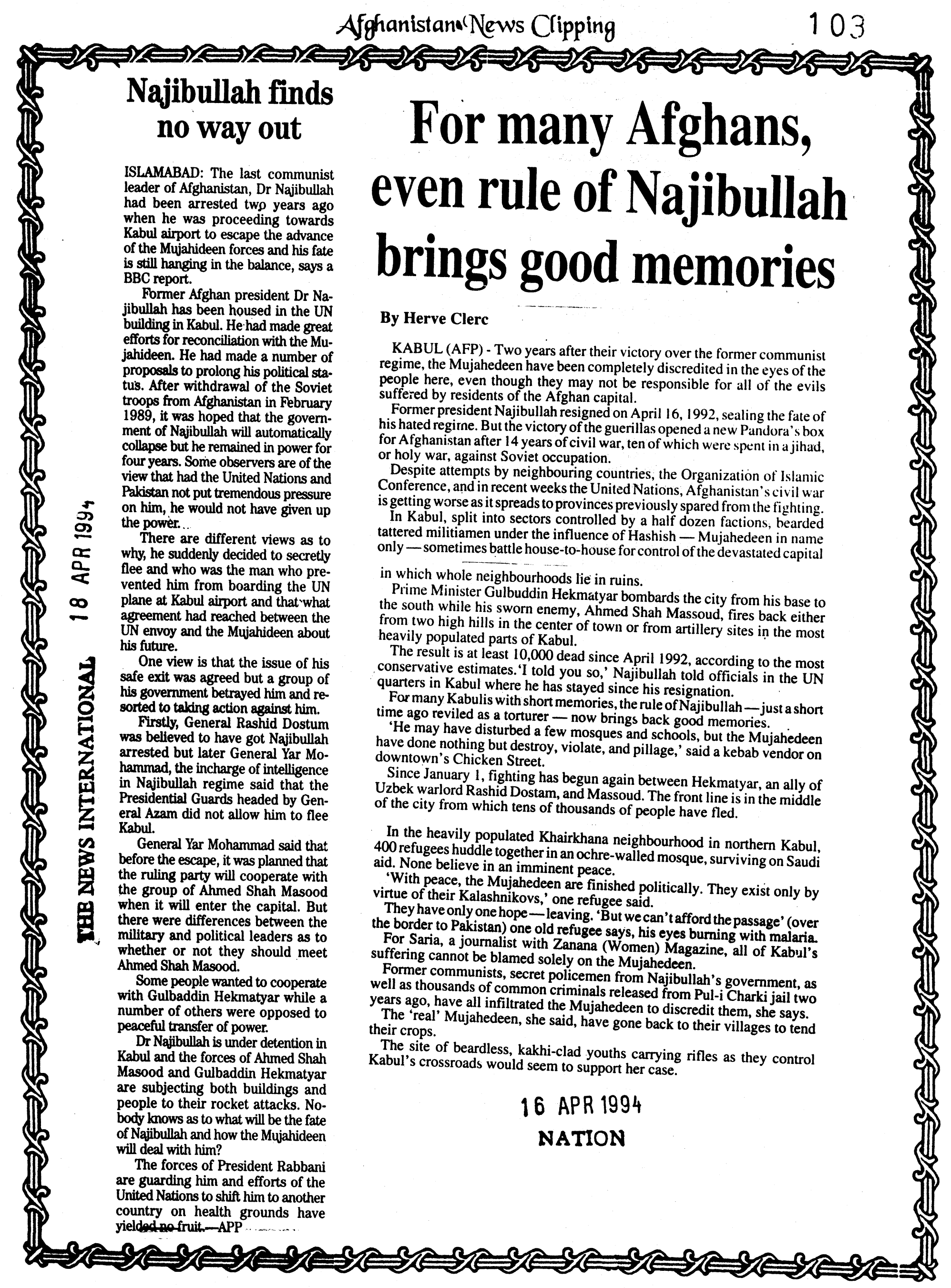




\section{Bureau Report}

PESHAWAR: Five Pakistanis, three Iranians and one Tajik along with former Afghan communist leaders, Asadullah Sarwari, Gen Juma Achak and Gen Baseer Pilot, are languishing in prisons run by the Rabbani government in Kabul and Panjshir valley.

This was revealed by Asadullah Habib - an Afghan who supported the Hezb-i-Islami and was caught in Kabul to spend the next eight months in different prisons.

About the five Pakistani prisoners, Asadullah Habib recalled one named Shabbir Ahmad hailing from Peshawar. The names of the remaining four he couldn't ascertain as they all spoke Urdu. He said he met them at the jail number three in Kabul. He informed that two of the three Iranians were named Khisro and Ali. He also met Tajikistan's Bahadur. All were accused of spying against the Rabbani government.

Talking to The News in Peshawar, he said he met Sarwari and Juma Achak in a makeshift prison in Sufaid Chehr in Panjshir Valley and learnt about their ordeal.

Sarwari, a noted PDPA leader who was declared "butcher of Kabul" after reports that he sum. marily executed prisoners and suspects and subjected them to worst kind of torture. Since he was a Khalqi, Sarwari fell from grace due to differences with the Parchamdominated Afghan government and fled to India. Subsequently, he was arrested in New Delhi by the Indian authorities following complaints by Dr Najibullah's government. He was nabbed when he returned to Kabul in the wake of the installation of a mujahideen government and declaration of general amnesty.

Asadullah Habib said Sarwari told him that men belonging to Masood's Shura-i-Nazar picked him up from his home in the Microryan housing estate only 20 days after his voluntary return to Kabul.

However, Sarwari didn't complain to him about maltreatment at the hands of his captors. Sarwari over the past two years has kept a long beard and greyed a bit. He was seen carrying prayer beads all the time.

Gen Juma Achak, commander of all Afghan troops in northern Afghanistan, told Asadullah Habib that he too was in jail for the two years. He has also grown a beard and become a religious person. It was Gen Juma Achak's transfer to Mazar-i-Sharif as head of the Afghan Army's northern command that sparked a rebellion by Gen Rasheed Dostum, Gen Momen, Gen Mansoor Naderi etc., against President Na. jibullah and led to the downfall of the latter's government.

Gen Baseer is the pilot of the plane which was shot down by the Rabbani-Masood forces recently. Hailing from Kama in Nangarhar province, Gen Baseer was loyal to Gen Dostum's Junbush-i-Melli Islamic Afghanistan.

Asadullah Habib narrated how the prisoners were tortured and denied basic rights. "Once I was beaten up for five and a half hours by seven persons and my nails were pulled out," he recalled.

He said the in charge of the jail number three in Kabul, Kararuddin, excelled in torturing PoWs and drew pleasure at their predicament. He said the condition at the prisons in Kabul and in Baharak, Khenj and Sufaid Chehr were terrible due to overcrowding, inadequate food and lack of cleanliness. He added that President Rabbani's orders for release of prisoners were seldom implemented while his former defence minister Ahmad Shah Masood's word was final.

The bearded Asadullah Habib said people like Sarwari and Juma Achak were given a better treatment in prison and allowed to receive visitors and access to the radio and television. He recalled that Gen Yunis Qanuni, an important leader in Rabbani's Jamiat-i-Islami, and a former government official, Wakil Qayyum Panjsheri, had met Sarwari in prison.

Asadullah Habib informed that he was freed a day before Eidul Fitr in an exchange of prisoners between President Rabbani and Prime Minister Hekmatyar. He said he decided to come to Pakistan as he no longer felt secure living in Kabul. He said he and other prisoners were made to carry sacks of wheat, atta, sugar, vegetables and ammunition on their backs to Panjshir.

$\mathrm{He}$ recalled how people in $\mathrm{Ba}$. harak and Khenj hit the prisoners with snow amid anti-Hekmatyar anc anti-Dostum slogans. "The five and a half years I spent earlier in prison during communist rule were better than the eight tortuous months 1 spent in the Rabbani government jails," he remarked. 


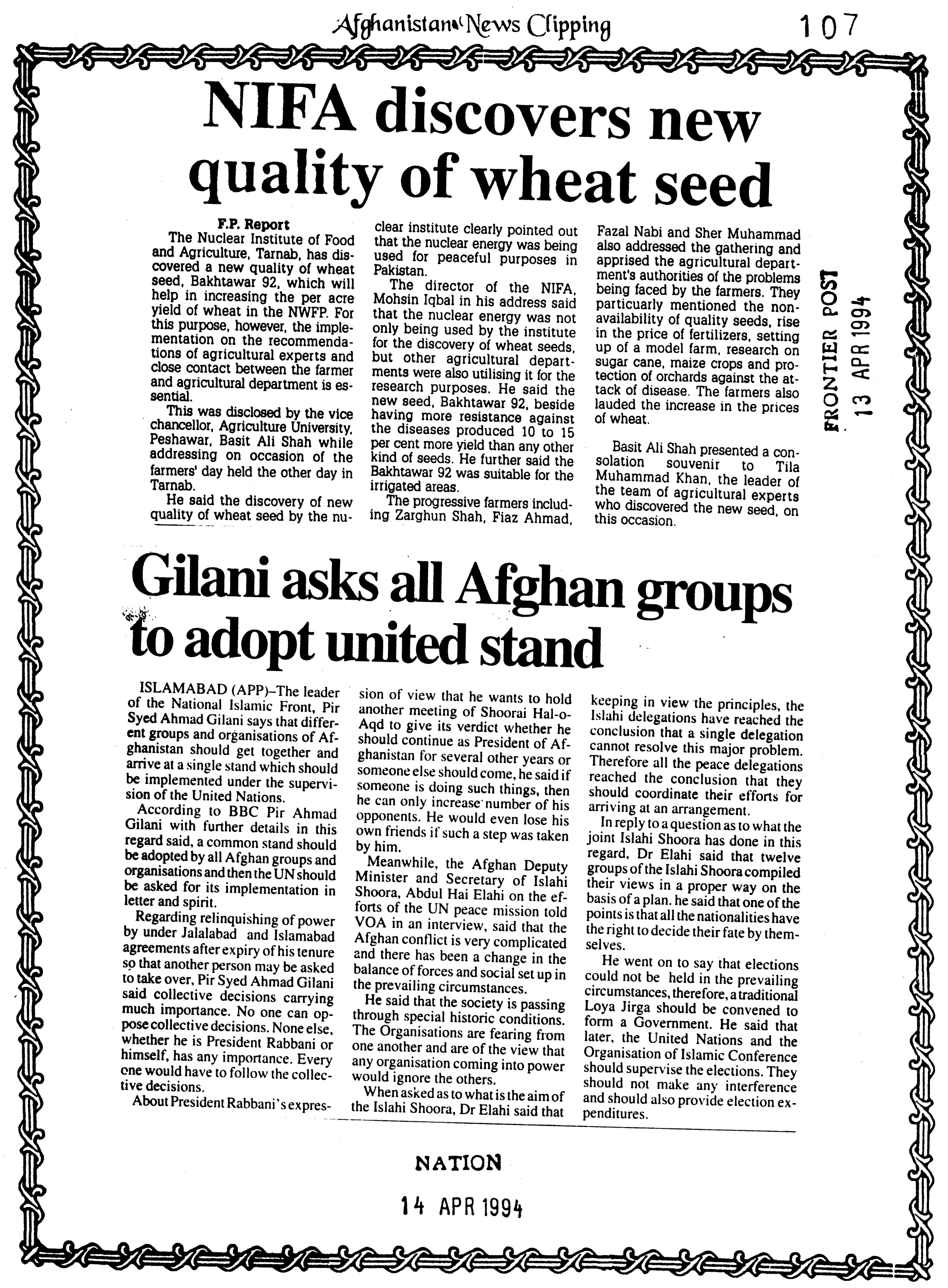




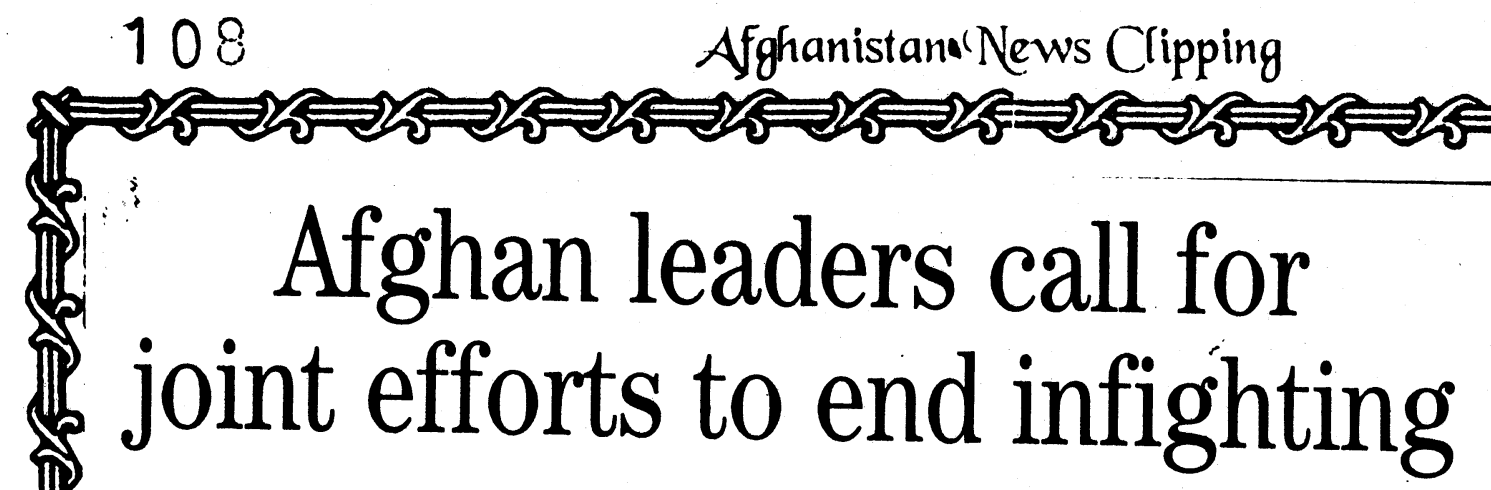

\section{APP}

ISLAMABAD: The leader of Afghanistan's National Islamic Front, Pir Syed Ahmad Gilani, has called upon different Afghan groups and organisations to get together and take a united stand to be later implemented under the supervision of the United Nations.

According to BBC, Pir Ahmad Gilani said a common stand should be adopted by all Afghan groups and organisations, and then the UN should be asked for its implementation in letter and spirit.

About President Rabbani's desire to hold another meeting of Shoora-i$\int \mathrm{Hal}-0$-Aqd to give its verdict whether he should continue as pres- ident or someone else should take over, he said that if someone was doing such things, he could only increase number of his opponents. Rabbani would even lose his friends if such a step was taken, he added.

Meanwhile; Afghan Deputy Minister and Secretary of Islahi Shoora Abdul Hai Elahi, commenting on the efforts of the UN peace mission, told VOA in an interview that the Afghan conflict was very complicated and there had been a change in the balance of forces and social set up in the prevailing circumstances.

About the aims of the Islahi Shoora, Dr Elahi said that keeping in view the principles, Islahi delegations had drawn the conclusion that a single delegation could not resolve this major problem. Therefore, all peace delegations were now coordinating their efforts to reach an agreement, he said.

Dr Elahi said 12 groups of the Islahi Shoora compiled their views on the basis of a plan. He said one of the points was that all nationalities had the right to decide their fate and that elections could not be held in the prevailing circumstances.

He called for a traditional Loya Jirga to be convened to form a neutral government.

He said that the United Nations and the Organisation of Islamic Conference should supervise the elections. They should not make any interference and also provide election expenditure.

\section{NIFA chief for UN role in achieving Afghan peace}

ISLAMABAD (APP) - The leader of the National Islamic Front Afghanistan, Pir Syed Ahmad Gilani says different groups and organisations of Afghanistan should get together and arrive at a single stand which should be implemented under the supervision of the United Nations. According to BBC Pir Ahmad Gilani said a common stand should be adopted by all Afghan groups and organisations and then the UN should be asked for its implementation in letter and spirit.

Regarding relinquishing of power under Jalalabad and Islamabad agreements after expiry of the tenures of the incumbent rulers so that another person may be asked to take over, Gilani said collective decisions carry much importance. "No one can oppose these. No one, whether he is president. Rabbani or myself. has any importance. Everyone would have to follow the collective decisions", he said.
About Rabbani's statement that he wants to hold another meeting of Shoorai Hal-o-Aqd to give its verdict whether he should continue as president of Afghanistan or someone else, Gilani said this way Rabbani can only increase the number of his opponents. he would even lose his own friends if such a step was taken by him, he said.

Meanwhile, the Afghan deputy minister and secretary of Islahi Shoora, Abdul Hai Elahi on the efforts of the UN peace mission told VOA in an interview that the Afghan conflict is very complicated and there has been a change in the balance of forces and social set up in the prevailing circumstances.

He said the Afghan society is passing through a critical juncture in its history. The different parties fear one another an dare of the view that any one of them coming into power would ignore the others, he said.

Asked what is the aim of the
Islahi Shoora, Dr Elahi said Islahi Shoora delegations have reached the conclusion that a single delegation cannot resolve the major problems. Therefore they should coordinate their efforts for arriving at an agreement.

In reply to a question as to what the joint Islahi Shoora has done in this regard. Dr Elahi said its 12 groups name compiled their views in a proper way on the basis of a plan. he said one of the points is that all the nationalities have the right to decide their fate by themselves. He went on to say that elections could not be held in the prevailing circumstances, therefore, a traditional Loya Jirga should be convened to form a government. He said later, the United Nations and the Organisation of Islamic Conference should supervise the elections. They should not make any interference and should also provide election expenditures, he added.

\section{Mujaddedi calls for peace back home}

\section{Bureau Report}

PESHAWAR: The former president of Afghanistan and leader of Afghan National Front, Prof Sibgatullah $\mathrm{Mu}$ jaddedi, has appealed to all Afghan religious scholars, mujahideen leaders and tribal elders to get united and stop bloodshed in the already devastated country.

In a message on occasion of the second anniversary of mujahideen's takeover of power in Afghanistan on April 28, 1992, he said unity was the only way out of the present quigmire and saving the country from death, destruction and power lust.

He regretted irresponsible and unwise measures in state and military? affairs by Prof Rabbani after assuming office. He said the rights of other organisations were ignored, administrative and political posts were dis-? tributed on basis of linguistic, ethnic and organisational discrimination anc lives and property of people wer made insecure.

Recalling his two-month rule as president, he had succeeded in solv ing a number of problems of the peg) ple and restoring peace.

FRONTIER POST

14 APR 1994

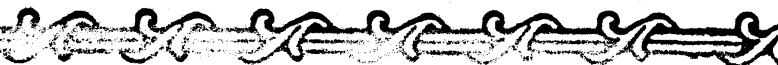




\section{'High time for Afghans to move for peace'}

\section{From Shamim Shahid}

PESHAWAR - Chief of Nationa Islamic Front of Afghanistan, Pir Syed Ahmad Gillani has said that his party wanted an amicable settlement to the Afghan conflict in the light of aspirations of the majority of Afghans, and in this regard an emergency meeting of the traditional Loya Jirga will play a vital role.

He expressed these views while talking to The Nation, after holding a meeting with the United Nations Secretary General's special representative, Mehmood Mestiri on Saturday afternoon. Ahmad Gillani termed his talks fruitful with Mestiri and welcomed the United Nations efforts. He assured full support to the United Nations team in its efforts for resolving the Afghan conflict.

The front chief said that people of Afghanistan have rendered tremendous sacrifices for liberation during 14-year long jehad and it was high time that these people should be allowed to determine fate of their country and people. Therefore, it is essential to convene an emergency meeting of the traditional Loya Jirga for the formation of a broad-based interim government. He said that this process should be completed before completion of Prof Rabbani's tenure, so that he could transfer power to the interim government.

Referring to his talks with MehmoodMestiri, Pir Ahmad Gillani said that United Nations was striving for a consensus amongst the Afghans and to enable them for resolving their problems according to their own traditional ways. He was of the view that Afghanistan and its people could be pulled out of existing crisis with formation of a government acceptable to the majority of Afghans.

Gillani said that he presented his party's proposals and suggestions for

\section{NATION \\ 10 APR 1994}

resolving the conflict to the United Nations Secretary General. He said that he had told Mehmood Mestiri that United Nations should extend help to the peace-loving Afghans in formulation and convening of the emergency meeting of the traditional Afghan Loya Jirga.

Referring to functions and duties of the emergency Loya Jirga, Pir Syed Ahmad Gillani said that along with formation of an interim government, the Loya Jirga will focus on formation of a national army, security force and other institutions for restoration of peace and establishing a centralised authority in Afghanistan. He also said that in a fix period, the Loya Jirga will frame a national constitution and will make arrangements for holding of impartial general polls in the country. When asked about the success of the UN's team, Ahmad Gillani said that all these efforts are useful for Afghans and responsibility rest with Afghans from every sphere of life to extend due cooperation to the United Nations team for building up a consensus amongst the Afghan leadership.

\section{Former Afghan president meets Leghari}

ISLAMABAD: Former Afghan president and a leader of the Afghan National Liberation Front, Prof Sibghatullah Mujadidi, called on President Farooq Ahmad Khan Leghari and held a wide ranging discussion with him, says a press release here Tuesday.

Speaking of the prospects of peace in Afghanistan President Leghari emphasised that this will have to be an indigenous process as anything imposed from outside would never last.

The president also expressed the hope that the developed countries would not wait for complete peace to being reconstruction work in Afghanistan. A beginning could be made in the peaceful areas and this itself would be an inducement for peace.
Resignations key

to Afghan peace:

\section{Mujaddedi}

ISL AMABAD (APP) - The head of National Salvation Front of Afghanistan, Sibghatullah Mujaddedi has s:id that the present situation in Afghanistan is very deplorable.

In an interview with Voice of America, Prof. Sibghatullah Mujaddedi said that people are suffering at the hands of Muslims, becatise neither there are Soviets nor coimmunists to do so. He added that he has tine and again presented proposals for the solution of the existing situation, but his proposals were not implemented.

Mujaddedi said that key to the solution of the problem lies in the resignation of Rabbani and Hekmatyar. He said. hoth the leader have been unable to restore law and order in Afghanistan during their tenure

Professor Mujaddedi expressed the hope that cease-fire would come into effect on the very day of their tendering resignation. "I had already proposed that either a special meeting, conference, jirga or seminar representing the nation should be convened. He said that they should authorise the people of Afghanistan to decide their future President and interim Government. He added that elections should be held after restoration of stability in Afghanistan.

\section{NATION}

\section{APR 1994}

NATIUN

21 APR 1994 


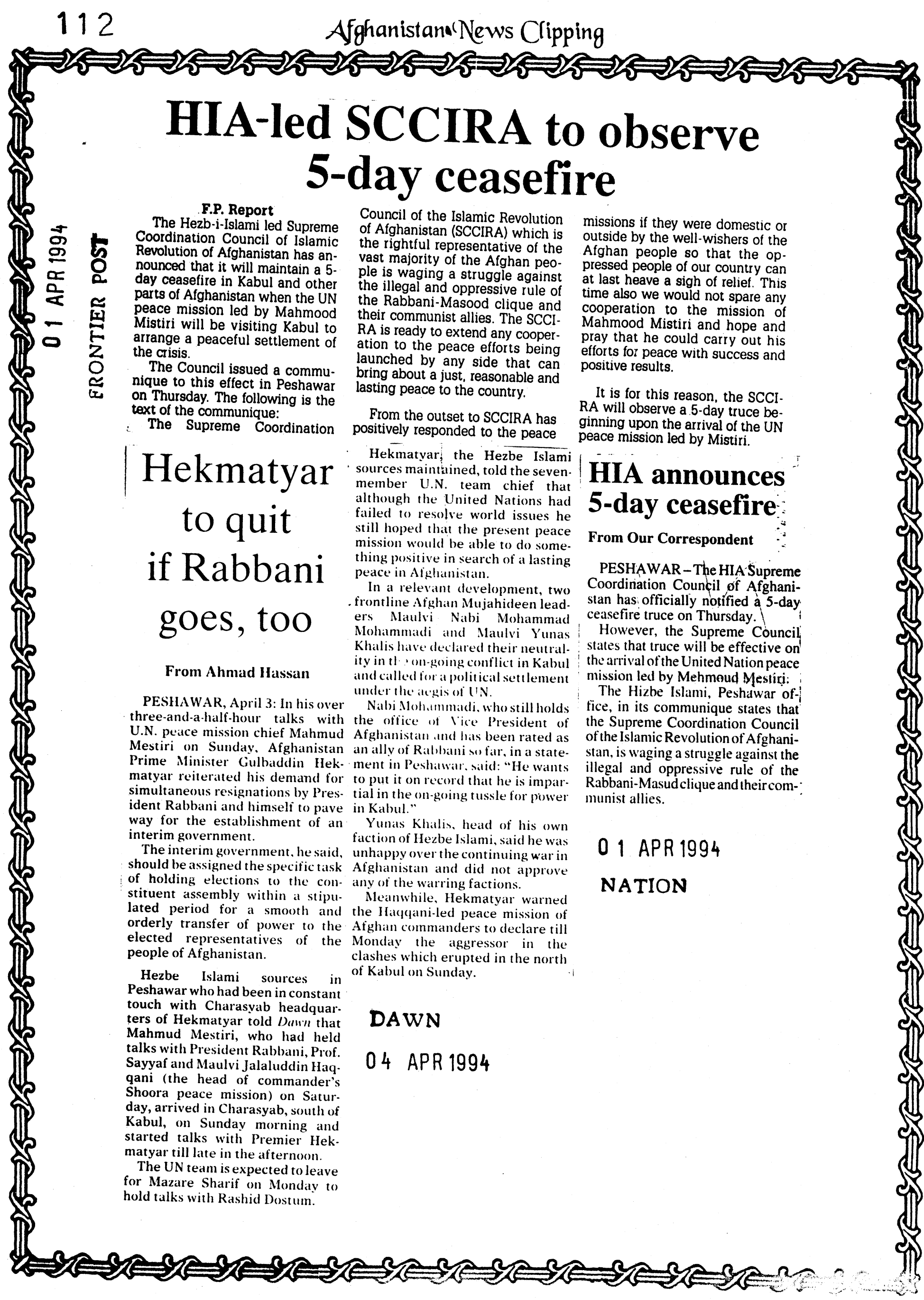




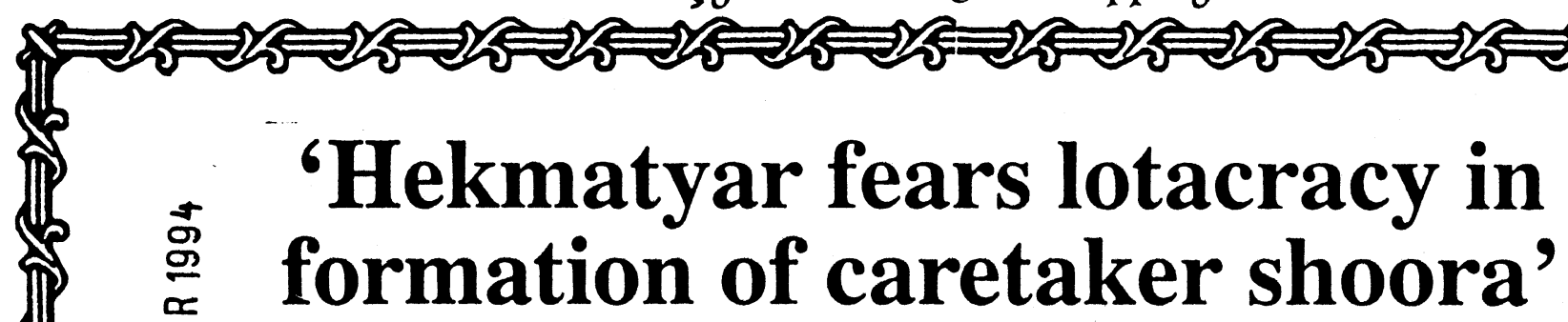

7.P. Report

"Afghan Premier Gulbaddin Hekmatyar fears lotacracy in the formation of the caretaker Shoora responsible for forming interim government, and has suggested that Afghan leaders should set up the caretaker government, instead", said Maulana Hassan Jan while talking to journalist on his return from Afghanistan at Peshawar Press Club Monday.

Maulana Hassan Jan was heading Pakistani ulema of the peace mission. The team comprising religious leaders from Afghanistan, Saudi Arabia and Pakistan was led by Maulvi Muhammad Yunis Khalis, chief of his own faction of Hizb-i-Islami.

He said while both the major Afghan factions had agreed to a four-point formula to end the crisis, there persisted some differences which would automatically and after some time. He added

KABUL (Reuter) - Afghan Prithe Minister Gulbuddin Hekmatyar told a UN peace mission on Sunday that the resignation of President Burhanuddin Rabbani was the only way to end two years of factional battles that have killed 11,000 people.

"The solution for Afghanistan is Rabbani's unconditional resignation, formation of an interim government in which the mujahideen leaders should not participate", Hekmatyar said after more than three hours of talks with mission leader, former Tunisian foreign minister Mahmoud Mestiri.

He said elections and tive with drawal of all heavy guns from around Kabul were also prerequisites to end rocket and artillery battles that have forced tens of thousands of Kabul residents to flee their homes and left large areas of the city in ruins.

"I am optimistic", Mestiri said after the talks at Hekmatyar's heavily fortified base in Charasyab, about 20 kilometer southeast of Kabul. that a reconciliatory committee headed by Commander Jalaluddin Haqani would remain in touch with various leaders in Afghanistan and try to resolve the issue as soon as possible.

He avoided to answer when asked as to whether the ulema would pass a Fatwa against the Afghan leaders Burhanuddin Rabbani and Gulbaddin Hekmatyar who killed thousands of innocent people in the struggle for power.

Maulana, Abdur Rahim Chitrali, Jamat-i-Islami MNA, said that the Afghan leaders were being instigated by the communist and western forces to fight each other. He added these lead. ers could not be blamed entirely for the massive killings in Afghanistan. He said that "if you want the Fatwa against the western forces or communists, we will

issue it".

Maulana Hassan Jan said Rabbani had suggested setting up of a caretaker Shoore which would name neutral persons for the interim setup in Kabul. He quoted Rabbani as saying that the interim government would chalkout strategy for establishing a permanent national government in the country. According to Gulbaddin Hekmatyar, he said there was no need of the caretaker Shoora and the interim government should be formed by the leaders of various Afghan factions.

The Maulana also explained other points which were approved by the Afghan leaders. They are: permanent ceasefire in Afghanistan, opening of roads leading to various areas and removed of combatant forces from Kabul to be replaced by neutral forces of Jehadi commanders.

\section{Rabbani's resignation only way to peace: Hekmatyar}

Mestiri met Rabbani on Saturday and said he had obtained a clearer view of the president's position but was unable to say if he had made progress toward a lasting peace.

Mestiri said he had agreed with Hekmatyar that a group of mujahideen commanders not af-

filiat ied with the main warring parti 3 s should try to formulate a peace : plan within the next few days.

"We both are optimistic about a lastin/ y ceasefire", Mestiri said. "The $r$ jeasefire is generally holding and I hope it could be extended indefinitely.

Both Rabbani and his arch-rival Hekmatyar, who launched his latest battle to topple the president on January 1 , agreed to a ceasefire during the visit by the fivemember UN mission.

"I prefer a permanent ceasefire to a limited one", Hekmatyar said. "The ceasefire announced for the duration of the visit could be ex- tended if the other side takes positive steps".

However, he accused Rabbani's forces of breaking the ceasefire by opening fire on the prime minister's forces in the Tagab valley about 65 kilometre northwest of Kabul - the scene of fierce battles between the two leaders late last year.

"While I am speaking to Mestiri military base was attacked by rockets", Hekmatyar said.

\section{FRONTIER POST}

04 APR 1994 


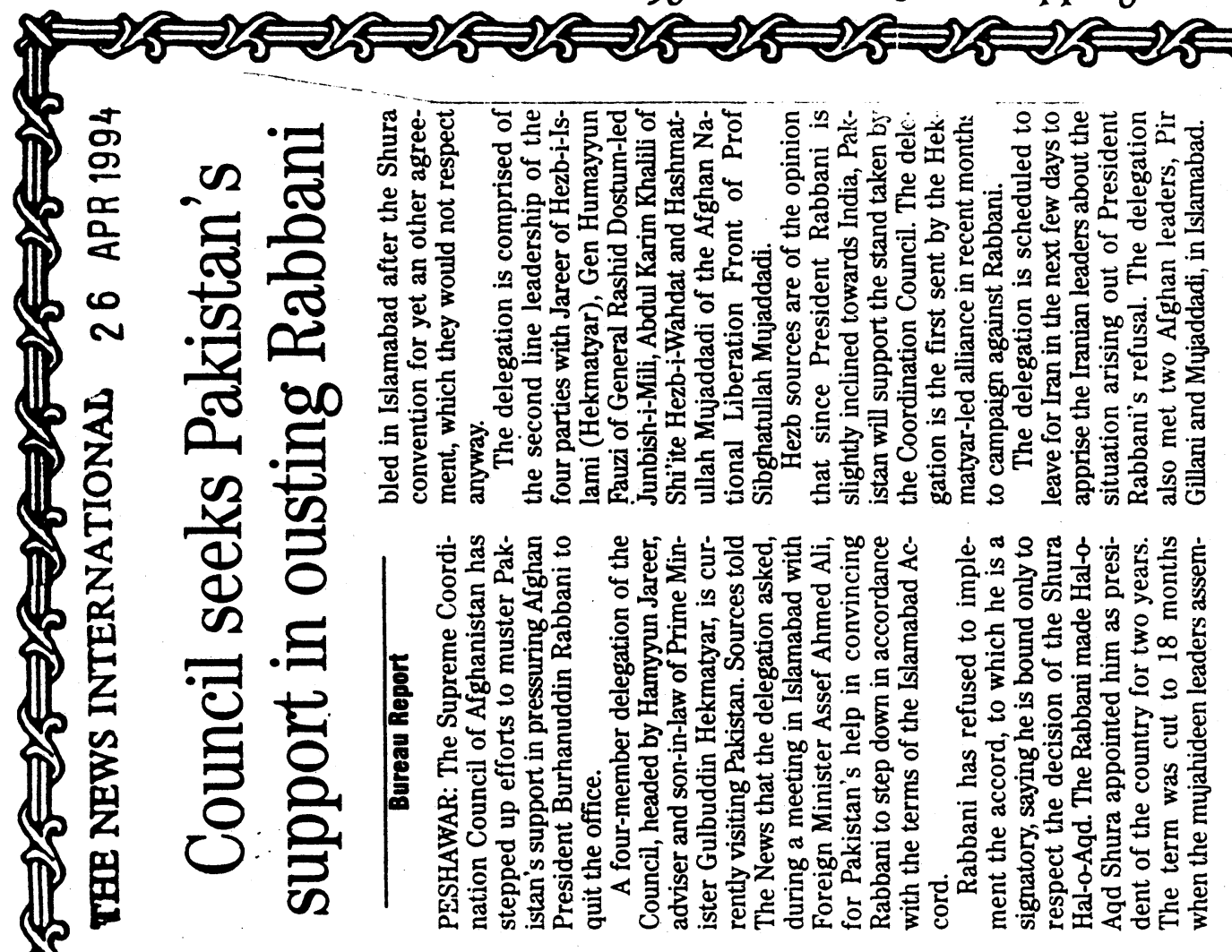

HIA denies report

F.P. Report

A spokesman of Hizt-i-Is!ami Afghanistan, Nawab Saleenr" Tuesday denied a news item published in The Frontier Post regard ing Prime Minister Gulbuddin Hikmatyar's appeal to government of Pakistan to lift ban on transshipment of Afghan goods, including tyres and tubes.

He said the news item was absolutely baseless and such a statement had been issued neither by him nor his office in Peshawar.

The news item stated that Hekmatyar had in a press statement, appealed to Prime Minister Benazir Bhutto to take effective measures for lifting ban on transshipment of tyres, tubes and oth. er Afghan goods.

The spokesman stated that some other people might fake letters in the name of Afghan premier or the HIA.

FRONTIER POST

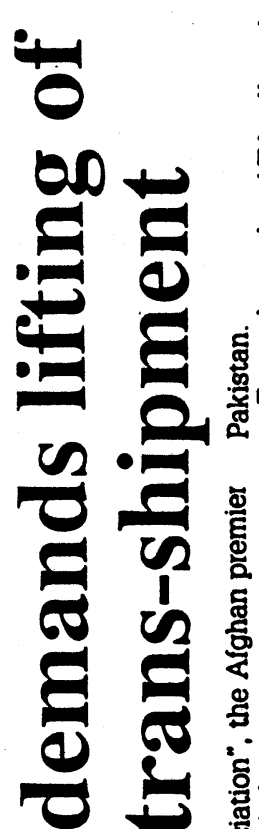

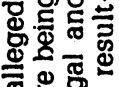

s:pe

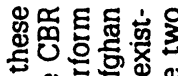

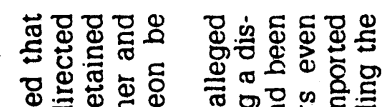

更

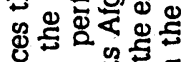

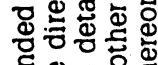

政

要

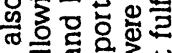

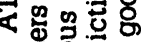

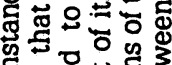

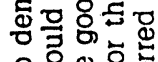

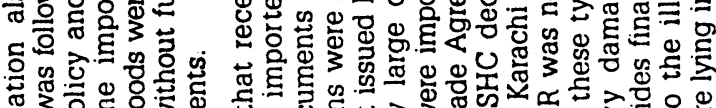

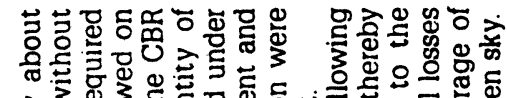

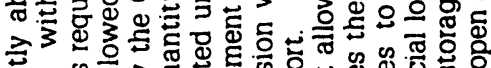

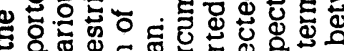

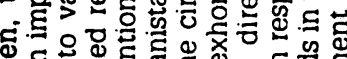

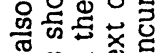

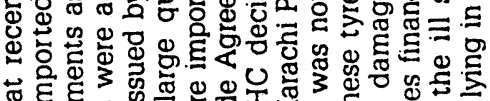
象元

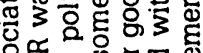

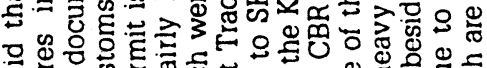

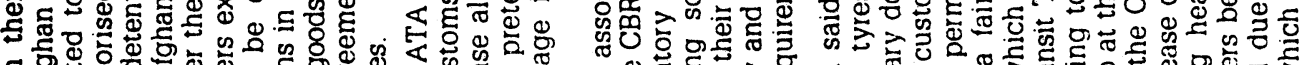

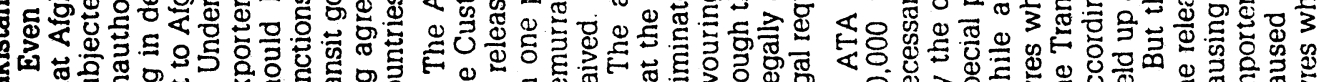

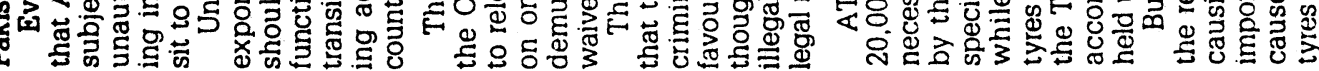

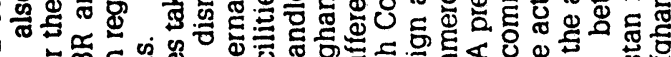

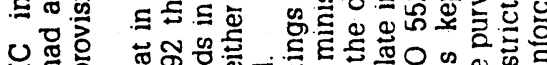

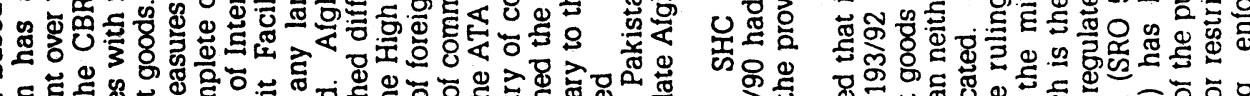

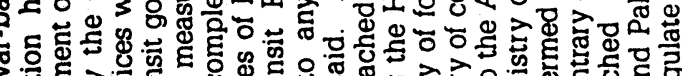

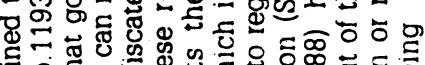

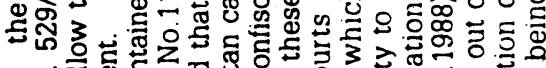
ర్d

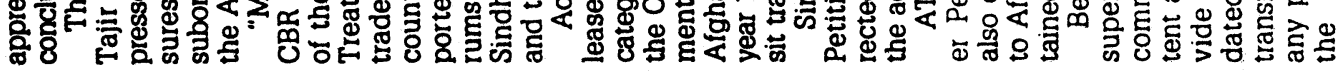

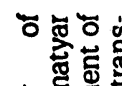

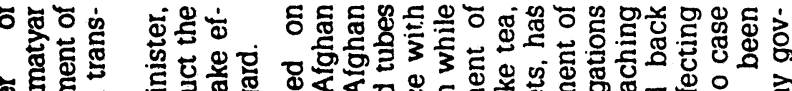

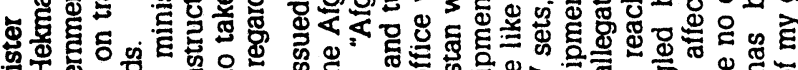

现

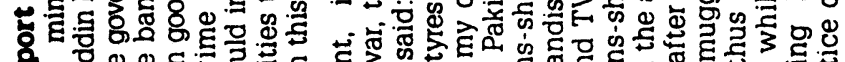

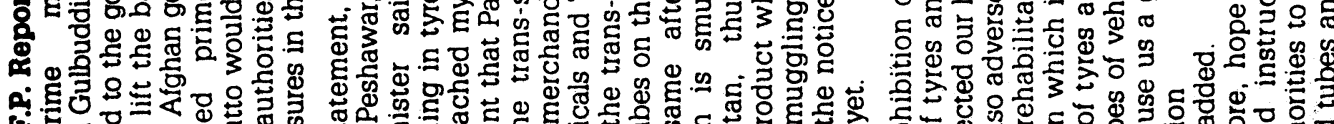

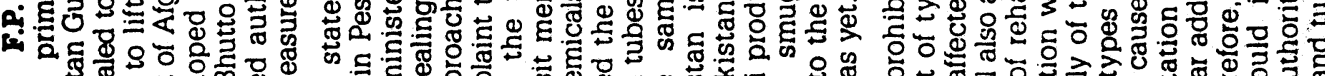

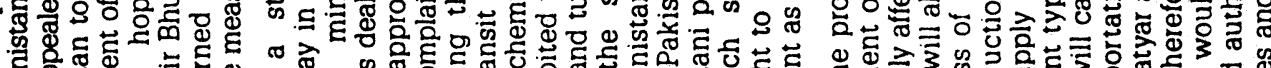

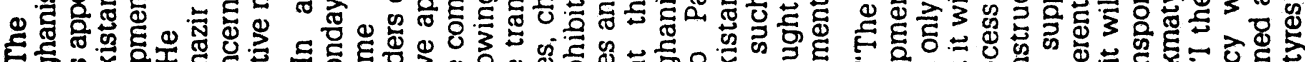

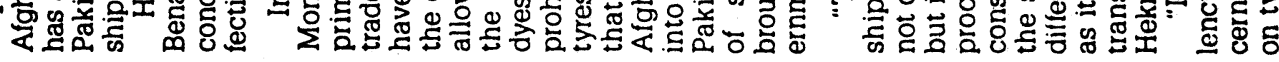

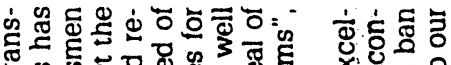

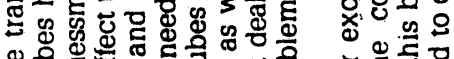

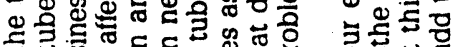

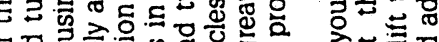

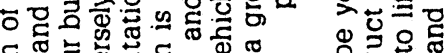
ธ。 1 a) ar 


\section{Bureau Report}

PESHAWAR: 'Da Afghanistan Da Sulhe Mubaarizin', an organisation struggling for reconciliation in the war-torn country, Monday asked the UN special envoy on Afghanistan Mehmud Mestiri to take practical steps for bringing permanent peace and help setup a government representing all segments of the Afghan society.

Addressing a press conference at Peshawar Press Club, Shan Badshah, the organisation's vice president said foreign powers were interfering in Aighanistan to promote their vested interest. Such interference, he said, would have to be stopped to restore lasting peace in that country.
He urged the world body to play its due role in accordance with the United Nations resolutions on Afghanistan and restore peace and order and stressed that the Afghans be given representation in negotiations to help form a consensus government acceptable to all, as the Afghans, he warned, would not accept any government imposed on them from the outside.

He accused certain mujahideen leaders of bring bad name to the traditional loya jirga and claimed that the same people were trying to convene a jirga devoid of representation.

The Afghans, he said, would not accept any jirga lacking in representation and national character.

\section{Ittehad Islami denies naming Rocketi as governor}

QUETTA: Ittehad Islami Afghanistan has strongly denied that it has neither nominated Mulla Salam Rocketi as governor for Zabul province of Afghanistan nor it supports terrorist activities against Pakistan by any of its member.

In a statement here Wednesday political director Baz Muhammad said that at present Zabul governor is Sidiqullah. There is no truth in the report that Mulla Rocketi has been appointed as governor Zabul province.

The statement maintained the governor for Zabul or any other province of Afghanistan was elected by:all the parties, the ulema, the inujahideen and the regional commanders. - PPI

THE NEWS INTERNATIONAN

\section{Sayyaf's party denies link with Mullah Rocketti}

\section{Bureau Report}

PESHAWAR, April 27: A spokes. man for Prof Abdul Rab Rasul Sayyd's Ittehad-i-Islami today denied the Ittehad's connection in any way with the former comman. der of Zabul province of Afghanistan, Mullah Abdul Salam Rocketti, who is wanted by the Pakistan authorities in various cases of kid napping Pakistani nationals and foreign citizens, including the Deputy Commissioner, Ziarat.

Prof Sayyaf's spokesman was conımenting on a newspaper report emanating from Quetta which said that the notorious gang leader belonged to the Ittehad-i-Islami Afganistan. He expressed surprise over the distribution of such a fab. ricated news with apparently malicious intentions by the official news agency of Pakistan. He said his party vehemently rejected hav. ing any ties with Mulla Rocketti and the Prof Sayyaf being a staunch friend of the l'akistani people could never recommend a wanted criminal like Rocketti for appointment as governor of the Zabul province. He further clarified that at no stage of Afghan Jehad Mulla Rocketti was associated with the Ittehad-i. Islami.

\section{DAWN}

28 APR 1994

\section{APR 1994}




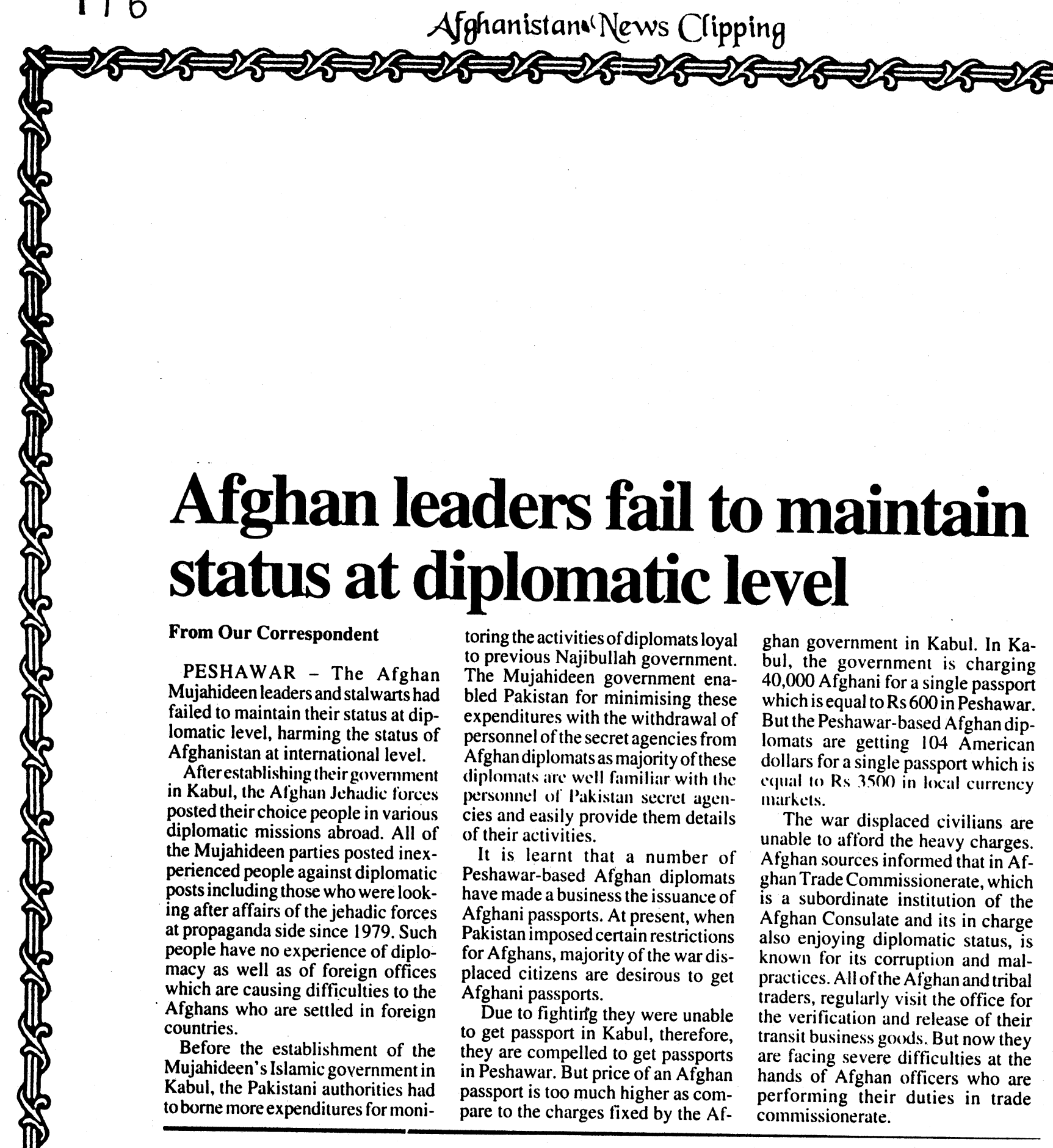

NATION

02 APR 1994 


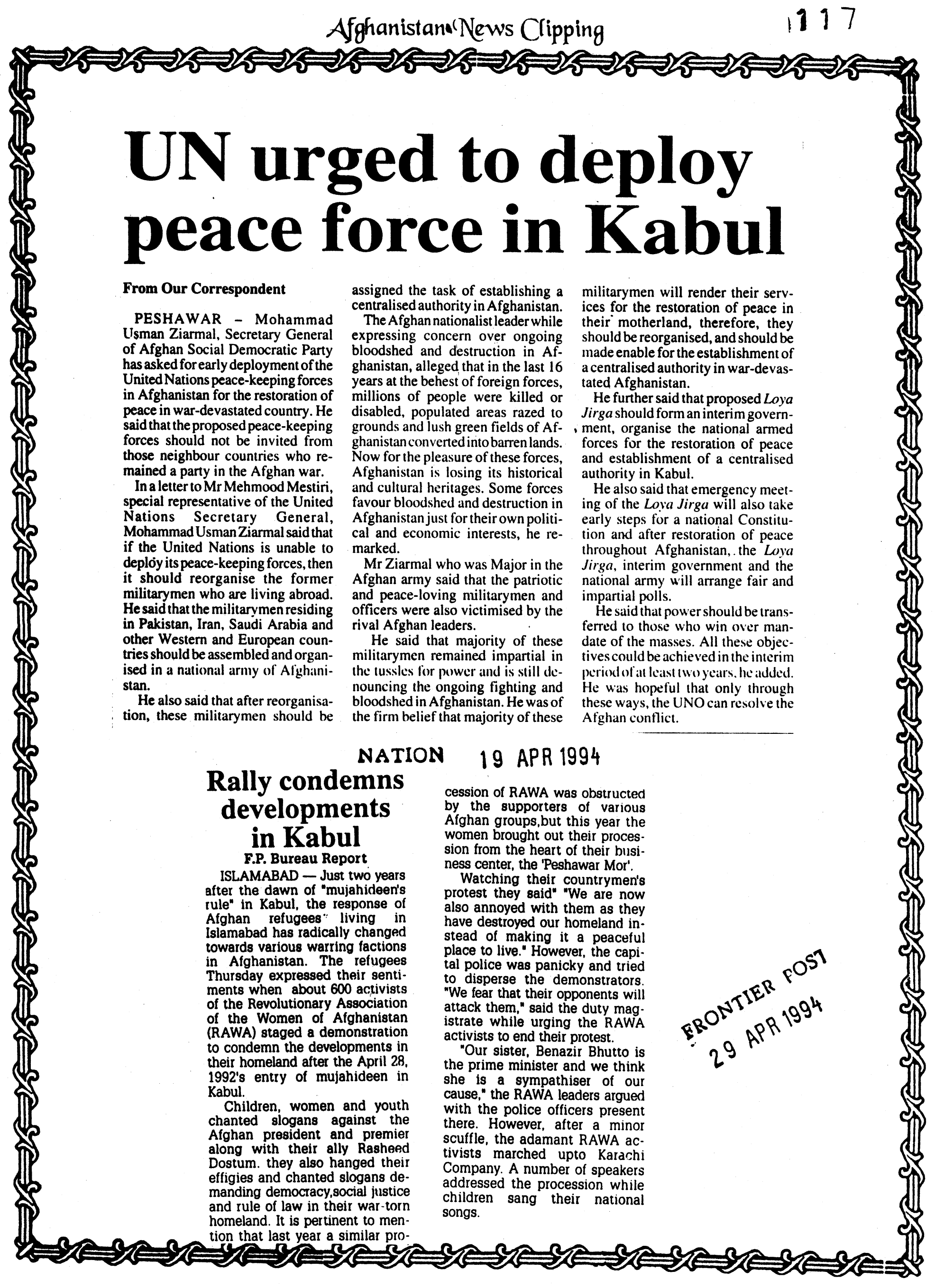




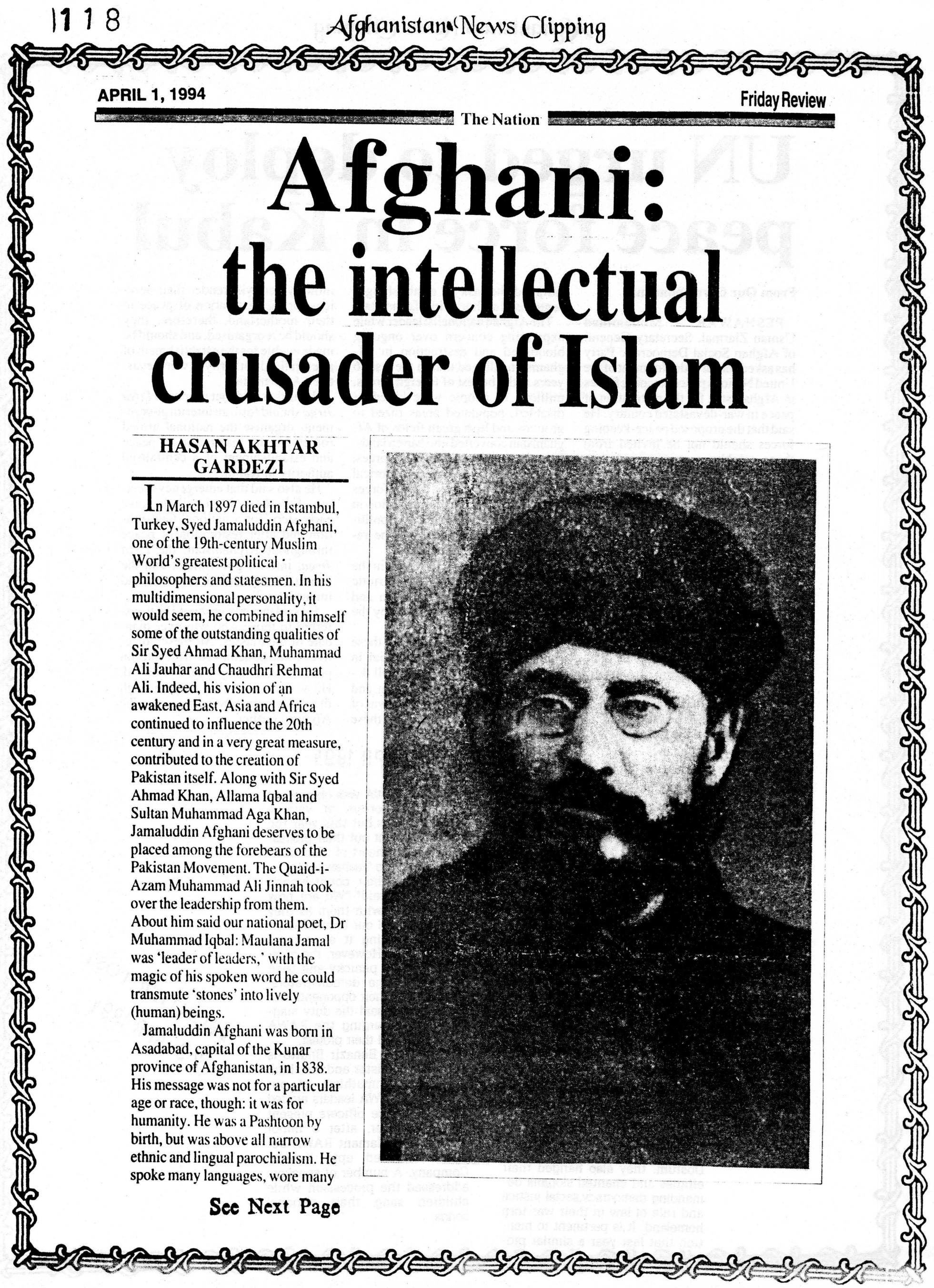


hats and lived in many countries. He was equally at home with the Afghans, Iranians, Turks, Arabs and the people of Central Asia and South Asian subcontinent.

It behoves Muslims all over the world, Pakistanis in particular, to remember him with feelings of deep love and gratitude. We should try to learn and benefit from his experiences.

When Jamaluddin Afghani was eight years old, his father, Syed Muhammad Safdar, fell into disfavour with the rulers in Kabul. He was ordered to abandon his hometown, Asadabad, and come and live in the capital as some sort of a hostage. In Kabul, Jamaluddin received all available knowledge and education. At the age of 18 , he was sent to India (of those days) to study mathematics. After a year in India, he left for pilgrimage to Makkah. The journey to Makkah took him about a year. On the way he travelled through many Islamic countries.

When he returned to Afghanistan, Amir Dost Muhammad Khan,

recognising the extraordinary abilities of Jamaluddin, appointed him as Adviser to himself. After the death of Amir Dost Muhammad Khan, his son, Sher Ali Khan, become the Amir.

During the reign of Sher Ali Khan, Syed Jamaluddin Afghani started the first newspaper in Afghanistan by the name of Shams-ul-Nahar. Copies of this newspaper were sent to many Islamic countries and made powerful impact there, says his biographer Professor Iftikhar

Hussain of the Peshawar University. In the later part of the 19th century, Afghanistan was full of intrigues and counter-intrigues spawned by the Russians in Central Asia and the British in India. The Great Game of which Kipling writes so eloquently in his novels was on. Jamaluddin decided to get out of Kabul and go to Egypt .... Thus began his remarkable career as a journalist, teacher, diplomat and statesman on a wider international spectrum.

From Cairo Jamaluddin went to Istanbul, where the Sultan of Turkey appointed him as an Adviser to the Ministry of Education. Many "religious leaders" of Turkey, however, did not agree with the progressive ideas of Afghani and he was compelled to go back to Egypt in 1871 .

In Egypt Jamaluddin set up a school at his residence: Among his students one was Muhammad Abduh, who later made a name for himself in the Arab world. People belonging to his group also started three newspapers: Misr (Egypt), Mahroosa (Fortified Area), and Miratul-Sharq (Mirror of the East). This happened at a time when the Suez Canal was gaining importance and the British and the French were vying with each other for the control of the waterway. Syed Jamaluddin Afghani wrote articles against Western imperialists.

In 1879 , Jamaluddin was forced to leave Egypt and go to India. Initially, he had wanted to settle down in Hyderabad. But his presence in a Muslim principality was not welcome to the British overlords. So, he went out to live in Calcutta.

In 1883, Jamaluddin went to England and France. In France he started a newspaper in the Arabic language by the name of Orw'atul Wasqa (Strong Rope). Muhammad Abduh wals its editor. The newspaper createu a stir: and its circulation was banned in India, Egypt and many Islamic countries which were under British domination. Printing presses in France refused to print the newspaper.

It is noteworthy that Syed Jamaluddin was very highly regarded in the intellectual circles of Paris. The great French philosopher, Monsieur Renan, called him "living" Ibne Sina and Ibne Rushd.

When the Mehdi Sudani rose in revolt against the British in Egypt, Jamaluddin went to London for consultations.

He went to Moscow and persuaded the Russian government to lift ban on the printing of the Holy Quran and other religious books.

For a time (1886 -

1887) Jamaluddin.

Afghani served as

Defence Ministry of

Iran under King

Nasiruddin. As

elsewhere, Jamaluddin

gathered around

himself a multitude of

young men who

wanted changes and modernisation in the

society and methods of

governance. The King

was persuaded that the

Syed was a dangerous

person. So, he left

Tehran and went over

to Moscow in 1887.

Here he started writing

political reviews in

Russian newspapers on countries like Afghanistan, Iran, Turkey and Great Britain.

From Russia Jamaluddin went to Germany and then to France. In Paris, he had a meeting with the visiting Persian King, Nasiruddin, who once again invited him to be his close friend and adviser. The Syed complied and went to Tehran.

According to Syed lftikhar Hussain, "Because of his prominence, the Prime Minister became jealous of him and poisoned the King's mind against him." Noticing a change in the King's attitude, Jamaluddin begged permission to go to the shrine of the saint, Shah Abdul Azim. He lived there for nine months. "His fame had spread throughout Iran, and people flocked to see him and to listen to his discourses. The king, fearing that a revolution might erupt, ordered his arrest and deportation." At the time of his arrest, he was very sick. All the same, he was tied on a horse's back and taken across the border to Basra (Iraq), which then was part of the Turkish Empire.

Going back to London, Syed Jamaluddin Afghani brought out a newspaper Ziaul Khaliqeen, which was published in two languages, Arabic and English. This paper was banned by the British Government at the request of the Iranian

Government.

Syed Jamaluddin was invited by Sultan Abdul Hamid to come and live in Turkey. He was given a huge house in Constantinople. Yet, says his biographer, "Syed Sahib was as political in Turkey as he ever was elsewhere.... The Sultan got scared of his presence and had him arrested." It was during his incarceration or house arrest in Turkey that Jamaluddin Afghani died of an incurable disease, deemed to be cancer, on 9 March 1897 at the age of 58. He was buried in the cemetery of Mashaikh. In 1944, after long and difficult correspondence between the governments of
Afghanistan and Turkey, the mortal remains of Syed Jamaluddin Afghani were repatriated. They arrived in Karachi in December 1944, and then carried to Peshawar by train. All along the route, Karachi-Lahore-Peshawar to Kabul, his remains were given enthusiastic welcome. A few miles outside the city of Kabul, people gathered in large numbers to pay homage to a great man who had finally come back to his homeland, from where he had started his mission for the unity and modernisation of the peoples of the Islamic world.

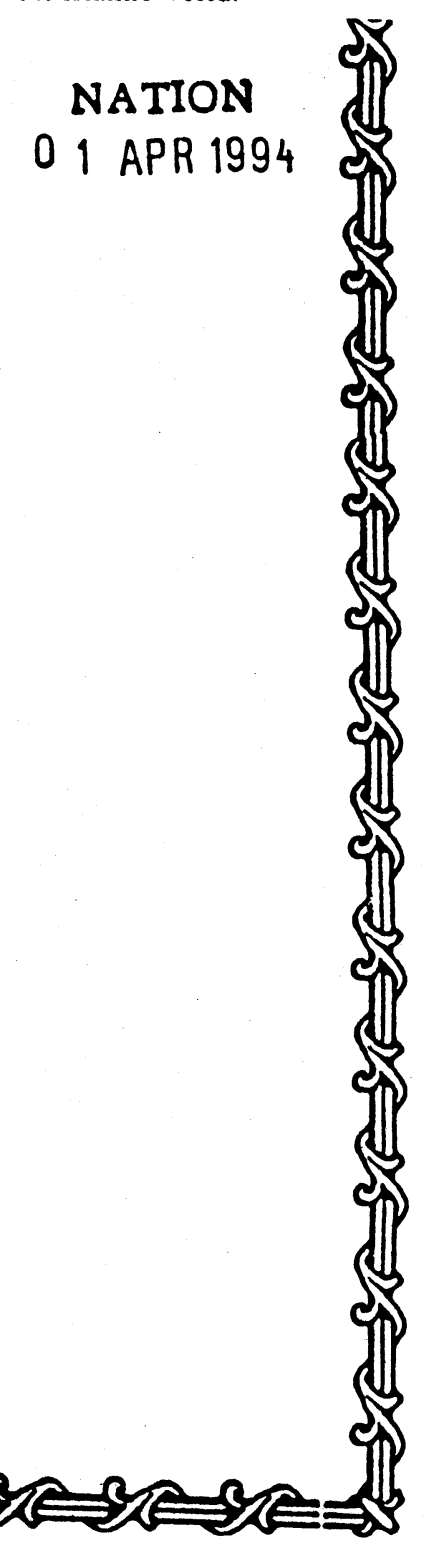




\section{Refugees rally demands Afghan rulers' resignations}

\section{Bureau Report}

PESHAWAR: Availing UN peace mission head Mahmood Mestiri's presence in Peshawar, peace-loving Afghans staged a big demonstration here Tuesday to demand resignation of President Rabbani and Prime Minister Hekmatyar and an end to foreign interference in Afghanistan.

It was probably the first time in Peshawar that Afghans poured out into the streets in such numbers to denounce the mujahideen parties and demand disbanding of the armed Afghan factions formed on foreign soil. The demonstration, organised by the Council for Understanding and National Unity of Afghanistan, began from Spin Jumaat mosque where Fateha was offered for those killed in the Afghan war and concluded at the UNHCR office. The Council, which groups together various nationalist, liberal and pro-Zahir Shah groups and indivichuals, had made arrangements to bring th : protestors from refugee f camps and , srtain schools, including
Siddiq Akbar School.

Mahmood Mestiri, accompanied by UN Secretary General's special envoy on Afghanistan Sotorious Misouris and other members of his delegation, earlier met about 250 Afghan women who had gathered in a house in University Town, Peshawar. The women, mostly educated and urbanite, presented him a memorandum that demanded representation for women in the Loya Jirga and called upon the UN to take notice of the violation of women's rights in Afghanistan. It appealed women's organizations worldwide to offer support to alleviate the sufferings of Afghanistan's female population.

Later at the men's demonstration, the 65-year old Mestiri boldly climbed a vehicle fitted with loudspeakers when invited by the organisers and made a speech to the demonstrators outside the UNHCR offices. Speaking through an interpreter, he promised to strive for restoration of peace in Afghanistan in keeping with the aspirations of the Afghan people. He said the peace march and his meetings with various Afghan delegations and individuals had convinced him that most Afghans were fed up with war and were ready to back peace initiatives.

Amidst slogans, the organisers presented a memorandum to Mestiri in which leaders of the warring Afghan factions were asked to respond positively to the UN special mission's appeal for an immediate and permanent ceasefire. Resignation of the Afghan leaders holding official posts was also demanded so that power could be transferred to a broad-based interim govt elected by a UN-sponosred Loya Jirga. Foreign interference in Afghanistan was condemned and mediation by regional powers was opposed as it was bound to prolong the agonies of the Afghan people. A demand for disbanding armed Afghan factions founded on foreign soil was also made and surrendering of heavy and light weapons in their possession to a neutral commission was proposed. 


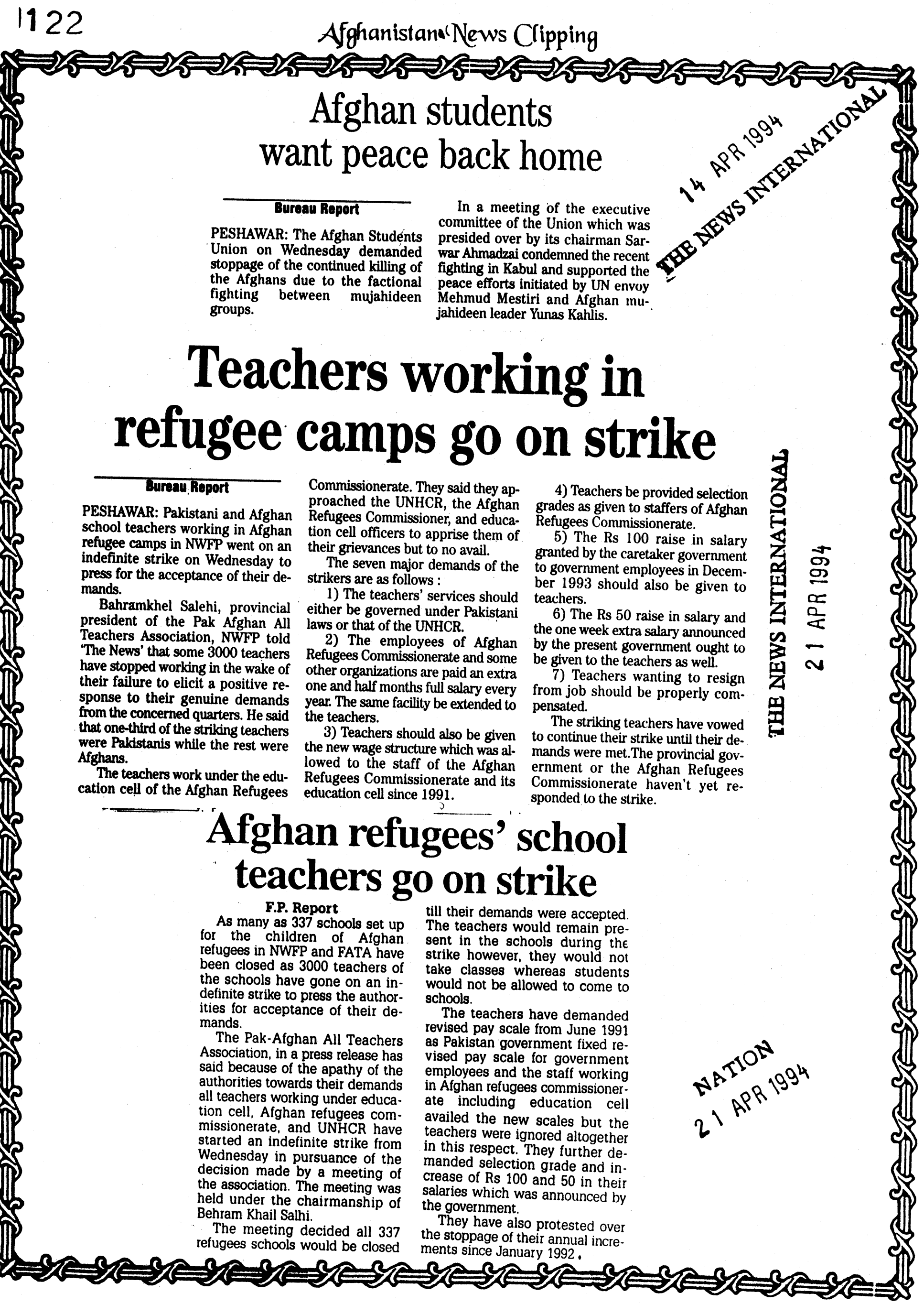




\section{Afghan rally wants Zahir Shah to return}

QUETTA (Reuter) - A special UN mission seeking peace in Afghanistan was greeted here on Saturday by a noisy demonstration by several hundred supporters of former Afghan king Zahir Shah.

Truckloads of Afghans waving Afghanistan's old black, red and green royal national flag greeted the mission leader, former Tunisian foreign minister Mahmoud Mestiri, as he arrived in Quetta.

They shouted slogans in support of Zahir Shah, who is living in exile in Rome since he was toppled in a 1973 coup, and demand. ed he brought back to play a role in the Afghan political process.

They called for the convening of a traditional Loya Jirga (grand council) to decide the political future of their war-ravaged country.

"We want Zahir Shah". "We want Loya Jirga", "We don't want foreign interference", they shouted.

Mestiri is hearing the views of Afghans on how the UN can help to end factional fighting that has killed more than 11,000 people in the two years since the mujahideen took power from the former Soviet-backed government after 14 years of civil war.

Mestiri heard more than $100 \mathrm{el}-$ ders, religious leaders and people from southern Afghanistan at a meeting in a Quetta hotel.

Many called for the resignation of both Afghan President Burhanuddin Rabbani and his arch-foe Prime Minister Gulbuddin Hekmatyar, who are battling for supremacy in Kabul, and for the formation of an interim government of neutral Afghans.

They also demanded the UN play a greater role in the Afghan political process.

Heated disagreement erupted

\section{ERONTIER POST 24 APR 1994}

\section{Najib's portrait ion vehicles}

\section{From Gul Naeem}

PESHAWAR - The frustration, prevailing among common Afghans came out with explosion against the ongoing bloody power tussle in Afghanistan when they publicly tendered support to the former rulers of that war-shattered country including Dr. Najibullah.

Since the outbreak of war in Afghanistan, the Afghanistan, living in Peshawar for the first time displayed the portrait of $\mathrm{Dr}$ Najibullah, at back of their vehicles. between speakeis who called for a Loya Jirga, traditionally attend. ed by tribal leaders, and those who wanted an Islamic shoora.

However, the majority of men at the meeting joined to shout down one man who suggested that because women made up half the Afghan population, they should have equal participation in national affairs.

"It is good that we can speak with different opinions without shooting at each other," Mestiri told the meeting.

"I have heard your arguments for a ceasefire, for collection of weapons and against foreign in. terference. We are for you on these three matters," he said.

Mestiri is due to leave for the southern Afghan town of Kandahar on Sunday (today) in his fourth trip into Afghanistan since he began his mission late last month.

\section{NATION}

14 APR 1994 


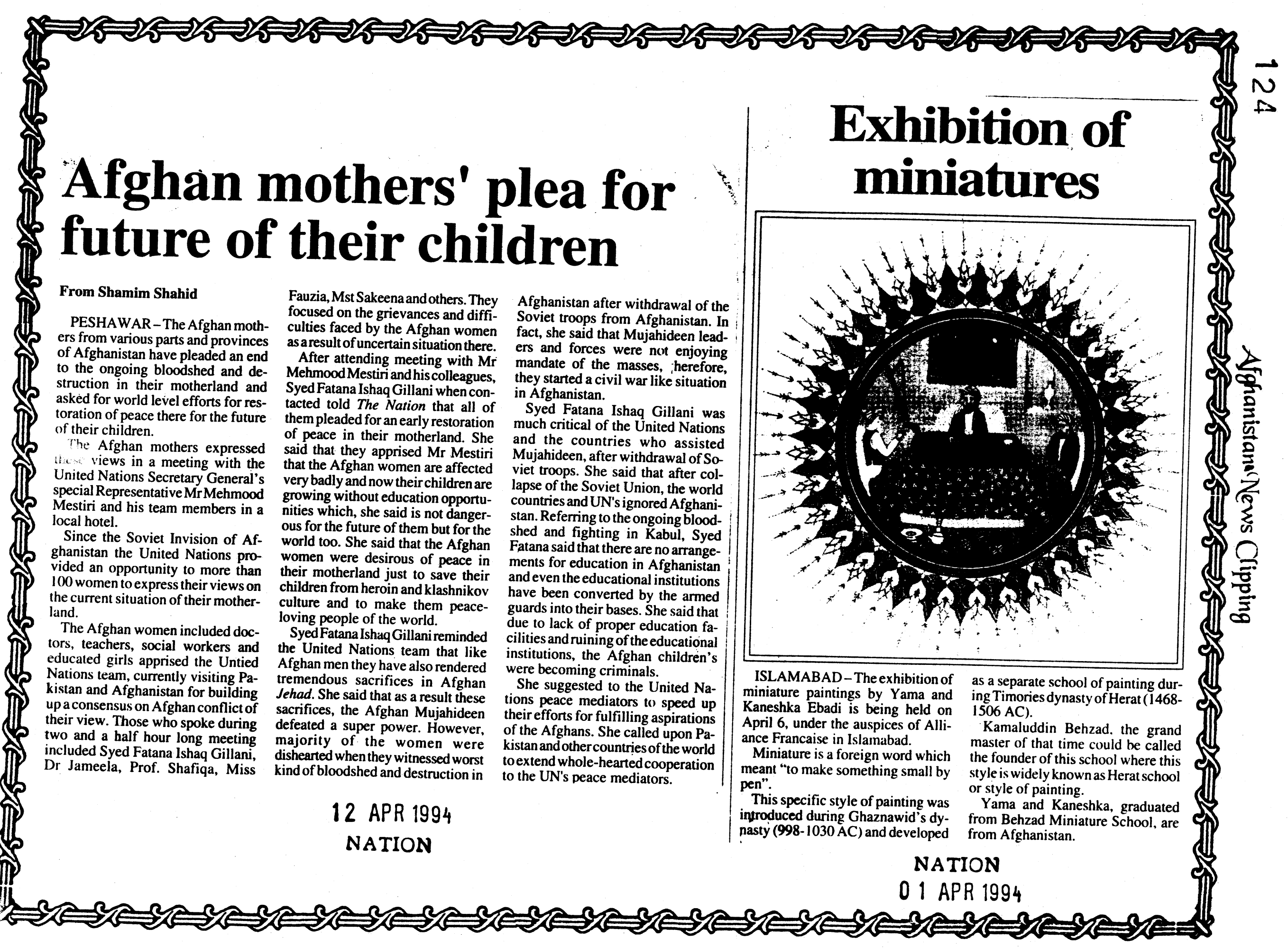




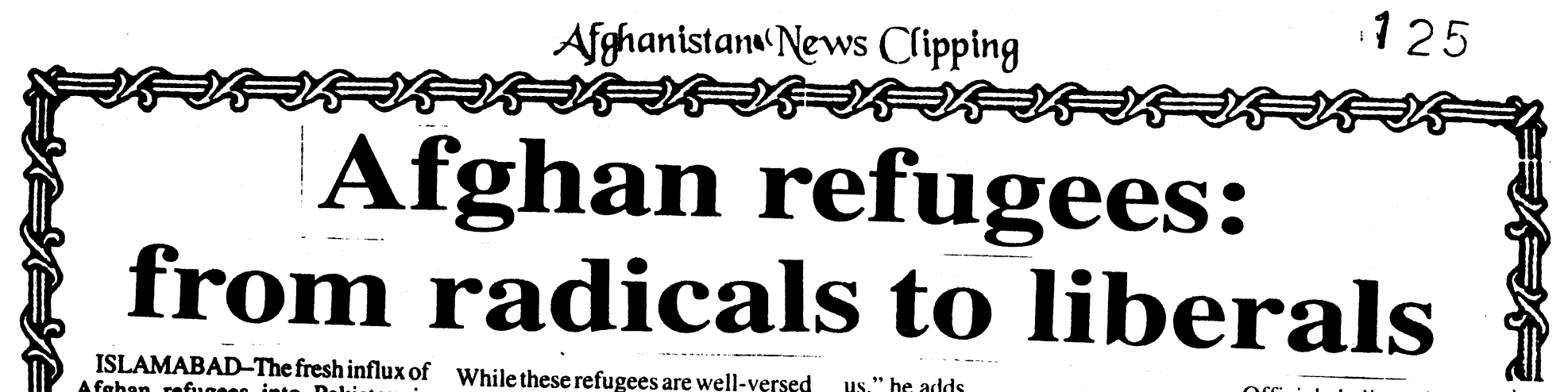

ISLAMABAD-The fresh influx of Afghan refugees into Pakistan is bringing a qualitatively different Afghan lot compared to those who came during the last 14 years.

The Afghans crossing over to $\mathrm{Pa}$ kistan today are a Westernised Persian-speaking lot. A departure from the traditional Pushtoons with long beards and turbans, they are bettereducated and far more liberal than the rural Afghans.

A large number of refugees coming from urban Afghanistan are professionals. Many are Moscow qualified doctors and engineers, almost an equal number of them women. Among them are UK and Australia trained engineers and doctors, exarmy officials and executives working in major international organisations such as the World Bank.

According to one estimate over 60,000 Kabulites have made their way to Pakistan in the last six months alone. "We expect more people in the next few months," a highly placed official in the Interior Ministry told this correspondent in a recent interview.

"These are the people who had affiliations with the Najib government and had to leave Kabul because of constant threat from the Afghan Mujahideen," these sources maintain. "If they don't quit Kabul, they die."

"Financially better off, they are soft and generally peace-loving people," says a Foreign office source, adding that "the well-to-do ones are refined people and prefer going to Islamabad and Karachi."

"We are witnessing a new phenomenon now. Fourteen years ago when the war started in Afghanistan with the Soviet intervention there, Pakistan saw a massive inflow of the Afghan refugees largely from the rural areas but since the Afghan Mujahideen captured Kabul it is mostly the urbanites who are crossing over to Pakistan now," an Interior Ministry official notes.

Not surprisingly, at present most of these professionals feel frustrated in Pakistan. They have no job openings as they face language handicap.

While these refugees are well-versed in Persian, Pushto and Russian, only a few can speak proper English.

But officials believe their frustration is only a matter of time as they are quick at picking up languages. "Even before we know they" will be holding white-collared jobs in the major cities," comments a government official involved with the rehabilitation of the refugees in Peshawar.

Families of Afghans from the urban-based areas have been divided and therefore they have dual lodging places, both in $\mathrm{Pa}$ -

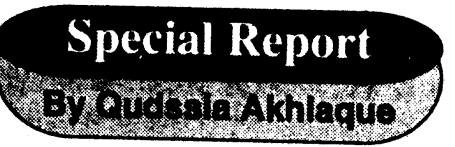

," he adds.

There is no possible way that you can completely stop their entry into Pakistan. Even if you seal the borders. There are a lot of other routes through which they can come in, admits another senior government official.

"Any attempt to stop them can backfire," warns an official of Pakistan mission in Kabul currently in Islamabad, referring to the hijacking of a Peshawer School Bus by three

kistan and in Afghanistan. Forced out of their homeland because of a situational factor, there is general discontentment among them and they are not happy to be in Pakistan.

"Don't look at them in the classic way of aliens, they are proud people," says a senior government officer dealing with the Afghan refugee population. "The Kabulites are open people and not too comfortable with
Afghans in February.

Agreeing that the process of restricting the Afghans should start now, the official insists that it has to be gradual process otherwise it would create problems.

Concerned Interior Ministry officials say that the government's policy on the Afghan refugee question is fluid and that it is still unclear on how to tackle the issue. They hold that there is an absence of a clear-cut political stand on the issue.

\section{Old refugees create problems for newly arrived Afghans}

\section{Bureau Report}

PESHAWAR: The newly-arrived Afghan refugees have complained that they are facing hardships in the process of registration of their names as refugees to secure the ration cards.

The refugees alleged that the issue has been brought to the notice of the officials of the United Nations High Commission for Refugees (UNHCR) and the Afghan Refugees Commis. sionarate. However, no action has yet been taken.

The Afghans, fleeing the latest $\propto$ bout of fighting which erupted in $\Omega$ Kabul on January 1, said they deserted the Nasir Bagh refugee camp near Peshawar due to some security problems.

They said the ration cards were being denied to them because and they were compelled to leave the camp. The refugees put the blame on the old refugees who are settled at the camp for quite a while now and said they were creating severe problems ior them.
Officials believe that for sècurity reasons Government of Pakistan must restrict the movement of refugees and not allow it in Islamabad and Punjab. "USSR has ended but not Russsia, and who knows there may be KHAD agents amongst them," a concerned official points out.

Meanwhile, the Pakistani officials are critical of UNHCR for not extending its umbrella to the new entrants. "Once the United States' strategic interest in the region diminished so did the UNHCR's support for the refugees," observed an agitated official.

"When Pakistan sealed its borders, UNHCR was clamouring away and raised such a hue and cry over it but UNHCR itself is now not providing the help that it should be to the new Afghan refugees," says another official. At present aid on regular basis for Afghan refugees comes in only from UNHCR and the World Food Programme, while there is sporadic aid from Saudi Arabia and China.

While there are no statistics to indicate how many Afghans cross over

to Pakistan every day, a daily average of three to four refugees reports in Islamabad alone. And this despite the fact that there is not even a single refugee registered in the Federal capital.

"An average three to four Afghans, men and women, seeking financial assistance visit the Afghan Commissionerate and the UNHCR offices in Islamabad,"Commissionerate sourc. $\therefore$ lold The Nation. This pattern hes been going on for the last three nunths. "There are days-whenias 'lany as 50 have come in asking $60 \mathrm{r}$ elp," says a Commisionerate offi-

There are three figures pertaining to the present Afghan refugee population in Pakistan. While the Government of Pakistan maintain 1.4 to 1.6 million, UNHCR insist on 1.1 to 1.2 million. But the actual number is estimated to be around 1.8 million including the inflow of unregistered refugees.As more Afghans continue to cross over to Pakistan, they are eating up the country's scarce resources.

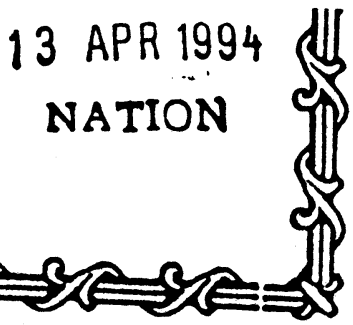




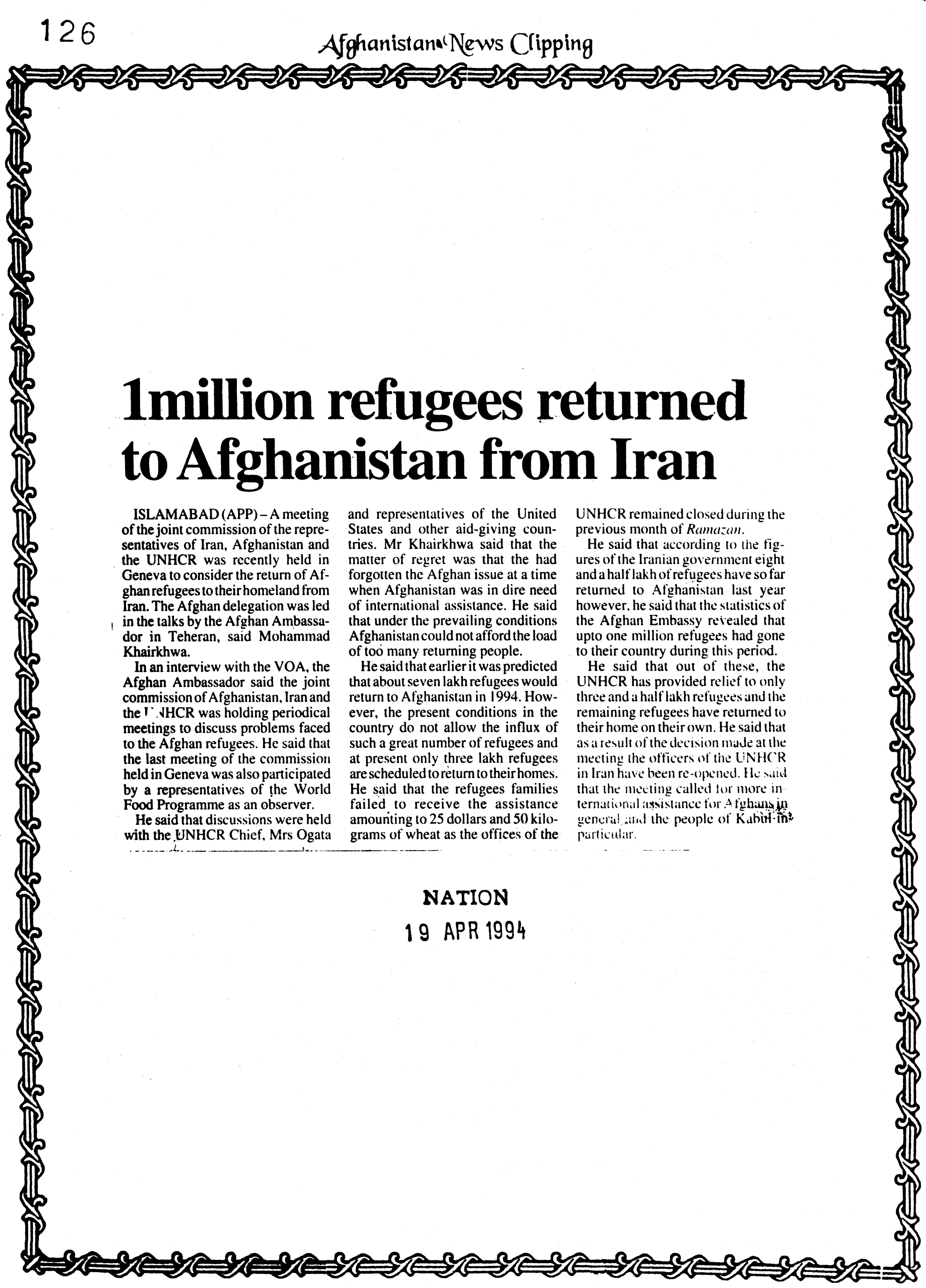




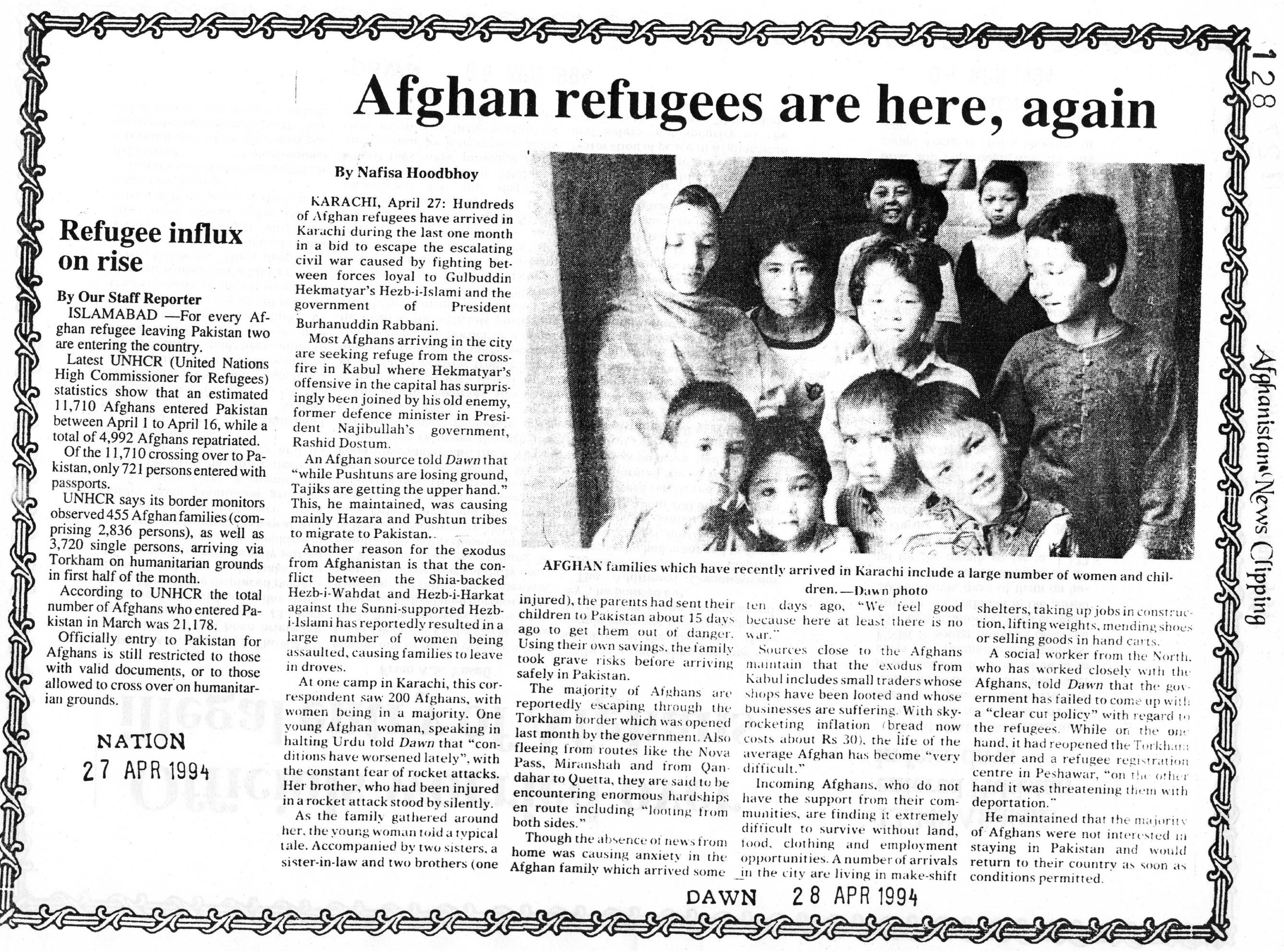




\section{$0.4 \mathrm{~m}$ Afghan DPs still in \\ Balochistan} refugees living in Balochistan

QUETTA (PPI) - There are nearly four lakh Afghan refugees living in various tented villages in
Balochistan.

This was stated by Farooq Jogezai, commissioner Afghan refugees, Balochistan, here
Thursday.

He said an equal number of Afghan refugees got themselves deregistered last year following the end of communist rule and establishment of mujahideen's Islamic government in Afghanistan after 14-year war. He said presently these refugees were waiting for return of peace in Afghanistan. He said no sooner these conditions improved, Afghan refugees living in tented villages along border areas of Balochistan would repatriate to their country.

Referring return of Afghan refugees to Afghanistan from Iran under the auspices of United Nations High Commission for Refugees (UNHCR) Jogezai said so far UNHCR. has not initiated any of its programme. The programme is suspended for the last few months due to some misunderstanding between UNHCR and Iranian authorities

QUETTA, April 7: There are nearly 0.4 million Afghan refugees living in tented villages in Balochis. tan.

This was stated by Faroog Jogezai, Commissioner, Afghan Refugees Organistion (ARO), Balochistan, while talking to PPI here on Thursday.

He said that an equal number of refugees had got themselves deregistered last year following an end to communist rule and establish. ment of Mujahideens' government in Afghanistan after a 14-year Jihad. He said the refugees were waiting for return of peace to Afghanistan. Whenever the situation-improvided, the refugees would return to their country, he added.

Referring to return of refugees to Afghanistan from Iran, under the auspices of United Nations High Commission for Refugees, $\mathrm{Mr}$ Jogezai said that so far, UNHCR had not initiated any fresh prog. ramme. A programme for the repat. riation of refugees from Iran to Afghanistan, via Balochistan, was suspended last year due to some misunderstanding. between UNHCR and Tehran authorities, he said. There were about $85,00()$ refugees living in Iran, who were scheduled to be repatriated in September and October last, he added. -PPI

\section{Afghan refugee population almost static since 1992}

\section{By Qudssia Akhlaque}

ISLAMABAD - The Afghan refugee population in Pakistan has remained more or less the same since December 1992, comparative figures show.

Official figures suggest that after reaching its peak in September 1990 , the number of Afghan refugees residing in Pakistan settled at around 1.7 million by end of 1992 . And it has remained almost static ever since.

At its highest level the Afghan population was recorded at $3.29 \mathrm{mil}$ lion in September 1990. The current Afghan refugee population is estimated between 1.6 and 1.8 million, half of the peak figure.

While the official figure of the Afghan refugee population has re- mained unchanged between December 31, 1992 and now, it does not mean that Afghans have ceased to cross borders.

Interior Ministry officials say that an estimated 60,000 Afghans, crossed over to Pakistan in the last six months, but about an equal number also left the country for their homes.

The outgoing refugees, they maintain, are mainly from rural Afghanistan, while the incoming are largely urbanites.

Official figures present an interesting pattern of the Afghan refugee inflow in Pakistan in the first 11 years of the Afghan war. During this period, from December 1979 to September 1990, the tide of the refugee population in the country continued to rise.
The number started to fall just ahead of the Najib government's fall in April 1992, and a sharp decline was registered in the eight months that followed the fall.

The total number of Afghan refugees on February 1991 stood at 3.24 million, which dropped to almost a half of that ( 1.7 million) by December 1992.

At present Pakistan houses a little over 1.6 million registered Afghan refugees, and there are another estimated 200,000 Afghans who are not registered with the Interior Ministry but continue to reside here.

The registered 1.6 million Afghans, totaling over 235,000 families, have been accommodated at 318 refugee camps throughout the country.

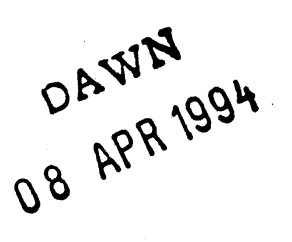




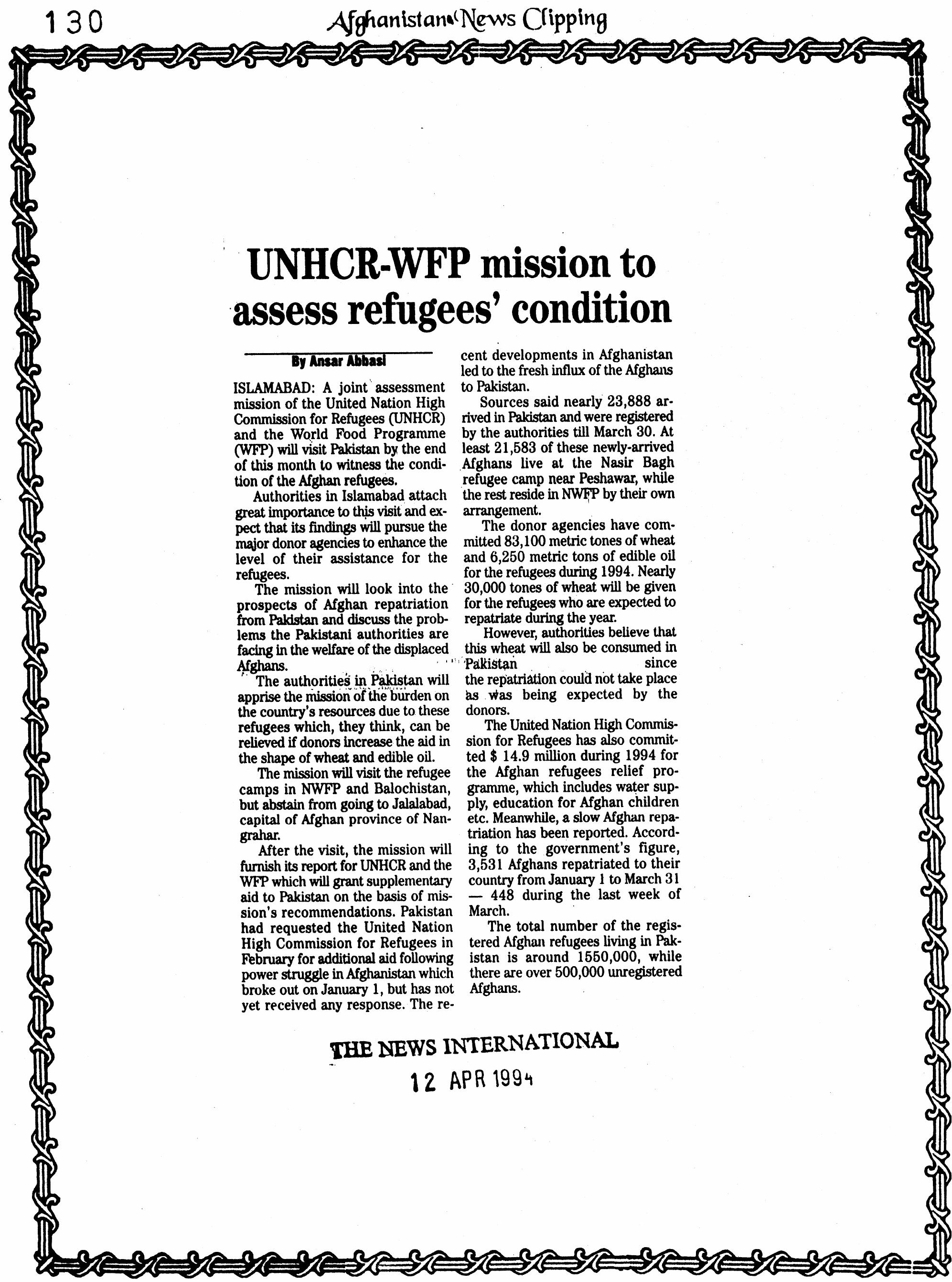


ISLAMABAD - Despite a clearcut Government of Pakistan policy to control spill over of Afghan refugees in the Federal Capital, refugee population here continues to be on the rise.

While there is not even a single Afghan refugee formally registered in Islamabad, over 30,000 Afghans are estimated to have moved into the capital city in the last six months alone.

Officials in the Interior Ministry nelieve that at least half of the refugees who have moved to Pakistan in the past six months are now residing in Islamabad. According to one estimate over 60,000 crossed over to Pakistan in the last six months.

As a matter of rule new Afghan refugees coming to Pakistan are not supposed to go beyond Attock, the Punjabi border town next to the NWFP. They are required to get themselves registered at Commissionerate for refugees in Peshawar or at the Commissionerate office in Quetta.

To discourage the Afghans from coming to and settling in Islamabad, the government has apparently also instructed the United Nation's High Commission for Refugees (UNHCR) not to provide any financial assistance to the new refugee population through its offices here.

But even this has not stopped the inflow of refugees who continue to pour in the Federal Capital.

\section{NATION}

\section{APR 1994}

These refugees, mostly Kabulites, are literate and well-to-do compared to those who fled to Pakistan in the early years of the Afghan war. Their resources, however, are limited. Af-

\section{Special Report}

$$
\text { B! Qudssia Mkilaryuc }
$$

ter exhausting the little finances they have, most turn to the UNHCR office here for assistance.

At the palatial UNHCR office on the Margalla Road the refugees are greeted by a blue notice board put on the wall outside. It says: "Notice To All Afghan Refugees. This office does not provide financial assistance

or resettlement services to Afghan refugees."

Those who are desperate for help, ignore this notice. They plead their case with the man at the main gate who invariably directs them to the Chief Commissionerate for Afghan Refugees (CCAR) here. He hands them small chits which have the CCAR address printed on them.

From the CCAR refugees are again turned away without help since it is only a policy-making office.

Officials at the CCAR maintain that they have categorically conveyed it to the UNHCR several times that they are not there to assist refugees. Despite repeated messages, these officials say, the UNHCR continues

to "misdirect" the refugees.

When contacted the UNHCR spokesman here told this correspondent that the office in Islamabad did not give financial or material assistance. This, he said, was in compliance with the Pakistan Government's policy. However, he added, that the Commision helped the refugees in other ways.

"We have a Social Service Section that attends to their security needs and also provides medical and legal aid to them," the spokesman said.

Meanwhile, an average three to four Afghans continue to show up at the CCAR in Islamabad.

"We want help, protection, and assistance," is usually what they have to say. "There are days when ever a couple dozen turn up," notes an of $i$ cial. "The most striking aspect abcut them is that almost all are sophisiticated urbanites, men and women, holding professional degrees," he adds.

These Afghans are concentratedin the rather thickly populated $\mathbf{G}$ and I sectors, where accommodation is available at relatively lower renis. Numerous apartments and flats in $\mathbf{G}$ 8 Markaz, G-9 and G-10 have beén taken by the Afghan urbanites, mapy of whom share them with their resatives and friends. Most new entrants have also rented out portions in sectors I-8. I-9 and I-10.

In fact many real estate dealersin Islamabad attribute the current level of rents in these areas to the large presence of Afghans. "There has been a growing demand for flats and portions in the $G$ and I sectors by the Afghans specially in the last six months," says a property dealer in G8 Markaz. Only recently the Federal Interior Minister also noted at a televised interview by journalists that house rents had gone up because of the Afghan refugees, which he be lieved was a good sign.

Like most parts of the G-9 and G10 Markazes, these refugees virtually throng the three weekly bazaars-Mangal, Itwaar and Jumain G-8 Sector. It is there that one actually realises what a large number of Afghans dwell in the capital city. Buyers as well as sellers, they dominate the scene. 

Was Pakistan legally bound as a member of the internathorial community
to offer refuge, temporary or permanent, to the Afghan migrants and not to
stop, reject and repel them, right at the borders? asks AKMMD FAROOQ

17 he Soviet invasion of Afghanistan in December 1979 forced hundreds of thousands of Afghans to migrate to some place where they could uphold their religious beliefs and socio-cultural traditions without any fear of physical and mental torture and persecution. Most of these forced migrants decided to move to Pakistan, a developing state with a meagre economy and hardly adequate resources to support it owt rapidly growing population.

The government and people of Pakisţan had been welcoming migrants from Afghanistan who had started coming in small numbers ever since the overthrow of King Zahir Shah by Muhammad Daud in 1973, but they were far from prepared, financially, materially or mentally, to receive the great influx of refugees caused by, the Soviet invasion. Playing host to this large Afghan population, which numbered 3.5 million by 1985 , not only entailed an over-stretching of the already fragile economy and limited resources, but also involved the risk of invoking direct Soviet aggression against Pakistan. It was a difficult decision and the quantum of problems involved could have deterred many affluent and developed societies from allowing entry to this uprooted mass of people. But Pakistan took an unwavering stand and opened its borders to the teeming Afghan refugees.

Pakistan's decision was guided by humanitarian considerations, socio-cultural and religious affinities between the two pepples, as well as some political, diplomatic and strategic interests at the natiopal, regional and international levels. Bupt.was Pakistan legally bound as a member of the international community to offer refuge, temporary or permanent, to the Afghan migrants and not to stop, reject and repel them, right at the borders? Did international law bind Pakistan to observe the principle of NonRefoulement?

The principle of non-refoulement says: "The'states shall not refuse admission to a refugee, i.e., they shall grant him at least temporary asylum - if non-admission is tantamount to surrender to the country of persecution."

The applicability of the principle of non-refoulement to Pakistan and Pakistan's legal obligations in this respect can be studied under the following titles:-
A. Obligations under International/Regional Conventions.

B. Obligations under International Law.

C. Obligations under national law.

The one international convention which obliges the states to observe the principle of non-refoulement and not to return or expel the refugees is the 1951 UN Convention relating to the status of refugees. Its Article 33 provides that "no contracting state shall expel or return (refouler) a refugee in any manner whatsoever to the frontiers of territories where his life or freedom would be threatened on account of his race, religion, nationalities, membership of a particular social group or political opinion."

However, Pakistan is neither a signatory to the 1951 Convention nor its protocol of 1967 which expanded its scope. Thus not being a 'contracting state', $\mathrm{Pa}$ kistan is not under any legal obligation to observe the rules and principles enunciated by the convention or its protocol.

Secondly, in strict legal terms, Afghan migrants to Pakistan otherwise do not qualify as 'refugees' according to the 1951 Convention's definition of the term 'refugee' even after its exclusion of the words, "As a result of events occurring before January 1951," by the 1967 protocol.

According to the 1951 Convention and its protocol, a refugee is a person who-

"Owing to a well-founded fear of being persecuted for reasons of race, religion, nationality, membership of a particular social group or political opinion is outside the country of his nationality and is unable, or owing to such fear, is unwilling to avail himself of the protection of that country, or who, not having a nationality and being outside the country of his former habitual residence - is unable or owing to such fear is unwilling to return to it."

This definition refers to the person or persons undergoing or fearing to undergo persecution and does not extend its scope to victims of generalised violence or internal turmoil, which is exactly the case with the Afghans, who fall into the category of humanitarian refugees rather than political and social refugees.

Secondly, in a situation like the Afghan influx to Pakistan, there simply is no time and necessary organisational setup to do the individualised screening commonly necessary to apply the Con- vention's definition.

Thus Pakistan had no obligations under the 1951 Convention or 67 Protocol, as, first, it is not one of the 'contracting' states and, secondly, the Convention's definition of 'refugee' in the context of Afghans, can be argued about.

As for any regional agreements, uch as the famous OAU Refugee Convention of 1969 or the Cartagena Conventic 1 of 1984, the principles laid down by these conventions do have international recognition and scope but their bindirig effect does not go beyond their respective regions and the contracting states and both - where Pakistan stands out.

Pakistan, therefore, had no contractual obligations under any international/regional agreement or convention to accept the Afghan refugees.

Pakistan is not a signatory to any of the international or regional conventions or agreements on refugee status, but there are some who believe that the principle of non-refoulement has achieved mandatory status as part of general international law and it thus binds all states, whether or not they are signatories to the refugee treaties, and also that "evidence relating to the meaning and scope of nonrefoulement in its conventional siuise amply supports the conclusion that todr. $h$ the principle forms part of general international law and there is substantial, if not conclusive authority that the principle is binding on all states, independent of specific assent."

By joining the UN, Pakistan, in a way, is part of the international community and has formally agreed to abide by the general laws and rules regulating international interaction and code of conduct. Thus it is obliged to uphold the principle of non-refoulement, if it is in practice as a customary international law or has been accepted as a general law by the UN. But there is a big IF here, which raises two questions.

A. Has the principle of non-refoulement been in practice in a tyy as to be recognised as a customary lf hernational law?

B. Has Non-Refoulement been accepted by the UN as a principle of general inter: national law, and is it mandatory upon member states to observe it?

(to be concluded) Next Month 


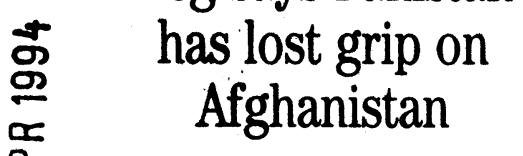

'From our correspondent

QUETTA: Former Chief of the Army Staff General (Retired) Mirza Aslam Beg on Sunday admitted that Pakistan had lost its grip on Afghanistan.

He was talking to a group of newsmen here on Sunday afternoon.

When asked about Pakistan's grip on Afghanistan, the retired general said that unfortunately there had been no coordinated policy towards Afghanistan for the last two to three years. "Some powers are anxious to seclude Pakistan from Afghanistan and they have succeeded in their efforts, "he said.

When asked to name those powers or the agencies, the former COAS said that RAW, KGB and CIA had their interests and the kidnapping of a school bus from Peshawar and the attack on Pakistan Embassy in Kabul were a part of incrigues to pitch Pakistan and Afghanistan against each other. "As a result of these intrigues, we have lost our grip on Afghanistan," he said.

The retired general opposed a national army, a proposal which would reduce the strength of the regular army. He said it was a wrong impression that the national army would be an economical option. "In a situation where our enemy India has a three-times larger army, fivetimes larger air force and ten-times larger navy, Pakistan should not even think

reducing the regular army as it will be tantamount to compromising the national defence," the general declared.

The former COAS said that Israel could afford to maintain a national army because it was fully patronised by the United States. "Our enemies who are always ready to launch an offensive against Pakistan will take on the country before we mobilise the national army, ${ }^{n}$ he said.

To another question, Beg said that the nuclear programme of the country was an effective deterrent for defence and was never capped till at least 1991.
05 APR 1994

NATION

Kabul again approached: kidnapped people

ISLAMABAD, April 4: The Government has once again taken up with the Afghanistan government the question of safe and uncondi. tional release of Chinese engineers and Pakistan officials kidnapped by an Afghan national, Mullah Salam.

Afghan ambassador Sardar Mohammad Roshan was sum. moned to the Foreign Office on Monday morning and handed over a diplomatic note urging the Afghan government to intercede urgently for arranging the safe release of the Chinese engineers and the Pakistan officials who are held by Mullah Salam on Afghan territory, it was officially learnt.

Mullah Salam, known as 'Rocketi' has been involved in several criminal activities. Border violations by him include firing from across the border with multi-barrelled rocket launchers, mortars and automatic weapons on Frontier Corps posts in Balochistan at Qamardin Karez, Badini and Kashatu. Apart from heavy damage to property, these attacks have resulted in a number of casualties.

The government of Pakistan has been trying its best to secure the safe and unconditional release of the kidnapped people and resolve the matter amicably but these efforts have not yielded a positive outcome so far.-APP

\section{Plan to cut cost of wheat quota for Afghanistan}

By Our Staff Reporter

ISI AMABAD - - Pathistim @orcm. ment is plannin: 10 . yuota for wheal supplics io Southern Afghanistan to control smugeling.

This and severalsother preposals were reviewed here on Sunday at a meeting between the Federal Commerce Minister. senior officials of the Ministry of Interior. Inter Services Intelligence (ISI) and Commissioneralc of Afghan Refugees besides the LIN officials.

Federal Coimmerce Minister $C h$ Ahmed Mukhtar told journalists al. ter the meeting. Pakistan "as re sponsible for meeting Southern At ghanistan s demand of 2 milliontom of wheat every year. Howerer. he said the country had provided onls $2(0) .(0) 0$ tons in the previous yeill while the rest was smuggled illegally.

The Minister said. Pakistan gor ernment provided wheat supply quo tas to traders in the tribal areas who sold them at lucratice premiums 11 suppliers in Peshaw ar and other part of NWFP.

As a result of this. the Minister explained. a bag of wheat which should be supplied for Rs 110 (1) R 150. cost as much as Rs $30(0)$ (1) con sumers in Southern Afghanistan.

The Minister did not answer a yues tion about the impact on the domestic wheat stocks of such massic supplies to Afghanistan.

NATION

05 APR 1994 


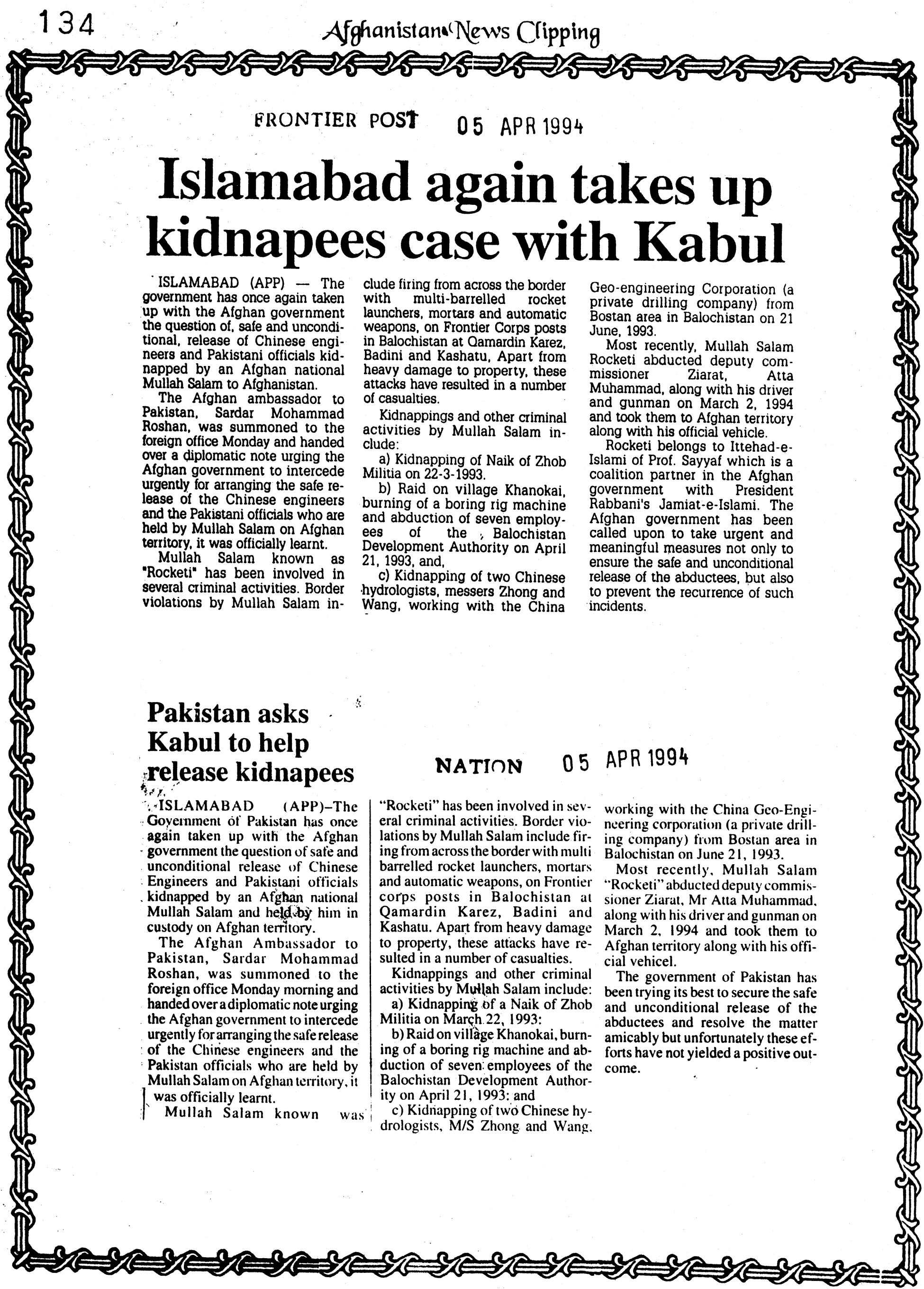




\section{By Marlana Baabar}

ISLAMABAD: The Government of Pakistan on Monday sent a strong message to President Rabbani that his government should exert pressure on Mullah Salam, who is involved in several criminal activities in Pakistan.

Pakistan has demanded the safe and unconditional release of Pakistani officials and Chinese engineers held in Afghanistan by Mullah Salam, or as he is popularly known, Mullah Rocketi.

The message was conveyed to the Afghan Ambassador, Sardar Mohammad Roshan, who was summoned to the Foreign Office on Monday by the Director General of the Afghan Desk, Kaxi Humayun. Besides the Pakistan officials and the Chinese engineers, two Pakistani students are also held inside Afghanistan by Commander Ahmed Shah Masood.

Officials say President Rabbani was told "in à very forceful manner" during a meeting with Prime Minister Benazir Bhutto last year that "his government had to exert pressure on
Mullah Salam to release the detentes". Rabbani is said to have given a firm commitment that he would "try his utmost". This matter was also taken up with Deputy Prime Minister Quttubdin Hilal and the Afghan Foreign Minister when they visited Pakistan.

Public opinion in Pakistan holds President Rabbani and Professor Sayyaf, a coalition partner in the present government, ultimately responsible for these detentes. Mullah Salam belongs to Sayyaf's Ittehade-Islami.

According to an official spokesman at the Foreign Office, the Afghan government was reminded that among the criminal activities of Mullah Salam are firing from across the border with multi-barreled rocket launchers, mortars and automatic weapons on Frontier Corps posts in Balochistan at Qamardin Kaez, Badini and Kashatu. These attacks have resulted in damage to property and a number of casualties.

Mullah Salam was involved last March in the kidnapping of a Naik of Zhob Militia. Then in April he raided village Khanokai, burnin: chine and abducting seven employees of the Balochistan Development Authority. In June the same year, Chinese hydrologists were kidnapped from the Bostan area.

Though not mentioned in the official list of detentes, two Pakistani students were picked up from Kabul by the Commander of President Rabbani, Ahmed Shah Masood and taken to the Panjsher Valley.

Foreign Minister Sardar Assef Ali, who is visiting Saudi Arabia this week with the Director General of the Afghan Desk, is expected to bring up this issue with his counterpart in that government.

Ansar Abbasi adds: The Government of Pakistan has decided to close all channels other than the Foreign Office for the release of Deputy Commissioner Ziarat and others.

The government of Pakistan will now take up the issue only with the Afghan government. The Balochistan government has been directed not to hold any kind of informal dialogue with the Afghan commander, who is the kidnapper.

\section{PML(N) demands immediate reopening of embassy at Kabul}

F.P. Bureau Report

ISLAMABAD - A spokesman of the Pakistan Muslim League has demanded immediate reopening of the Pakistan embassy at Kabul.

In a statement issued here Saturday, the spokesman said it had been 40 years since the PPP government, "as part of its foreign dictated agenda", closed down the embassy and recalled the uplomatic staff.

At the time of taking this "unfortunate anti-national step", Foreign Minister Sardar Assef. had claimed that the step was being taken on 'technical' grounds and that the embassy would be reopened in the near future.
"The country has already suffered diplomatically and strategically due to this unwarranted closure and further damage to the nation's interests cannot be tolerated" the spokesman added.

He said the real reason for the closure of the embassy was to enable India to gain a foothold in Afghanistan and thereby provide that country the opportunity to increase its influence which had been non-existent for 14 years.

This was being done by the government in continuation of its policy of helping Indian strategic interest in the region to the detriment of Pakistan's interests as previously demonstrated by Benazir's help to Rajiv Gandhi on the Sikh issue, he alleged.

He said moreover, the absence of Pakistani diplomatic presence in Kabul helped in creating misunderstanding between the Pakistani and the Afghan nation which was the desire and goal of Pakistan's enemies.

The spokesman said it was ironic and contradictory for the government to offer to mediate between the government and opposition of Tajikistan while having no formal diplomatic presence in Afghanistan. He said the government must recognise that Pakistan's relations with Afghanistan was essential for its role in Central Asia. 
By WASEEM AFMAD SHAH

President Farooq Ahmad Leghari Monday urged the warring Afghan tactions to avoid bloodshed, because so long as peace was not restored in the war-torn Afghanistan. Islam could not be enforced in its true spirit.

$\mathrm{He}$. was addressing Afghan refugees at Kacha Garhi refugee camp on the first day of his two. day visit to Peshawar and tribal arees.

Leghari also urged the US, European states and the UN to start rehabilitation work in peaceful areas of Afghanistan. If they are scared of visiting Afghanistan. Pakistan is ready to offer manpower for this gigantic task, he added.

Pakistan is firm on its previous stance of non-interference in the internal affairs of other countries", Leghari said, adding "but it's our

\section{'Tribals to get fruits of democracy' \\ endeavour that the warring fac-} tions shun their differences in larger interest of the Afghan na. tion".

Leghari, who spoke throughout in Pushto language, said he was here to pay tributes to the gallant Afghans who gave a crushing defeat to a superpower despite all odds, fomenting the aggressor's disintegration.

"No one, at that time, believed that the Afghans will be able to stop the Russian invasion, as the Russians had nuclear and other modern weapons. But the Afghans proved that if one has true faith in Islamic teachings then he can face every power", he added.

Amidst slogans of "Pakistan, Afghanistan zindabad" and "Allah-0-Akbar", Leghari said it was heart-rendering that despite withdrawal of Soviet troops and fall of its puppet regime. Afghan factions were still fighting.

Leghari said a special UN enAfghanistan, met him telling that the Afghan problem would take time to be solved.

"Instead of sitting idle and waiting for peace, we should initiate reconstruction work in Afghanistan", he added.

"Its our policy not to interfere in the affairs of neighbouring countries, but when the Russian forces invaded Afghanistan, we considered it our religious, moral and human obligation to help our brothers and sisters in distress". he said. Even other countries, he added, warned that Pakistan would be destroyed in supporting Afghan fighters, but despite that Islamabad didn't withdraw its support.

He categorically stated that voy, Mahmud Mestiri who visited

\section{Leghari}

(Continued from Page ) represented the refugees, eulogised the services rendered by Pakistan during the Afghan jehad and thanked Leghari for visiting the camp.

Leghari, who was accompanied by acting governor, NWFP Khurshid Ali Khan, was received at the camp by commissioner Afghan refugees. Sang Marjan Khan. Latter he distributed gifts among the Afghan children.

APP adds: Leghari assured a tribal jirga that the government would strive to make tribesmen benefit from democracy without affecting their traditions. No system repugnant to their temperament would be enforced, he added.

Addressing a grand representative jirga of the Khyber Agency at Landi Kotal, the president said "it has always been our endeavour to introduce democtacy to the tribal areas, so that justice could be provided to them, but this would be done with prior consultation with the tribesmen". "Any democratic system introduced to the tribal areas would reflect the sentiments of the people of these areas", Leghari added.

He said the government would consult all the people living in the tribal areas before taking any de. cision, because a popular decision was always lasting and durable. He repeatedly said the government would not thrust its will on the tribesmen.

Leghari said development of the tribal areas was always the priority of the government, as the tribesmen had played a vital role in the creation and defence of the country. He expressed the hope that they would not hesitate to of- fer sacrifice in the future, also.

To bring the neglected and under developed areas at par with the developed areas of the country, was the constitutional obligation of the government, he said, adding any government ignoring the under-developed areas was deviating from the constitutional obligation. He said since the government wielded the support of the masses it would not hesitate fulfilling its constitutional obligation.

The tribal area, he said, had a peculiar position in the geography and history of the country, and father of the nation Quaid-i-Azam had rightly called the people of these areas as "sword-in-arm" of the country. He assured that all the promises made by the father of the nation with the tribesmen would be fulfilled by the government.

He said the authenticity of the election 1993, held under the supervision of the armed forces by the then interim government, had been admitted by politicians of all shades as such the government was a popularly-elected one.

Referring to the Afghan situa. tion, Leghari said entire Afghanistan had suffered due to war. Sources of development of Afghanistan have exhausted and even the capital, Kabul, has been destroyed totally.

"We should learn from this situation and should not deviate from the orders of God Almighty" adding, "although the valiant people of Afghanist m have achieved liberation, but ing is a matter of cort wrver, I am sure the peof Afghanistan would themst a decide their fatè as we do need interfer
Pakistan was not supporting any of the Afghan factions, and its efforts were aimed at bringing peace in Afghanistan. All the countries that helped Afghans in their jehad had different objec-j tives and motives such as Russian enmity, Islamic brotherhood and humanity, he said and added Pakistan also helped the Afghans as it considered their own broth ers.

He also reiterated the government's pledge to help Bosnians. Kashmiris, Afghans and Palestinians and added that it would not be cowed down by any external pressure, as in past for sake of restoration of democracy they (PPP) didn't surrender even to a dictatorial regime.

Earlier, an Afghan malik, who

(Continued on

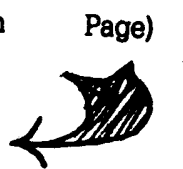

ence in their affairs", he added.

He said, the Britishers when interfered, unnecessarily, in India and the Soviets in Afghanistan their end was before the world. He assured that the government was ready to support Afghans so as to enable them stand on their feet. He said Pakistan had made it clear to Mestiri and other world leaders that Pakistan would provide every sort of support to the people of Afghanistan in their odd time. He expressed the hope that conditions in Afghanistan would soon return to normalcy.

FRONTIER POST

12 APR 1994 


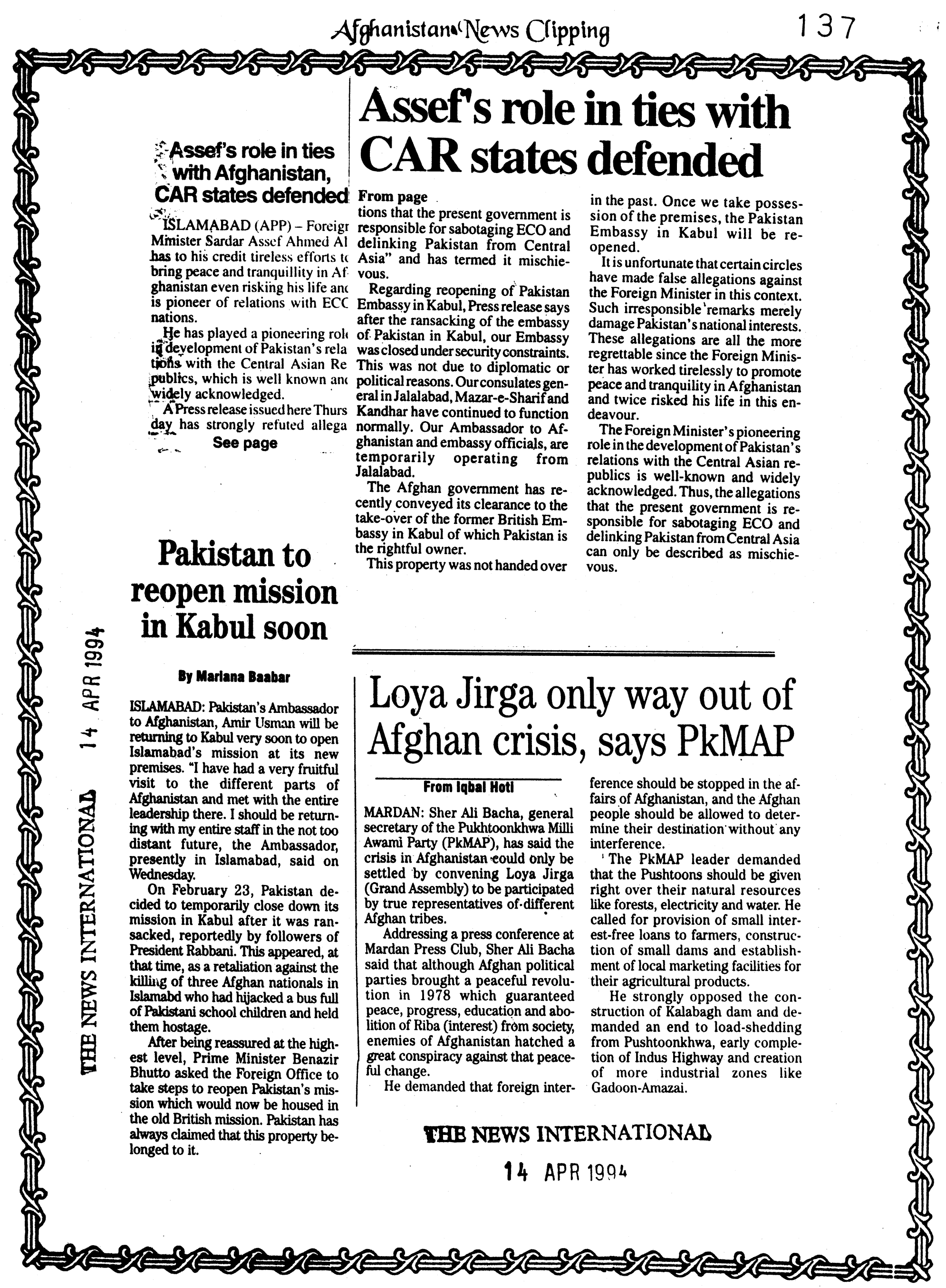




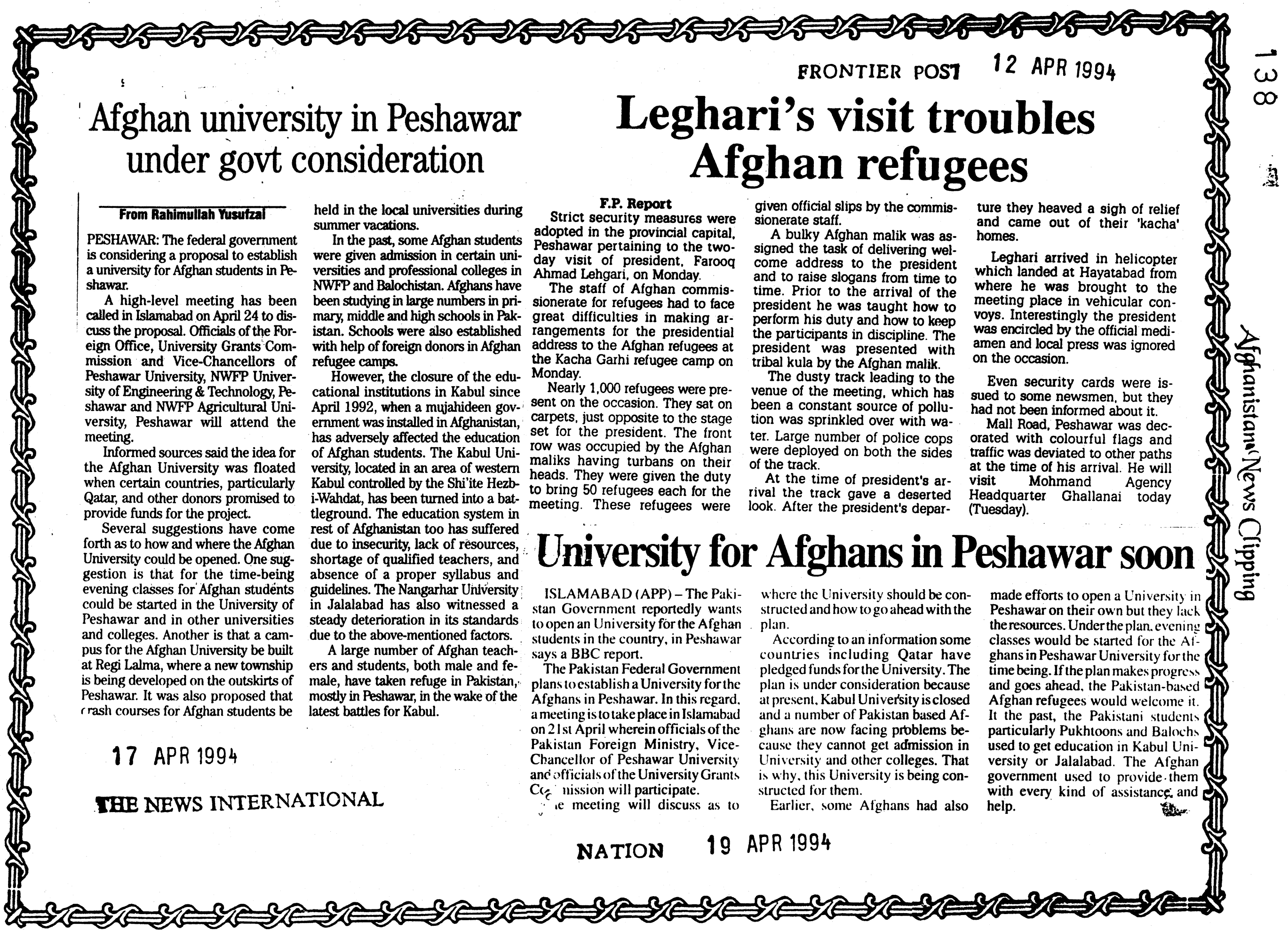




\section{Leghari appeals to Rabbani to work for truce}

ISLAMABAD (PPI) - President Faroog Ahmad Khan Leghari has said that the people of Pakistan take great pride in standing shoulder to shoulder with their Afghan brothers during the difficult period of Jehad and are immensely pained at the continued fighting in Afghanistan which has increased the sufferings through loss of innocent lives and economic devastation.

In a message to Prof. Burhanuddin Rabbani of Afghanistan on the auspicious occasion of Islamic Revolution President Leghari said "Once again I seek this opportunity to appeal to you to use your high office statitre and wisdom in taking appropriate steps together with other Afghan leaders which would bring about and immediate cease fire and help in reviving the process of conciliation". The message said "On behalf of the government and people of Pakistan and my own behalf, I have grea pleasure in extending our warm and sincere greetings to Your Excellency and to the brotherly people of Af- ghanistan on the auspicious occasion of the Islamic revolution day. The people of Pakistan take great pride in standing shoulder to shouling the difficult and perilous period of the Jehad and.are immensely pained at the continued fighting in Afghanistan which has increased the Afghanistan whic sufferings through loss of innocent lives and economic devastation. The ity.

Once again, I seek this opportunity to appeal to Your Excellency, to use your high in taking appropriate steps, together with other Afghan leaders which would bring about an immediate cease-fire and help in reviving the process of conciliation.

I wish to take this opportunity to expiess my sincere wishes for your excellency's personal health and happiness and offer my prayers for the establishment of durable peace in the brotherly country of Afghanistan. der with their Afghan brothers dur need of the hour is peace and stabil-

\section{Govt plans to involve NGOs in food supply to Afghanistan}

\section{By Ansar Abbasi}

ISLAMABAD: The fedelal government has so far failed (1) evolve a foolproof system to isitle permits for transportation of fond to Afghanistan.

A number of recommendations to minimise chances of misuse of these permits and curb wheat smuggling across the Pak-Afghan border have been submitted to the cabinet for a decision. However, many officials concern... seem dissatisfied with these proposals as they empower the chie? commissioner for the Afghan Refugees in Islamabad to issue the food permits and take away powers foum the interior division and the NWFP government.

According to well informed official sources, the comn" . ce division and SAFRON will mui...illy decide how much food shor'd be transported to Afghanistan

The food permits " 'I be issued mainly to NGOs engay. 11 in the welfare of the Afghan rein:tees. However, the nominces of the Afghan government through the Foreig Office will also get thi nermits.

Sources see nany "ropholes in these recommendatio: and say the $\mathrm{N}($ OOs are reluctant i.. transport food from l'akistan to i ghamistan.
These NGOs, the sources said, think that food transportation is not their job as they work for welfare and rehabilitation of the Aghan nationals. In case the guvernment gives food permits to the NGOs, they will sell them to some third party, causing increase in the wheat price in Afghanistan as was happened in the past.

The food permits scandal surfaced when the wheat price in Afghanistan shot up and its supply to different parts was disrupted. Permits of almost 123,000 tonnes of wheat were issued to fake NGOs which were only supposed to take limited food for their persons only.

Sources said the government's plan to assign the food transportation responsibility to NGOs would not control the wheat price in Afghanistan because these permits would be sold to several other parties.

SAFRON minister Abdul Qayyum Khan, when contacted, conceded that leakage in the process could not be completely eliminated, but the government was sincerely conidering to make the process smooth by involving the NGOs.

He denied that the NGOs were elurtant to do the job, but admit(erl that the permits would be sold (6) other hands. He said the govern-

ment wanted the NGOs to transport food to Arghanistan through trans porters who enjoyed good relations with all fighting Afghan groups so that food could be supplied to all those parts where it was required. He said that currently the Inter Services Intelligence, the World Food Programme and the UNHCR were transporting food to the warbattered country and they did not need any permit. The permits were not being issued, he said, but through illegal means 80 to 90 trucks of wheat were sinuggled to Afghanistan everyday from Balochistan, North and South Waziristan and Kurram Agency.

The minister said he did not ssue any permit since he assumed the office and was considering to evolve a strategy to ensure that the Afghans could get food at reasonable price. He said a set of recommendations in this colmection had been submitted to the cabinet which would finally decide the mechanism to issue the food permits.

The minister said Afghanistan needed 400,000 tonnes of wheat every year, out of which Kazakhstan was supplying 40,000 tonnes the World Food Programime 150,,000 tonnes and Pakistan was supplying the rest.

YHB NEWS INTERNATIONAD

24 APR 1994

NATION 25 APR 1994

IHB NEWS INTERNATIONAD_ 24 APR 1994 
Saloem Khan, general secretary. provincial Urban Development Board, Officers Asecciation hea dilated on the venomous statement of Barrister Bacha on the suspension of PDA officials appearing in a section of the prees.

Saleem Khan said the statement of the Barrister emanate from the long standing dispute dragging on between the PDA and the wife of the Barrister, Mrs Khush Bakht Bacha, over the illegal encroachment of residential land and a huge public sum outstanding against the lady.

She was allotted additional residential land measuring 7702 sq feet on June 30, 1987 and was asked to deposit the sale price amounting to $R s 1,18,819 /$ - by July 15,1987 , failing which the officer was to be canceled Applying dully_dailying tactics she withheld payment until she was served final notice on February 4, 1993 and thereafter only part payment was made.

On request of the lady that the extra land allotted to her was less than the one in her actual pos session the site was remeasured. Bacha was also present during measurement of the site. It was revealed that the lady had occupied $2440 \mathrm{Sq}$ feet in addition to what was left of the balance which she was to pay in 1987. Having failed to use all the delaying tactics at her command over a period of 5 years (1987-1993) the lady finally went to court.

Bacha is a lawyer and a claimant of Pukhtoon leadership. Hayatabad is a project of Pukhtoon people. Withholding public money for five years or illegal occupation of prized chunk of residential land amount to placing a spanner in the development of this model township for which every Pukhtoon is rightfully proud.

Instead of persuading his wife, to deposit the public money or release illegal occupation of the extra land adjacent to her hours, Bacha has let lose his wrath on the hapless PDA officials.

Saleem has advised Bacha to keep the state interest above his personal gains.

Following is the copy of notice issued to Mrs Bacha: It is intimated to you through this notice, that you were allotted additional land measuring $7702 \mathrm{Sft}$ vide this office letter No. 39/G $3 / 2 \cdot K / 32$, dated 30.6 .1987 and were requested to deposit the sale price of additional land amounting to Rs $1,181,819 /$ - upto 15.7.1987 failing which the offer was to be cancelled but you deliberately ignored for a long time until a reminder was issued to you vide this office letter No. 39/G. $3 / 2-\mathrm{K} / 44$ dated 4.2.1993. In compliance you deposited the sum of Rs $1,18,819 /$ - as price of the additional land but again refrained from making payment of surcharge amounting to Rs 66,408 . that has accrued upto 2.3 .1993 due to non compliance of the orders referred to above.

On 26.1.1993 you applied for is. suing an amended possession certificate stating that the area mentioned in the possession certificate (No.3407, dated 4.2.1987) differed from that on site. The housing officer (site) was requested to give revised possession but it transpired that you were in actual possession of total area of 21017 Sft as against the authorised $18577 \mathrm{Sft}$.

Thus you have made an encroachment on PDA land measur. ing 2440 Sft without approval and proper allotment from the compe. tent authority. On a visit to this office when your husband who claimed to be your representative was informed of the situation he pressed for remeasurement at site. Accordingly the whole area was remeasured in your presence as well as in presence of your hus band by Hajl Saifullah Khan, chlef draftsman of this office who confirmed that an area of $21017 \mathrm{Sft}$ was in your occupation instead of the authorised 18577 Sft as such! you have been in an illegal possession of PDA's land and have encroached upon an excessive area of $2440 \mathrm{St}$.

You are therefore, directed to please remove the encroachment immediately or deposit the sale price of additional land measuring 2440 Sft at the prevailing rate of Phase-VII which is Rs 2,60,000/per kanal within 15 days of the re ceipt of this notice.

It may please be noted that if you fail to deposit a sum of Rs $1,16,617 /-$ + surcharge referred to in para-1 on account of sale price of additional and upto 30.7.1993 then the above offer shall stand rescind, the additional land shall be taken back and the encroachment shall be removed through the building control agency of this authority.

This may also be treated as final notice.

\section{FRONTIER POST 27 APR 1994}

\section{Rocketi may strike again: security tightened}

\section{Rocketi issue: IIA to pack up \\ F.P. Report}

The federal government has asked the provincial governments of NWFP and Balochistan to close all the offices of Ittehad-i-Islami. Afghanistan, headed by Prof. Abdul Rab Rasool Sayyaf, in their respective provinces, highly placed sources said on Thursday.

The federal government also asked the two provincial govern ments to withdraw all the facilities being provided to the Ittehad1-Islami and its representatives, the source added.

The source further said that the federal government's directive was based on the decision taken by the federal cabinet recently.

It is learnt that the federal govennment has ample evidence that the infamous Afghan commander, Mullah Rocketi was enjoying the blessing of the Ittehad-i-Islami. Rocketi, the notorious Afghan commander has kept many Pakistani officials including a deputy commissioner and two Chinese engineers in his custody for ransom.

It was a matter of disappointment that the Ittehad-i-Islami did not extend any help to get the captives released, the sources quoted an official in Islamabad as saying.

The Ittehad has denied reports that it has any connections with Rocketi but the federal government is not willing to accept this contention, source concluded.

FRONTIER POST

29 APR 1994
PISHIN (APP)-Under the instructions of the Federal Government the Frontier Corps has tightened security arrangements in Pishin, Qila Abdullah. Ziarat, Qila Saifullah and Zhob districts and extensive and sudden checking of vehicles is being carried out to check any inuse to create law and order problem in these areas.

Measures have been taken on the reports that notorious outlaw Mullah Salam Rocketi may strike again through his gang to 'kighnap some official or politician of this area.

The Frontier Corps has taken over the responsibility of maintaining law and order in the above districts and in this connection emergency centres have been set up which would be empowered to use helicoplers in emergency cases. 


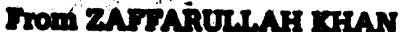

ISLAMABAD - One of the coauthors of the country's Afghan policy since earty 708, Maj. Gen. (Rotd) Nasiruillah Babar considers, the return of the elderly Afghan monarch. Zahir Shah as the sole unifying option to restore peace and re-build the war torn Afghanistan.

I brought the mujahideen to Pakistan in early 708 for training. launched them in Panj Sher to put on test their skills and give a sig. nal to Sardar Daud about - Pakistan's potential to create disturbance in his country. Later, facilitated them to establish contacts with the Americans in May 1979. Still I can serve as a bridge to bring back the exiled Afghan monarch Zahir Shah".

The interior minister observed Had Cen. Zia followed political track along with the military strategy as wo had envisioned. then Kabul would not have burnt today". Secondly, the issue of illegal Arab immigrants would never have arisen, if the late military dictator had not 'abused the Afghan situation for his legitimaCy and survival. "Even in mid-70s, the Libyan ambassador had contacted us with the idea of extending help in tackling the Afghan

30 APR 1994

BRONTIER rOST tailed interview: hopes. mer Soviet Union generation change was threatening the old guard. In China after Mao his heirs were dominating, in Iran there was leadership gap as after Raza Shah there was a mist about his possible replacement/heir. Amid such signs after Indo-Pak war of 1971, we appreciated the situation in a way that could ensure Pakistan's hold over possible course of events.

Secondly, Bhutto had visited the Federally Administered Tribal Areas (FATA), where the writ of the government was just non-ex-

\section{Interview}

Babar Post, Maj. Gen. (Retd). elaborated various other dimensions of the Afghan situation Here are excerpts from his de-

FP: You are viewed as the ar. chitect of Pakistan's Afghan policy since 70s. What was your vision and where it went wrong as today Afghanistan is a story of pain and agony with ruined

NB: I wont say that Bhutto was the architect of Afghan policy. He had a futuristic vision and the entire region was witnessing changes as Sardar Daud had toppled Zahir Shah and the continuity of system had broken. In for- thus we followed both the political and military tracks. But later general Zia and the ISI narrowed the approach by confining it to a mere military option and today all groups are in wilderness.

How did you launch your strategy and what was the immediate feedback.

After imparting formal training. we launched them in Panj Sher is 1975. At that time we had two considerations; first to test the abilities of this lot and secondly to send a strong signal to Sardar ' Daud that we had learnt to play! on the same music which we. were facing in the shape of bomb blasts and this strategy worked. Sardar Daud was willing to talk. on the Durand Line as it became a problem for him.

Along with this strategy, we launched a massive socio-economic development plan in the ' FATA. The development budget, for these areas was merely Rs. 44 lakhs in 1973 which reached around Rs. 30 crores in 1977 . We? awarded transport permits to the ) people of FATA with a view to integrate them with the Pakistani society both economically and socially. Similarly, we prepared a comprehensive policy to intro-

(Continued on Page 2) ' See Drext Pago
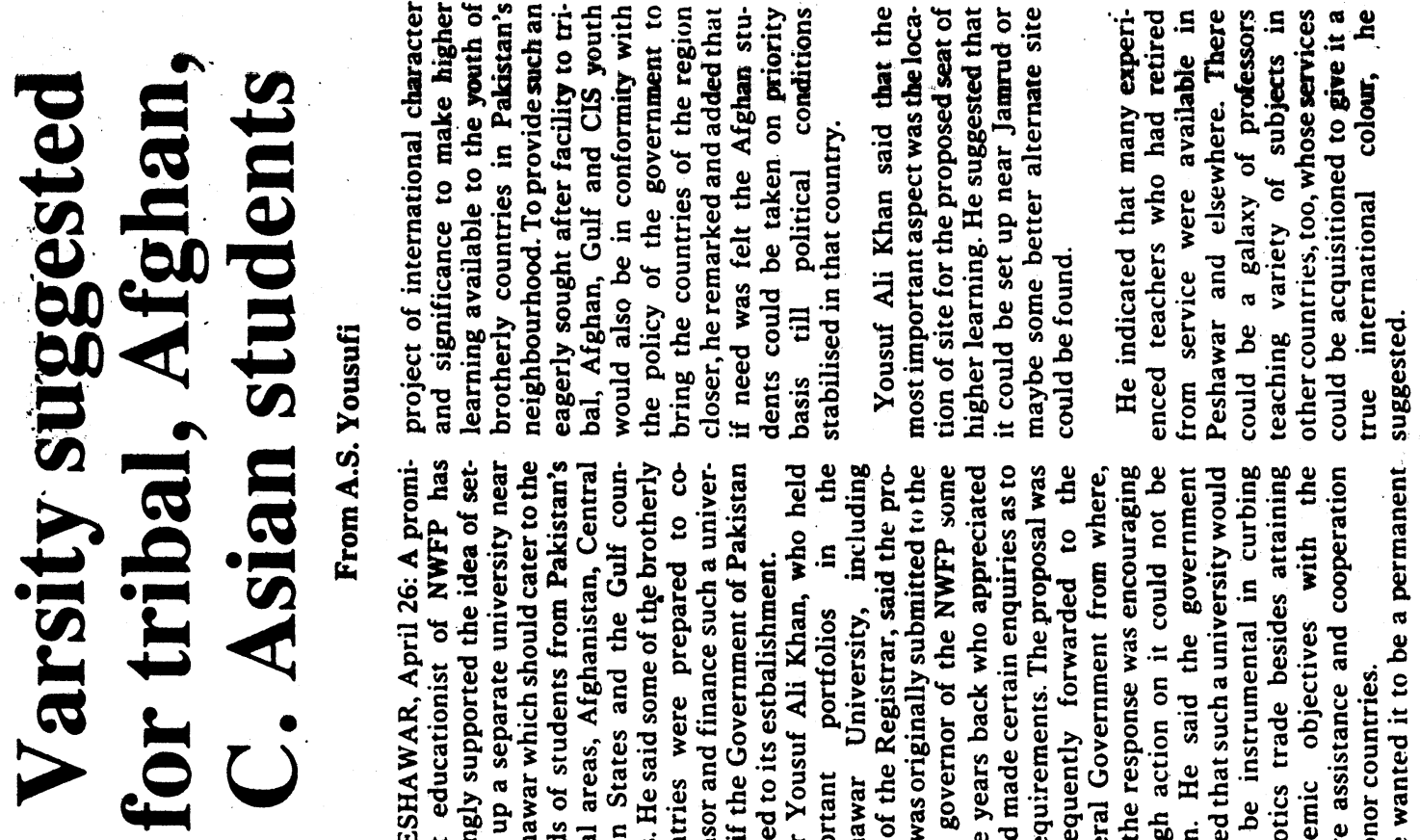

志

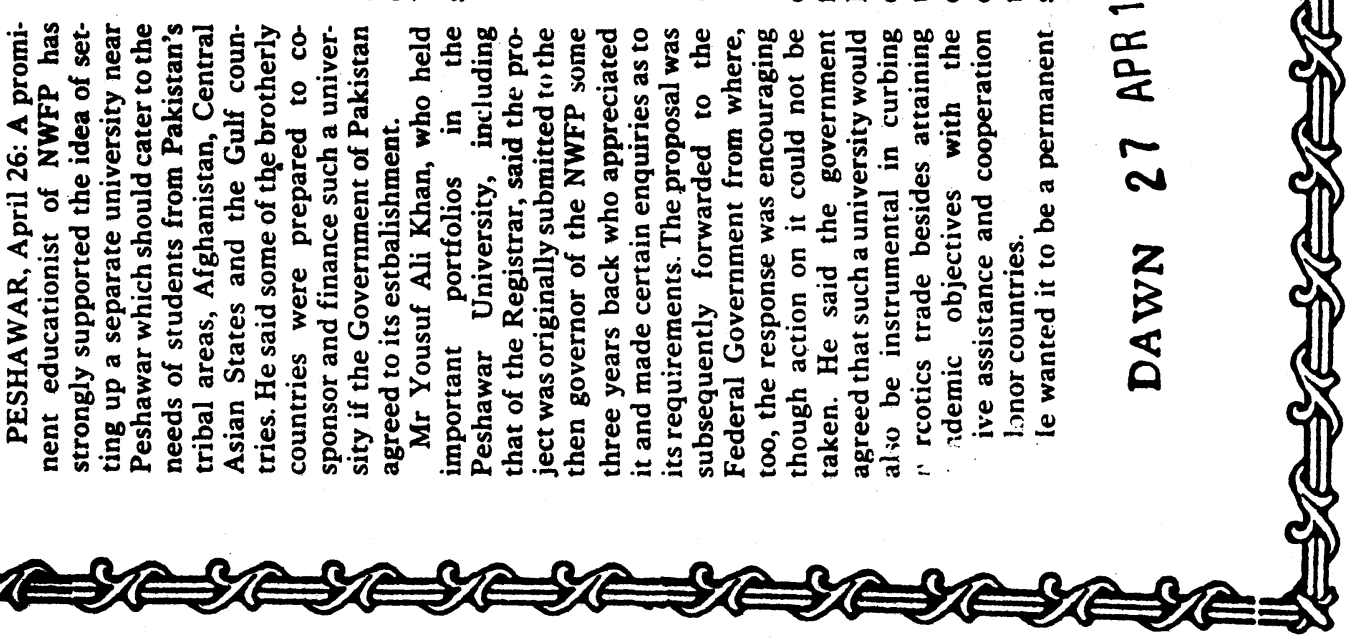




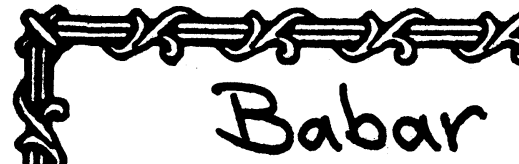

(Continued from Page 1)

duce the adult franchise there in 1977 along with accommodating the FATA people in the provincial assembly.

At that time Sardar Daud requested Pakistan to delay these political reforms for a short period But after July 1977's coup not only these reforms were abandoned. rather the aid to the Afghans was stopped, which resulted in creation of various factions. Some of them then contacted Saudi Arabia, a few Iran and I facilitated them to meet the Americans in May 1979, when I was released from jail.

Don't you think these links brought lethal weapons and sub. sequent disaster.

In fact when we launched our Afghan policy at that time we had assessment about every potential leader and we simultaneously followed the political as wells the militant track. It will be interesting to pinpoint here that in Afghanistan the carrying of arms was banned since the days of Amir Abdur Rahman, only Suleman Khan were allowed to possess and carry them. Thus many of the Afghans had no proper training to use modern weapons. But present mess is the result of General Zia's limited vision of confining the Afghan policy only to the military option. The said policy's failure became visible when after Geneva accord and the following developments, there was no authority to assert itself and control the events.

You have frequently pleaded in favour of Zahir Shah's option. What is the rationale behind this.

What Afghanistan desperately needs is some sort of central authority. I honestly feel Zahir Shah as the constitutional monarch. In 1976 I sent a few Afghans to talk to him and he agreed to come back but he said he would first consult Shah-i-Iran and Anwar Sadaat. This efforts was hampered by the military coup. Later. in 1988 when the PPP came into power, we initiated the same suggestion but at that time all other countries involved in the Afghan situation exerted pressure. We didn't accept that and rather asked them to go inside Afghanistan. Kuner was a safe area at that time. But instead of opting for international personality like Zahir Shah, they tried to capture Jalalabad which resulted in a fiasco.

In 1989 and 1990 when we talked about Zahir Shah both the army and then president, Ghulam Ishaq Khan was opposed to that. After our ouster, in 1991 I offered an intelligence service's man who met me at a marriage party that I

\section{can lacilitate a meeting with} Zahir Shah in Geneva. But the short-sighted people went for Peshawar and Islamabad accords and such people started taking decision as were not fully aware about Afghanistan. Now once again I have offered to bring back Zahir Shah as I am confident that even his 'grave' could serve as a source of unification among the Afghans

Unlike other war theaters, why have the Americans and other significant countries forgotten Afghanistan?

They had their own interests. The American's sole interest was to destabilise the former Sovie Union and they achieved it. While the ISI's vision was limited and they thought that after the with drawal of the Russians, Najib would collapse. But on the con trary he had consolidated. We staged the drama of Gen. Tanal merely to convince them that the military option. was impossible but they failed to learn any lesson or draw any conclusion.

Recently the Pakistani govern ment sealed the Afghan border What were the urgent factors to do so?

Look, the Jamaat-i-Islami was saying that the Ummah had united and there was no Durand Line. Similarly, the ANP was saying that now "Pukhtoonistan" had been created in reverse. But we don't subscribe to these views. Both Pakistan and Afghanistan are two sovereign states and we have to assert this fact. That is why we had to check the borders.

Refugees problem is the permanent gift of the Afghan crisis. Did you have any idea about the complexity of this aspect when you formulated your Afghan policy in early 70 s.

People have been coming from the north in the wake of every movement and historical invasion but at that time the canvass was both the Indus and the Ganges planes. Many of them used to go back but a significant number used to absorb itself in various 'bastis'. Similarly many of them would go back provided there was peace in their homeland However, a few would settle here as it won't be a difficult process due to certain cultural commonal-

Being champions of the world peace, why don't the international donors also reluctant to launch any reconstruction project in Afghanistan.

This is impossible unless there is peace in Afghanistan. We have asked the Afghan president and the premier to forget about factional war and launch a massive struction of that war-torn country. We are willing to provide them the required manpower and various folios. But this help won't serve any purpose unless there is peace and stability in Afghanistan. Only after peace can one solicit the support of the in ternational donors in this vital area.

Many people talk about elections in Afghanistan and installa tion of a representative govern ment there. Is it an achievable option.

Yes, it is feasible as $80 \%$ population of Afghanistan wants change and secondly many of them have seen at least four elections in Pakistan since 1985. The young Afghans have not only observed this process, rather they have a quest for that in their own homeland.

The issue of various Arab NGOs has often hit the headlines. How did this problem arise?

When we embarked on our Afghan policy, the Libyan ambassador contacted us to extend sup port but Zulfiqar Ali Bhutto re fused to allow the Pakistani land During the days of Gen. Zia these Arabs poured into Pakistan not to uphold any Islamic cause but to strengthen the ties of "Akhwanul Muslemeen", so that they can work in own countries after get ting enough experience of the militant struggle.

As a result of this unwise policy, not only was Pakistan threat ened to be declared as a state allegedly patronising terrorism rather our Muslim brethren in Egypt, Algeria and Tunisia com plained about these militants. Our government is seriously checking them and we have given them a deadline to go to any third coun try.

Former premier, Nawaz Sharif linked his Peshawar-Islamabad motorway project with the possibilities of exploring trade with the Central Asjan states. How do you view this?

This is highly irrational. You can afford expensive motorways only then, when there is peace in Afghanistan. Qtherwise it will be sheer waste of resources. Our convoys can't go beyond Jalalabad, how can you talk about the Central Asia.

We have started tasting the fruit of our Afghan policy in the shape of school bus's hijacking and attack on our embassy in Kabul. How do you view these development?

We have extended hospitality to the Afghans for 13 years. But I

feel the bus hijackers were the 'Khad' people and were motivated by India. God forbid, if any unpleasant thing had happened, it would have created the worst law and order situation. So far as the attack on Pakistan embassy in Kabul is concerned, it was the reaction of a few people.

Some people link the recent political developments in the NWFP to some changes in the broad Afghan policy. What is your opinion?

No, it has nothing to do with the Afghan situation.

Then why did you shift the 'food permits' from provincial to the federal prerogative.

Foreign trade has always been 1 a federal subject. It was only in 1992 that the Afghan refugees started going back. The federal government delegate its powers to the provincial government. But this was being highly abused. thus the federal government took these powers back. You will be surprised to know that during this period the provincial government awarded food export permits even to those NGOs which existed only on papers.

The adult franchise for the FATA was part of your strategy of 70 s and still is part of your party's manifesto. Why hasn't it materialised as yet?

It is still a part of our policy and in next general elections you will see democracy functional in the FATA. We have no haste in this regard. Currently, the FATA is represented by eight MNAs from the area. And there is consensus about the introduction of adult ranchise in the FATA.

How do you visualise the fu. ture of Afghanistan?

We should pray for peace there. There is a great potential of progress in Afghanistan. There is also a chance for democracy provided there is national consensus. For that we would have to bring Karmal, Najeeb, Zahir Shah and all 'mujahideen organisations' on one table to hammer out some workable formula for the future of Afghanistan.

30 APR 1994

ERONTIER POST 


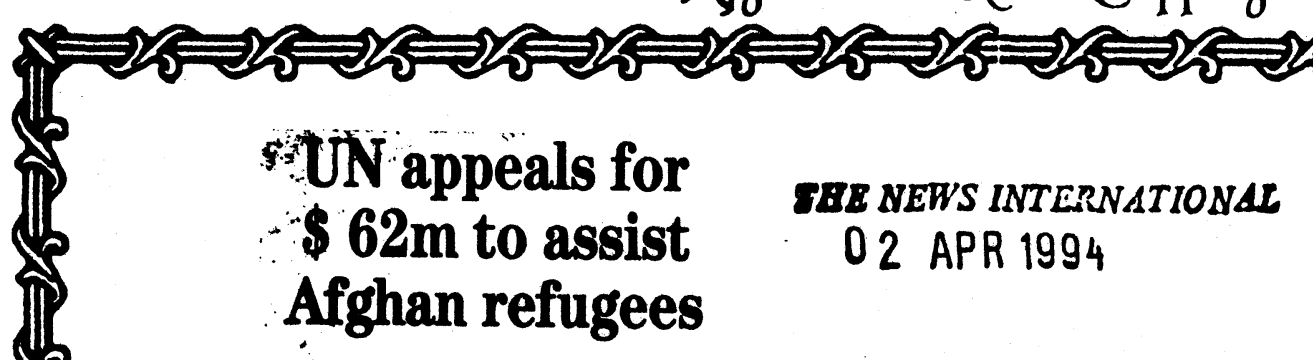

\section{Dy our cerreapondomt}

ISLAMABAD: The UN on Wednesday issued an appeal for 62 million dollars to meet the most urgent humanitarian needs of the Afghan people for the next six months.

The appeal was made by the UN Coordinator of Humanitarian Assis. tance to Afghanistan, I Sotirios Mousouris, at a news conference in Istamabad. The continuing fighting in Kabul, he said, was causing terrible human suffering, and hundreds of thousands of Afghans were dependent on aid from the US and humanitarian organisations for their survival.

He said 25.5 million US dollars were needed to look after refugees displaced from Kabul. There were over 125,000 such people in Jalalabad. Another 36.6 million dollars were needed for the ongoing humanitarian programmes including mine clearance, voluntary repatriation, food aid, health, water supply, power and sanitation, emergency agricultural inputs, social programmes and management support.
Mr Mousouris said the ICRC estimated that 2,500 people had been killed and about 17,000 injured in fighting in Kabul since January.

He feared that unless necessary medical assistance was provided at refugee camps in Jalalabad, there was danger of the spread of epidemic diseases like cholera.

To a question, he said that about 300,000 Afghan refugees from Iran and 100,000 from Pakistan would be voluntarily repatriated during the current year.

Meanwhile, continued fighting in and around Kabul is forcing people to run for shelter and there is a fresh influx of Afghan refugees to Pakistan.

Entry to Pakistan for Afghans is still officially restricted to those with valid travel documents and those allowed to enter on humanitarian grounds. Despite this, the UNHCR border monitors have registered 455 families comprising 2,836 people, as well as 3,720 individuals, who arrived via Torkham on humanitarian grounds during the first two weeks of April.
UNESCO calls

\section{on dealers to} respect Afghan art heritage

PARIS (AFP) - UNESCO direc-

tor general Federico Mayor called Wednesday on art dealers and collectors to refrain from acquiring objects that formed part of Afghanistan's cultural heritage but were looted from Kabul's central museum last November.

The international art market has recently begun trading in articles from Afghanistan that have found their way to the west after a rocket attack on the museum enabled looters to make off with many valuable items.

Officials of the UN Educational, Scientific and Cultura Organisation warned that "looters stripped the national musuem in Kabul, the Jellalabad museum was destroyed and several art objects were sold in the west." The loss to the Asian country's heritage was "massive", they said in a statement.

Mayor called on dealers and collectors to "respect scrupulously the interests of the Afghan people by refraining from acquiring objects that might have been stolen from them"

UNESCO said that dealers and collectors could check any items that were offered to them against an inventory that it possesses of the items that were stored in the Kabul museum at the time of the rocket attack.

\section{Afghans themselves should solve conflict: Mestiri}

ISLAMABAD, April 9: The UN peace mission headed by Mehmoud Mestiri is continuing talks and consultations with the Pakistan-based Afghans and might also pay a visit to other Afghan provinces.

In an interview with VOA John Mert, the spokesman of the UN special envoy, Mehmoud Mestiri said that besides meeting the Afghan leaders, Mr Mestiri also held talks with representatives of different groups including representatives of the women organisation in Kabul. He said the visit of Mr Mes. tiri is aimed at holding wide-ranging talks and consultations. It means that he is not only meeting the leaders rather he is meeting all segments of the society including intellectuals, Ulema and women to know their views and find ways and means for a practicable solution to the Afghan conflict.

Although, Mr Mestiri had expressed optimism few days back ind said that the peace would be announced within few days yet his spokesman, John Mert was cauti ous in this regard and said that one should not attach great expecta. tions with the visit and consulta tions. He added that they are in the beginning of their journey and there should be more talks and con. sultations.

He further said Mr Mestiri is likely to visit Mazar-e-Sharif and Herat next week. The spokesman neither ruled out nor confirmed the possibilities of talks with the former Afghan monarch, Moham. mad Zahir Shah.

In reply to a question about the Loya Jirga, the spokesman said that they are making efforts to know as to what is the common aspiration of the people of Afghanistan. He said that Mr. Mes tiri has held talks with a number of leaders and other Afghans. All the Afghans have their own views and plans for the solution of the problem. However, there are also some identical joints in their views.

He said one of their jobs is to coordinate such identical points and take immediate step on the basis of these points. The spokesman said that the issue of Loya Jirga is premature. He said that now they are listening to the people and any final solution to the Afghan conflict should be found by the Afghans themselves.

The spokesman said that at the end of the visit, Mr. Mestiri will submit his report to the UN Secretary General and the UN Security Council will also consider it. He said that the ongoing situation is not acceptable to international community. Mr. John Mert said that the United Nations wants the Afghans to realise that they are not alone in the crisis and hardship and the United Nations is helping them to put an end to thr isis APP 
ISLAMABAD (APP) - The United Nations on Wednesday issued an appeal for 62 million dollars to meet the most urgent humanitarian needs of the Afghan people for the period April 1 to September 30, 1994.

Sotirios Mousouris, coordinator of humanitarian assistance to Afghanistan addressing a news conference here said the continuing fighting in Kabul was causing terrible human suffering and hundreds of thousands of Afghans depended on aid from the UN and other humanitarian organisations for their survival.

Mousouris said part one of the appeal concentrated on the crisis in Kabul after fierce fighting erupted there on January 1 that still continues with brief respites.

It has brought unprecedented human suffering and destruction and triggered a huge exodus of destitute people. Hundreds of thousands people are homeless. Tens of thousands of the remaining population in Kabul are displaced.

Malnutrition and disease lurk around the corner. The ICRC estimates that 2,500 people have been killed, and some 17,000 injured. After these latest events the humanitarian challenge facing the international community has dramatically changed.

During the next six months, WFP aims to deliver 25,700 tonnes of food for 300,000 dis-

\section{UN appeal for Afghan peace}

UNITED NATIONS (APP) The United Nations on Friday issued a fresh appeal for peace in Afghanistan and said that continuing fighting in Kabul and other parts of the country remained an issue of utmost concern to the entire international community.

A spokesman for the UN special mission to Afghanistan has said the international community and the Afghan people hope that the leaders of Afghanistan will find ways to resolve their differences. He said the UN special mission was committed to assisting in this process as a neutral party and appreciated the expressions of support for its role from Afghan leaders and groups it had met. placed persons in Kabul: Drugs and medical supplies for hospitals will be provided by WHO and UNICEF.

Mousouris, who just returned from Afghanistan after visiting many cities, said in the Sar Shahi camp near Jalalabad alone', 80,000 uprooted people from Kabul were living. The other three camps (Mumtaz, Hadda Farm and Samarkhel) accommodate 45,000 people.

The UN agencies, together with the ICRC and a number of NGOs are helping these displaced families. Shelter and household materials are supplied by UNHCR. Wheat flour and other food items, food-for-work and vulnerable group feeding are provided by WFP. Healthcare programme are coordinated by WHO and UNICEF. Immunisation and supplementary feeding activities are supported by UNICEF, which is also coordinating establishment of a water supply system at Sar Shahi. Mines and unexploded ordnance in the area around camps have been cleared by UN. OCHA teams.

The appeal seeks funds to provide relief assistance for up to 200,000 displaced persons in camps in Jalalabad over the next six months.

In addition to those in camps, an estimated 100,000 displaced persons from Kabul are staying with friends or in rented accom-

\section{APR 1994 FRONTIER POST}

He said the UN mission was listening to the views of the Afghan people. The UN had not taken positions or made any judgements on the issues raised during its consultations.

The spokesman said Mehmoud Mestiri believed that the only way to bring a durable peace to Afghanistan was through the widest possible dialogue with representatives of all people of Afghanistan who suffered for so long in their heroic resistance to foreign occupation.

He said Mestiri had already met President Rabbani. Prime Minister Hekmatyar and many other leaders and was happy with the constructive exchanges with these leaders which focused on ways of ending the conflict in Afghanistan. modation in Jalalabad. Many benefit from the WFP's subsidise bread programme.

A total of 25.5 million dollar is urgently required to carry out the programmes in part one of the appeal.

As part of ongoing humanitarian programmes the UN agencies require new contributions totalling 36.6 million dollars for mine clearance (dollar 5.4 million), voluntary repatriation (dollar 16.1 million), food aid (dollar 2.5 million), health (dollar 2.8 million), water supply, power and sanitation (dollar 780,000), emergency agricultural inputs (dollar 4.2 million), emergency support for social programmes (dollar 2.2 million) and for coordination and relief management support it requires dollar 2.2 million.

As part of its voluntary repatriation programme the UN expects about 400,000 Afghans may return home from Iran and Pakistan this year.

Mousouris said up to 300,000 Afghans might return from Iran and 100,000 from Pakistan in 1994. Returning refugees will be given cash and food grants by UNHCR and WFP and returnee committees will be assisted.

He said assistance with transport in Iran to the border will be provided. Dollar 16.1 million was required for the voluntary repatriation programme, Mousouris added.

Meanwhile, the head of the UN peace mission for Afghanistan. Mehmood Mestiri, met a number of Afghans in Quetta, and Kandahar the other day.

In an interview with the VOA, John Meltz, the spokesman of Mestiri said that the people were talking about peace and reconstruction of their country.

He said the peace mission visited a number of Afghan provinces. All the people generally wanted permanent peace and a government to end the ongoing situation in Afghanistan. He said the situation was not the same in all these provinces. Peace is prevailing in some provinces and there are provinces where fighting is not going.

ERONTIER POST.

28 APR 1994 


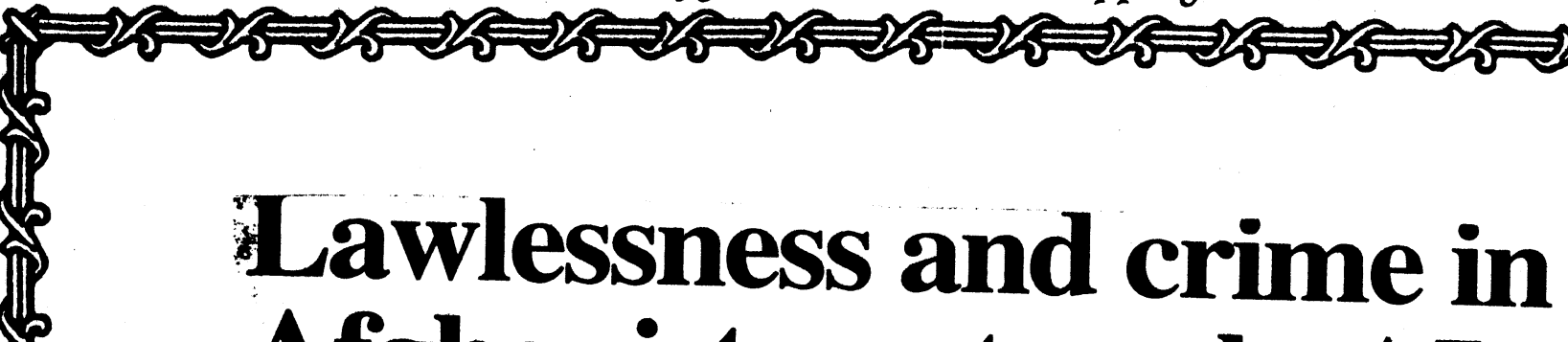 Afghanistan at peak: AI}

\section{From Our Correspondent}

PESHAWAR-The Amnesty International has expressed resentment at the frequent violation of human rights by the warring Afghan factions in Kabuil.

The Amnesty International in a report said that lawlessness in Kabul has become the worst while the unarmed innocent citizens are totally insecure and women are being dishonoured by the warring factions. The Amnesty reports state that heinous crimes against the civilians and even against children have become a coutine.Amnesty further states that a large number of people are being politically victimised by their opponents. Kidnapping for ransom and political vendetta is rampant in $\mathrm{Ka}$ bul. It alleged that in the last two years, thousands of people were kidnapped and majority of them were tortured. Hundreds of people were botally murdered by the armed sards of warring factions.
Amnesty International in its reports pointed out several cases of kidnapping from Afghan capital. On January 1, 1994, President Prof Burhanuddin Rabbani had sent one of his aides Mr Najamuddin Musleh for talks with Rashid Dostam to resolve the differences. He was abducted by the militia forces and is still a captive.

It further states that one Army officer Mr Ajmal Ishaq was arrested by the Jamiate Islami Mujahideen from his house. No one knew about Ajmal Ishaq and now his family members have left their homes in Kabul either for Pakistan or Jalalabad. It was apprehended that Jamiate Islami Mujahideen have killed Ajmal Ishaq. In November last, three children were abducted by armed guards of a faction from their home at Karta-iSakhi. Parents of these children have failed to get them released. The reports further said that armed guards of Hizbe Wahdat have abducted one Muhammad Yar from his house at

\section{NATION}

\section{APR 1994}

\section{School books for Afghanistan}

From Our Correspondent

PESHAWAR - A senior USAID official from Islamabad on Tuesday witnessed the packing and loading of the latest installment of primary and secondary school textbooks bound for the schools of Afghanistan.

USAID launched an enormous project in January this year to produce, print and distribute three million textbooks for the children of Afghanistan.

- USAID's Chief of Afghan field operations, Mr Mark Ward, visited the University of Nerbraska at Omaha (UNO) and International Rescue Committee (IRC) offices here today, where the books have been developed, printed and packed for transporation to schools and several provincial education directorates inside Afghanistan, Mr Ward said that the USAID-funded Education sector Support Project (ESSP) has invested more than $\$ 40$ million in the children of Afghanistan since 19.5.
Macroyam recently. Muhammad Yar, along with his six children is still in custody of the Hizbe Wahdat Mujahideen and his other relatives have left the Afghan capital failing to pay heavy ransom for their release.

The heinous crimes are not only committed against common citizens but the newsmen as well. The Amnesty report says that an Afghan journalist was arrested by the Jamiat Islami Mujahideen in October 1992. The said Afghan journalist was stated still to be in custody of the Jamiate Islami Mujahideen, loyal to President Prof Burhanuddin Rabbani.

The reports state that due to uncertain situation, the armed guards have established their own rules. They are levelling charges against their opponents and awarding punishments and penalties. Even the low-rank Mujahideen Commanders have established prisons and are keeping their opponents away from their relatives for months demanding heavy amount in ransom.

\section{Rs. 23m British aid for Kabul}

The British government is to give a further $£ 500,000$ (Rs. 23 million) in response to the contin. uing emergency situation in Kabul. The money will be used to help rehabilitate water supplies and to remove solid waste from the city.

According to a press release, $£ 300,000$ will be allocated to Care International for their ongoing programme of humanitarian relief and $£ 200,000$ will be given to UNCHS (Habitat) for its programmes in Kabul.

This brings British financial support for humanitarian aid to Afghanistan to E3.3 million (more than Rs. 150 million) since January 1994.

\section{APR 1994 NATION} ERONTIER POST 


\section{$\mathrm{UN}, \mathrm{OIC}$ to work for truce in Afghanistan}

ISLAMABAD, April 7: The United Nations and the organisation of Islamic Conference have agreed to launch joint efforts to broker ceasefire and an overall political settlement in Afghanis. tan.

Talking to newsmen at Islamabad airport before depar. ture for Jeddah, the special representative OIC, Secretary General, Mr Ibrahim Saleh Al Bakr, said he had met UN special envoy on Afghanistan, Mehmood Mestiri.

He said Mestiri would visit OIC headquarters after finishing his tour to the region.

"Permanent and unconditional ceasefire," is a pre-requisite to peace and order in Afghanistan, he said and added that all Afghan leaders, including President Burhanuddin Rabbani, had accepted it but Prime Minister Gulbuddin Hekmatyar was adamant on Rabbani's resignation.

He said OIC intended to open its office in Kabul once Afghans agreed to a permanent ceasefire. After that "we will initiate efforts fui a solitical dialogue to discuss formation of an interim govern. ment, composition of the Shura and holding of elections.

He said OIC would soon open a liaison office in Islamabad.-APP

\section{APR 1994}

\section{DAWN}




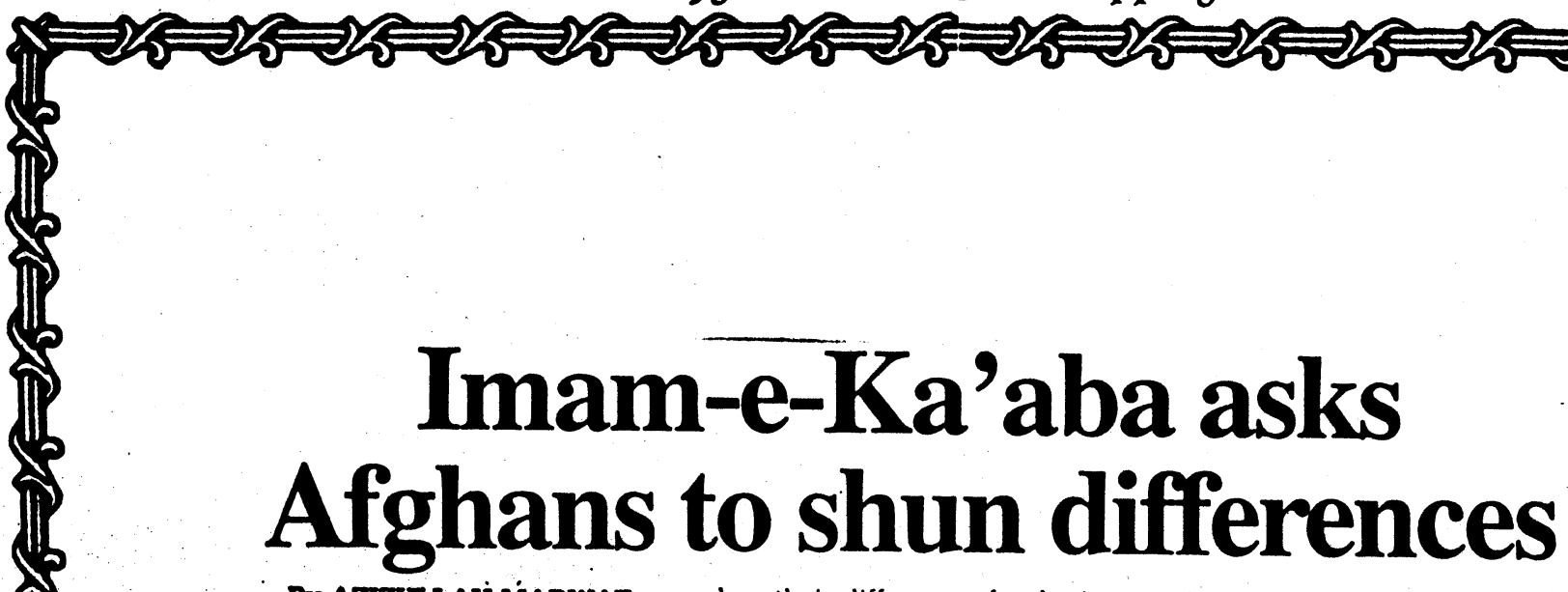

By ATTZUTLLAH MARWAT

Imam Ka'aba Muhammad Abdullah Subayyal has urged the need for peace and unity in the world and stressed the Afghan leaders to resolve their differences for a strong Afghanistan.

He was addressing the second international conference of Muslim scholars of Afghan issue at a local hotel on Wednesday.

The religious leaders of Pakistan, Afghanistan, Saudi Arabia, Malaysia, Jordan, Iraq, Bangladesh; Sudan and Tajikistan participated in the conference.

The conference was organised for searching a viable political solution to the ongoing war in Afghanistan.

The Afghan leaders, including Maulvi Muhammad Younas Khalis of his own faction of Hizb-i-Islami and Maulvi Muhammad Nabi Muhammadi of Harkat-i-Inqilab-iIslami participated in the conference while other Afghan parties were represented by their deputies and senior members.

Qazi Amin Waqad, deputy chief of Hizb-I-Islami (Hikmatyar) chief justice Afghanistan. Muhammad Shah Fazli of Harkat1-Inqilab-1-Islami, Zabihullah Mujadedi of National Liberation Front of Afghanistan were among the other prominent leaders.

Imam Ka'aba in his address said that the Afghan jehad was fully backed by the Muslim world against the Soviet aggression but the recent internal fighting between different Afghan factions created disparity among the Muslims.

He asked the Muslims to follow the teachings of Islam and said that Quran and Sunnah were the guidelines to lead a successful life.

He stressed the Muslims to shun their differences for the integrity and solidarity of the Muslim world.

The other speakers, including Dr Ibrahim Bakar, assistant general secretary, OIC, Sheikh Abdullah Al-Aqeel, assistant general secretary Rabita Alam-e-Islam, Maulana Abul Kalam of Bangladesh and chief organiser of the conference Malik Abdur Rauf also addressed the conference and urged the need for a united and strong Afghanistan.

Maulana Abul Kalam Azad of Bangladesh said that people of Bangladesh also took part in the Afghan jehad against the communist forces of former USSR and sacrificed their lives. But now whatever was going on in Afghanistan had agonised the Muslims all over the globe.

The internal clashes killed a number of innocent Afghans and destroyed the whole country in the race to grab power. We cannot face the people in Bangladesh to whom we had been preaching for the jehad in Afghanistan because the people were now questioning as the whether it was jehad", he questioned.

He said all the religious leaders should struggle for a permanent ceasefire and restoration of tranquility in the war torn country otherwise "we all will be responsible for this enormous destruction". .

The inaugural session of the conference started at 11 a.m. and continued for about two hours.

Due to mismanagement both the sessions of the conference began late.

On the conclusion of the second session an informal committee was formed which will discuss various aspects of the Afghan issue and present its report to the Ulema.
The organisers refused to divulge names of the committee members by saying that it would be announced after the second working session on Thursday.

According to a reports the committee comprised of about 20 to 25 persons including leaders of Afghanistan, religious leaders of Pakistan. Saudi Arabia and other countries who conducted a close door meeting Wednesday.

Sources said that Maulvi Muhammad Younas Khalis of Hizb-i-Islami who was chairing the working session will lead the committee.

The spokesman of the conference in a briefing said that it was decided some two months back to organise a conference on Afghanistan in which all the Afghan parties would be invited, besides religious leaders of the Islamic world, especially from Pakistan.

The purpose of the conference is to hold a permanent ceasefire in Afghanistan and secondly to find out such a political solution of the Afghan issue that could be acceptable to all the Afghan factions.

Mutahidda Ulema Council was formed to organise the conference with the coordination of Rabita Alam-e-Islami.

The religious leaders of Pakistan who attended the conference included Maulana Samiul Haq of JUI(S). Maulana Gohar Rahman of JI, Maulana Abdul Rahim Chitrali, Maulana Hasan Jan, Arif Hussain Shah, MPA Punjab, Mufti Rafi Usmani, Zafar Ali Nomani, Asad Thanvi of JUI. Murad Ali Shah of JI and senator Abdur Rahman.

The ambassadors of Saudi Arabia, Muhammad Yousaf and that Sudan, and Yaman were also present. 


\section{From Our Correspondent}

PESHAWAR - World level-Islamic organisations and forces once again on Wednesday assembled in second international Muslim scholars conference on Afghan issue here in Peshawar to save fruit of Afghan Jehad by assembling Mujahideen leaders to resolve their internal differences and adopt a unanimous stand to form an Islamic government in Afghanistan.

The two days international conference being held in Peshawar at the time, when a high level delegation of United Nations, headed by Mehmood Mestiri, to build up concensus among the Afghan leaders to find out on amicable and durable settlement to the conflict through peaceful ways. The speakers, however, said nothing about the efforts of United Nations for resolving the Afghan conflict.

The second international Muslim scholars conference being held under the auspices of Mutahida Ulema Council with the collaboration of Mautamer Alam-i-Islam and other Muslim organisations. The conference is being attended by Ulema from various parts of the world included Saudi Arabia, "Bangladesh, Afghanistan, Iran, Pakistan and other countries. It was witnessed that activists of the world level organisation are known for Akhwan-ulMuslimeen and were too much active during the proceedings of the conference.

Apart from Muslim scholars, the conference was attended by a large number of religious-cum-political leaders of Afghanistan and Pakistan. Prominent among them were Maulvi Mohammad Nabi Mohammadi, Maulvi Mohammad Younas Khalis, Qazi Mohammad Amin Waqad, Dr Zabihullah Mujaddedi, Maulvi Mohammad Shah Nawab, Mohammad Saleem, Haji Mangal Hussain and others. From Pakistan the conference was attended by Senator Maulana Sami-ul-Haq. Maulana Abdul Rahim Chitrali, MNA, former MNA Maulana Hassan Jan, Dr. Murad Ali Shah of Jamaat-i-Islami, Maulana Gohar Rehman, Prof. Mohammad lbrahim Khan and others.

On the first day the conference was addressed by Imam-i-Kaaba Sheikh Mohammad bin Abdullah Sobail, Amin Irabhim Bakar Sheikh Abdul Malik, Maulvi Abdul Rauf, Maulvi Ahmad Gul, Abul Kalam Mohammad Yousaf and others. Most of the speakers focused their views on ongoing bloodshed and destruction in Afghanistan which they termed harmful to the interest of the Islamic organisations all over the country. They stressed upon the Mujahideen leaders to bring an end to ongoing fighting and adopt a joint strategy to form an Islamic government in their motherland.

Sheikh Mohammad Bin Abdullah Sobail in his address termed the ongoing fighting danager to the Islamic world. He said that rival Afghan Jehadic leaders should stop fighting and resolve their differences in the light of Sharia. He also called upon the Jehadic leaders to accommodate the proposals each others for coalition government.

He said that responsibility rests with Afghan Mujahideen leaders accept their duties and resolve their differences.

Sheikh Abdullah further said that Afghans are their Muslim brothers and they did not want bloodshed and destruction in Afghanistan. He said that like other Muslims countries Saudi people will also extend due cooperation and assistance to those who are struggling for restoration of peace. He called upon the Mujahideen leaders to let the mediators to help peace in that country.

\section{NATION}

07 APR 1994 
A convoy of five trailers, containing relief consignment donated by the Islamic Republic of Iran. for the battered and displaced Afghan refugees left Peshawar for Kabul via Jalalabad on Wednesday, says a press release of consulate general of Iran in Peshawar, reports APP.

The relief goods which included 300 tents, 2500 blankets and 1200 bags of flour were escorted to Jalalabad by Mohsen Rouhi Sefat, consul general of the Islamic Republic of Iran at Peshawar which will be distributed among the war stricken Kabulites by the Iranian embassy at Kabul.

It is pertinent to mention that earlier a large quantity of relief goods were distributed among the Afghan refugees at two main refugees camps in Peshawar by the Iranian consul general.

The despatch on Wednesday of the relief items will help in ameliorating the sufferings of starved population of Kabul to some ex. tent. The Iranian consul general have assured some more humanitarian relief which was in the pipeline.

While expressing optimism about the success of the UN peace mission, recently in Kabul. in striking a permanent ceasefire deal among the belligerent Afghan groups, the Iranian diplomat reiterated his government's

stand of non-interference in the internal affairs of his neighbouring country. He also assured to keep on helping the displaced Afghan people on humanitarian grounds.

\section{Afghan relief}

An Iranian convoy carrying relief goods left here Wednesday for Kabul, the Iranian consulate general said in Peshawar, reports AFP.

The convoy is ferrying 2,500 blankets, 300 tents and 1,200 bags of flour for distribution among war-stricken poople in the Afghan capital, the mission said in a statement.

The consultate did not say whether a safe passage for the five-trailer convoy had been assured by warring Afghan factions.

A UN relief convoy was held up for days near Kabul recently.
Iranian relief

consignment dispatched to Kabul

PESHAWAR (APP) - A convoy of five trailers, containing relief consignment donated by the Islamic Republic of Iran, for the battered and displaced Afghan Refugees left Peshawar for Kabul via Jalalabad today, says a Press release of consulate general of Iran in Peshawar.

The relief goods which included 300 tents, 2500 Blankets and 1200 bags of flour were escorted to Jalalabad by MrMohsen Rouhi Sefat, Consul General of the Islamic Republic of Iran at Peshawar which will be distributed among the war stricken Kabulites by the Iranian Embassy at Kabul.

It is pertinent to mention that earlier a large quantity of relief goods were distributed among the Afghan refugees at two main refugees camps in Peshawar by the Iranian Consul General.

The despatch on Wednesday of the relief items will help in ameliorating the sufferings of starved population of Kabul to some extent. Mohsen Rouhi Sefat, Iranian Consul General have assured some more humanitarian relief which was in the pipeline.

While expressing optimism about the success of the UN peace mission, recently in Kabul, in striking a permanent ceasefire deal among the belligerent Afghan groups, the Iranian Diplomat reiterated his government's stand of non-interference in the internal affairs of his neighbouring country. He also assured to keep on helping the displaced Afghan people on humanitarian grounds.

\section{NATION}

07 APR 1994

\section{APR 1994 NATION Libyan team to visit Afghanistan}

From Our Correspondent

PESHAWAR - After the failure of Ulema delegation, a nine-member team of scholars from Libya is desirous to early visit Kabul. The team will convince the rival Afghan leaders for an early ceasefire to resolve the conflict through peaceful and political ways

The nine-member team of Dawa College of Libya, headed by $\mathrm{Mr}$ Mukhtar Ahmed Dera, arrived in Peshawar four days ago. The team has concluded its negotiations and talks with the leading Afghans in Peshawar and now wants to leave for Kabul.

Mr Mukhtar Ahmed Dera when contacted said that they have no formula or proposal for resolving the conflict but will frame its strategy after listening the views of leading Afghans. He states that Libyan team is desirous of an early restoration of peace in war devastated Afghanistan.

The Libyan team in the last three days held detailed meetings with a number of leading Afghan dignitaries. They included former President Prof Sibghatullah Mujaddedi, moderate Afghan leader Pir Syed Ahmed Gilani, Maulvi Mohammad Nabi Mohammadi and others. They also held meetings with representatives of Afghan President Prot Burhanuddin Rabbani, Prime Minister Gulbadin Hikmatyar and others. 


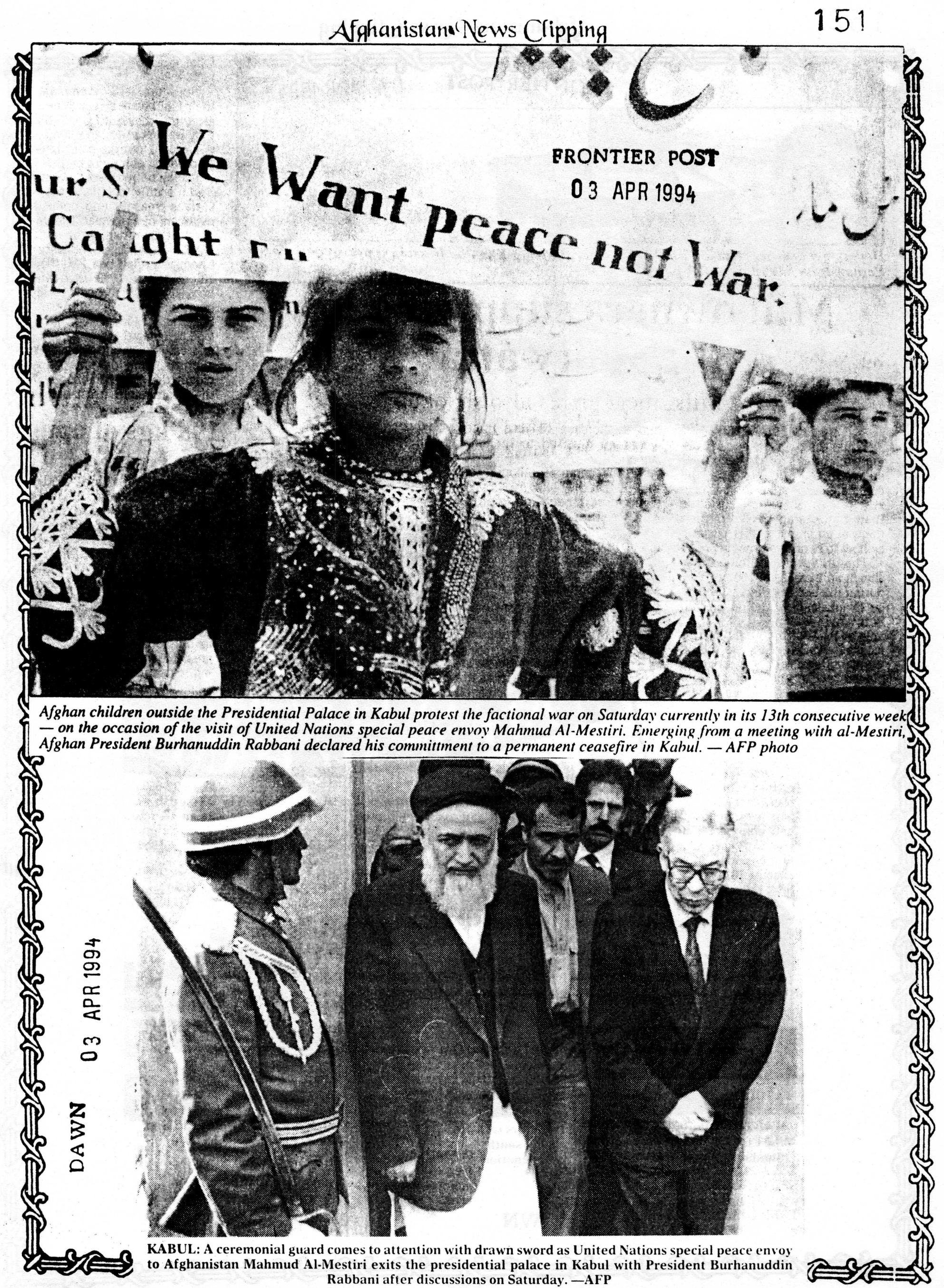




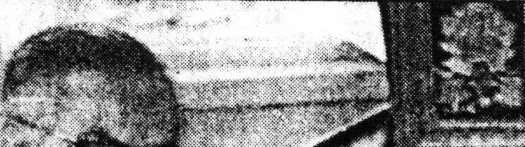

$x^{2}-303$
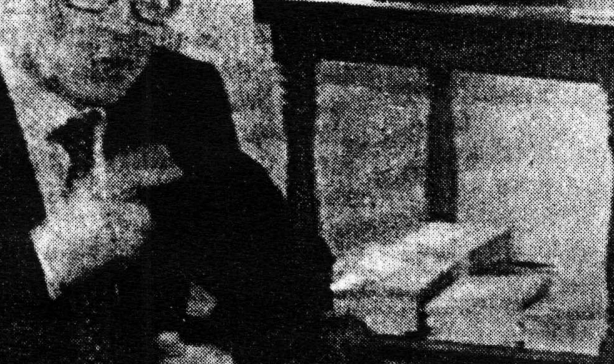

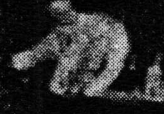
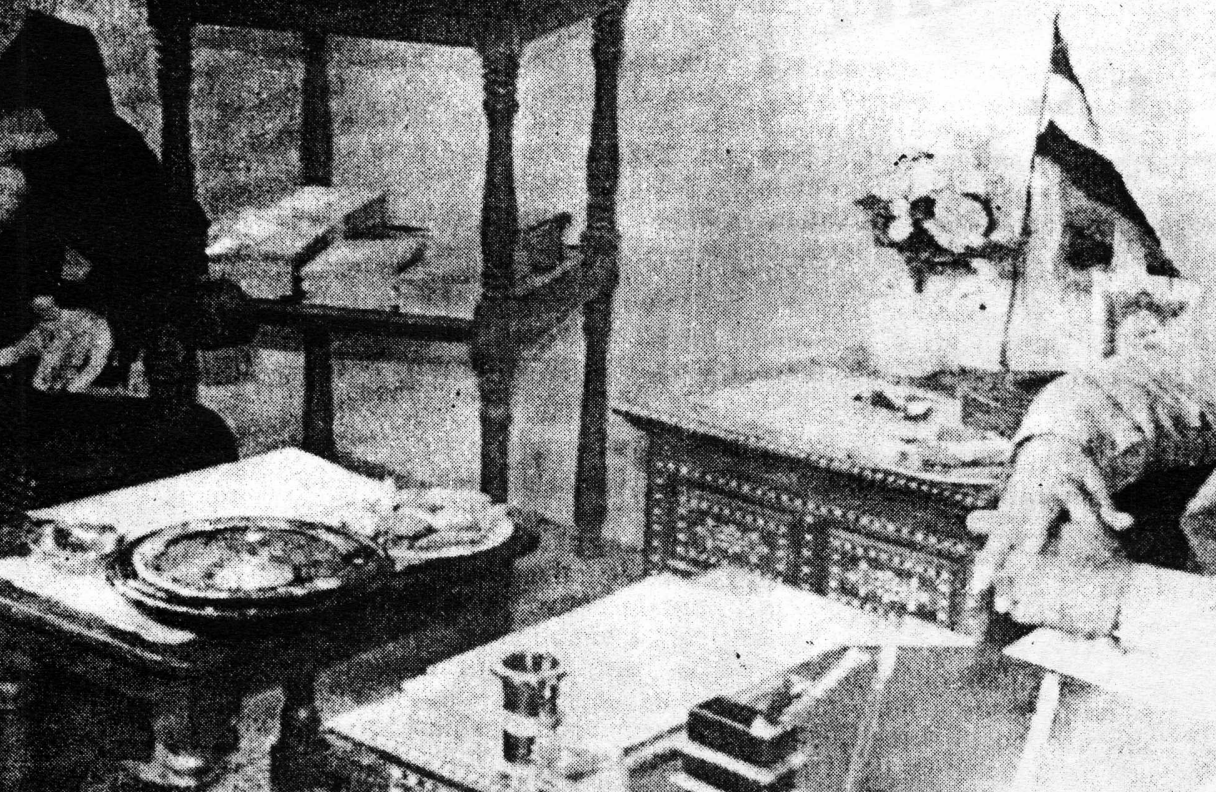

United Nations special peace envoy to Afghanistan Mahmud Mestiri $(L)$ in con
Hekmatyar at Charasiab some 25 kilometres southeast of Kabul. - AFP photo

䧑
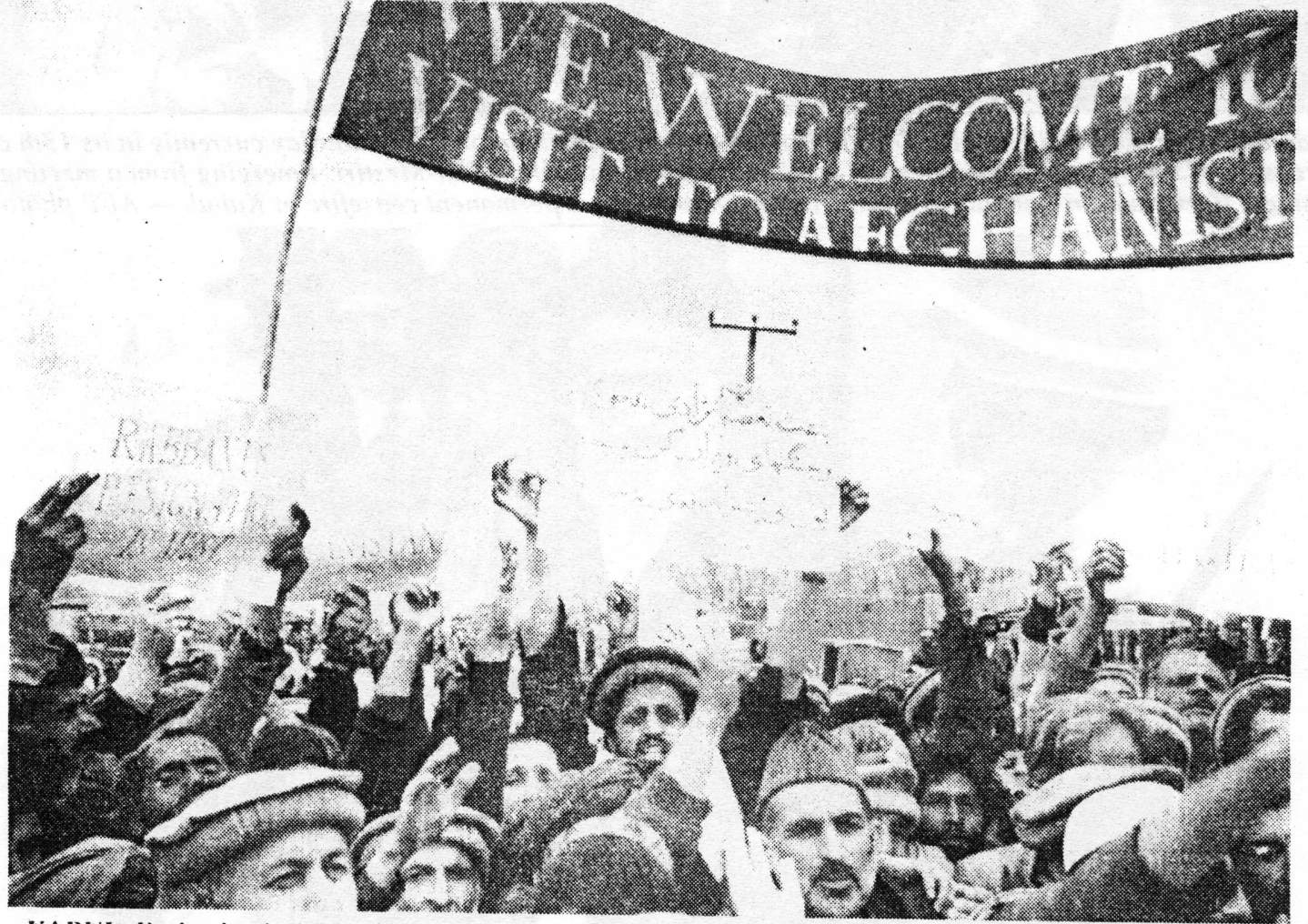

KABLL: Enthusiastic Afghan demonstrators welcome United Nations special envoy Mahmud Mestiri to the Charsyab headquarters (25 kilometres southeast of Kabul) of Prime Minister Gulbudin Hekmat yar on Sunday. Most placards called for the resignation of Hekmatyar's rival, President Burhanuddin Rabbani. - AFP 


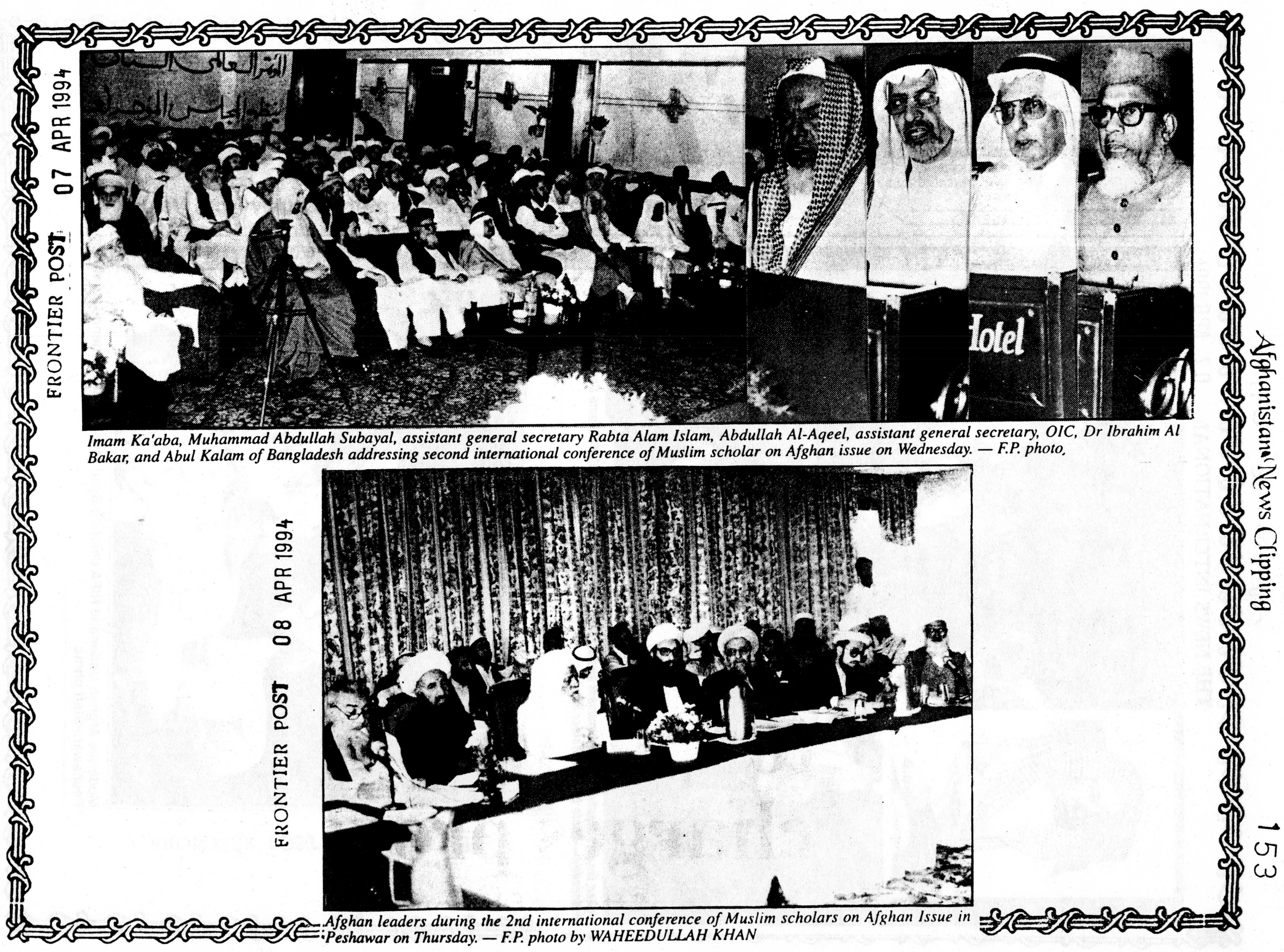




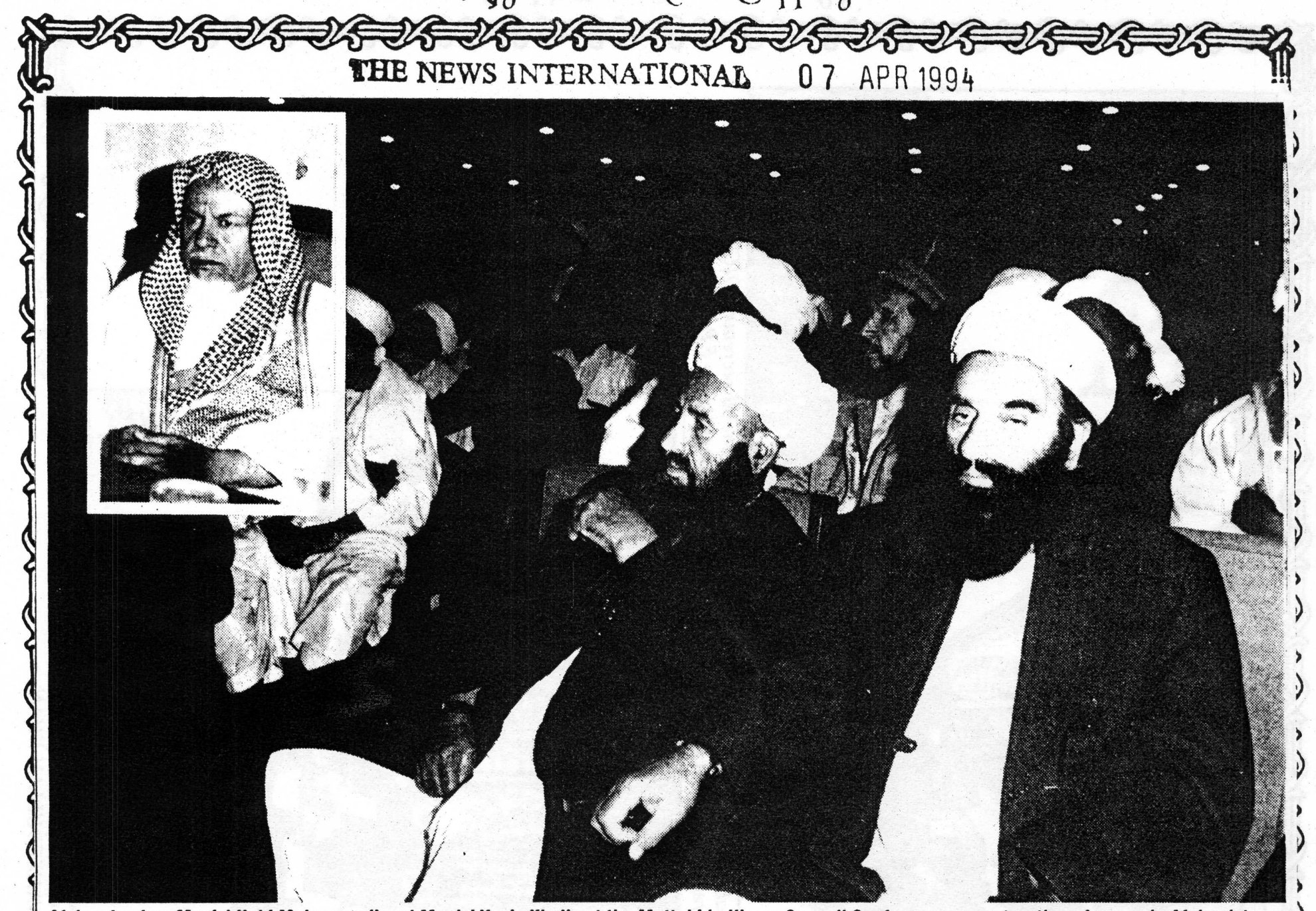

Afghan leaders Maulvi Mabi Mohammadi and Maulvi Yunis Khalis at the Muttahida Ulema Council Conference on restoration of peace in Afghanistan on ? Wednesday.-Photo by Syed Haider Shah

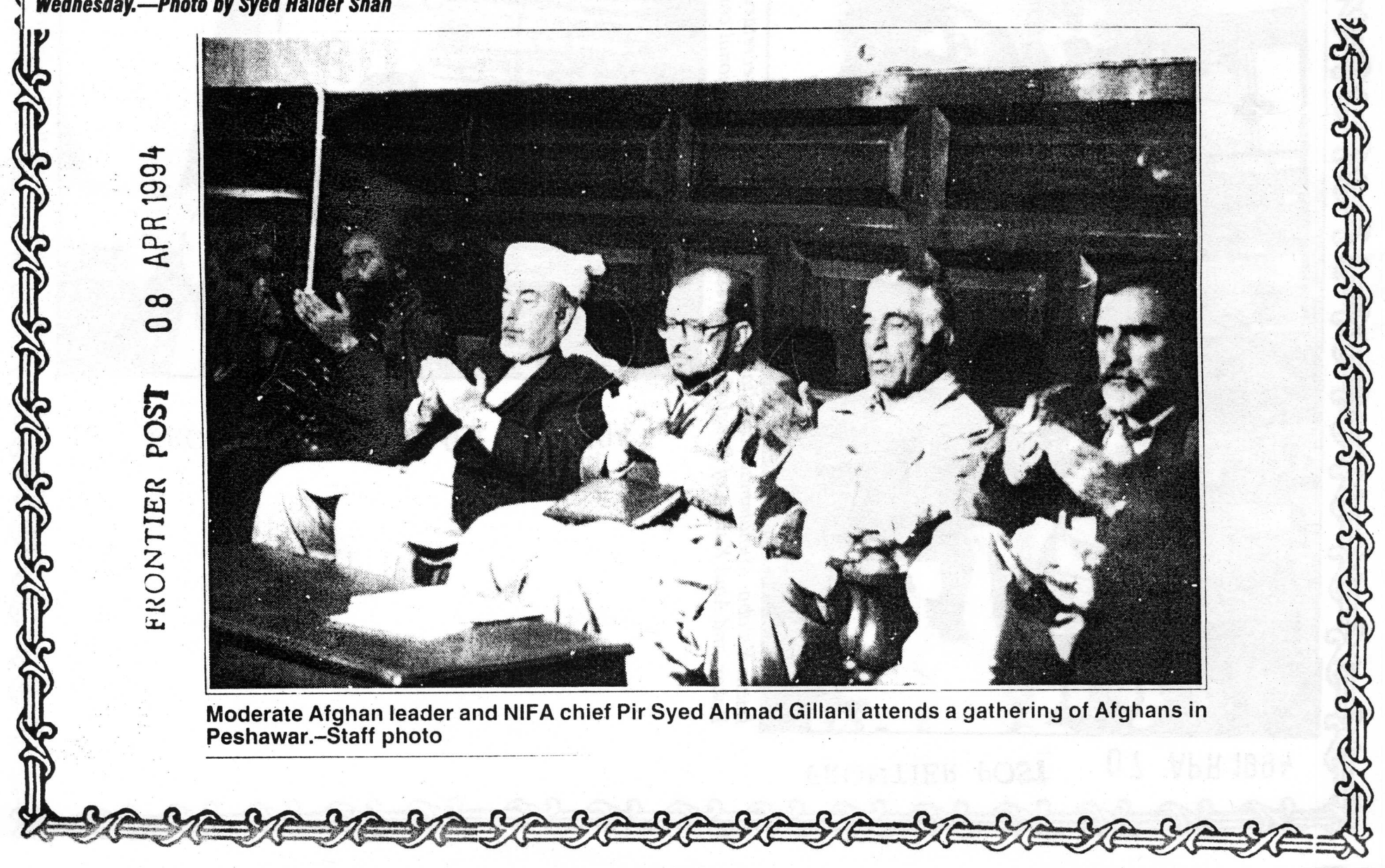




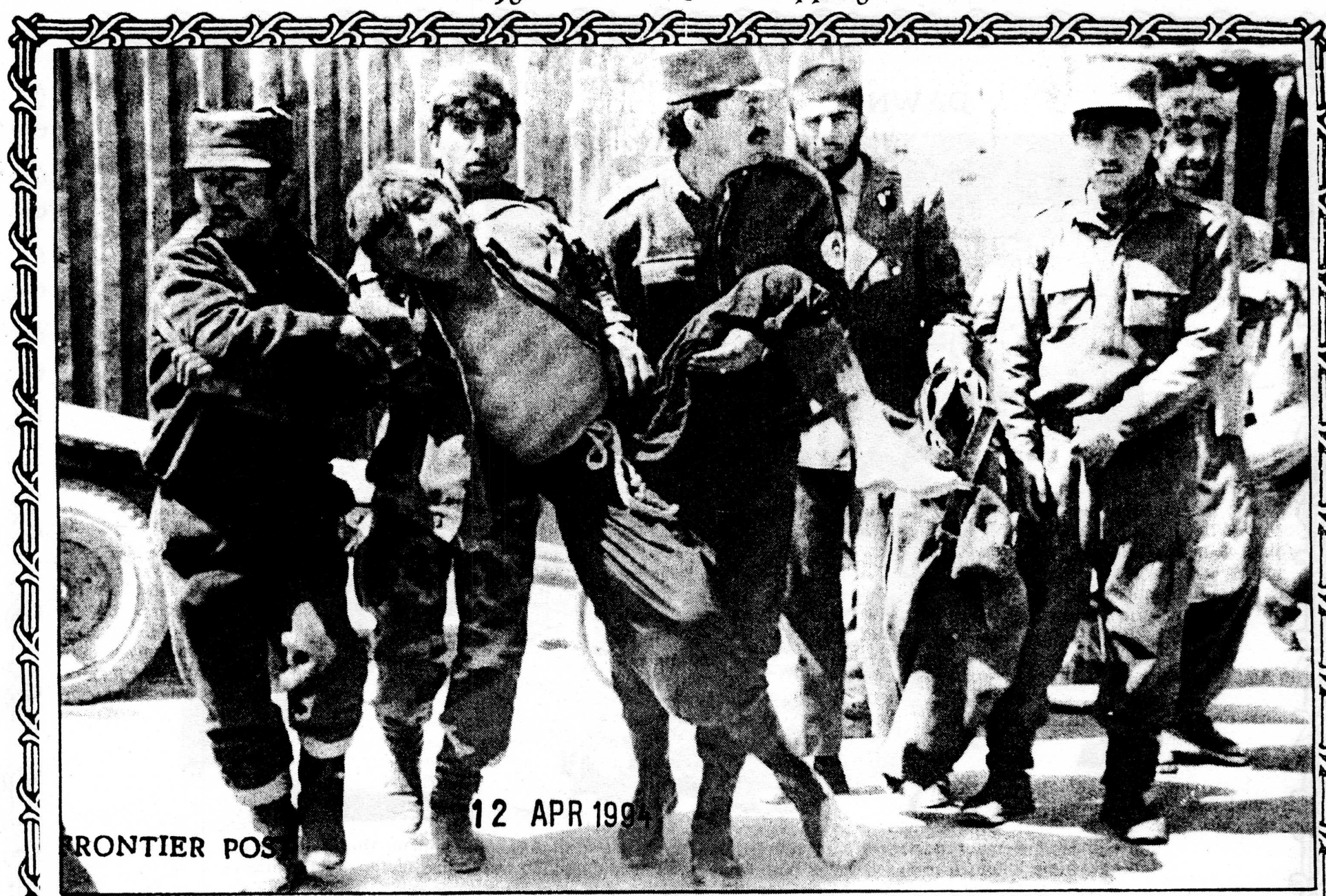

A Afghan man, wounded by bomb shrapnel in an attack by' je's of Uzbek warlord General Abdul Rashid Dustam, is carried by' security troops looking for a vehicle to carry him to hospital on Monday: Sixteen died and 144 wounded in a joint jet strike and artille'ry bombardment of Kabul.-AFP photo

(1)

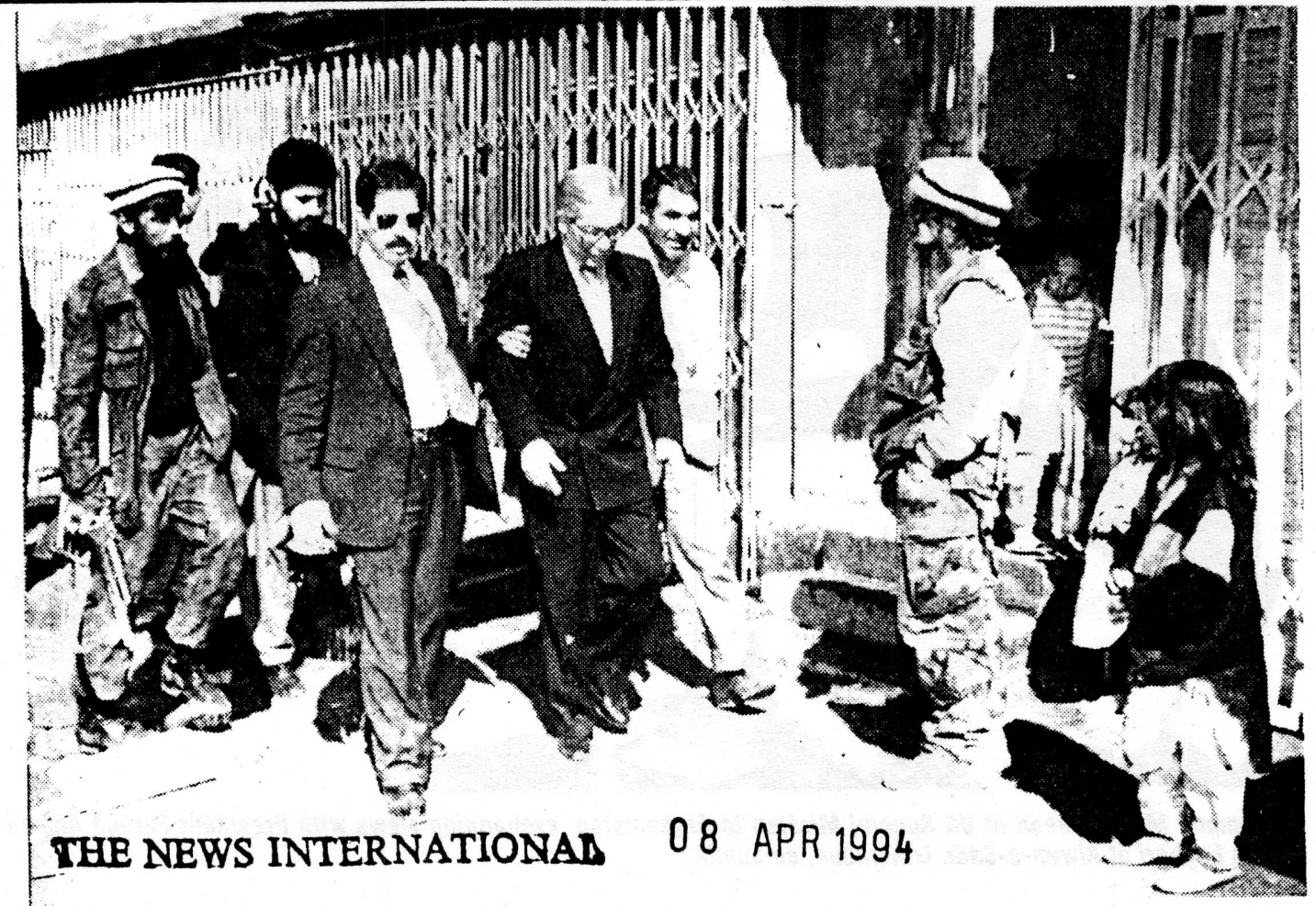

United Nations special peace envoy to Afghanistan Mohammad Mestiri, with Mujahedeen escort and UN entourage, is being assisted by his personal bodyguard along the footpath of Kabul's Chicken Street where Mestiri shopped for souvenirs before flying back to Pakistan.-AFP photo 
$156 \quad$ Afghanistana News Clipping

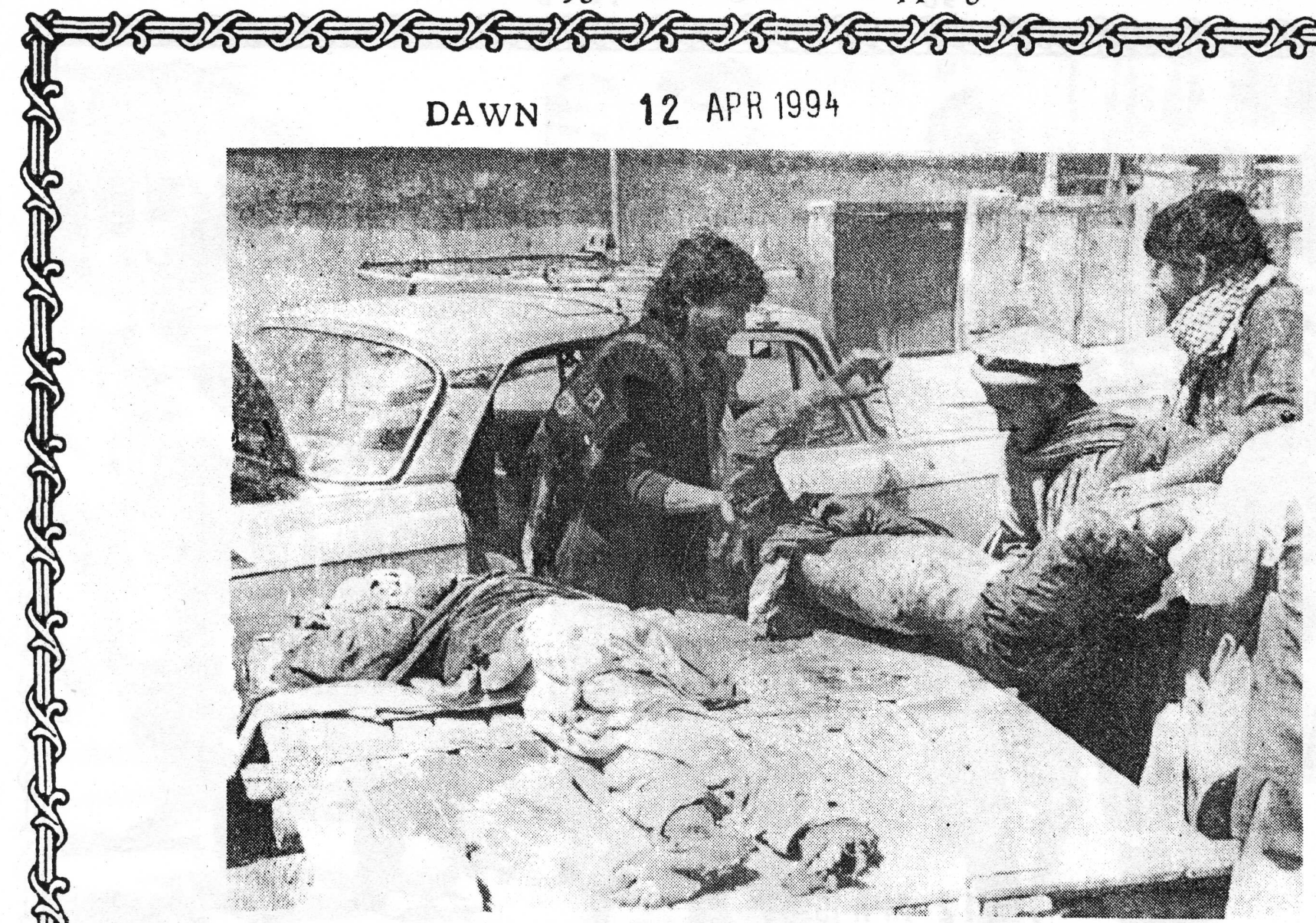

KABUL: Two victims of bombing by jets of Uzbek warlord Abdul Rashid Dostum on Monday morming: the wounded man is being hauled into the back seat of a commandeered taixi while the dead man goes into the boot.-AFP

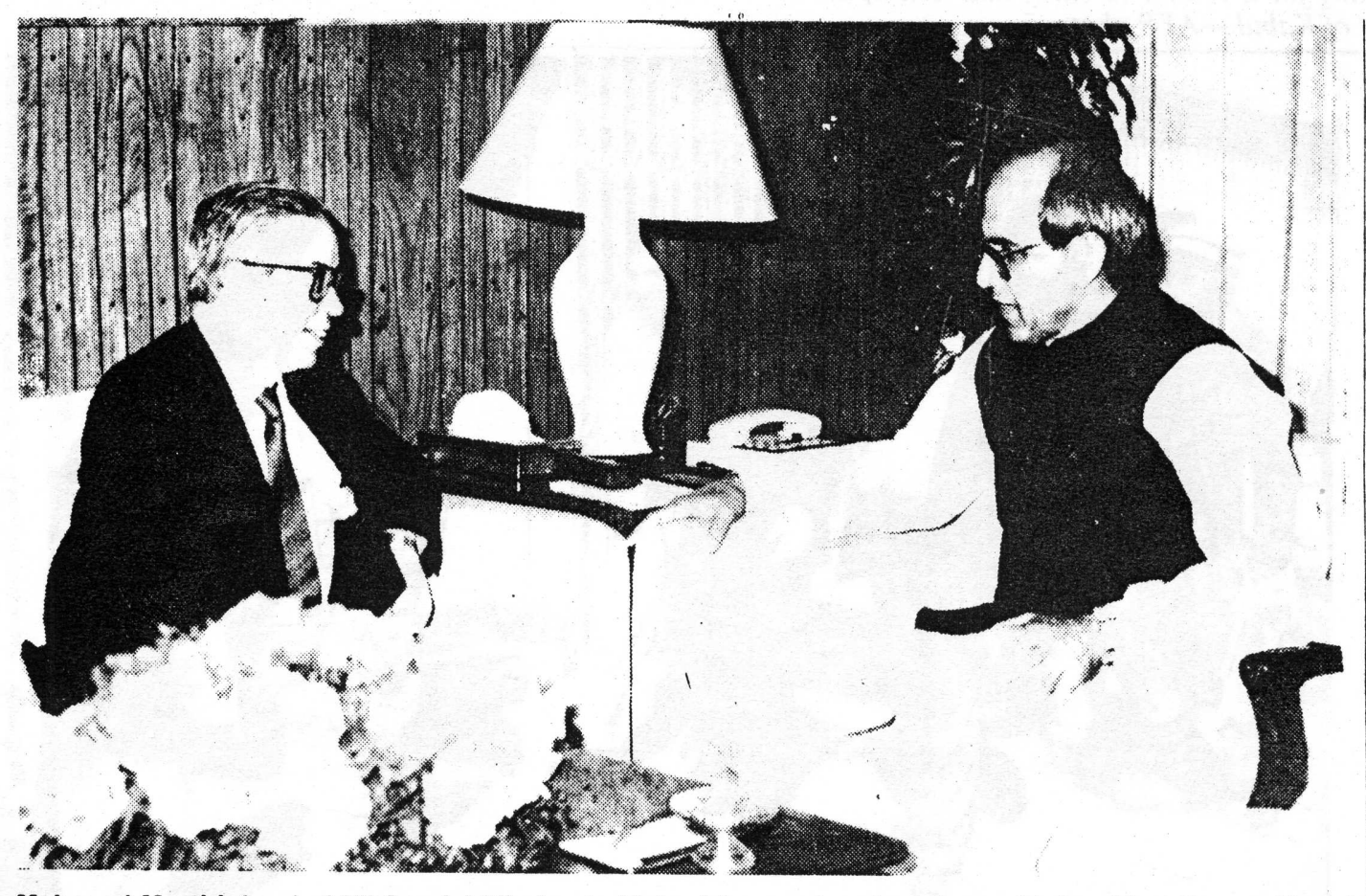

Mahmood Mestiri, head of UN Special Mission to Afghanistan, exchanging views with President Farooq Ahmed Khan Leghari at Aiwan-e-Sadr, Islamabad, on Sunday.

\section{THE NEWS INTERNATIONAD 11 APR 1994}




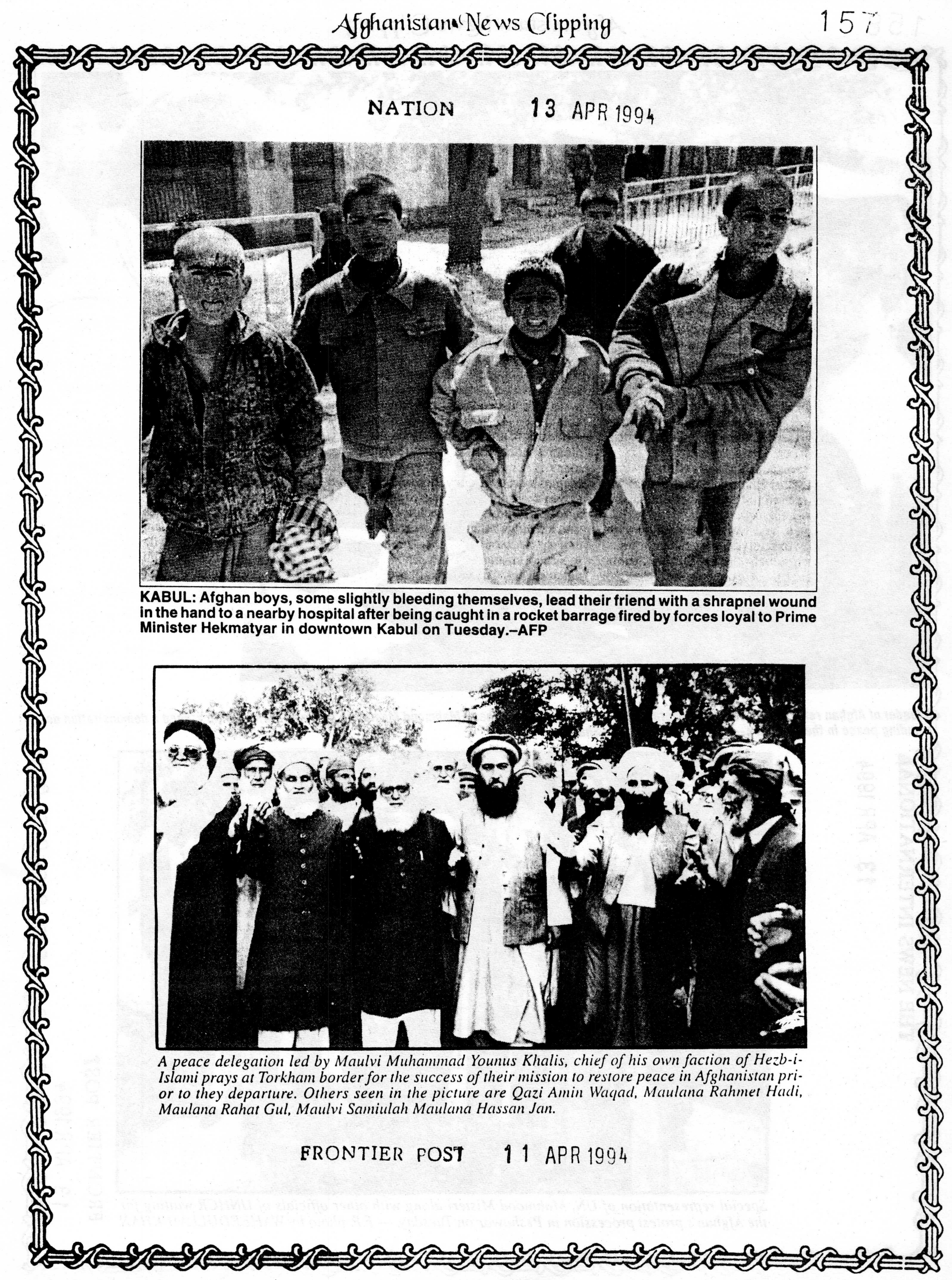




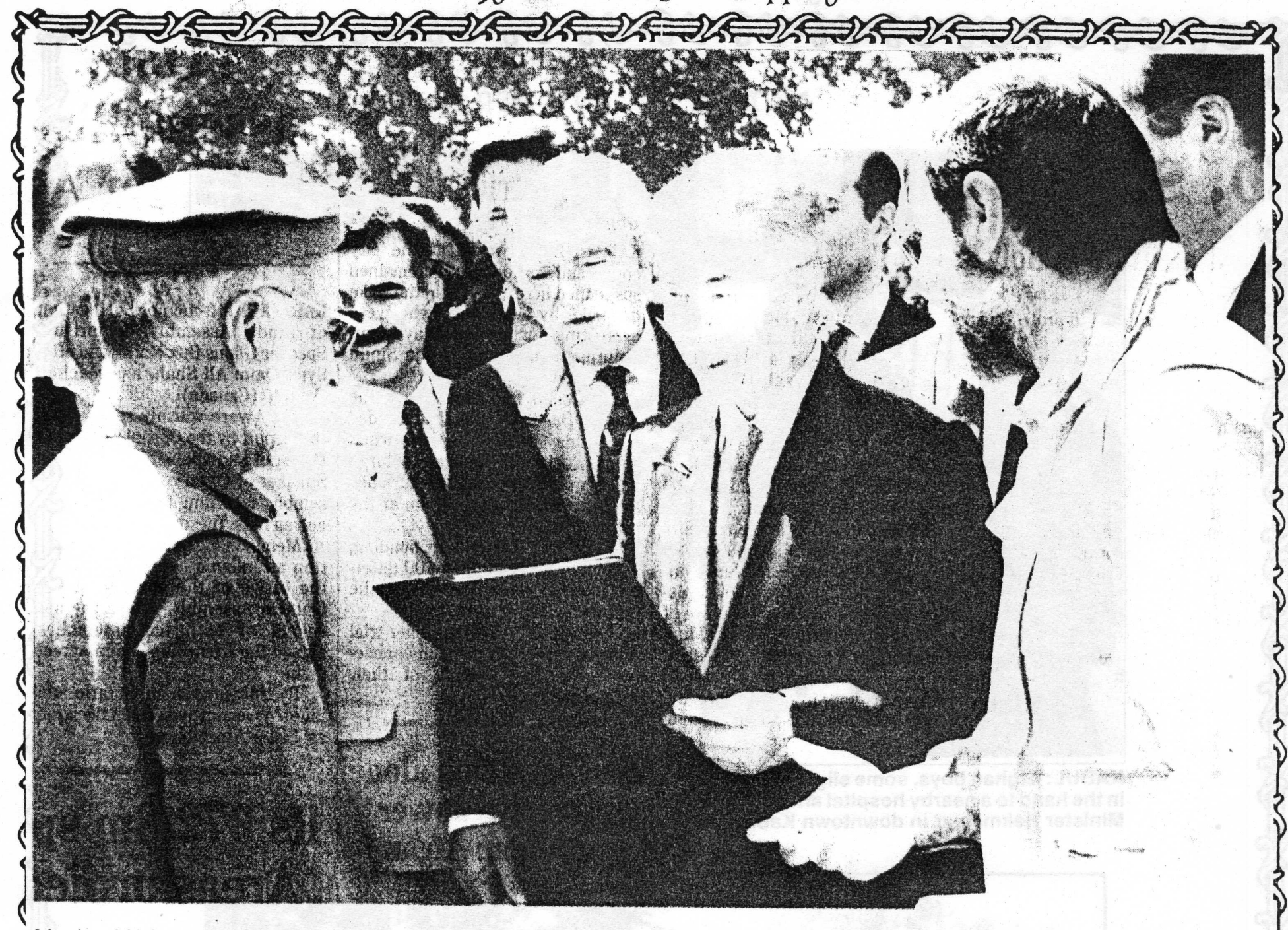

A leader of Afghan refugees presents a memorandum to UN peace mission head Mehmood Mesteri in Peshawar, who earlier staged a demonstration demanding peace in their country. - Photo by Syed Haider Shah
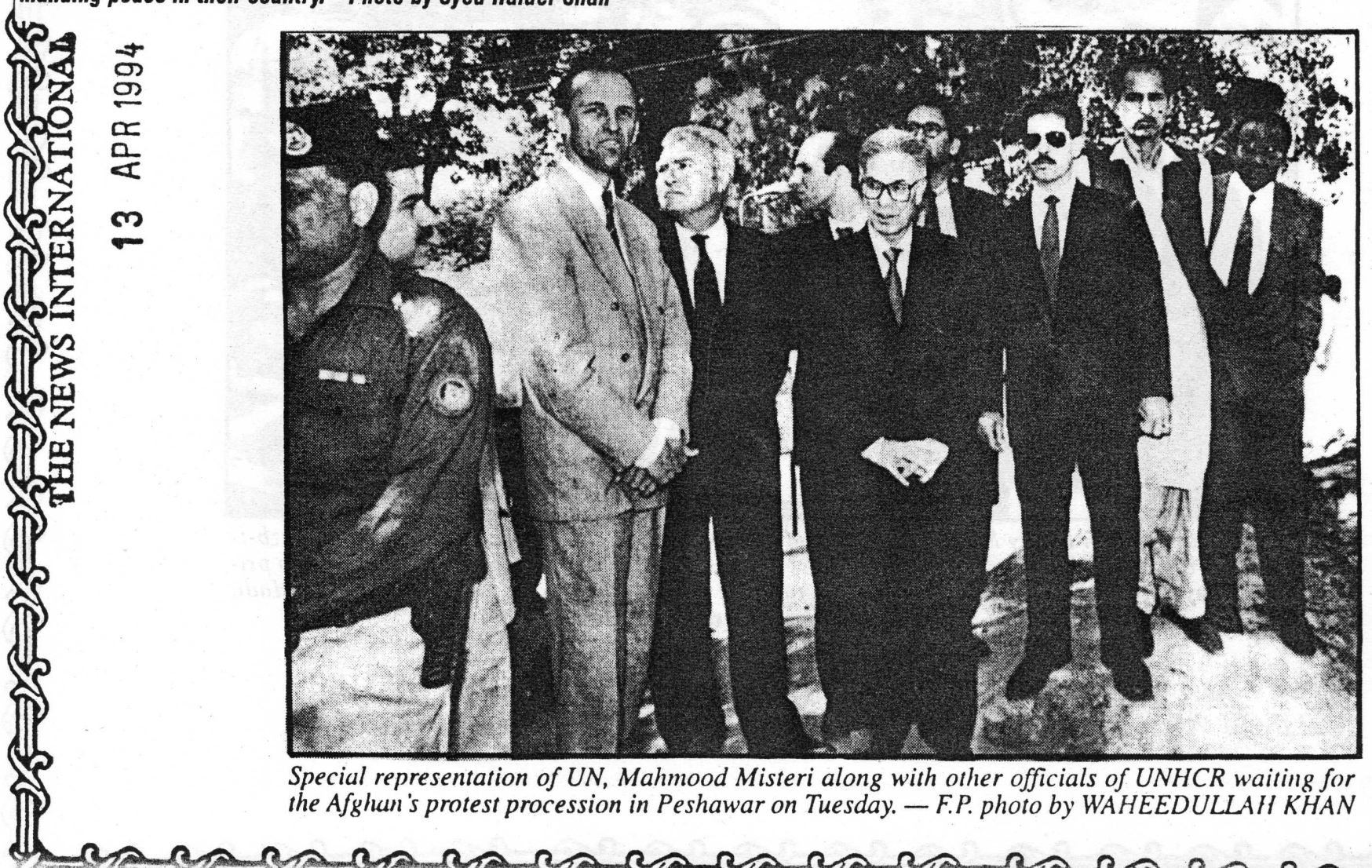

Special representation of UN, Mahmood Misteri along with other officials of UNHCR waiting for the Afghan's protest procession in Peshawar on Tuesday. - F.P. photo by WAHEEDULLAH KHAN 


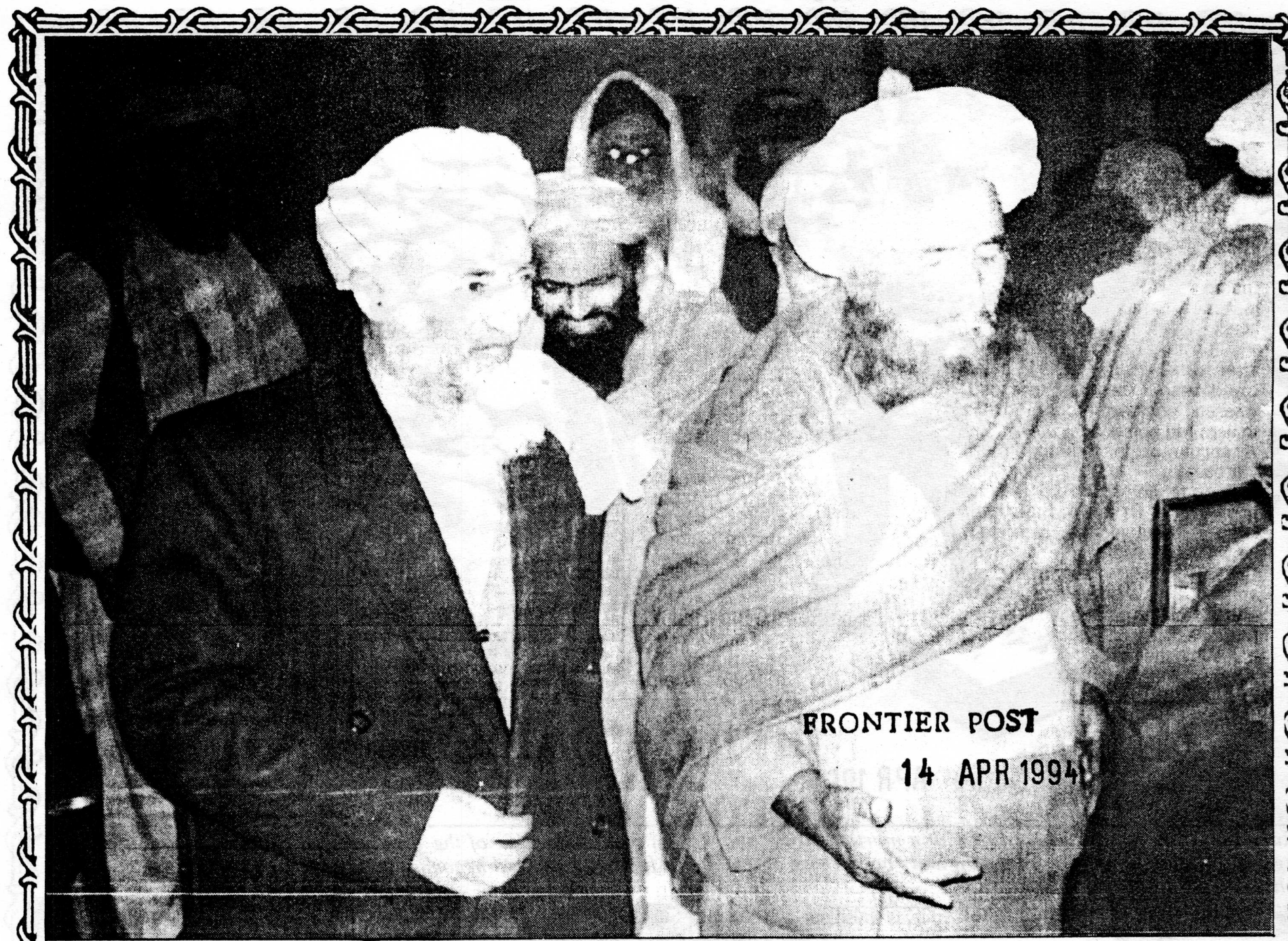

Afghan President Burhanuddin Rabbani ( $L$ ) escorts mujahideen faction

(1)

(1)
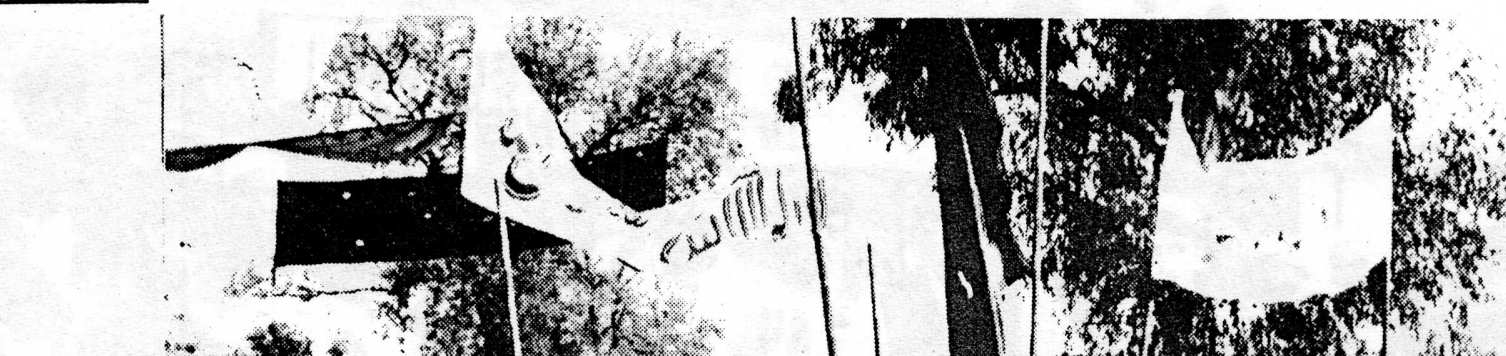


\section{0}

Afghanistana'News Clipping

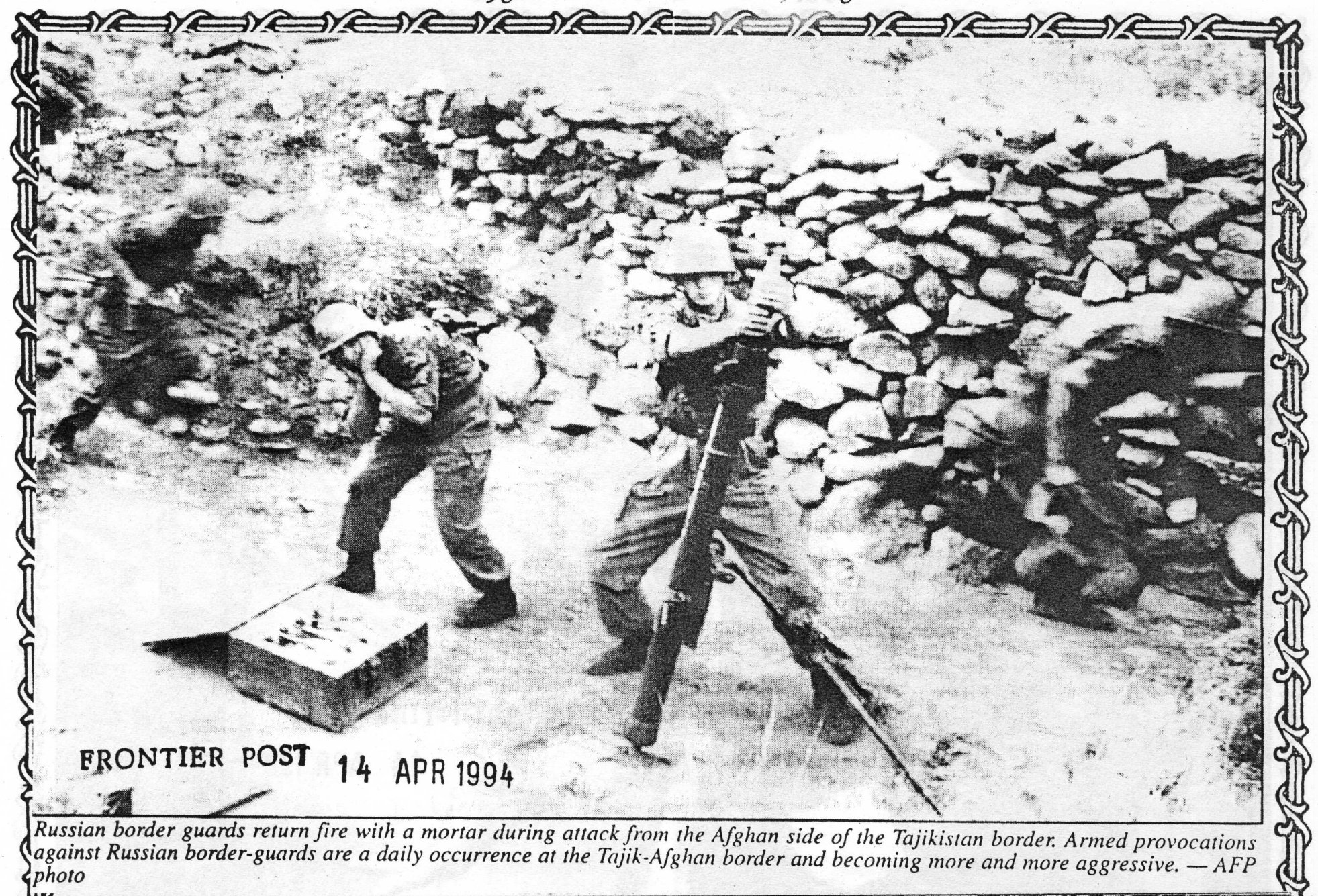

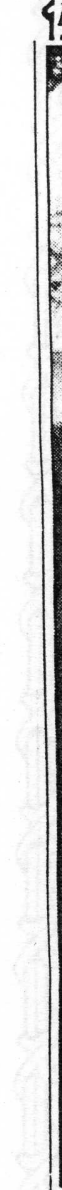

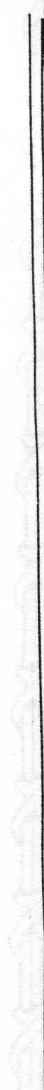


Afghanistana'News Clipping

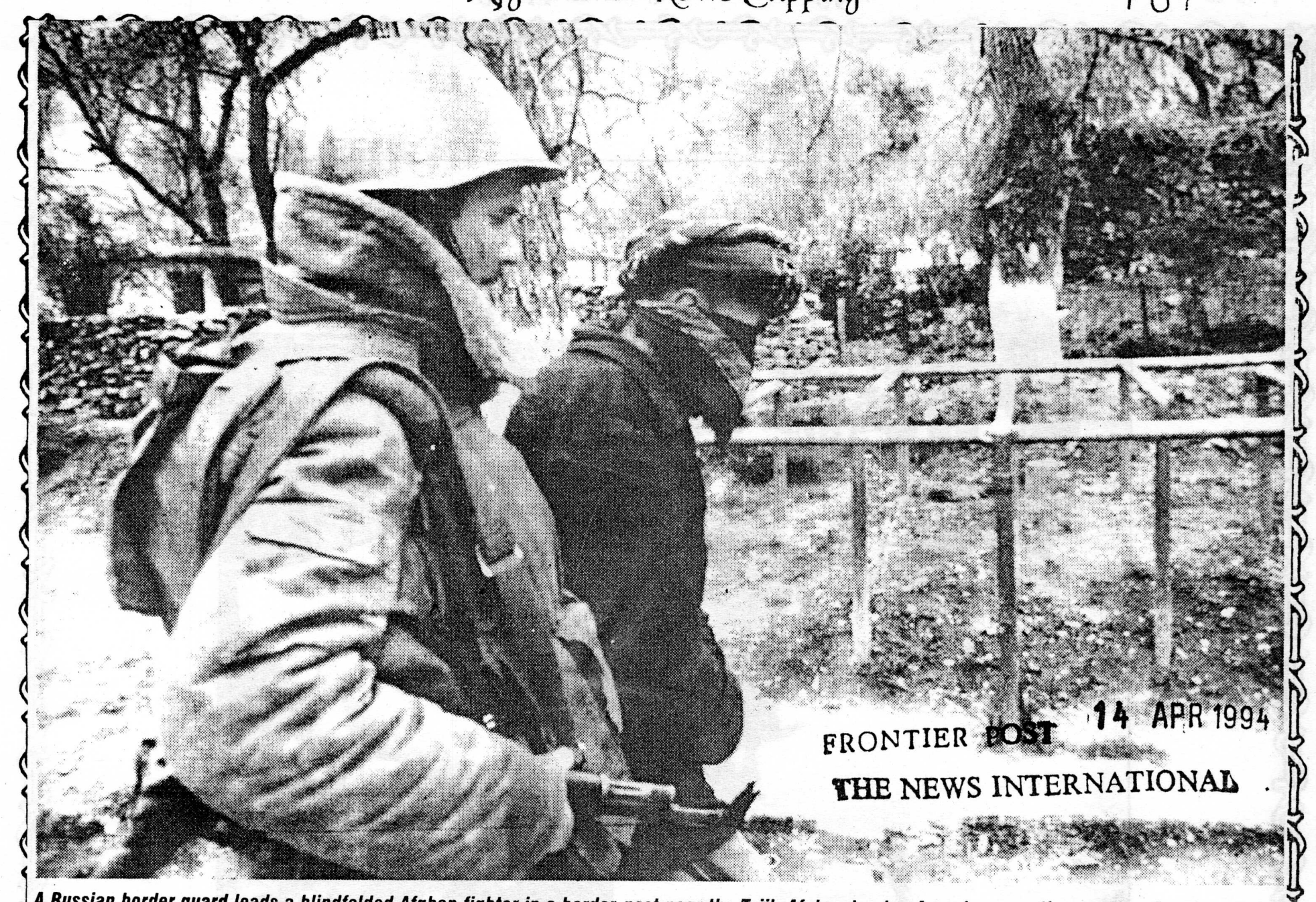

A Russian border guard leads a blindfolded Afghan fighter in a border-post near the Tajik-Afghan border. Armed provocations against Russian border guards continue on the Tajik-Afghan border where incidents are reported.-AFP photo

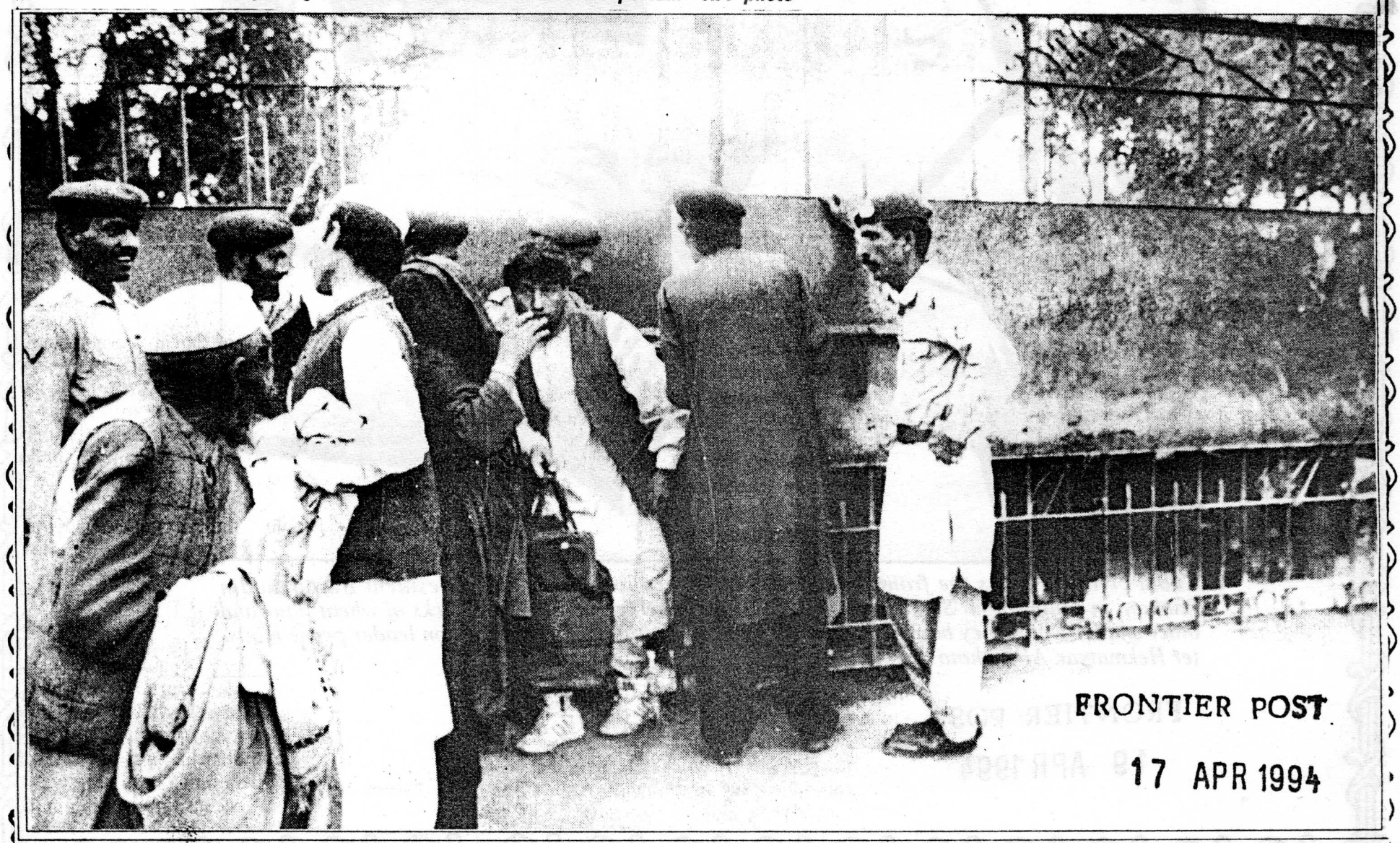




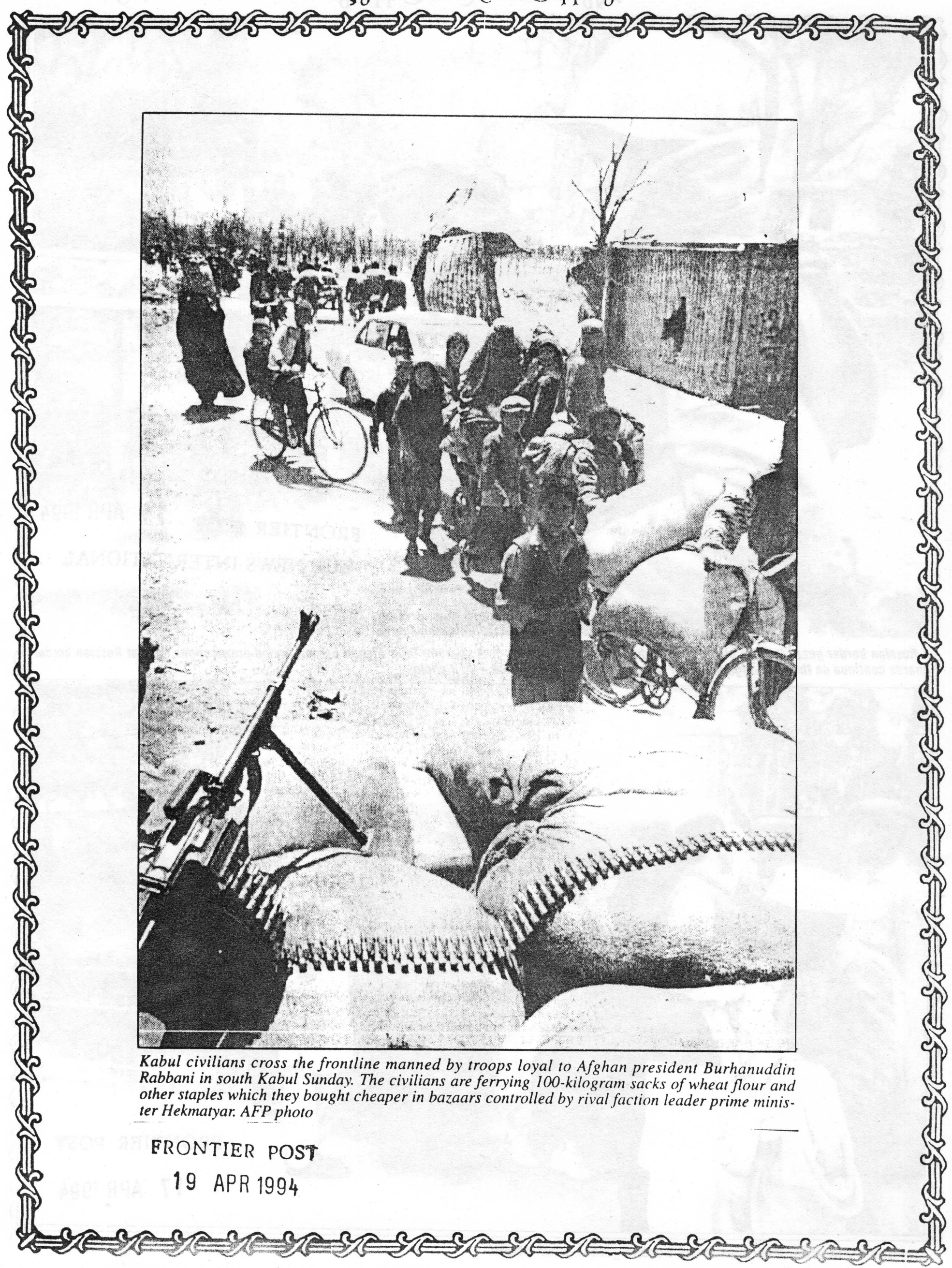




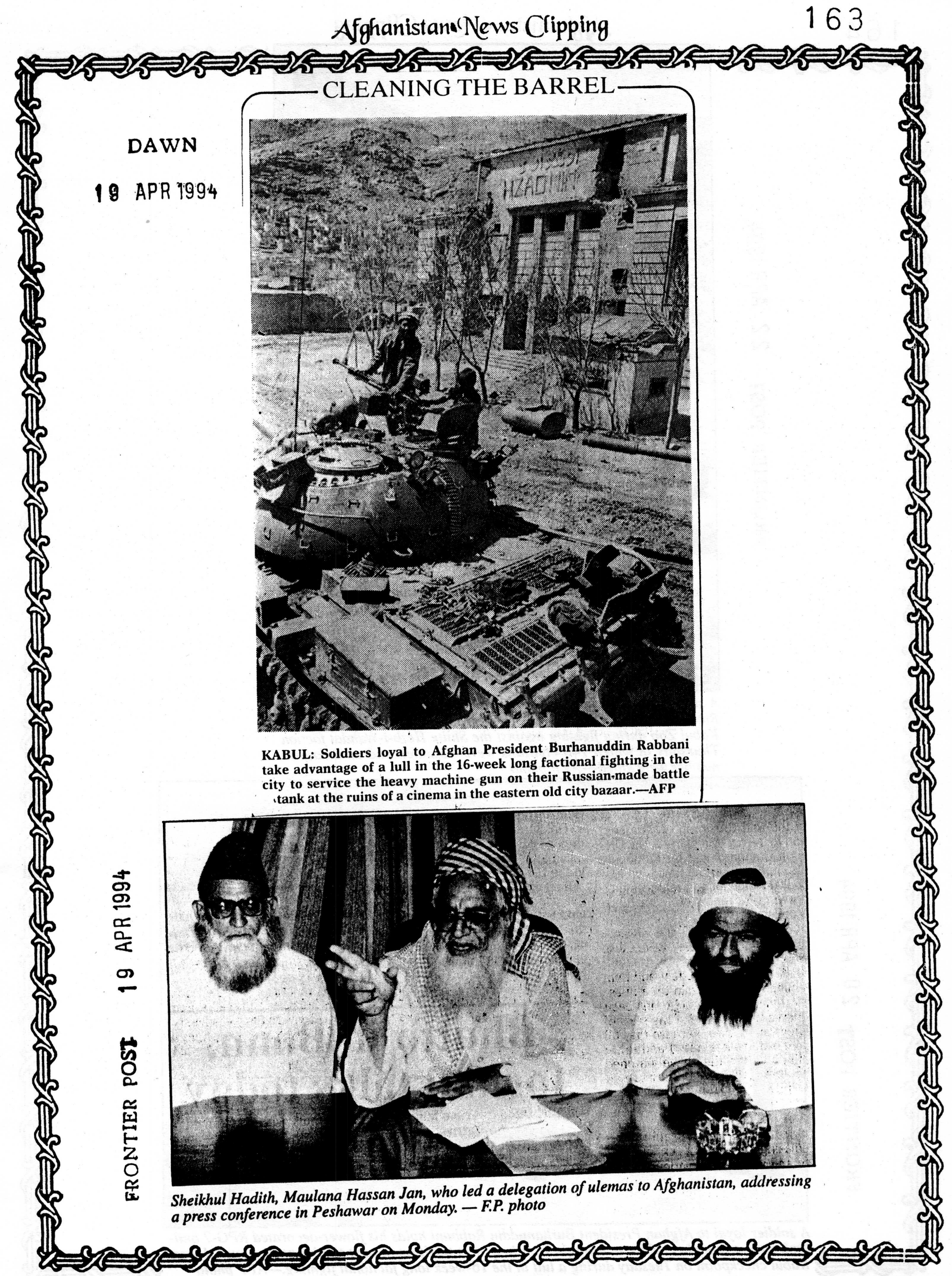



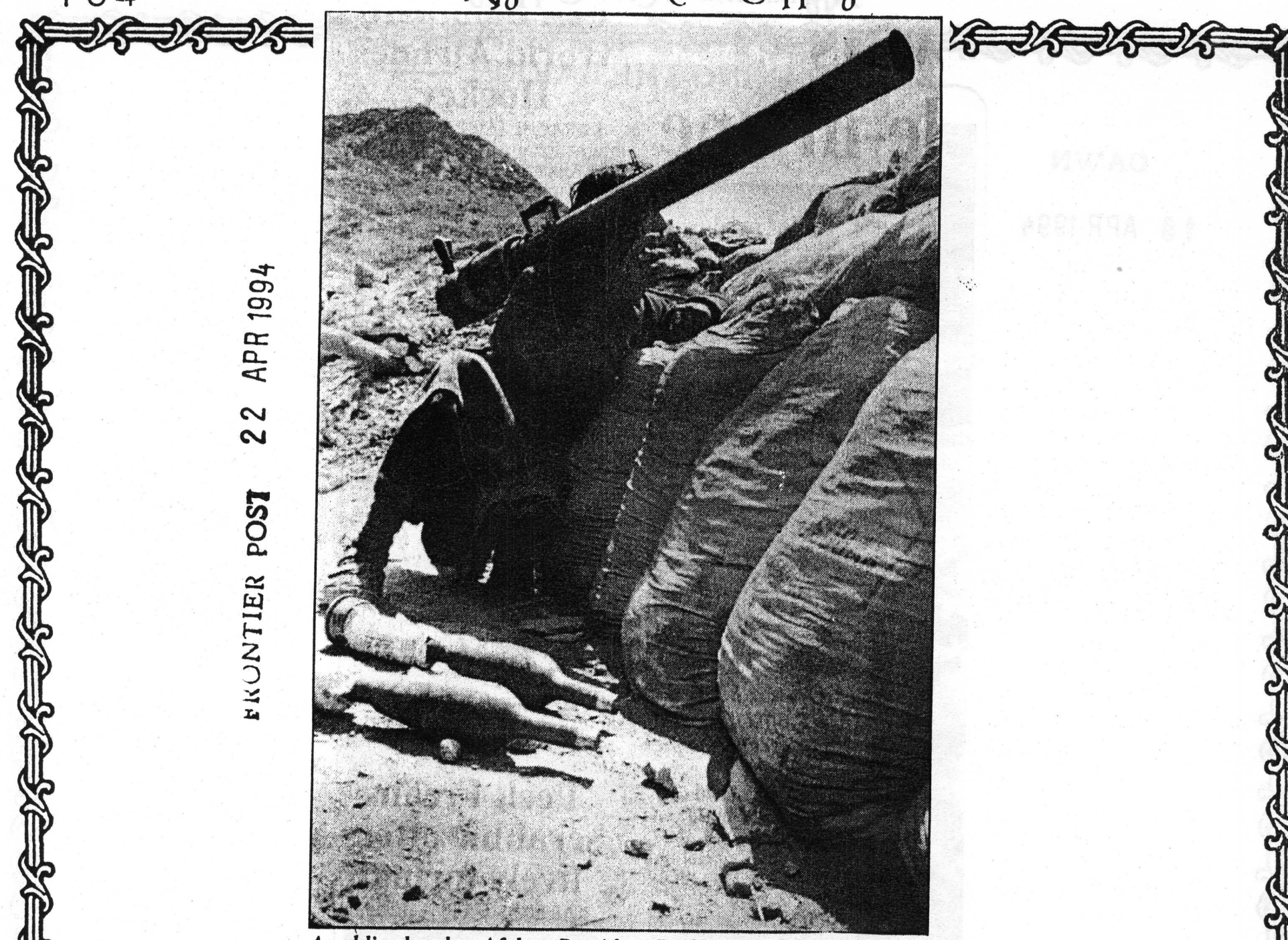

A soldier loyal to Afghan President Burhanuddin Rabbani with a Russian-made $82 \mathrm{~m}$ recoilless rifle peers over a frontline trench in the Kabul Zoo during fighting against the Shiite Hezb-i-Wahdat faction Thursday in which 140 civilians were wounded and an unknown number were killed-AFP photo

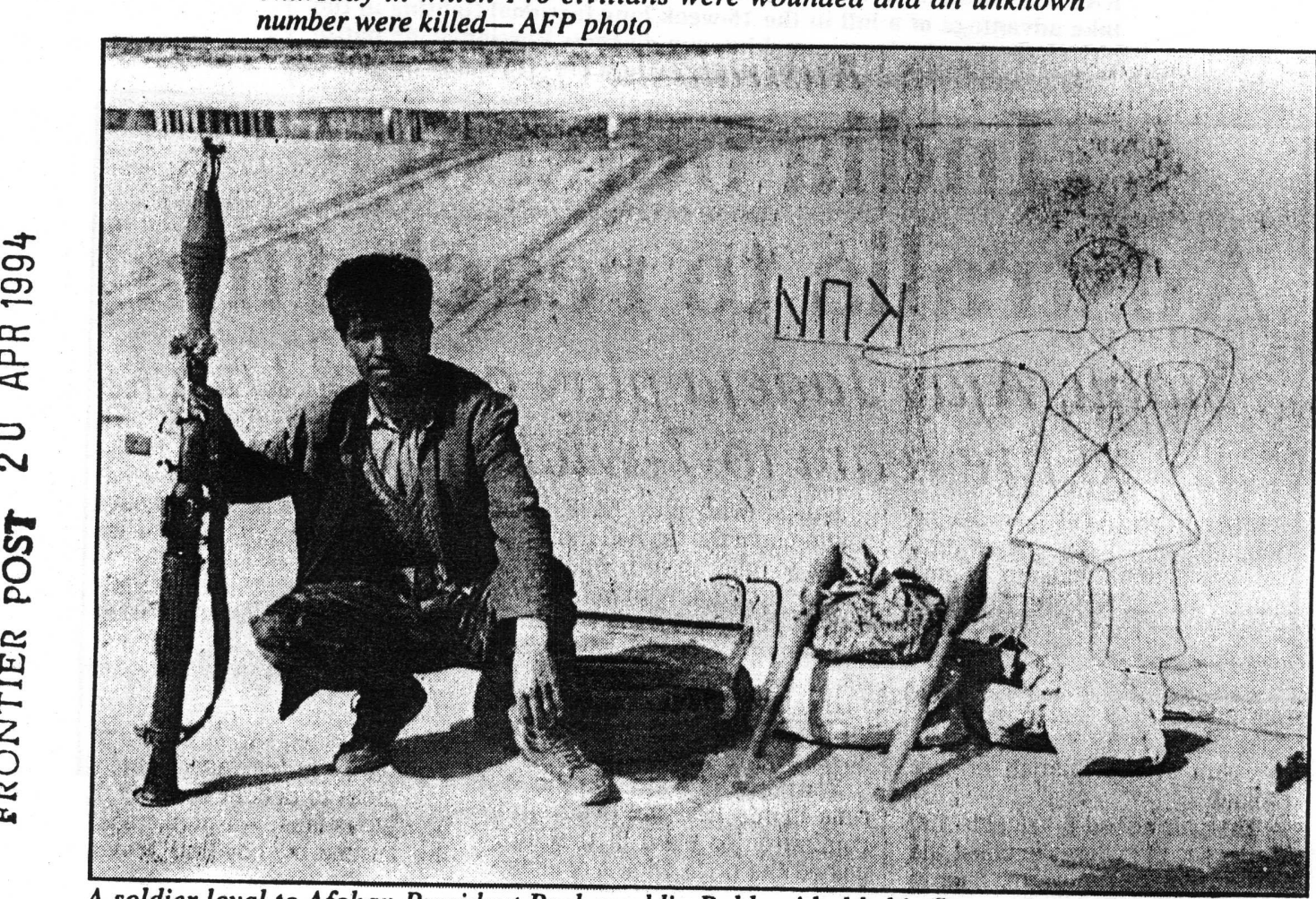

A soldier loyal to Afghan President Burhanuddin Rabbani holds his flower-decorated RPG-7 antitank rocket launcher while a wrought iron helper is positioned next to him at an unusual west Kabul checkpoint on Tuesday during a lull in the 16-week long factional fighting. -AFP photo 


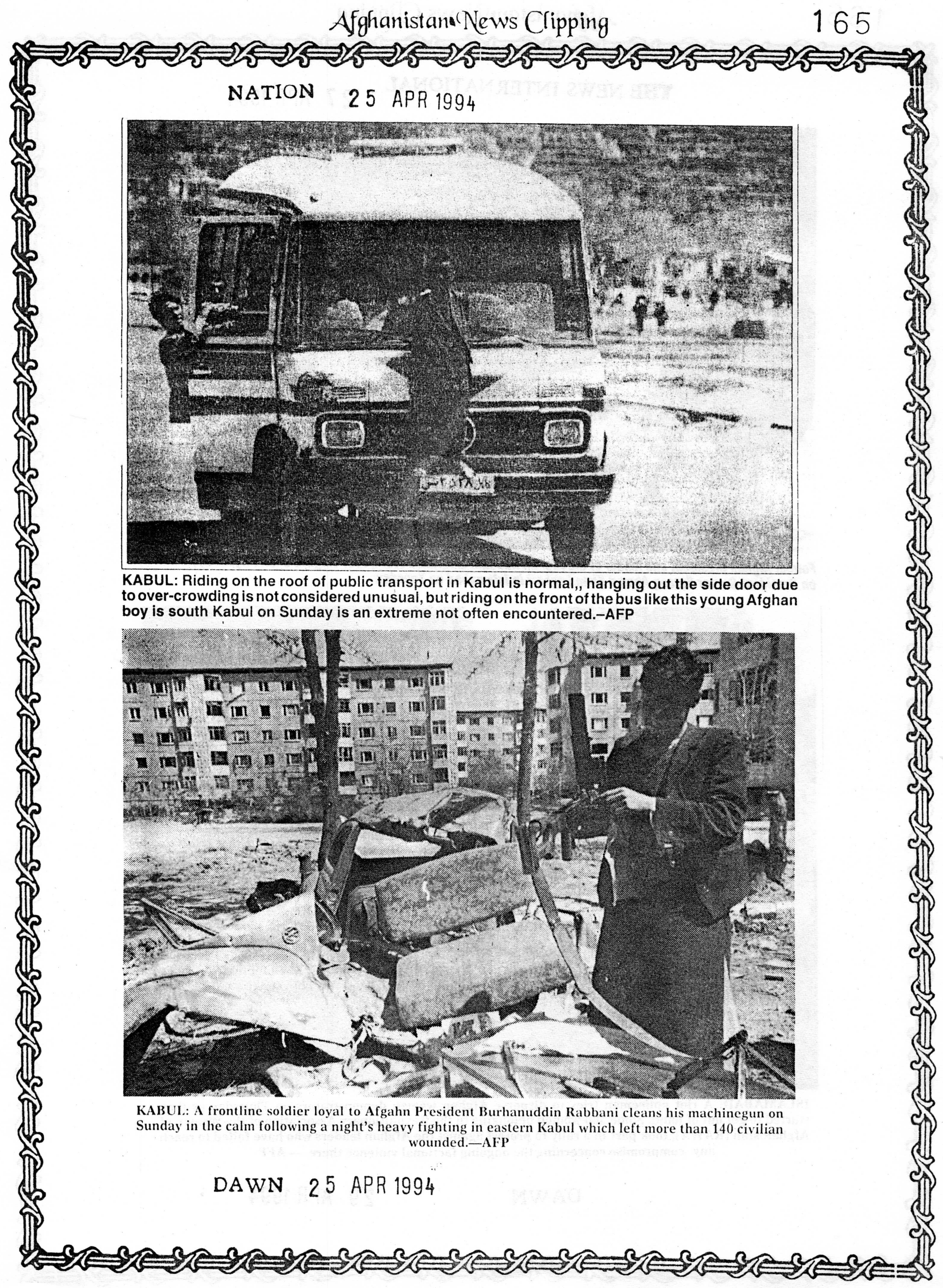




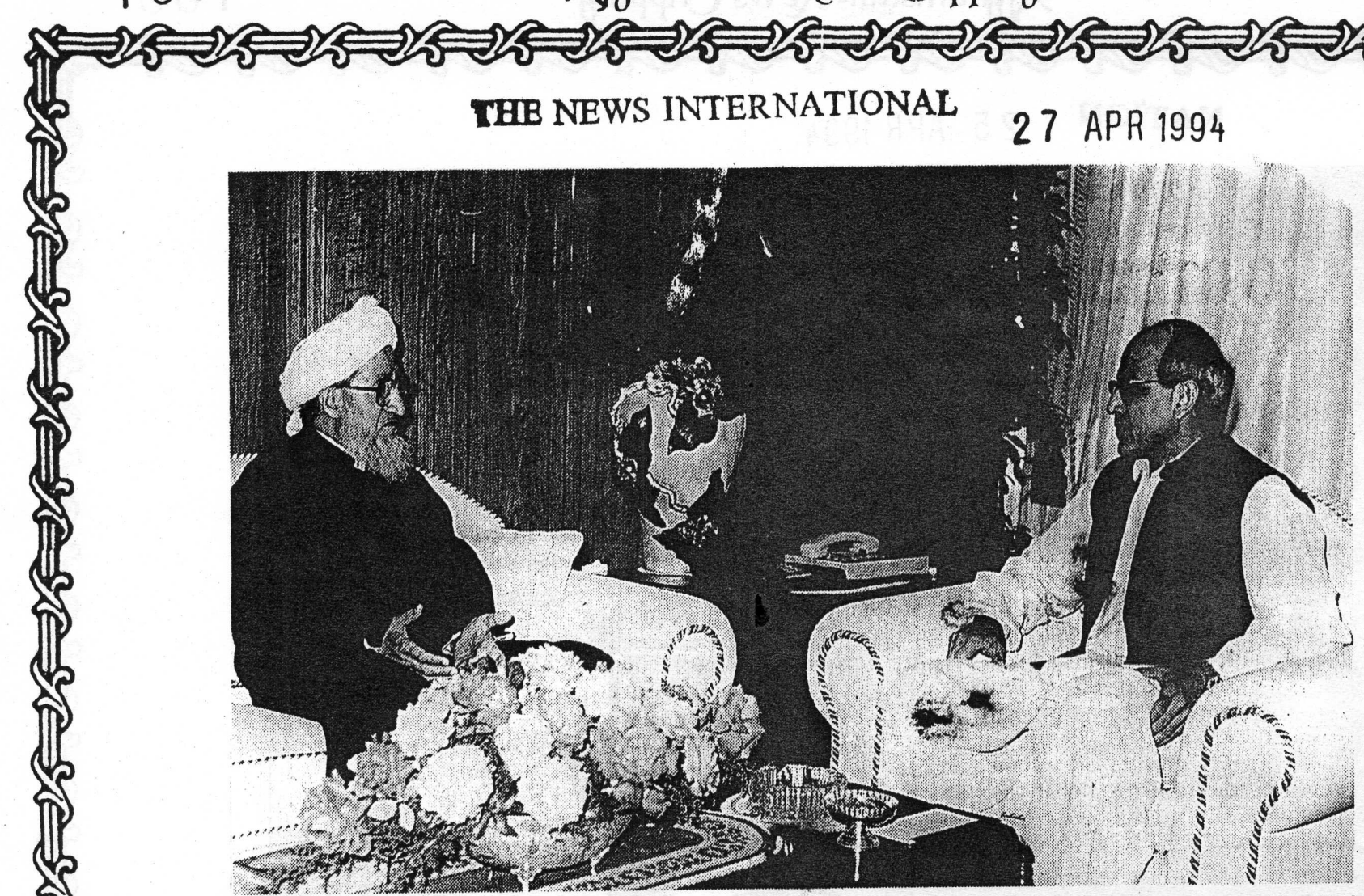

Former Afghan president and leader of the Afghan National Liberation Front, Prof Sibghat Ullah Mujaddedi, calle" on President Sardar Farooq Ahmed Khan Leghari in Islamabad on Tuesday.

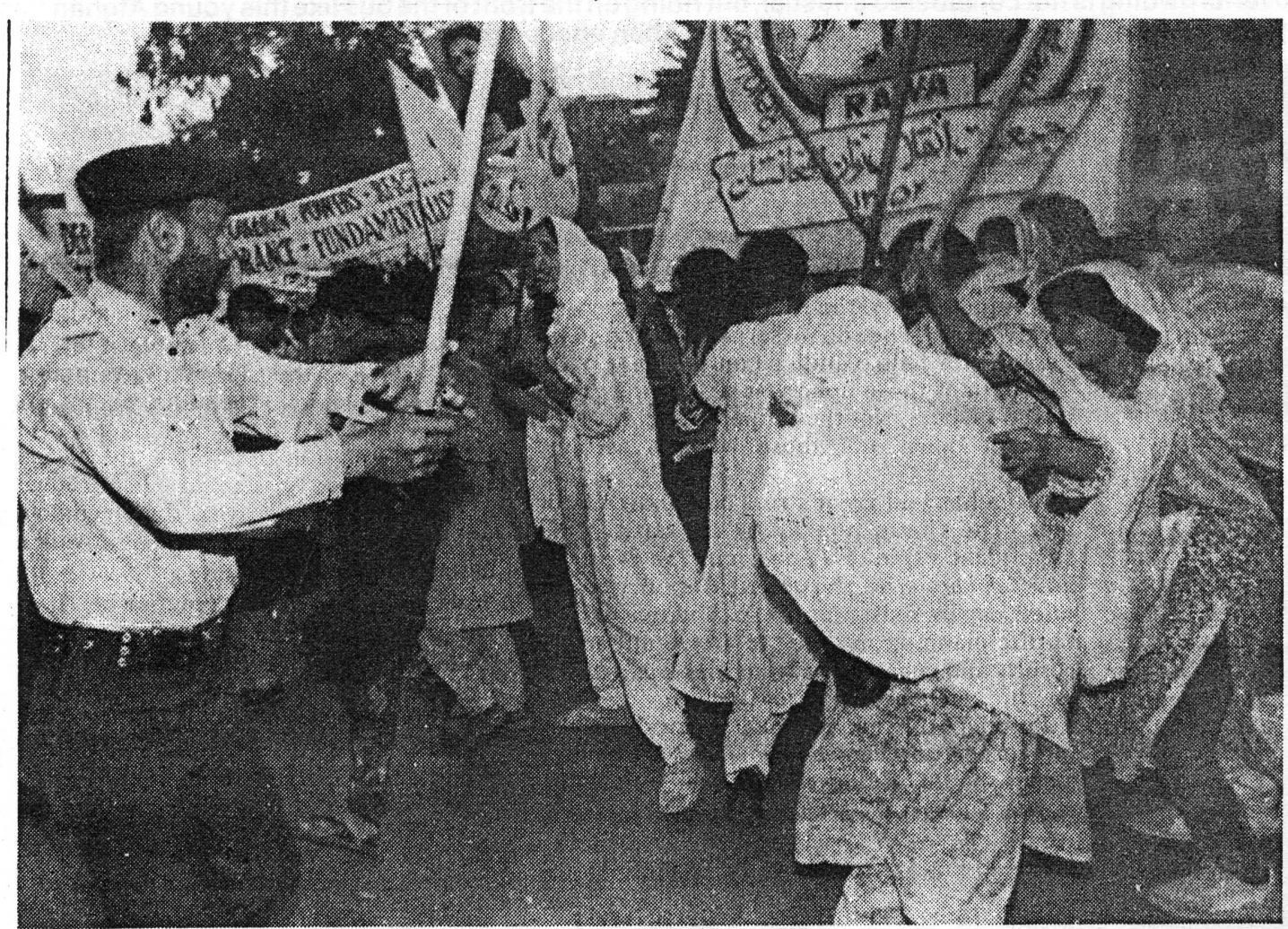

ISLAMABAD: A riot policeman tries to disperse Afghan women demonstrators on Thursday as they started to get out of hand. Some 300 women belonging to the Revolutionary Association of the Women of Afghanistan (RAWA), took part in a rally to protest against the Afghan leaders who have failed to reach any compromise concerning the ongoing factional violence there. - AFP 


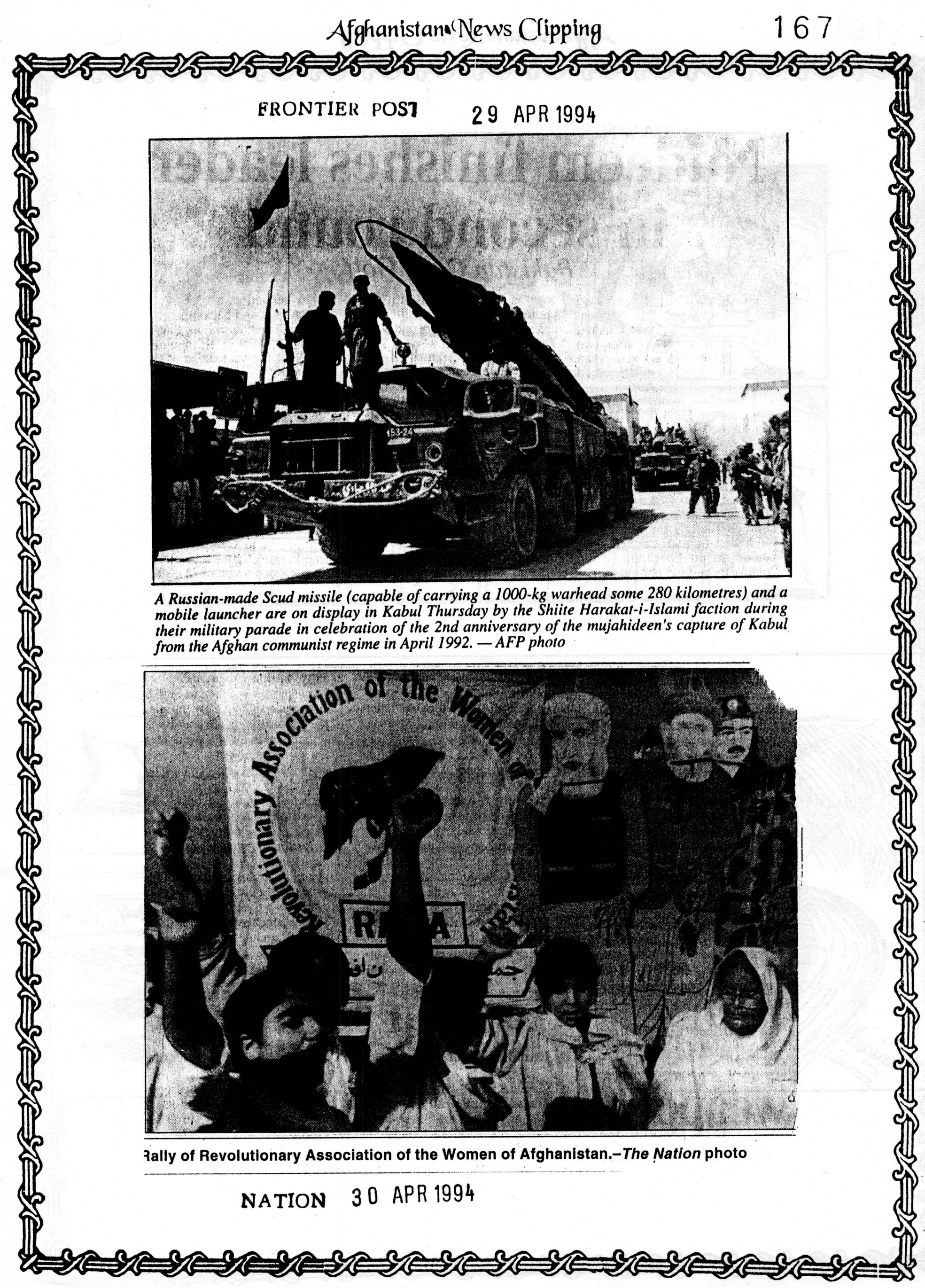


$168 \quad$ Afghanistana'News Clipping
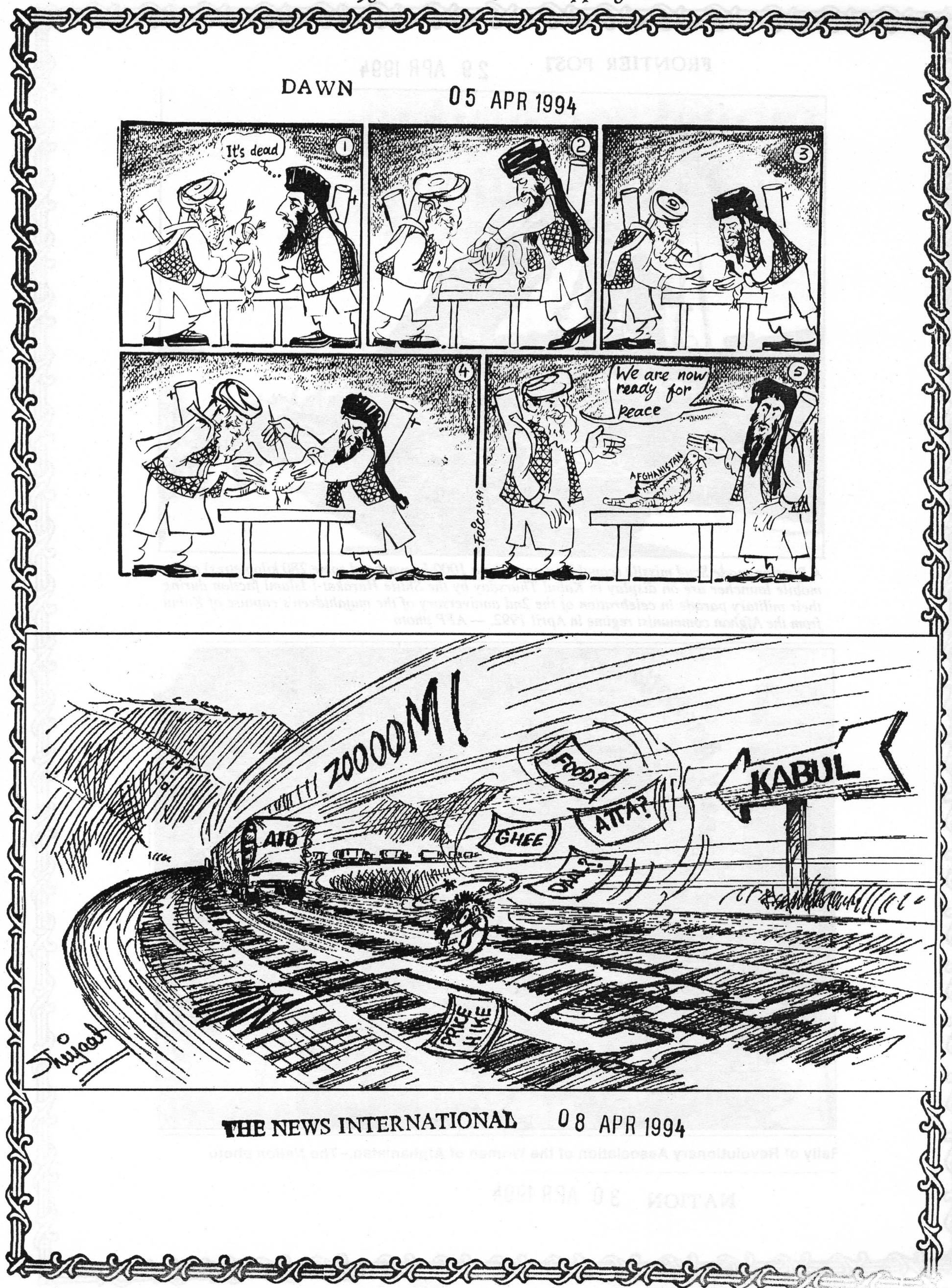
Afghanistana"News Clipping

169

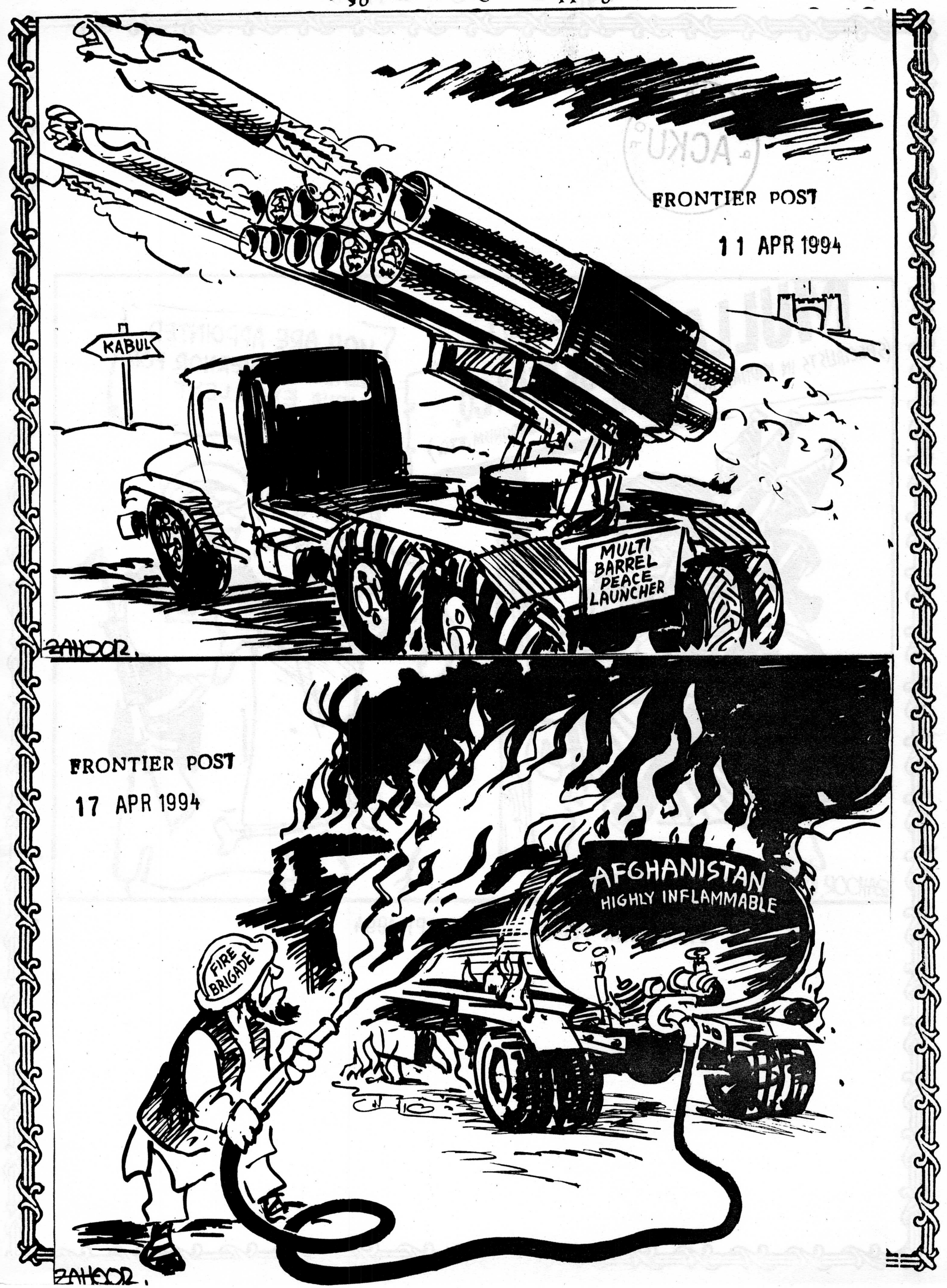


1970<smiles>c1ccccc1</smiles>

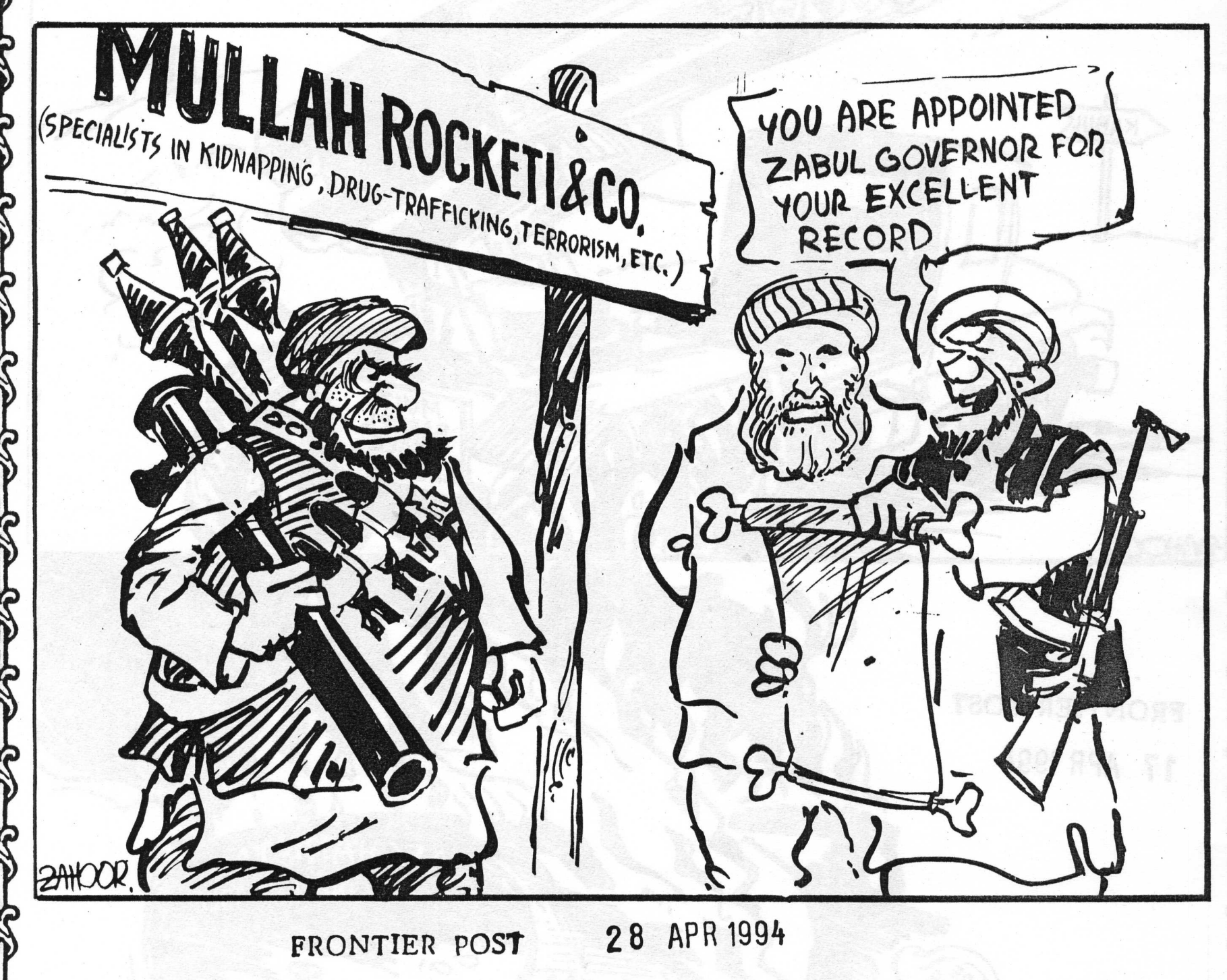

